KATIA MARIA ROBERTO DE OLIVEIRA KODAMA

\title{
Iconografia como processo comunicacional da Folia de Reis: o avatar das culturas subalternas
}

\author{
Tese apresentada ao Programa de Pós- \\ Graduação em Ciências da Comunicação da \\ Escola de Comunicações e Artes da \\ Universidade de São Paulo para obtenção do \\ título de Doutor em Ciências da Comunicação. \\ Área de Concentração: Interfaces Sociais da \\ Comunicação \\ Orientadora: Profa. Dra. Maria Nazareth \\ Ferreira
}


AUTORIZO A REPRODUÇÃO E DIVULGAÇÃO TOTAL OU PARCIAL DESTE TRABALHO, POR QUALQUER MEIO CONVENCIONAL OU ELETRÔNICO, PARA FINS DE ESTUDO E PESQUISA, DESDE QUE CITADA A FONTE.

\section{Catalogação na Publicação}

Escola de Comunicações e Artes da Universidade de São Paulo

Kodama, Kátia Maria Roberto de Oliveira.

Iconografia como processo comunicacional da Folia de Reis: o avatar das culturas subalternas / Kátia Maria Roberto de Oliveira Kodama. - - São Paulo: K.M.R.O. Kodama, 2009.

299 p. : il.

Tese (Doutorado) - Departamento de Ciências da Comunicação/ Escola de Comunicações e Artes/USP.

Orientadora: Profa. Dra. Maria Nazareth Ferreira.

Bibliografia

1. Festas populares - Região de Ourinhos (SP) - Brasil 2. Festas religiosas Brasil 3. Cultura popular - Ourinhos (SP) - Brasill 4. Folia de Reis - Ourinhos (SP) - Brasil 5. Processos comunicacionais - cultura subalterna I. Ferreira, Maria Nazareth II. Título 
FOLHA DE APROVAÇÃO

Katia Maria Roberto de Oliveira Kodama

Iconografia como processo comunicacional da Folia de Reis: o avatar das culturas subalternas

Tese apresentada ao Programa de PósGraduação em Ciências da Comunicação da Escola de Comunicações e Artes da Universidade de São Paulo para obtenção do título de Doutor em Ciências da Comunicação. Área de Concentração: Interfaces Sociais da Comunicação

Orientadora: Profa. Dra. Maria Nazareth Ferreira

Aprovada em:

\section{BANCA EXAMINADORA}

Prof $^{\mathrm{a}} \mathrm{Dr}^{\mathrm{a}}$ : Maria Nazareth Ferreira

Instituição: ECA/USP

Assinatura:

Prof. Dr.:

Instituição:

Assinatura:

Prof. Dr.:

Instituição:

Assinatura:

Prof. Dr.:

Instituição:

Assinatura:

Prof. Dr.:

Instituição:

Assinatura: 
Dedico este trabalho para os três reis de minha vida:

Carlos, Otávio e Flávio 


\section{AGRADECIMENTOS}

A Deus, em primeiro lugar, e aos Santos Reis.

A minha orientadora Maria Nazareth Ferreira, que se dedicou com carinho e respeito ao meu trabalho.

Ao meu marido e meus filhos, pelo amor, força e paciência.

Ao Museu de Arte Primitiva José Nazareno Mimessi, por ter cedido fotos das obras de seu acervo para ilustrar este trabalho.

Ao CEDAP - Unesp de Assis, por disponibilizar o arquivo de José Nazareno Mimessi.

Aos Foliões de todas as Folias pesquisadas, pela acolhida e prontidão em responder minhas indagações, mesmo, muitas vezes, parecendo óbvias demais para eles, e pela sinceridade e acolhimento.

Enfim, a todos, e foram muitos, que colaboraram para a realização deste trabalho. 
Os devotos do Divino vão abrir sua morada

Pra bandeira do Menino ser bem-vinda, ser louvada, ai, ai

Deus nos salve esse devoto pela esmola em vosso nome

Dando água a quem tem sede, dando pão a quem tem fome, ai, ai

A bandeira acredita que a semente seja tanta

Que essa mesa seja farta, que essa casa seja santa, ai, ai

Que o perdão seja sagrado, que a fé seja infinita

Que o homem seja livre, que a justiça sobreviva, ai, ai

Assim como os três Reis Magos que seguiram a estrela guia A bandeira segue em frente atrás de melhores dias

No estandarte vai escrito que ele voltará de novo

E o Rei será bendito, ele nascerá do povo, ai, ai

Bandeira do Divino. Ivan Lins e Vitor Martins. 


\section{RESUMO}

KODAMA, K. M. R. O. Iconografia como Processo Comunicacional da Folia de Reis: o avatar das culturas subalternas. 2009. 299 p. Tese (Doutorado). Escola de Comunicação e Artes, Universidade de São Paulo, 2009.

A pesquisa aqui apresentada é um estudo da Folia de Reis do bairro rural de Ribeirão Grande, em Ourinhos/SP e das cidades vizinhas. Trata-se também das mesmas festas retratadas nas pinturas do acervo do Museu de Arte Primitiva de Assis "José Nazareno Mimessi", como produto das culturas populares subalternas. Analisa suas características estéticas e simbólicas e como seus elementos fundantes permanecem, suas possíveis descaracterizações e os processos de assimilação e acomodação das diferentes culturas que nelas transitam, com vistas a ampliar as conceituações sobre as manifestações das culturas populares do país e colaborar para ampliar a compreensão da realidade na qual estamos inseridos. Por outro lado, este trabalho pretende, ainda, examinar a festa popular estudada como significativo instrumento de comunicação que ultrapassou os limites do passado, compreender como acontecem no presente e projetar perspectivas para a edificação da identidade cultural das culturas subalternas, no futuro. Também pretende apresentar as representações imagéticas das culturas populares subalternas como elementos de sustentação das tradições mantidas pela oralidade, assim como registros e documentos para compreender como se dá a acomodação e reestruturação das novas informações e influências trazidas pelos processos comunicacionais da contemporaneidade.

Palavras-chave: comunicação subalterna; festas populares; Folia de Reis; representações imagéticas; cultura popular subalterna. 


\begin{abstract}
Kodama, K. M. R. O. Iconography as communicational process of Epiphany Celebration: the avatar of subaltern cultures. 2009. 299 p. Tese (Doutorado). Escola de Comunicação e Artes, Universidade de São Paulo, 2009.

This research is a study of the Epiphany Celebrations performed in the rural district Ribeirão Grande, in Ourinhos/SP, and neighboring cities. The same celebrations portrayed in the paintings of the Museu de Arte de Assis "José Nazareno Mimessi" collection are studied as well, as a product of subaltern cultures. It analyzes their esthetic and symbolic characteristics and how their founding elements remain: their likely decharacterization and also the assimilation and accommodation processes of the cultures which transit in them. Aiming to broaden the concept spectrum on the country's popular cultural manifestations as well as to contribute to widen the understanding of the reality in which we are inserted. On the other, this work expects, also, to examine this celebration as a significant communication tool which has surpassed the boundaries of the past, to understand how they occur in the present and to draw perspectives on the edification of the cultural identity of subaltern cultures, in the future. It also intends to present subaltern cultures imagetic representations as sustaining elements of traditions which are held on through orality as well as records and documents, in order to understand how the accommodation and restructuring of new information and influences brought on by contemporary communicational processes take place.
\end{abstract}

Key Words: subaltern communication; popular parties; Epiphany Celebration; imagetic representations; subaltern popular culture. 


\section{LISTA DE IMAGENS}

Imagem 3.1: Les Très Riches Heures du Duc de Berry

Imagem 3.2: Pieter Brugel. A dança dos camponeses. Kunsthistorisches

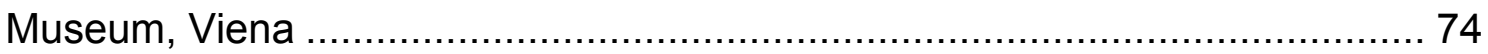

Imagem 3.3: Folia de Reis na Fazenda Rainha da Paz ............................... 84

Imagem 3.4: Teto de igreja barroca ....................................................... 94

Imagem 3.5: Detalhe de Bandeira do Divino .............................................. 94

Imagem 3.6: Palma de prata barroca ..................................................... 95

Imagem 3.7: Objeto que compõe a figura de lemanjá............................... 95

Imagem 3.8: Porta Estandarte de Maracatu ............................................. 95

Imagem 3.9: Tapete da Procissão de Corpus Christi .................................. 95

Imagem 3.10: Caboclo de lança de Maracatu Rural ................................ 96

Imagem 3.11: Procissão de Círio de Nazaré, Belém/PA, 1986 ..................... 96

Imagem 3.12: Nossa Senhora do Carmo e detalhe do manto ......................... 97

Imagem 3.13: Carnaval Porta-Bandeira e detalhe da saia.......................... 97

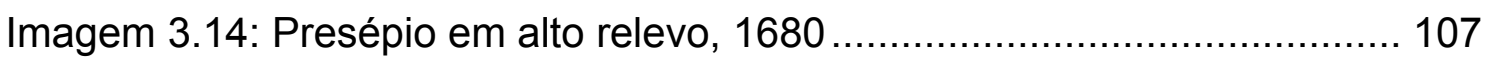

Imagem 3.15: Vitral com motivo de presépio, 1846. Catedral de Colônia -

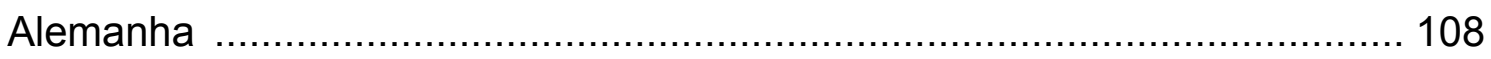

Imagem 3.16: Catedral de Colônia, Alemanha ..................................... 113

Imagem 3.17: Vista lateral e frontal do Relicário dos Reis Magos, Catedral da

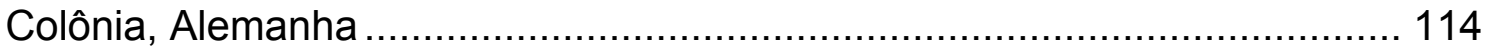

Imagem 3.18: Forte dos Reis Magos, Natal/RN .................................. 120

Imagem 5.1: Dila. Festa no quintal. óleo s/tela. 60x80 cm. 1996 ................ 208

Imagem 5.2: Miranda. Plantação de cana-de-açúcar. óleo s/ eucatex

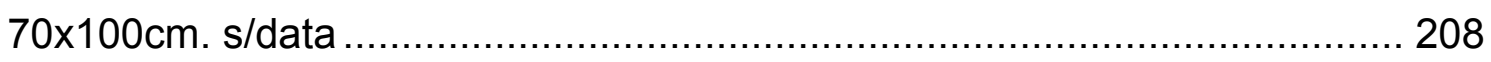

Imagem 5.3: Miranda. O tráfego. óleo s/eucatex 70x100 cm. $1974 \ldots \ldots \ldots \ldots . . .209$

Imagem 5.4: Rosina Becher do Valle. Festa Junina. óleo s/tela 40x50 cm.1993

Imagem 5.5: DSC06415. Artista: Adão Silvério. Título: Folia de Reis. Técnica: acrílica sobre tela. Dim: $30,0 x$ 40,00 ............................................. 216

Imagem 5.6: DSC06412. Artista: Euridyce. Título: Povo a caminho de Jerusalém. Técnica: Bico de pena. Dim: 51,5x40,0 ............................ 217 
Imagem 5.7: DSC06409. Artista: Enéias Tavares Santos. Título: Presépio. Técnica: Xilogravura popular. Dim: 20,0x15,00 ................................... 217 Imagem 5.8: DSC06406. Artista: Omar Souto. Título: Presépio. Técnica: óleo

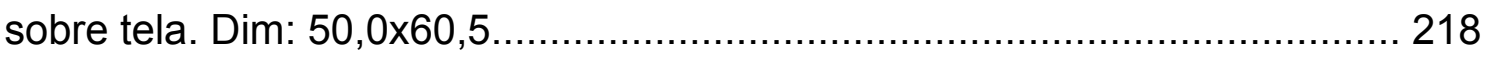
Imagem 5.9: DSC06400. Artista: Semearte. Técnica: mista ........................ 218 Imagem 5.10: DSC06393. Artista: Euridyce. Título: A sagrada família. Técnica: Bico de pena Dim: 40,0x51,5 ............................................ 219 Imagem 5.11: DSC06389. Artista: Enéias Tavares Santos. Título: Reisado. Técnica: Xilogravura popular. Dim: 20,0x15,0 .......................................... 219 Imagem 5.12: DSC06391. Artista: J.Rissin. Título: Figura de Reisado. Técnica:


Imagem 5.13: DSC06386. Artista: Euridyce. Título: O menino Jesus. Técnica:

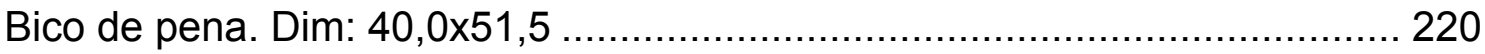
Imagem 5.14: DSC06384. Artista: Euridyce. Título: Gaspar, Melchior e Baltazar. Técnica: Bico de pena. Dim: 51,5x40,0 ................................... 221 Imagem 5.15: DSC06382. Artista: Edgar Bastos. Título: Reisado. Técnica: óleo sobre papel canson. Dim: 23,0x32,0 ............................................... 221 Imagem 5.16: Título: Folia de Reis - Folclore Brasileiro. Autora: Rosina

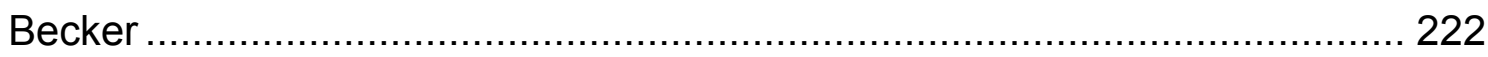
Imagem 5.17: Folia de Reis. Autor: Dag França ....................................... 222 


\section{LISTA DE FOTOS}

Foto 3.1: Detalhe da fachada da Igreja da Ordem Terceira de São Francisco,

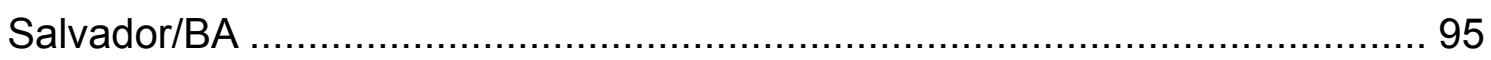

Foto 3.2: Encontro de Folia de Reis, Assis/SP ........................................... 99

Foto 3.3: Presépio para Receber a Bandeira de Reis .................................. 107

Foto 4.1: Embaixador tocando Viola. Companhia dos Faceiros..................... 131

Foto 4.2: Gerente da Companhia dos Faceiros, à esquerda na foto.............. 133

Foto 4.3: Festeira para 2009 de Ourinhos/SP ............................................ 134

Foto 4.4: Galpão onde é realizada a Festa de Reis, no bairro de Ribeirão

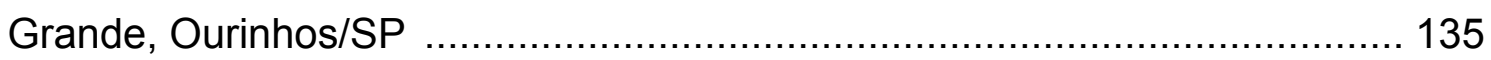

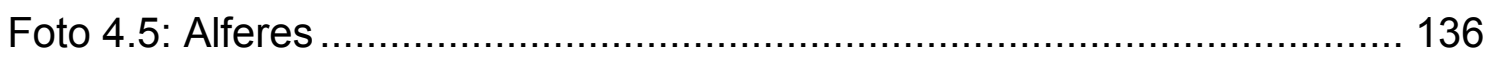

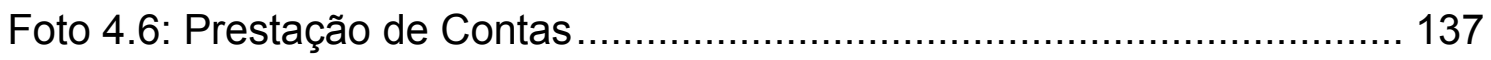

Foto 4.7: Músicos da Companhia dos Faceiros ........................................... 138

Foto 4.8: Músicos da Companhia Anhumas.............................................. 138

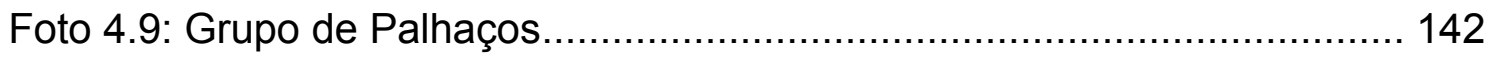

Foto 4.10: Foliões em Festa de Reis..................................................... 144

Foto 4.11: Bandeiras do Encontro de Folias de Assis/SP ............................. 146

Foto 4.12: Bandeira centenária de Cândido Mota/SP .................................. 148

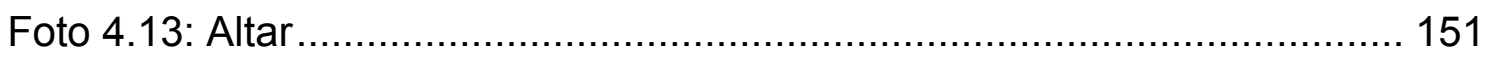

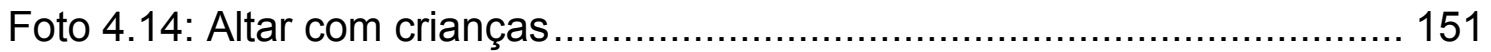

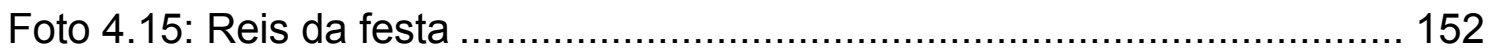

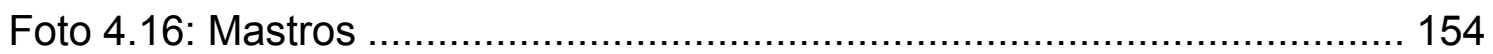

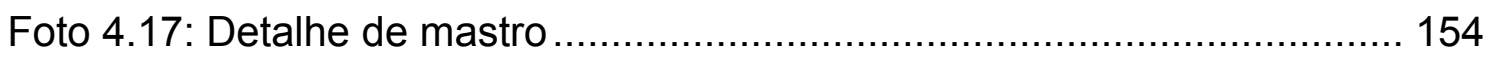



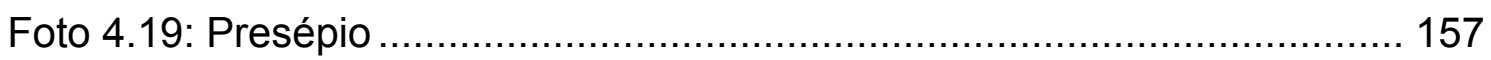

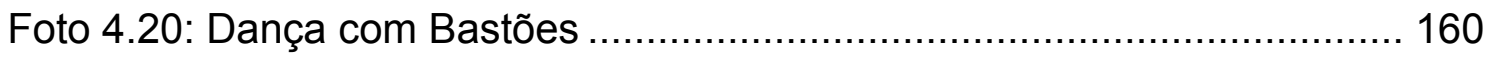

Foto 4.21: Palhaços com Bastões ............................................................ 160

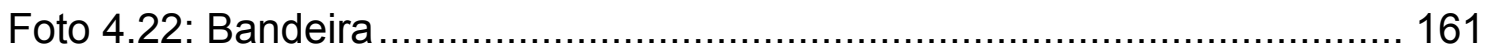

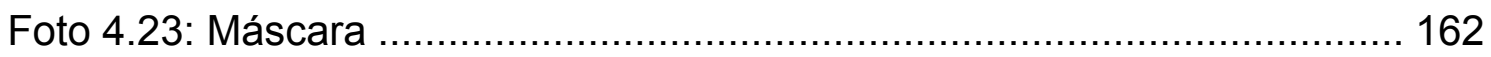

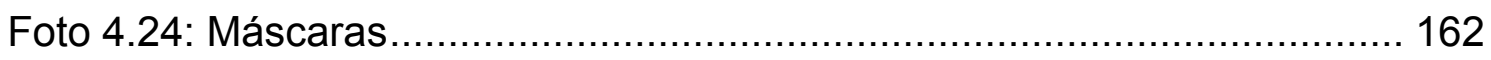

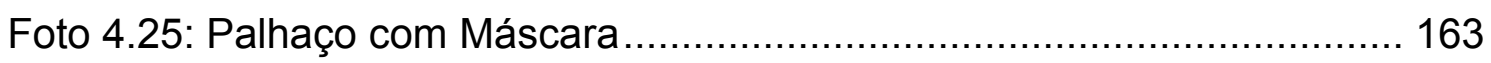



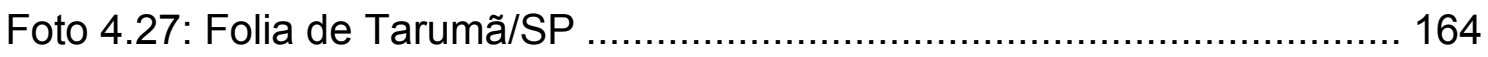


Foto 4.28: Folia de José Moraes, Assis/SP.

Foto 4.29: Cantoria de entrada, Cia. Anhumas - Palmital/SP.

Foto 4.30: Almoço da Festa de Palmital/SP

Foto 4.31: Cantoria em agradecimento de almoço

Foto 4.32: Oração em agradecimento a almoço

Foto 4.33: Mutirão para preparar o almoço, Palmital/SP 174

Foto 4.34: Voluntários lavando batatas, Palmital/SP 174

Foto 4.35: Sacas de batatas e cebolas doadas para almoço da Festa de Reis Palmital/SP

Foto 4.36: Participação de voluntários de todas as idades - Palmital/SP. 175

Foto 4.37: Preparo de um dos pratos servidos no almoço da festa de Palmital/SP 176

Foto 4.38: Detalhe do tacho de preparo de carne com batatas - Palmital/SP 176

Foto 4.39: Voluntários escolhendo feijão - Palmital/SP 176

Foto 4.40: Mesas montadas para Almoço - Palmital/SP 176

Foto 4.41: Carne preparada para almoço da festa de Palmital/SP 177

Foto 4.42: Cortando pedaço de fita da Bandeira - Palmital 178

Foto 4.43: Público da Festa de Palmital/SP 180

Foto 4.44: Estacionamento - Festa de Folia de Reis Palmital/SP 180

Foto 6.1: Bandeira da Folia de Ribeirão Grande, Ourinhos/SP 228

Foto 6.2: Bairro de Ribeirão Grande, Ourinhos/SP 228

Foto 6.3: Companhia Mensageiros da Paz. Encontro de Folias de Assis/SP 250 


\section{LISTA DE MAPAS}

Mapa 2.1: Carta do progresso dos trabalhos da comissão Geográfica e Geológica - Província de São Paulo 35 Mapa 2.2: A penetração e a Posse dos mineiros no vale do Paranapanema em meados do século XIX 36 Mapa 2.3: A penetração e a Posse dos mineiros no vale do Paranapanema em meados do século XIX 37

Mapa 2.4: Linhas Ferroviárias de SP, em 1987 45

Mapa 2.5: Espacialidade das Ferrovias e Rodovias que cortam Ourinhos/SP 50 Mapa 2.6 Localização das Terras Indígenas no Estado de São Paulo 62 


\section{LISTA DE ABREVIATURAS E SIGLAS}

AECO

AERO

$B A$

CEDAP

Cia.

$\mathrm{COHAB}$

D.

d.C.

Ed.

FAPI

IBGE

Is.

ISA

MAE

MASP

MPB

Mt.

PCNs

PR

RN

SBPC

SP

Telesp

UNESP

USP
Associação Esportiva e Cultural de Ourinhos

Associação dos Engenheiros de Ourinhos

Estado da Bahia

Centro de Documentação e Apoio à Pesquisa

Companhia

Conjunto Habitacional

Dom

Depois de Cristo

Editora

Feira Agropecuária e Industrial de Ourinhos

Instituto Brasileiro de Geografia e Estatística

Isaías

Instituto Sócio-Ambiental

Museu de Arqueologia e Etnologia

Museu de Artes de São Paulo

Música Popular Brasileira

Mateus

Parâmetros Curriculares Nacionais

Estado do Paraná

Estado do Rio Grande do Norte

Sociedade Brasileira para o Progresso da Ciência

Estado de São Paulo

Telecomunicações de São Paulo

Universidade Estadual Paulista

Universidade de São Paulo 
SUMÁRIO

1 INTRODUÇÃO E APONTAMENTOS TEÓRICO-METODOLÓGICOS ......... 17

2 UMA HISTÓRIA FEITA DE OUTRAS HISTÓRIAS …............................. 32

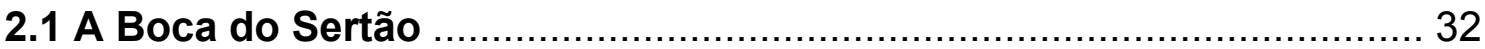

2.2 As Linhas da Estrada de Ferro como Veículos de Comunicação ........ 42

2.3 No Fim da Linha, a Cidade de Ourinhos ....................................... 46

2.4 Os Povos Originários - Suprimidos e Esquecidos .......................... 55



2.6 Os Interesses Hegemônicos e os Subalternos ................................. 67

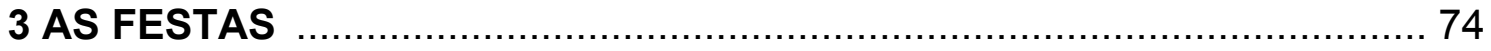

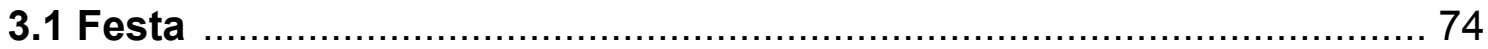

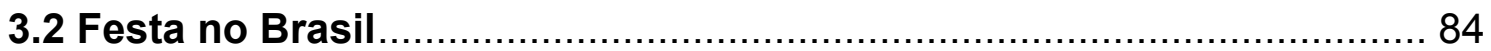

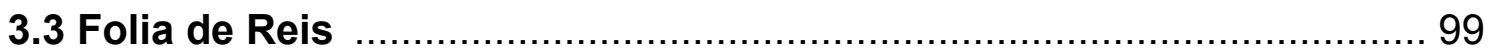

3.3.1 A origem das Folias de Reis.................................................. 101

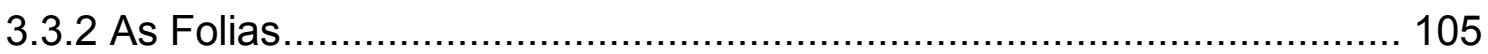

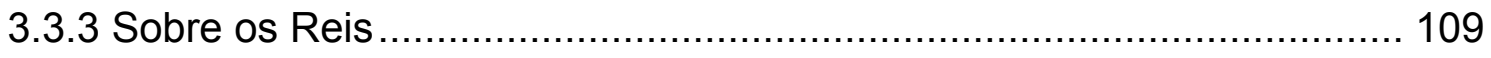

3.3.4 Folia de Reis no Brasil............................................................. 117

4 ORGANIZAÇÃO E ELEMENTOS DAS FOLIAS DE REIS ..................... 130

4.1 Atribuições e Funções dos Participantes das Folias de Reis ........... 130

4.2 Elementos Iconográficos das Folias de Reis .............................. 145

4.3 Os Diferentes Rituais da Folia de Reis ....................................... 165

5 O REGISTRO DAS CULTURAS SUBALTERNAS NA ARTE DOS

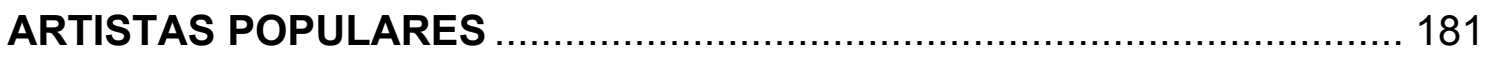

5.1 O Museu de Arte Primitiva de Assis e sua Arte Desconhecida ........ 181

5.2 Apontamentos sobre Teoria para as Artes Populares ..................... 195

5.3 Imagens que contam das Festas Populares ................................. 210

5.4 O Artista-Tradutor do Viver em Imagens .................................... 213

6 O AVATAR PRESENTE NA ICONOGRAFIA COMO PROCESSO COMUNICACIONAL DE PERMANÊNCIA DA FOLIA DE REIS ................. 223

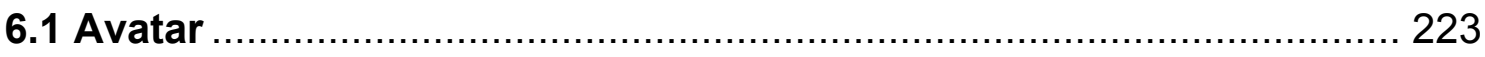

6.2 Manifestações Iconográficas das Folias de Reis .......................... 230

6.2.1 A espacialidade como iconografia ................................................ 232 
6.2.2 Performance das Folias de Reis como iconografia

6.3 Os Processos Comunicacionais nas Folias de Reis

7 CONCLUSÕES PRELIMINARES

ANEXO A - Transcrição das cantorias da Cia. dos Faceiros, Palmital/SP 266

ANEXO B - Coroação de um Rei Negro

ANEXO C - Cópia de Documentos do Arquivo de José Nazareno Mimessi

- CEDAP, Assis/SP 


\section{INTRODUÇÃO E APONTAMENTOS TEÓRICO-METODOLÓGICOS}

Esta pesquisa nasceu da necessidade de compreender e contribuir para ampliar o referencial teórico das Ciências Sociais, através de um objeto de estudo inserido em uma realidade concreta. Portanto, o método dialético foi a opção para analisar as Festa Populares - Folia de Reis - já que elas, por si só, deixam transparecer uma dinâmica de constante evolução e adaptação apresentada no tempo e no espaço. Também esta metodologia sustentará as análises do viver que desencadeiam as relações sociais, culturais, políticas e espirituais das comunidades, entendendo-se que a espiritualidade dos grupos sociais está sujeita aos modos de produção das mesmas. Parte ainda, do pressuposto que a produção, a troca, a circulação dos bens e produtos sustentam as organizações sociais nos diferentes momentos da história, assim como na atualidade, desencadeiam, concomitantemente, a divisão dos homens em camadas ou extratos sociais, determinado pelo o quê e como a sociedade produz e pelo modo de modificar e intercambiar suas produções e suas manifestações culturais. Este processo é visto como um procedimento filosófico e compartilhado com Ferreira:

\footnotetext{
Nesse contexto qual o papel da filosofia? O papel da filosofia é reunir o que está separado, fragmentado, dando um sentido de totalidade e de unidade ao homem e suas ações. Sem a interferência da filosofia, o mundo cognoscível seria um conjunto de forma de parcialidades, onde o conhecimento científico não teria a visibilidade necessária para gerar transformação. (FERREIRA, 2006, p.35).
}

Assim sendo, os estudos que serão apresentados deverão sempre levar em consideração que os pressupostos teóricos utilizados deverão contribuir para ampliar as reflexões acadêmicas e serem apropriados e utilizados pelos geradores dos objetos estudados. 
Neste trabalho, respeitando os pressupostos teóricos enunciados, far-se-á uso de diferentes teorias que estão “isoladas e dissociadas", mas que mantêm os princípios de uma "unidade integradora" entre "teoria e método" (FERREIRA, 2006). Para atingir esses objetivos, serão necessárias a utilização e integração de diferentes Ciências como História, Sociologia, Antropologia, Ciências da Comunicação, Estética da Arte e Filosofia, resultando, como preconiza Ferreira, no uso da interdisciplinaridade e interproblematização, que fazem parte do processo investigativo das Ciências Sociais, que é ao mesmo tempo: "unitária - universal e específica - particular" (FERREIRA, 2006).

Logo, levantamentos históricos serão necessários para compreender a festa como um objeto da constituição das relações humanas e formação social da brasilidade e da regionalidade, assim como as manifestações artísticas que delas se originam.

O diálogo com diferentes ciências e com diferentes registros das festas - Folia de Reis - será exposto neste trabalho para demonstrar e sustentar as indagações que este estudo propõe:

As manifestações imagéticas e iconográficas podem ser o elemento mantenedor e sustentador de permanência das festas populares Folia de Reis - e, portanto, as portadoras e depositárias do ethos das festas populares das culturas subalternas? Dito de outro modo, esta permanência pode ser ancorada nos elementos visuais das festas, como as artes plásticas ou as representações visuais que dão sentido a essas festas?

Nesse sentido, para abarcar toda a dinâmica de multiculturas e interculturas presentes nas festas, far-se-á uso do termo de origem gramsciana 
de culturas subalternas ou cultura das classes subalternas. Ortiz (1985) infere que "o pensador italiano Antônio Gramsci, ao criar esta expressão, empregavaa no sentido de diferenciar patrimônio cultural do povo da cultura oficial" denominada também de cultura dominante, cultura das classes dominantes ou hegemônicas. Nessa perspectiva, investigar as festas populares é destacar a necessidade da preservação das identidades culturais do país e das diferentes regiões que o compõe, como mecanismos de transformação e valorização dos povos do país e da América Latina, constantemente ofuscados pelas culturas hegemônicas oriundas do neoliberalismo ou "novo colonialismo".

Por conseguinte, o caminho traçado pelo método dialético, segundo Ferreira, pode ser dividido em três momentos de compreensão que nortearão este trabalho:

“a) gnosiologia, ou teoria do conhecimento. É o estudo da origem, organização e validade do mundo das idéias, enquanto representação das coisas objetivamente reais [...]" (FERREIRA, 2006, p.69) que se dará através dos estudos, de textos, livros e dos levantamentos bibliográficos feitos para subsidiar a compreensão do objeto do estudo.

“b) lógica dialética, que estuda a estrutura e o funcionamento dos processos segundo os quais as idéias se relacionam umas às outras em operações mentais. A dialética é a compreensão da totalidade do real, incluindo, portanto, as operações do pensamento" (FERREIRA, 2006, p.69). A aplicação do conhecimento obtido nos estudos bibliográficos será empregada na análise do objeto em si e nos estudos de campo, podendo desencadear a comprovação ou não das hipóteses levantadas e também no relacionamento 
direto com os envolvidos no objeto de estudo, através de análise qualitativa e não quantitativa. Portanto, neste trabalho, far-se-á uso de entrevistas abertas.

“c) epistemologia: representa a teoria da ciência, ocupando-se do resultado cognoscitivo obtido, cristalizado em determinada ciência" (FERREIRA, 2006, p.69). A elaboração teórica dos conceitos poderá desencadear resultados que explicitarão se as manifestações das culturas populares subalternas podem ser possuidoras de especificidades avatárticas. Desta forma, a festa de Folia de Reis da região e da cidade de Ourinhos foi selecionada como objeto de pesquisa, por propiciar uma reflexão acerca das manifestações culturais pertencentes às culturas populares subalternas, nas suas relações com conteúdos de ordem ideológica, numa sociedade historicamente dada.

Ao longo do processo histórico de desenvolvimento do homem e de suas comunidades, as festas estiveram presentes como forma de marcar momentos iniciáticos da sua formação psíquica e social. As festas marcam a relação do homem com os ciclos da natureza, do tempo e das dinâmicas que cooperaram para perpetuar sua subsistência e sobrevivência, bem como com seus modos culturais. Também celebram sua relação com o incognoscível. Assim, as celebrações festivas sempre acompanharam a evolução da humanidade, recriando os marcos, históricos ou não, que compuseram seu desenvolvimento.

No Brasil, as atividades festivas também faziam parte das celebrações dos povos originários ${ }^{1}$ como agentes reguladores da dinâmica

\footnotetext{
${ }^{1}$ Neste trabalho os "índios" serão sempre identificados como povos originários, para evitar denominações carregadas de duplo sentido, bem como, denominações que solidificaram a vertente hegemônica da construção da história do país.
} 
social. Com a chegada do europeu e a transplantação das culturas da África, as festas ganharam amplitude; nelas foram agregados diferentes elementos simbólicos que conservaram a concepção e as formas ritualísticas de origem. A festa é sempre um acontecimento coletivo composto de um conjunto formal de procedimentos e atitudes que refletem as formas de pensar e agir de uma comunidade.

Deste modo, quando, no desenrolar da história brasileira, a coabitação no mesmo espaço forçou a convivência de diferentes culturas, as festas também incorporaram múltiplos elementos, fazendo surgir novos significados e simbolismos para atender às necessidades que se impunham no transcorrer de nossa formação cultural, mantendo, em suas ações ritualísticas, elementos originários de cada uma dessas culturas. Nesta perspectiva, transformam-se na síntese do sentimento de brasilidade, expresso na música, danças, dramatizações, nos sabores dos pratos servidos, nas vestimentas, adornos e na decoração dos espaços ocupados, assim como na síntese do sentimento de ações coletivas vinculadas à religiosidade, ao profano, ao civismo, ao lúdico e ao reflexivo. Em seus estudos, Ferreira tece considerações a esse respeito:
A festa reproduz simbolicamente a condição do caos mítico primordial, quando promove a anulação do presente. Assim, a festa é um simbólico retorno às origens - uma origem muitas vezes imaginária ou reinterpretada - necessário para garantir a integridade do indivíduo. (FERREIRA, 2005, p.75)

As festas se modificam dialeticamente dentro das necessidades e dinâmicas do momento histórico das comunidades, ocasionando uma configuração de semelhanças e diferenças marcantes. Na região estudada, como em todo o Brasil, as Folias de Reis mantêm em seu núcleo atitudes e elementos imutáveis - elementos avatárticos - que podem 
ser detectados em festas oriundas da Antiguidade, da Europa Medieval, de comemorações Africanas e dos Povos Originários.

Como dado constitutivo das primeiras indagações apresentadas, foram estudados concomitantemente os objetos estéticos produzidos para a realização e celebração das Festas de Reis e seus componentes iconográficos, bem como pinturas de artistas pertencentes às culturas populares que representaram e registraram as danças, instrumentos musicais, paisagens, espaços arquitetônicos, apropriações e delimitações espaciais, costumes e as organizações sociais das festas, que explicitam, ainda, valores estéticos, simbólicos e didascálicos, registrando as origens transregionais, pluriculturais e interculturais que distinguem a formação dos modos viventes das populações estudadas.

Portanto, sob a ótica do estudo da iconografia, é possível compreender que as representações imagéticas e os objetos produzidos para as festas cumprem dupla função: auxiliar no entendimento e perpetuação das práticas ritualísticas e simbólicas aglutinadoras dos grupos geradores das culturas populares subalternas e propiciar uma reflexão crítica sobre as inúmeras conceituações empregadas para compreender e classificar esse gênero de expressões artísticas brasileira.

Por isso, estudar as Festas de Reis como manifestações das culturas subalternas, promovidas por diferentes grupos, é uma forma de buscar informações nas próprias comunidades, da melhor maneira de entendê-las e de preservá-las, frente às constantes influências dos meios massivos de comunicação que podem provocar fortes rupturas nos seus modos de ser e existir. Essa dinâmica impõe a utilização de uma fundamentação teórica que 
contemple toda a riqueza e diversidade cultural encontradas nas festas e nas artes que se articulam com a estrutura psicossocial das populações estudadas. Nesta perspectiva, Ortiz considera que "a consciência popular opera por bricolagem, ao contrário da cultura burguesa, que é global e unitária" (ORTIZ,1985, p.45). Esta idéia de bricolagem orquestra a composição das bases culturais da brasilidade, que confere, por conseguinte, à riqueza e diversidade cultural encontradas nas festas e nas artes um outro status e tornam-se importantes veículos para explicar e fundamentar o conceito de cultura nacional não oriundo somente das culturas hegemônicas, como se convencionou apresentar ao longo da historiografia das culturas no país:

Os rituais e costumes do passado não são somente soluções úteis ou meras expressões conservadoras. Seu sentido vai mais longe e se mostra mais nítido quando se descobre neles formas de resistir aos efeitos deformadores da cultura dominante. Nestas manifestações, encontram-se soluções para 0 presente. Não se trata de conservadorismo, mas, em muitos casos, de preservação de uma base a partir da qual, resistir significa conservar a identidade, a dignidade e a solidariedade. (MAGUILES, 1991, p. 62).

Igualmente é preciso depreender esforços no sentido de registrar e ampliar a formação do conceito de brasilidade gerada nos núcleos subalternos de culturas. Os esforços alcançados pelo escritor Ariano Suassuna devem ser mencionados. Suas pesquisas congregam interesses vinculados às culturas do povo como forma de caracterizar e legitimar as artes do Nordeste e do país. Sua intenção é promover estudos, documentar e difundir essas manifestações, bem como utilizá-las como matriz geradora de uma arte erudita genuinamente brasileira.

Ao fundar o Movimento Armorial, projetou suas pesquisas para dentro do reduto das reflexões acadêmicas, normalmente reticentes quanto aos estudos das culturas populares subalternas: 
A Arte Armorial é aquela que tem como traço comum principal a ligação com o espírito mágico dos 'folhetos' do Romanceiro Popular do Nordeste (Literatura de Cordel), com a Música de viola, rebeca ou pífano que acompanha seus 'cantares', e com a Xilogravura que ilustra suas capas, assim com o espírito e a forma das Artes e espetáculos populares como esse mesmo Romanceiros relacionados. (SUASSUNA, 1974). ${ }^{2}$

O escritor defende sua crença nas manifestações populares como alicerce de uma arte erudita nascida do povo para ser usufruída por todos os participantes das comunidades nordestinas e do país. Seu trabalho manifesta a crença nas culturas populares como caminho para compreender as culturas latino-americanas, capazes de se afiançarem sem se submeter ao avanço descaracterizador das manifestações desencadeadas pela cultura de massa ou os efeitos da globalização, definidos por Suassuna como "novo colonialismo".

Desta forma, as Festas estudadas contemplam a originalidade cultural mencionada e impõem, por conseguinte, uma premente necessidade da utilização de uma fundamentação teórica que considere toda a riqueza produzida e encontrada nas festas registradas e de suas iconografias que se convertem em valiosas produções estético/simbólicas e artísticas.

Neste trabalho, a pesquisa de campo, tão necessária para subsidiar os estudos pretendidos, foi focada na região de Ourinhos/SP, devido às características peculiares de sua formação histórica e cultural. Foi realizado um levantamento histórico de sua formação para evidenciar as diferentes contribuições culturais que conferiram à região uma dinâmica de ocupação sócio-espacial muito peculiar, fazendo aflorar manifestações culturais significativas.

\footnotetext{
${ }^{2}$ Trecho do Manifesto Armorial, publicado em 1974, por Ariano Suassuna. Fundação Joaquim Nabuco. Disponível em : <www.fundaj.gov.br>. Acesso em 2 de Agosto de 2007.
} 
A cidade e região de Ourinhos apresentam-se como um rico objeto de estudo, pois nelas são encontradas características culturais oriundas dos múltiplos processos de ocupação do país e de elementos da atualidade como: a integração por rodovias e ferrovias (vista como veículo comunicacional que traz para a cidade a convivência com habitantes de diferentes regiões do país), a presença de um forte comércio, a implantação de indústrias, o trato com diferentes tecnologias de comunicação massiva que convivem, ainda, com práticas agrárias de pequenos produtores, assim como com a cultura do bóiafria proveniente da indústria canavieira.

Pelo que foi dito acima, estudar as culturas populares subalternas, promovidas pelos diferentes grupos da cidade e região, é uma forma de conhecer os mecanismos e os veículos comunicacionais que permitem a existência e adaptação de tradições que sustentam o mosaico cultural do país frente às influências dos meios de comunicação da contemporaneidade.

Pretende-se, também, apresentar informações de como se processam as formas de comunicação que permitem às comunidades formadoras das culturas subalternas da cidade de Ourinhos e região preservarem e vivenciarem suas festas. Em suas considerações, Ferreira (1995) aponta para a importância, bem como para a necessidade de estudar as manifestações culturais do povo e dar novo sentido à definição de cultura brasileira encontrada nos meios acadêmicos.

Tomando-se a cultura em seu sentido amplo, pode-se considerar que é no espaço cultural, na cotidianidade, portanto, que se dão as relações da classe subalterna com o mundo material e com as classes hegemônicas; as exposições dos valores modernizadores da cultura hegemônica; as manifestações das formas adaptativas, de resistência e de recriação do uso das mensagens que recebem, gerando formas peculiares de participar do mundo. Considerando ainda que o espaço da manifestação cultural é um espaço de 
manifestação de conflitos, entende-se que a cultura das classes subalternas só pode ser entendida a partir do processo ambíguo e conflitivo no qual ela está mergulhada na atualidade [...]

Nesse espaço conflitivo e adaptativo, a cultura subalterna refuncionaliza as mensagens recebidas, adaptando-as ao seu cotidiano. Daí resulta que as classes subalternas estruturam o seu mundo a partir de uma coexistência não harmoniosa, mas nem sempre conflitiva, com outras culturas e ideologias. Como resultado desse exercício de sobrevivência, a cultura das classes subalternas não é homogênea, pois nela convivem as influência das classes hegemônicas e dos valores civilizatórios ancestrais. (FERREIRA, 1995, p.25).

Portanto, para atender o proposto acima, neste trabalho foi necessário abordar separadamente seus elementos constitutivos. Assim, compreender a formação da região e da cidade de Ourinhos foi fator preponderante para prosseguir com as outras investigações e estudos; citando Boff (1997), "Para entender como alguém lê, e necessário saber como são seus olhos e qual é sua visão de mundo" e completa Hobsbawn (1984), "todas as sociedades [...] têm um passado, pois mesmo as colônias mais inovadoras são povoadas por pessoas oriundas de alguma sociedade que já conta com uma longa história". Esse é o perfil da maioria das cidades da região e de Ourinhos; mas, "ser membro de uma comunidade humana é situar-se em relação ao seu passado" Hobsbawn (1984). Deste modo, optou-se, no capítulo Uma História Feita de Outras Histórias, contar a história da região e da cidade de Ourinhos, para que o leitor pudesse compreender como é significativo encontrar nesta região um número tão expressivo de Festas de Reis, e também para que compreendesse por que essas festas são importantes objetos de estudos para se situar as festas tradicionais populares como elementos que perpetuam as tradições das culturas subalternas, independentemente das influências dos processos modernizadores.

No capítulo As Festas, aborda-se a importância das festas como representantes da cultura do povo e as implicações e desdobramentos 
do seu estudo. As festas são objetos de estudos pertinentes para se compreender o ethos cultural de uma nação ou região e também para compreender como incorporam os elementos fundantes da cultura brasileira. As Folias de Reis são apresentadas como constituintes das festas populares e fazem parte das manifestações culturais do país desde seus primórdios, estando presentes em praticamente todo o território brasileiro como festa característica das culturas populares subalternas.

O item quatro trata da Organização e Elementos das Folias de Reis e demonstra, de forma descritiva, os múltiplos elementos encontrados nas festas pesquisadas na região. Durante o trabalho de campo, a profusão de elementos constitutivos das Folias foi-se ampliando e percebeu-se que para compreender uma Folia de Reis é necessário compreender todas as implicações e tramas que nelas se desenrolam. Desta forma, o capítulo foi dividido em subitens para dar conta de toda essa complexidade e está assim constituído: Atribuições e Funções dos Participantes das Folias de Reis, no qual é descrita a função de seus principais componentes e como se interrelacionam; Elementos Iconográficos das Folias de Reis, em que se trata de sua importância para estruturar e manter os diferentes rituais que as compõem; sendo, portanto, necessário abordar, Os Diferentes Rituais da Folia de Reis para abarcar todas as relações que esses elementos desencadeiam.

Analisar esses elementos separadamente não caracteriza, neste trabalho, um estudo funcionalista, mas sim, que foi necessário entender todos esses elementos como estruturantes de um processo amplo e complexo de manifestação cultural que detém múltiplas formas de apresentação e constituição, convivendo num mesmo objeto de estudo. Necessário, portanto, 
para poder abarcar e compreender essa multiplicidade de elementos como um todo e em sua essência.

No capítulo Registro das Culturas Subalternas na Arte dos Artistas Populares, as artes visuais dos artistas populares são apresentadas como registros e fontes iconográficas das manifestações encontradas e gestadas nas comunidades estudadas. Explicitam ainda, valores estéticos, simbólicos e didascálicos, principalmente através das obras do acervo do Museu de Arte Primitiva de Assis “José Nazareno Mimessi”, fundado em 1982. Também foram analisados alguns registros do acervo do Centro de Documentação e Apoio à Pesquisa (CEDAP) da Universidade Estadual Paulista (Unesp) de Assis. Através desses documentos, foi possível dar voz aos artistas populares neste trabalho e, assim, os depoimentos selecionados foram apresentados de forma que não mutilassem a idéia de seus protagonistas; assim sendo, essas citações podem parecer longas para os padrões acadêmicos - convencionais - mas foram esses depoimentos que embasaram algumas das considerações quanto à arte e ao fazer dos artistas populares.

Portanto, as pinturas do Museu e os documentos do CEDAP adquirem a dimensão de objetos de estudos únicos e importantes para vislumbrar as particularidades artísticas; a linguagem visual pode ser convertida em sustentáculo do real, do imaginário e do espiritual. É no texto visual que se garimpam as imagens arquetípicas das comunidades e também das festas estudadas.

O último capítulo - O Avatar presente na Iconografia como Processo Comunicacional de Permanência da Folia de Reis - apresenta o 
conceito de Avatar. A palavra avatar é descrita em dicionários como tendo sua origem no sânscrito "Avatara" que significa descida, normalmente conotando uma das encarnações (religião) de Vishnu (Deus Hindu). Pode ser também uma manifestação corporal de um ser imortal, por vezes, até do Ser Supremo, além de significar transformação, transfiguração, metamorfose de uma entidade imaterial em entidade real que mantém a sua essência através dos tempos. Os elementos avatárticos estão presentes principalmente nas manifestações visuais das Folias. No capítulo, também foi explicitado como é possível reconhecer as múltiplas manifestações da cultura visual presentes nas festas estudadas, para fundamentar a importância das representações visuais na preservação e construção da identidade das festas das culturas subalternas. Portanto, das múltiplas manifestações culturais do Brasil, as festas são vistas neste trabalho como um fato social e comunicacional que revela as crenças e as tradições de uma comunidade. Nesse sentido, a festa transcende o fato em si, a realidade e a imaginação, e faz acontecer um evento coletivo que apresenta uma circulação de sentidos polivalentes. Em outras palavras, a vivência e a presença de diversos elementos que compõem os eventos festivos representam a configuração do material e do imaterial de um grupo social, ou seja, é um fato comunicacional por excelência. Configura-se como uma bricolagem de fatos que muitas vezes se perderam de sua origem, mas que continuam na memória coletiva e arquetípica de um grupo. A festa da cultura subalterna é um mosaico de diferentes manifestações esquecidas ou já recolhidas na memória longínqua que se apresenta com outras roupagens, "avatares". 
No entender deste trabalho, são essas manifestações, travestidas de elementos modernizadores, que dão sustentação e identidade cultural às diversas festas encontradas no país. Esse processo é também um processo de circularidade de bens culturais; não raro, manifestações das culturas hegemônicas penetram as culturas subalternas, assim como o inverso também acontece, desencadeando um processo de caráter comunicacional único.

Essa circularidade faz existir uma dinâmica de coexistência de diferentes culturas num mesmo espaço - esse é um fenômeno que caracteriza a contemporaneidade, a "Era das Culturas". (SANTAELLA, 2004).

Ainda, a Folia de Reis foi escolhida por ser a festa popular de maior relevância na região. As Folias de Reis nasceram como festas religiosas apartadas das manifestações oficiais da Igreja e, conseqüentemente, distanciadas das classes hegemônicas. Um "avatar" da cultura subalterna que pretende demonstrar que as festas são fatos mutantes e nelas as mudanças inquietantes da contemporaneidade também se fazem presentes.

O trabalho tem, também, a intenção de apontar para a ausência de estudos e debates sobre as culturas populares das classes subalternas, o que gera a exclusão das suas manifestações no dia-a-dia dos grupos urbanos e hegemônicos que negam sua existência, bem como apontar para a pouca divulgação, que as condena a ser vivenciadas somente nas próprias comunidades ${ }^{3}$. Existe um abismo no país entre a cultura letrada da

\footnotetext{
3 Em pesquisa realizada no Sistema Dédalus, da USP, no período de 10 anos (1998-2008) foram encontradas 135 teses que apresentavam assuntos sobre cultura popular, cultura subalterna e folclore brasileiro. Dentre essas, somente 14 apresentaram títulos rementendo ao estudo das festas e folguedos. $\mathrm{Na}$ biblioteca da ECA/USP, no mesmo período, a pesquisa resultou em 11 títulos, sendo 9 sobre festas e folguedos.
} 
academia e as culturas do povo. Esse abismo cria uma persistência nas formas de pensar a cultura, perpetuando uma dicotomia e um antagonismo. 


\section{UMA HISTÓRIA FEITA DE OUTRAS HISTÓRIAS}

\subsection{A Boca do Sertão}

Todo ser humano tem consciência do passado (definido imediatamente anterior aos eventos registrados na memória de um indivíduo) em virtude de viver com pessoas mais velhas.

Provavelmente todas as sociedades que interessam ao historiador têm um passado, pois mesmo as colônias mais inovadoras são povoadas por pessoas oriundas de alguma sociedade que já conta com uma longa história.

Ser membro de uma comunidade humana é situar-se em relação ao seu passado (ou da comunidade), ainda que apenas para rejeitá-la.

O passado é, portanto, uma dimensão permanente da consciência humana, um componente inevitável das instituições, valores e outros padrões da sociedade humana. O problema para os historiadores é analisar a natureza desse "sentido do passado" na sociedade e localizar suas mudanças e transformações.

Eric Hobsbawn (1984)

A região e a cidade de Ourinhos podem ser percebidas como um mosaico de culturas e de tradições, em decorrência do histórico de sua formação. Esse histórico conduz para a idéia de que essas comunidades se estruturam como uma colcha de retalhos ou uma história feita de outras histórias. Cada retalho possui características próprias, mas juntos formam um todo coeso. A imagem da formação da cultura brasileira e da região como uma colcha de retalhos é muito pertinente quando se pensa no resultado obtido após a confecção de uma peça com retalhos: eles não se superpõem e também não se misturam, eles se completam lado a lado, buscando um diálogo com o próximo sem perder seu colorido, sua particularidade. Nas colchas de retalhos das casas de avós e mães é possível reconhecer o tecido do vestido da tia tal, da camisa da primeira comunhão de outro, da cortina da sala, do 
vestido da formatura, tecidos caros e importados com tecidos de toalha de mesa e de "chita". No entender desta pesquisa, o viver, o cotidiano, o desenrolar da história foi sendo costurado com a herança cultural de cada indivíduo, grupo, país e dos acontecimentos mundiais que deslocaram reverberações para a região e para a cidade.

A imagem da colcha de retalhos para vislumbrar a formação da cultura brasileira não é exclusiva deste trabalho. No documentário "O povo brasileiro", feito pela fundação Darci Ribeiro, ela, a colcha de retalhos, está presente no cenário em que foram gravados os depoimentos e considerações teóricas de diferentes estudiosos de nossa formação cultural, está lá como "pano de fundo".

Portanto, explicitar a origem do povoamento de Ourinhos e região como uma colcha de retalhos é valorizar as "pequenas histórias", é valorizar o cotidiano, o viver, as ações dos anônimos, ou seja, é valorizar as contribuições das culturas subalternas como atores dos fatos que quase nunca são contemplados nos discursos acadêmicos e hegemônicos.

Dentre as contribuições teóricas elaboradas para se compreender a grande colcha de retalhos que é a cultura brasileira e a da região, merece destaque a de Vanucchi, que em seu livro Cultura Brasileira: $O$ que é, como se faz, divide a cultura do país em duas possíveis linhas de compreensão: "a cultura universal de que o Brasil participa do seu jeito" e "a cultura específica criada pelo povo brasileiro". Assim, o autor procurou evidenciar, por meio de pesquisas bibliográficas, principalmente de livros escritos por pesquisadores e estudiosos residentes na região - muitos escritos tendo como referências os relatos de seus antepassados - e dos depoimentos 
colhidos em entrevistas, as características da formação histórica da cultura regional fundamentada no cotidiano das comunidades, assim como, os modos de viver que foram elaborados pelo povo. Nesta perspectiva Vanucchi explicita:

\begin{abstract}
A cultura não existe em seres humanos genéricos, em situações abstratas, mas em homens e mulheres concretos, pertencentes a este ou àquele povo, a esta ou àquela classe, em determinado território, num regime político $\mathrm{A}$ ou $\mathrm{B}$, dentro desta ou daquela realidade econômica.

Somente se poderá conceituar cultura como auto-realização da pessoa humana no seu mundo, numa interação dialética entre os dois, sempre em dimensão social. Algo que não se cristaliza apenas no plano do conhecimento teórico, mas também no da sensibilidade, da ação e da comunicação. (VANUCCHI, 2002, p. 21).
\end{abstract}

No século XVI, na região Sudeste, onde se localizava a Vila de Piratininga, atual cidade de São Paulo, fundada por jesuítas, teve início, a partir dessa localidade, a abertura dos núcleos de colonização do interior do país e, principalmente, do Estado de São Paulo, período conhecido como "bandeiras". Estas expedições adentravam os sertões em busca de riquezas e caça aos povos originários para escravizá-los; por volta de 1690, as bandeiras encontraram ouro na região hoje conhecida como Minas Gerais. O marco geográfico que indicava a região com os veios do ouro passou a ser denominado de "Pedra de Itacolomi" ou "Dedo de Deus", próximo à atual Ouro Preto. Este achado desencadeou uma corrida do ouro para a região; muitos vieram de São Paulo, Bahia e de Portugal. As "Minas Gerais foram, pois, uma verdadeira 'ilha de riqueza' em meio à floresta interior do Brasil”. (RAMOS, 1969, p.129). A descoberta de metal precioso mudou radicalmente o fluxo de colonização da colônia, estabelecida desde seu início do litoral para o interior; "os livros de navegação, daqueles tempos, registraram todos os anos a saída de mais de 20.000 pessoas que se dirigiam de Portugal para o Brasil e isso no 
período de 1705 a 1750". (RAMOS, 1969, p.131). E as Minas Gerais passam a abrigar os primeiros grandes núcleos urbanos do interior do país.

A extração do ouro foi abundante e vertiginosa, assim como seu esgotamento; a exaustão dos veios de ouro de Minas Gerais provoca uma nova etapa da colonização do país e uma onda de migração desloca desbravadores para o Oeste do Estado de São Paulo onde se localiza o médio Paranapanema, em terras até então não desbravadas, conhecidas como: "Boca do Sertão", "Terra de Ninguém", "Inferno Verde" ou "Nova Boca dos Sertões". O mapa 2.1, mapeado por Penço (1980), em sua Tese de Doutorado, situa o que era conhecido como o Sertão.

Mapa $2.1^{4}$

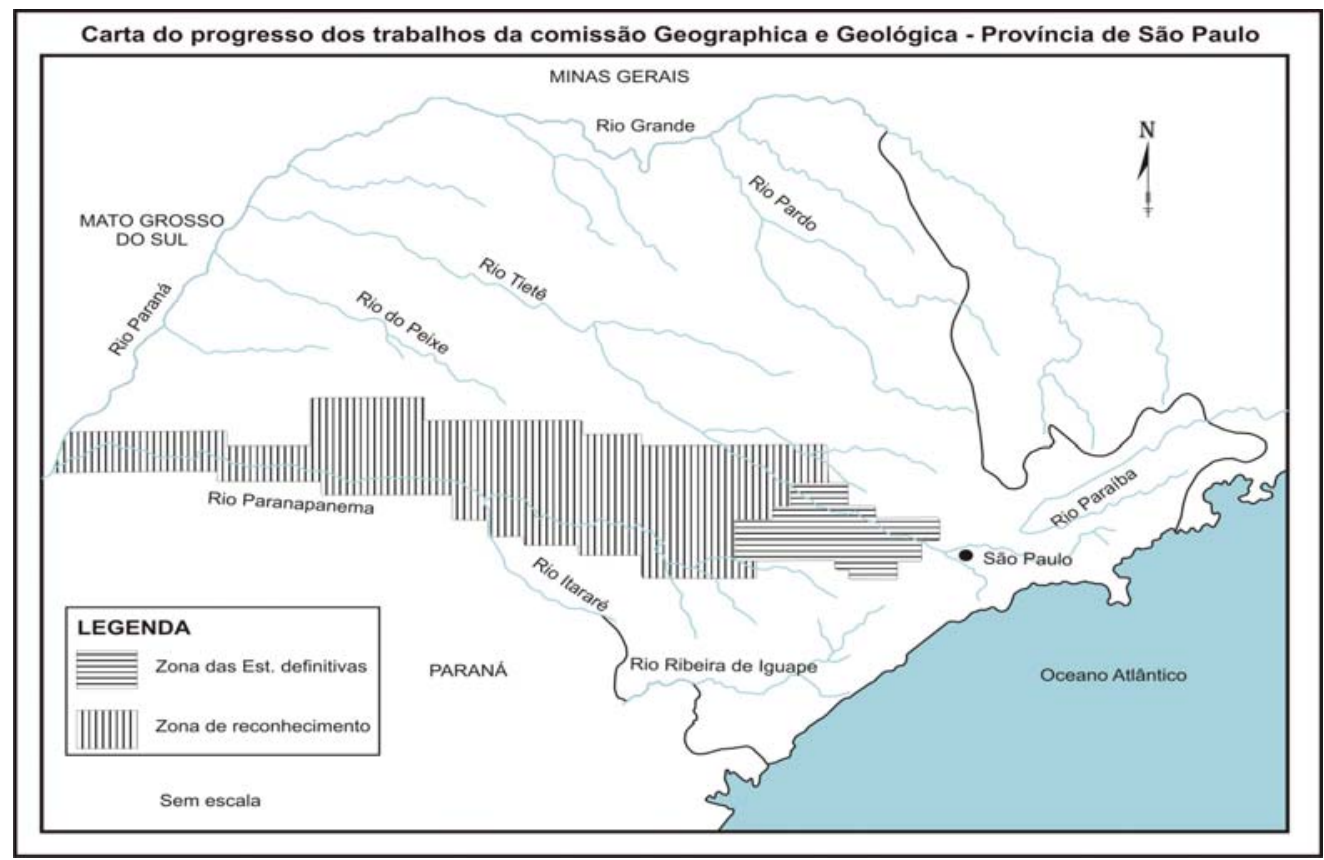

As primeiras povoações limites do Oeste Paulista que serviam de adentramento para a "Boca do Sertão" eram: Botucatu, fundada em 1843,

\footnotetext{
${ }^{4}$ Mapa refeito pelo geógrafo Weslei Reghini (UNESP, Ourinhos), a partir do original da tese de doutorado de PENÇO, D. C. F. Célia. A evaporização das terras devolutas no Vale do Paranapanema. Instituto de Geografia Humana, Universidade de São Paulo, São Paulo, 1981.
} 
conhecida como a capital do oeste até meados do século $X X$, e Lençóis Paulistas que foi elevada à freguesia em 1858 e dividia com Botucatu a centralização do comércio e a administração política e religiosa da região. Os mapas 2.2 e 2.3, também mapeados por Penço (1980) demonstram o percurso feito pelos primeiros desbravadores que adentraram a região desconhecida.

Mapa 2.2 A Penetração e a Posse dos Mineiros no vale do Paranapanema em Meados do séc. XIX ${ }^{5}$

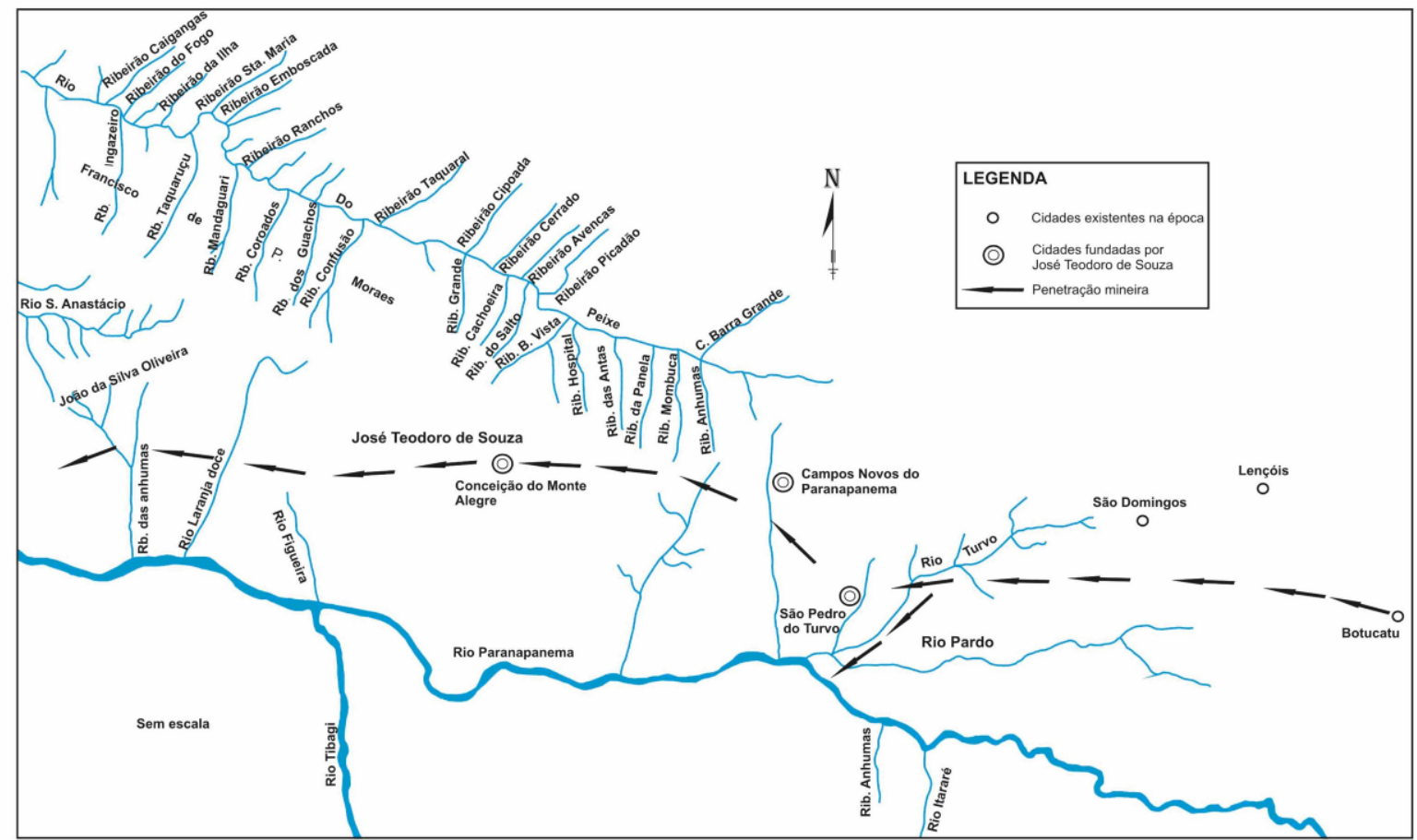

\footnotetext{
${ }^{5}$ Mapa refeito pelo geógrafo Weslei Reghini (UNESP, Ourinhos), a partir do original da tese de doutorado de PENÇO, D. C. F. Célia. A evaporização das terras devolutas no Vale do Paranapanema. Instituto de Geografia Humana, Universidade de São Paulo, São Paulo, 1981.
} 
Mapa $2.3^{6}$

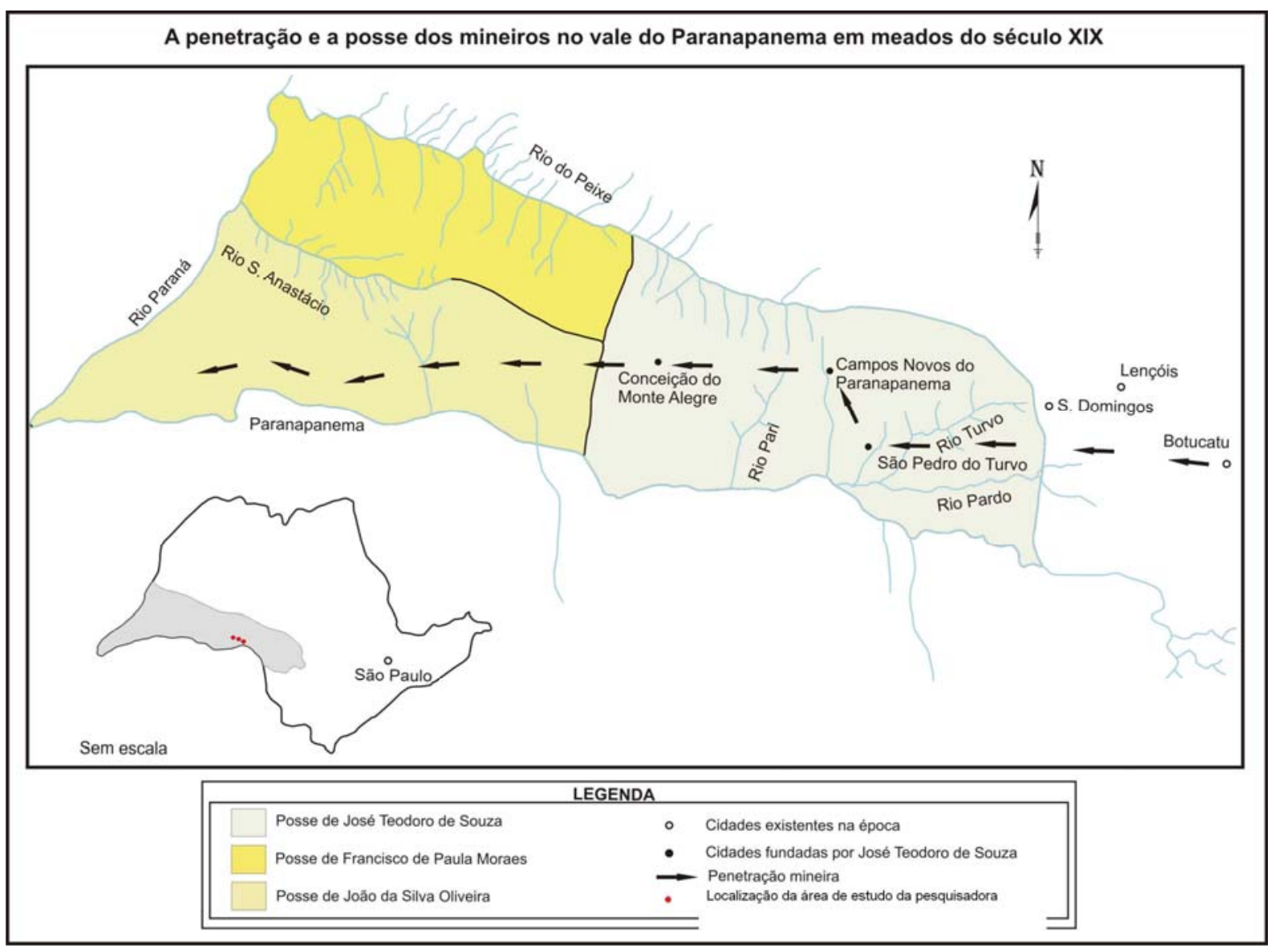

Nesta mesma época, Tito Correia de Melo, homem de prestígio e poder em Botucatu, articula a vinda de novos desbravadores, providenciando a posse das terras. Esse morador, influente nas cidades limites da chamada "Boca do Sertão", articulou a vinda de mineiros que deram início à apropriação e posse das terras da região. Outro fator que estimulou esse deslocamento foi a proximidade da vigência da Lei Imperial $\mathrm{n}^{\circ}$. 601 de 18 de setembro de 1850, que, no $\S 1^{\circ}$, proibia a ocupação de terras devolutas por outro título que não fosse por compra. Essas conjunturas configuraram o quadro que provocou um deslocamento sucessivo de famílias oriundas de cidades como: Pouso Alegre,

\footnotetext{
${ }^{6}$ Mapa refeito pelo geógrafo Weslei Reghini (UNESP, Ourinhos), a partir do original da tese de doutorado de PENÇO, D. C. F. Célia. A evaporização das terras devolutas no Vale do Paranapanema. Instituto de Geografia Humana, Universidade de São Paulo, São Paulo, 1981. A indicação da área de estudo foi acrescentada a pedido da pesquisadora para destacar a região estudada.
} 
Machado, São João Del Rey, Alfenas, Ouro Fino, Congonhal, que se reuniram, provavelmente, com seus parentes, agregados e escravos para desbravar a região e garantir posse de novas terras, fazendo uso, preferencialmente, dos caminhos demarcados pelos rios.

Viam, no acúmulo de terras, a forma de se estabelecerem, forçando a expulsão ou o extermínio dos povos originários e mantendo uma produtividade suficiente para o seu sustento. Esse processo se mantém entre as décadas de 1850 e 1870. O apossamento das terras é a origem da colonização da "Boca do Sertão".

Por volta de 1851, o mineiro José Teodoro de Souza parte de Pouso Alegre, a convite de Tito Correa de Mello, junto com outros desbravadores. Sua comitiva passa por Mogi Mirim e chega a Botucatu. Nesta marcha para o coração do sertão, colaborou com a abertura de Avaré e também com a fundação da cidade de Santa Bárbara do Rio Pardo; nesse processo participa do extermínio de muitos Caiuás. Continua a caminhada para o Oeste, conquistando um dos maiores latifúndios que se conhece na história judiciária do Estado de São Paulo. Tem como demarcador geográfico a Bacia do Rio Pardo, cruza o Rio Turvo, chega ao Ribeirão do São João e na confluência desses rios funda a Vila de São Pedro do Turvo. Católico, ergueu uma capela na confluência dos Ribeirões São João e São Pedro. Assenta sua família e de outros companheiros de viagem, como, João da Silva Oliveira, Antonio da Silva Oliveira, Bernardino da Silva Oliveira e Antonio de Paula Rodrigues, às margens desses rios e estabelece uma pequena lavoura. Nos livros que relatam a formação dessas cidades, encontramos comprovação das práticas usadas por José Teodoro para consolidar seu latifúndio: 
[...] vão deixando nas melhores regiões de cultura pessoas de sua confiança, que garantiam a posse com a construção de ranchos, com culturas diversas e especialmente plantando laranjeiras para o efeito do competente registro paroquial como determinava a legislação do império. (RIOS, 2004, p.13).

Esse adentramento não foi feito pacificamente; os povos originários foram forçados cada vez mais a se embrenharem no sertão ou exterminados, provocando uma relação de conflitos, pois

a região era também habitada por índios, que freqüentemente entravam em conflito com os colonizadores, tanto que, no período inicial, entre 1855 e 1860, quando os povoadores partiam para o trabalho nas roças, levavam a mulher, os filhos, os animais domésticos e objetos de uso, pois podiam ser massacrados ou destruídos e roubados pelos índios. Dos animais, odiavam os índios, especialmente os cães cujo os faros lhes denunciavam a aproximação. (DANTAS, 1980, p.32 e 33).

$\mathrm{Na}$ investida para a conquista de seu latifúndio, há relatos de

encontros de José Teodoro com os Coroados. Fontes o descrevem como sendo benevolente para com os povos originários:

era analfabeto; e se tem como homem generoso, bom e caridoso, protetor de toda a gente. Inclusive, não quis seviciar os índios, mas atraí-los com amor à Civilização, - o que não concorda com sua atuação anterior, no Abaré-i ${ }^{7}$, segundo Hernâni Donato, tanto que os índios o tratavam de 'Pai'. (DANTAS, 1980, p.33).

Nos escritos e relatos da época, normalmente, os povos originários são denominados pejorativamente de bugres. Os povos originários da região são descritos como procedentes de três nações: "Os Coroados na vertente do Rio do Peixe, os Cayuas Guaranis no Rio Paranapanema e os Xavantes na parte central." (CUNHA, 1996, p.27).

José Teodoro é tido como o fundador de São Pedro do Turvo, Campos Novos e Conceição do Monte Alegre, hoje distrito de Paraguaçu Paulista, entre outros. Após estabelecer as primeiras povoações, desce em

\footnotetext{
${ }^{7}$ Abaré-i é considerado nos dias atuais o município de Avaré/SP.
} 
direção ao Vale do Paranapanema e usa esse rio como guia e via para chegar até o Rio Tibagi, no atual estado do Paraná, demarcando parte de seu latifúndio.

Logo após registrar e legalizar a posse de suas terras, retorna a Minas Gerais e divulga suas conquistas trazendo, assim, novos colonizadores para a região. Nesse processo, os novos colonos utilizam as trilhas já demarcadas pelos povos originários, os caminhos dos tropeiros, os caminhos navegáveis e os demarcados por José Teodoro. Chegam outros pioneiros, entre eles, Joaquim Manuel de Andrade que fundou a cidade de Santa Cruz do Rio Pardo; e na cidade de Avaré, chegam João Antonio Justino (João dos Santos) e João Corrêa de Miranda. Esses vieram também com famílias e alguns escravos, estabeleceram-se à margem do ribeirão conhecido como Coqueiral, dando início ao município de Ipaussu.

A chegada desses pioneiros desencadeia a colonização da "Boca do Sertão" e outros aventureiros migram e se fixam na região, para a lida com a terra, a abertura de comércios e 0 trato com as atividades administrativas dos povoados, contribuindo para que as vilas fundadas se solidificassem e se estruturassem como cidades: "construíram igrejas, posto policial, abriram escolas, ampliaram o comércio, e elevaram-se da condição de freguesias e vilas para cidades, demarcando o que se denominou de 'Oeste Novo Paulista'." (ARGOLLO, 2004, p.166).

Nos processos de fundação das cidades, desde o início da colonização, três elementos aparecem como fatores importantes para o desenvolvimento; "como se vê, logo desde o começo existiram os elementos 
essenciais para o progresso que são: a religião, a autoridade e a justiça" (LEITE, 1936, p.30). E, na região, essa tríade não foi alterada.

A notícia dos feitos desses pioneiros desencadeou uma segunda corrida do ouro, mas, desta vez, o ouro estava plantado nas terras roxas e garimpado na colheita dos infindáveis pés de cafés. Muda-se a paisagem da região, extinguem-se as matas e brota o café. Entre 1880 e 1900, outros migrantes e imigrantes adquirem as terras já desbravadas e desenvolvem uma agricultura cafeeira moderna. Estes cafeicultores haviam aprendido com os erros de seus antecessores do Vale do Paraíba e das fazendas oriundas da região de Campinas - criam uma produção altamente lucrativa vinculada à sociedade capitalista que emergia. Surge o agronegócio do café. Desta forma, a colonização da região compreende dois momentos distintos, segundo Souza Martins (1978, apud PENÇO, 1980): o primeiro, com o desbravamento do sertão e o segundo, na transformação do sertão em uma das principais regiões produtoras de café no fim do século XIX e nas primeiras décadas do século $X X$.

Com o desenvolvimento dos municípios, instala-se também uma agricultura familiar diversificada, de pequenos produtores, plantando arroz, milho, algodão, amendoim, mandioca, abastecendo as grandes lavouras de café e as novas cidades. No surgimento dos municípios e fazendas cafeeiras da região, pouco se usou de mão-de-obra escrava, em decorrência das pressões pela abolição e pela utilização dos negros na guerra do Paraguai; houve predomínio de colonos que migraram de outras regiões, principalmente de Minas, das grandes fazendas cafeeiras do norte e leste do estado e das 
levas imigratórias da Europa e Ásia que trabalharam na construção das Estradas de Ferro, bem como nas lavouras que se estabeleciam.

\subsection{As Linhas da Estrada de Ferro como Veículos de Comunicação}

As ferrovias significaram na Europa o coroamento de uma nova ordem que surgia, a Era da Indústria, com o triunfo das máquinas a vapor, símbolo do desenvolvimento, da integração e do avanço tecnológico. No Brasil, chegaram logo após sua expansão européia e foram vistas como possibilidade de rompimento com as atividades arcaicas, como o tropeirismo lento, e com um Brasil agrário pouco rentável em decorrência do ciclo do ouro, também, recém saído da condição de colônia para um país independente e, portanto, frágil em suas estruturas; o que dificultava sua expansão. Neste contexto, surge a estrada de ferro e o país apropria-se do moderno e de um novo veículo comunicacional, bem como de um novo veículo de transmissão e integração das manifestações culturais do país. A Estrada de Ferro Sorocabana tem sua origem neste momento.

A Sorocabana foi fundada no início da década 1870, por Luís Matheus Maylasky que a comandou até 1882, passando em seguida a ser dirigida pelo banqueiro Francisco de Paula Mayrink. Sua fundação está ligada ao inconformismo de um influente grupo de fazendeiros sorocabanos que não aceitaram que a estrada de Ferro Ituana, que ligava Jundiaí a Itu, fundada no mesmo ano, não contemplasse a cidade de Sorocaba. 
As obras foram iniciadas em Ipanema, atual Varnhagem, em 1872, mais especificamente na Real Fábrica de Ferro de Ipanema, próximo a Sorocaba. O trecho entre Ipanema e São Paulo foi inaugurado em 1875. A Estrada de Ferro Ituana foi uma grande concorrente da Sorocabana, provocando disputas que acabaram em 1892 devido à junção das duas ferrovias. Tornou-se a Companhia União Sorocabana e Ituana. Posteriormente, com a crise econômica, o Governo Federal encampou a ferrovia em 1904; no ano seguinte, passou o comando para o Governo Estadual. Porém, dois anos depois, o senhor Percival Farquhar da Brazil Railway arrendou a Sorocabana, e várias outras ferrovias do país, renomeando-a de Sorocabana Railway Company. Em 1919, foram realizados muitos investimentos e importações na compra de locomotivas e a linha tronco alcançou as margens do rio Paraná, em Presidente Epitácio. Acabado o arrendamento, o Estado de São Paulo voltou a comandar a ferrovia, denominando-a Estrada de Ferro Sorocabana ${ }^{8}$.

A instalação desse novo meio de transporte proporcionou benefícios para os produtores agrícolas do país que buscavam um meio mais eficiente e mais rápido para a exportação de seus produtos. As Ferrovias do Estado de São Paulo foram responsáveis pelo crescimento percentual de linhas férreas no país e transportaram, principalmente, produtos agrícolas para o porto de Santos, para serem exportados. No Estado de São Paulo, o transporte de cargas centralizou-se no café; foi essa cultura o motivo de sua expansão e decadência. Canabrava (apud SAES, 1981, p. 40-41) justapõe a ligação estreita entre a construção de ferrovias com a produção de café. Esse processo também está vinculado à expansão do Oeste Paulista. No Estado de

\footnotetext{
${ }^{8}$ As estradas de Ferro do Estado de São Paulo. Disponível em: <www.estacoesferroviarias.com.br>. Acesso em 2 de Agosto de 2007.
} 
São Paulo, em grande parte, a construção de ferrovias foi um investimento dos próprios fazendeiros do café. Monbeig (apud SAES, 1981, p. 33) afirma que "o desenvolvimento das vias férreas não obedeceu, pois, a um plano sistemático: ele foi comandado pelos interesses de administradores, produtores e comerciantes de café". Reforça que as novas vias férreas eram obrigadas a mudar seu traçado, devido à localização das grandes fazendas e das cidades produtoras de café, tornando-se conhecidas como as vias férreas do café.

Saes (1981) destaca que para haver estrada de ferro, foi necessária a presença de população e produção. Portando, se fez indispensável farta mão-de-obra em várias localidades. Por isso, os cafeicultores propuseram que, para haver trabalhadores suficientes, seria imprescindível a imigração:

No Oeste Paulista, a proporção de escravos para trabalhadores livres diminuiu significativamente. A maior parte das fazendas instaladas na região após 1880 passou a contar com trabalhadores livres em grande número e o reflexo imediato sobre seu ambiente construído foi a intensificação das construções destinadas à produção agrícola e à moradia: saem de cena as senzalas e surgem as colônias. (ARGOLLO, 2004, p.36).

Assim, as companhias ferroviárias ofereciam passagens gratuitas aos imigrantes e os conduzia até os locais que necessitavam de trabalhadores qualificados em suas construções e também nas lavouras de café.

Essa dinâmica desencadeia a relação estreita entre o desenvolvimento das ferrovias, a produção de café e a propagação da população no Estado de São Paulo, ocorrendo, desta forma, o desenvolvimento das cidades que foram criadas entre meados e fins do século XIX. 
Saes (1981, p.53) ainda ressalta que "o período de 1900 a 1920 marca o estabelecimento do que praticamente constitui a rede ferroviária definitiva de São Paulo". Neste período, consolida-se a instalação de um tronco ferroviário básico e ramais de importância secundária são construídos, como o que ligava Bernardino de Campos a Santa Cruz do Rio Pardo. Esta evolução pode ser percebida no mapa 2.4 , que representa o traçado das linhas Ferroviárias no ano de 1987 no Estado de São Paulo.

Mapa 2.4: Linhas Ferroviárias de SP, em $1987^{9}$

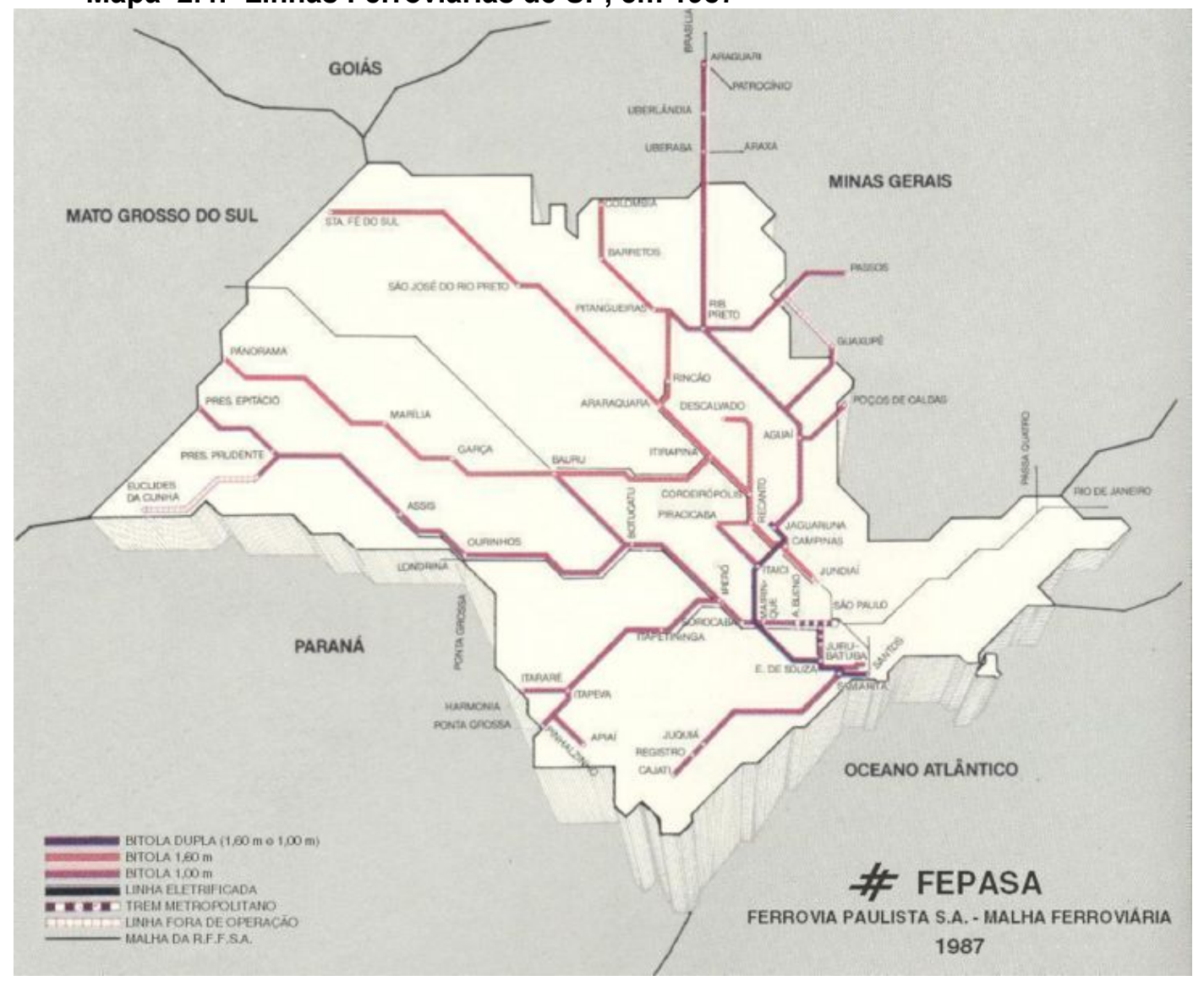

9 Mapa das estradas de ferro do Estado de São Paulo em 1978. Disponível em: <http://www.qsl.net/pu2tjq/trembauru/fepasa1987gd.jpg>. Acesso em: 17 de agosto de 2007. 


\subsection{No Fim da Linha, a Cidade de Ourinhos}

A cidade de Ourinhos tem sua origem num acampamento construído em 1905 para abrigar trabalhadores e materiais necessários para a expansão da Estrada de Ferro Sorocabana no trecho entre Ipaussu e Salto Grande. A ferrovia findava em Cerqueira César; "consta que nessa época existiam 231 edificações, na maioria habitadas por trabalhadores que desmatavam as áreas destinadas ao assentamento de trilhos" (D’ AMBRÓSIO, 2004, p.12).

Com a chegada dos trilhos em Salto Grande, o acampamento tornou-se posto da Estrada de Ferro - estação - inaugurado em 31 de dezembro de 1908. No espaço de dois anos, surge a pequena vila de Ourinhos, com posto policial e escola pública; uma característica da vila eram as pensões procuradas por funcionários da estrada de ferro, caixeiros-viajantes e trabalhadores em trânsito para as grandes lavouras de café que se abriam neste período no Paraná e as já existentes nas consolidadas fazendas paranaenses de Jacarezinho e Ribeirão Claro.

As terras que circundavam a vila, pela boa qualidade e produtividade, ganharam fama e muitos fazendeiros que moravam na capital e em outras cidades de regiões desenvolvidas e com sólidos empreendimentos direcionaram seus investimentos para a pequena Ourinhos. Desta forma, atrelam-se a sua história nomes e personalidades como: Dona Escolástica Melchert da Fonseca, figura emblemática da expansão da cidade de São Paulo, em cujas terras, à margem direita do Rio Tietê, originou-se o bairro da 
Vila Matilde; João Baptista de Mello Peixoto, jurista e político influente; Ataliba Leonel, deputado atuante de Piraju, "dividia o poder no estado com Washington Luís e Julio Prestes" (D’ AMBRÓSIO, 2004, p.21); José Carlos de Macedo Soares, esposo de Matilde, filha de Dona Escolástica, proprietários da Fazenda das Furnas, bem como Antonio de Almeida Leite, vindo de São Carlos do Pinhal em 1915, proprietário de 600 alqueires de terra próximos ao córrego do Lageadinho, que demarcou parte do município. Destaca-se, também, Antonio José da Costa Junior, proprietário de terras onde hoje é o bairro da Água Branca na capital. Uma de suas filhas casa-se com Carlos de Abreu Sodré, médico que clinicou na cidade e foi proprietário da "Fazenda Ourinhos". Esta fazenda era da Companhia Agrícola Costa Junior, "única no estado de São Paulo que exportava café diretamente para a Europa. Produzia ainda milho, arroz e criava gado holandês" (D’ AMBRÓSIO, 2004, p.17); seu filho, Roberto Costa de Abreu Sodré, foi governador do Estado.

A fazenda Santa Maria, segundo D’Ambrósio (2004), foi de Fernando Pacheco e Chaves, filho de Elias Chaves, que construiu em São Paulo o Palácio dos Campos Elíseos, antiga sede de governo. Foram proprietários da Sociedade Prado Chaves \& Cia., depois Cia. Prado Chaves Exportadora, donos de grandes armazéns no município; estes e outros depósitos caracterizaram o comércio atacadista da cidade no seu início e nas décadas seguintes. O filho do grande médico Emílio Ribas, Paulo Balcão Ribas, também médico, foi pioneiro; clinicava na cidade e era proprietário da fazenda Múrcia. Esses nomes estão relacionados ao de Jacinto Ferreira de Sá, figura central da história e desenvolvimento da cidade. Mineiro, filho de Manuel Ferreira de Aguiar de Sá, que migrou da região de Diamantina nos meados do 
século XIX com esposa e os oito filhos, acreditava que o futuro estava nas novas regiões do Oeste do Estado de São Paulo, fixando-se, pois, em São Simão.

Jacinto e dois irmãos, posteriormente, vieram para Santa Cruz do Rio Pardo, comercializaram "secos \& molhados" em um estabelecimento que prosperou, levando o nome de Três Irmãos. Também se dedicou a transportar cargas que abasteciam seu estabelecimento e de outros comerciantes. Este empreendimento Ihe abriu a possibilidade de contato com importantes personalidades da época.

Jacinto Ferreira de Sá, num curto espaço de tempo, torna-se próspero fazendeiro em Santa Cruz do Rio Pardo, expande suas terras para Ourinhos. Possuía 1.065 alqueires em suas proximidades antes de sua transação com a fazenda das Furnas, o que totalizou 2.295 alqueires. Estas terras o transformam em figura central no desenvolvimento da cidade. $O$ interesse dos proprietários nas ótimas terras do município e a influência de Jacinto foram decisivos para articular e traçar a rota da estrada de ferro. Chegou a solicitar para a Companhia que a estrada passasse em suas terras na fazenda das Furnas, mas as condições do terreno obrigaram a mudança do traçado e a estrada passou em sua outra propriedade, no limite com a fazenda Santa Maria de Fernando Pacheco Chaves. Estes fatos corroboram o argumento de Monbeig (apud SAES,1981, p.42):

Até a última década, os grandes fazendeiros foram de algum modo os dirigentes de São Paulo, o interesse coletivo era confundido com o seu interesse de classe. Este fato sociológico se liga à geografia do movimento pioneiro. Os problemas de mão-de-obra e conseqüentemente o povoamento, o das vias de comunicação, o dos preços foram considerados e tratados antes de tudo em função dos interesses de fazendeiros; a marcha pioneira foi antes de mais nada o seu negócio. 
O interesse de Jacinto e dos outros proprietários de terras que visavam à expansão e melhoria de seus empreendimentos promoveu o desenvolvimento da cidade; esses fatos foram decisivos para sua consolidação como centralizadora do comércio na região. Outro fator apontado como importante foram suas características geoespaciais que contribuíram, desde sua formação até o presente, para convergir interesses e investimentos; importantes cursos de água cortam o município: o rio Paranapanema, o rio Turvo e o rio Pardo. Hoje, também, sabe-se estar a região sobre o aqüífero Guarani. Essas configurações tornam suas terras atraentes para o plantio, assim como a abundância de água atraiu a instalação de hidroelétricas e possibilitou o desenvolvimento agroindustrial.

As ferrovias transformaram também a cidade em marco de integração com diferentes regiões do país, em decorrência de ser um entroncamento. Suas linhas vão para o Norte Novo do Paraná até Cianorte; para o Sul até o litoral, no porto de Paranaguá e Santa Catarina; para Presidente Epitácio; para a capital paulista e o porto de Santos. Posteriormente ao apogeu das estradas de ferro, importantes rodovias, como a Transbrasiliana, Raposo Tavares e Castelo Branco, que fazem o trânsito entre as regiões Sul, Sudeste, Noroeste e Centro-Oeste do país, passam pelo seu perímetro, totalizando duas federais e quatro estaduais. O mapa 2.5 , segundo D’Ambrósio (2004), representa a espacialidade das ferrovias e rodovias que cortam a cidade. 
Mapa 2.5: Espacialidade de Ferrovias e Rodovias que cortam Ourinhos/SP

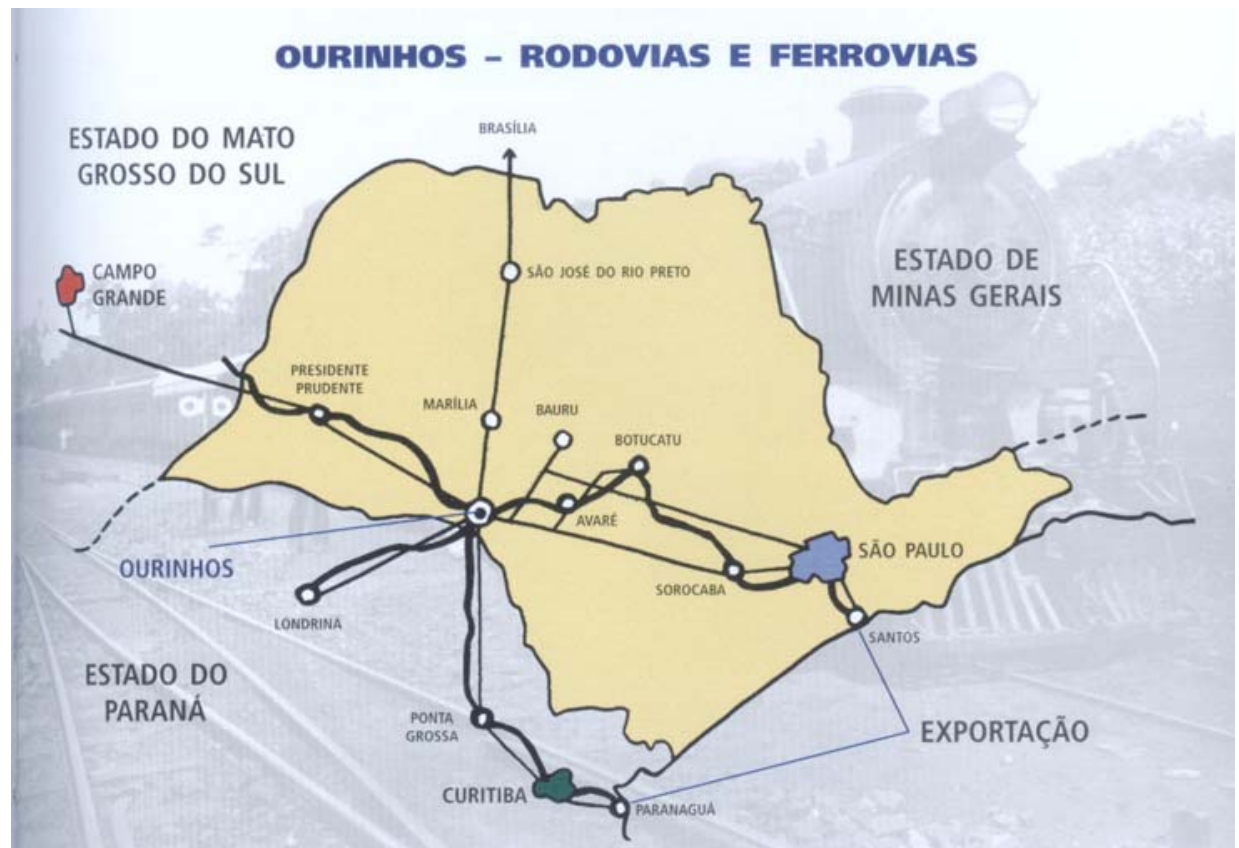

Fonte: Ourinhos: um século de história, organizado por Oscar D’Ambrósio.

Ed. Noovha América, 2004. p. 25

Essa espacialidade serve também como canal mediador de um processo comunicacional, criando uma configuração de convivência que desencadeia trocas e adaptações culturais; sua localização de fronteira com o Paraná ainda Ihe confere a possibilidade de articular uma frutífera interação sócio-econômico-cultural.

Segundo Boscariol (2006), o município de Ourinhos foi oficialmente criado em 13 de dezembro de 1918 e, nos anos seguintes, seu crescimento foi notável. Jacinto Ferreira de Sá manteve-se sempre empenhado nesse desenvolvimento e, quando foi prefeito da cidade, nos anos de 1923 a 1925, loteou terras e planejou sua configuração urbanística com traçados de ruas largas em linhas retas, características urbanas que se opuseram ao núcleo urbano desordenado de seu início.

Essa característica de urbanização foi influenciada pelos empreendimentos desencadeados pela Companhia de Terras Norte do Paraná 
e também pelas vilas construídas na cidade para abrigar os dirigentes ingleses da ferrovia e os próprios trabalhadores. Hoje, a cidade convive com estas influências urbanas que a aproximam das configurações urbanísticas das suas contemporâneas paranaenses e não com as cidades vizinhas, marcadamente influenciadas pelas construções e urbanização trazidas pelos seus primeiros pioneiros do sul de Minas.

Em 1922, a partir da estação de Ourinhos, a ferrovia adentra o estado do Paraná. Este avanço teve como conseqüência o crescimento e a abertura de inúmeras cidades como: Londrina, fundada em 1934, e Maringá, em 1948, que configuram o chamado Norte Novo do Paraná. O pequeno vilarejo de Ourinhos conheceu, também, em decorrência desta expansão, um forte desenvolvimento.

A construção da ferrovia para o Paraná deve-se a Antônio Barbosa Ferraz Junior, proprietário da fazenda Água dos Bugres, em Cambará/PR. Foi ele quem articulou com outros fazendeiros a construção da Estrada de Ferro Noroeste do Paraná em 1923. Segundo D’ Ambrósio (2004), o trecho inicial de Cambará/PR a Ourinhos era de $29 \mathrm{~km}$. Como os custos foram altos, o Coronel Barbosa Ferraz procurou financiamento e novos sócios. Simon Joseph Frase, $16^{\circ}$ Lorde Lovat, barão inglês, membro da comitiva que negociava as dívidas brasileiras com seu país, se associou ao novo empreendimento. Esta parceria resultou na fundação da Brazil Plantations Syndicate Ltda, subsidiária da Companhia de Terras do Norte do Paraná.

No dia 20 de agosto de 1929, George Craig Smith, paulista, descendente de ingleses, partiu de Ourinhos - SP chefiando uma caravana de mais ou menos doze pessoas com destino às terras roxas do Norte do Paraná. Essa caravana iniciaria o desbravamento das matas, reconhecimento e loteamento da maior empresa colonizadora da América do Sul, dona de $\mathbf{5 0 0 . 0 0 0}$ alqueires de terras 
cobertas com matas virgens que impressionaram Lord Lovat em 1924. Em 1925 Lord Lovat, escocês, diretor da Sudan Cotton Plantations Syndicate e assessor de agricultura para assuntos de agricultura e florestamento foi constituído presidente da Paraná Plantations, versão inglesa da Companhia de Terras Norte Paraná (CTNP) [...] A Companhia de Terras Norte do Paraná colonizou uma área correspondente a 546.078 alqueires de terras, ou 1.321.499 hectares, ou ainda cerca de $13.166 \mathrm{~km}^{2}$. Fundou 63 cidades e patrimônios, vendeu lotes e chácaras para 41.741 compradores, de área variável entre 5 e 30 alqueires, e cerca de 70.000 lotes urbanos com média de $500 \mathrm{~m}^{2}$. Em 1944, a companhia passou a chamar-se Companhia Melhoramentos Norte do Paraná. ${ }^{10}$

Também foi a Companhia de Terras Norte do Paraná que

financiou a construção da estrada de ferro Noroeste do Paraná, cortando o loteamento das terras e das novas cidades. Esses acontecimentos permeavam a vida dos empreendedores, colonizadores, migrantes e imigrantes que vinham para estas terras, certos de que fariam fortuna e teriam novas condições de vida. ${ }^{11}$

Essa frenética corrida para as novas cidades do Paraná passava por Ourinhos e contribuiu para configurar outro aspecto da cidade, o comércio e a indústria. Foi essa nova oportunidade de se estabelecer em seu próprio negócio que atraiu imigrantes de diferentes nacionalidades para a cidade, com o predomínio de italianos, japoneses, sírio-libaneses, espanhóis, portugueses e um número não muito expressivo de imigrantes de outras nacionalidades os quais conferiram, à cidade e região, um caráter multicultural.

Tais conjunturas propiciam à região uma tessitura própria, contrariando a prática de aglutinação dos imigrados que permaneceram ou foram isolados das populações já existentes. Os estrangeiros fundiram-se com os pioneiros já estabelecidos e a cidade de Ourinhos se transformou em uma

\footnotetext{
10 Catálogo da Correspondência Ativa de George Craig Smith. Disponível em: <http://www.uel.br/museu/complementares/colonizacao.html>. Acesso em: 10 de agosto de 2007.

11 O modelo de colonização implantado no Paraná será repetido em novas regiões desbravadas como: Mato Grosso, Rondônia. Cidades planejadas tendo como guia rodovias, ruas largas e retas.
} 
fusão e hibridação de bens culturais tangíveis e intangíveis, em um mix de diferentes influências.

A presença de outras comunidades e culturas configurou 0 delineamento das características culturais da cidade, o de integração com o novo e o diferente que a distingue como pólo convergente de constante processo migratório e imigratório. Essa peculiaridade geo-econômico-social continuou a ser Implementada pela presença e construção de hidrelétricas e, mais recentemente, pela instalação de indústrias que começam a opor-se à cultura rural do bóia-fria no trato com a monocultura da cana-de-açúcar, iniciada a partir de 1950 e vinculada à indústria canavieira do álcool, atual cenário dominante na região.

A indústria canavieira foi também a responsável por outra leva de migração; desta vez, dos trabalhadores do campo para as periferias da cidade e, conseqüentemente, de trabalhadores rurais de outras regiões. Sua expansão demográfica tem início neste período. Subsistem, ainda, a cultura da lavoura do café e a criação de gado. Hoje, a cidade tem aproximadamente 109.229 habitantes, sendo 104.440 na zona urbana e 4.780 na zona rural, segundo dados fornecidos pela prefeitura local.

A diversidade cultural mencionada imprime à cidade e região uma de suas principais características: a aceitação e abertura para novas formas culturais. Por conseguinte, esta vocação também foi a porta de entrada para o seu desenvolvimento após a queda da produção do café que contribuiu, também, para o declínio das estradas de ferro no Estado. A decadência das estradas de ferro foi acentuada após a implantação da indústria automobilística 
no governo de Juscelino Kubitschek. A evolução acima exposta pode ser confirmada com a citação de Boscariol (2006):

De 1908 até 1940, encontramos um cenário predominantemente rural, [...] embora com uma passagem progressiva deste para o urbano. Em 1918, cerca de $75 \%$ da população encontrava-se na zona rural. Já em 1940, a proporção da população que se encontrava na zona rural cai para um pouco menos de $50 \%$ [...] Criam-se também pequenas indústrias para atender as demandas locais, como a indústria Migliari, que produz equipamentos agrícolas e máquinas para as olarias da Vila Odilon. Na cidade surge um comércio atacadista e armazéns, que estocam e distribuem as mercadorias que chegam através das ferrovias para as cidades da região [...] a segunda fase, que começa a partir da segunda metade da década de 1940, é marcada pelo processo de modernização e larga expansão da área urbana e da industrialização da agricultura, através, primeiramente, da cana-de-açúcar e, mais recentemente, da soja. [...] Em 1950, a população de Ourinhos alcançava 21.085 habitantes, sendo que a taxa de urbanização já se encontrava em $62 \%$, explicada pelo fato da população rural crescer mais devagar do que a população urbana. Este menor ritmo de crescimento se deve pela decadência da área rural, produtora de café e pela ação de um novo "ator econômico" na região, isto é, a produção canavieira. Esse fato acentua o êxodo-rural já que o latifúndio canavieiro não respeita limites e é um "devorador" de pequenas propriedades agrícolas.

O estudo acima exposto aponta para os mecanismos que

permitiram a sobrevivência e adaptação de um caldeamento de tradições e ações que sustentam a cultura da região, bem como possibilita compreender como o país reinventa seus processos de assimilação e acomodação de influências culturais, de conquistas e colonização. Ressalta ainda o caráter híbrido e a consciência cultural formada por bricolagem que estão na base do que constitui a formação e o desenvolvimento da cidade, da região e do país. 


\subsection{Os Povos Originários - Suprimidos e Esquecidos}

Nos relatos que se faz da colonização e adentramento da

"Boca do Sertão", pouco se fala dos povos originários ${ }^{12}$ que viviam na região.

Existem algumas referências do predomínio de coroado, guarani e xavante nas

fontes consultadas. Dantas (1980, p. 21-22-59) relata a existência dessas

mesmas tribos:

[...] habitavam a região três tribos indígenas: - os Coroados, nas vertentes do Rio do Peixe, dentro da mata; os Cayuás - (Guaranis) -, provenientes do Paraguai, nas vertentes do Rio Paranapanema (02) - ; e os Xavantes, ou Otis, originários de Mato Grosso, no plateau Central, região de campo e de Cerrados [...] (02) - CAIUAS: Segundo Hernâni Donato - (ACHEGAS PARA A HISTÓRIA DE BOTUCATU) - os Caiuá, ora mansos, ora enfurecidos, foram destruídos em sua taba principal, do outro lado da Serra de Botucatu, ás margens do rio Abaré-i, pelo desbravador da região do Alto Paranapanema, - José Teodoro de Souza e sua gente.

Nessa perspectiva, a cultura dos povos originários na região só é percebida quando se verifica os nomes de rios e de algumas cidades; exceto essas referências, ela é praticamente suprimida e sonegada. Por esse motivo, as fontes que subsidiaram este tópico foram obtidas em dissertações e teses acadêmicas não publicadas, pesquisas eletrônicas e na literatura que relata a formação da região; nessa literatura regional, muito pouco ou quase nada foi encontrado sobre as formas de viver e das contribuições culturais dos povos originários, e o que se relata está sempre carregado de preconceitos, adjetivos desqualificadores ou comentários pejorativos.

\footnotetext{
${ }^{12}$ A não existência dos povos originários e a ausência de dados confiáveis de suas culturas no estado e no país está suprimida dos estudos formais, principalmente, no ensino básico e superior. A inexistência dos povos originários só é percebida com a proximidade de datas comemorativas, como o "Dia do Índio". O desconhecimento dos povos originários é mencionado nesse trabalho para direcionar a análises que se pretende apontar: a formação e as influências das diferentes culturas que marcaram a formação do oeste paulista e seu desenvolvimento. Bem como, apontar para as contribuições das culturas subalternas na formação e alicerce das nossas características culturais. Nessa perspectiva, não foram encontradas significativas influências das culturas dos povos originários nas manifestações culturais nas comunidades da região.
} 
Portanto, segundo Mota (2000), pode-se afirmar que os povos originários dessa região procedem de duas tradições remotas: a Humaitá e a Guarani. A primeira ocupou os Estados do Sul Brasileiro e as regiões do que hoje compreende o Paraguai e Argentina entre 8.000 a 2.000 anos atrás. Não existem descendentes conhecidos dessa cultura, mas sabe-se que andavam em grupos e sua subsistência se dava através da caça, pesca e coleta de diferentes vegetais. Em levantamentos arqueológicos, foi detectada uma formação sócio-cultural organizada; viviam em abrigos construídos com vegetais da região (Palmáceas) ou rochosos; os vestígios coletados indicam características líticas de lascamento e com polimento. No Sul do Brasil, Uruguai e partes do Estado de São Paulo, é registrada a presença da tradição Umbu; suas características assemelham-se às dos Humaitá e os vestígios encontrados indicam uma origem mais antiga.

\footnotetext{
Esses vestígios foram datados entre 12.000 e 1.000 antes do presente, demonstrando a longa persistência dessa tradição nos mais variados ambientes da região [...] As pesquisas realizadas dessas tradições estão concentradas atualmente na margem esquerda dos Rios Paraná e Paranapanema. Pesquisadores dataram [...] que as mais antigas populações de caçadores/coletores não Guarani e Jê teriam adentrado na região há quase 7.000 anos, conforme datações C14 (Carbono 14) e termoluminescência obtidas por diversos pesquisadores [...] (MOTA, 2000, p. 3).
}

Quanto aos Guarani, alguns pesquisadores (NOELLI, 2000 apud MOTA, 2000, p.3) relatam que desceram a Bacia Sudoeste do Amazonas, adentrando no que hoje é conhecido como Paraguai, Uruguai e Sul do Brasil por volta "de 2.500 A.P. (Antes do Presente)". Outra cultura presente nos relatos apontados são os Jê - Kaingang e Xokleng - que levam essa denominação vinculada ao seu idioma. 
Na região Sudeste e Sul do país, os estudos apontam sua migração ocorrendo preferencialmente nos planaltos próximos aos Rios Paranapanema, Itararé e Ribeira. Também indicam que os Guarani sobrepuseram-se às localidades já habitadas pelos Kaiguangue, deslocando-os para outros territórios inter-fluviais. No final do século XVII, com o extermínio dos Guarani, os Kaiguangue encontraram oportunidade para uma nova expansão, principalmente onde se encontra o Estado do Paraná. Ambas as culturas possuíam o domínio da pedra polida e a fabricação de cerâmica para preparar alimentos. Esses vestígios são frequentemente encontrados nos trabalhos de pesquisa de campo dos estudiosos e por agricultores durante 0 preparo da terra com arados. No Estado do Paraná, eram localizados, até a década de 30 a 50, em aldeamentos próximos a São Jerônimo da Serra e Apucaraninha (Norte novo do Paraná). Quanto aos Xavante da região, pouco ou quase nada foi encontrado que esclarecesse sua presença nas fontes pesquisadas.

[...] as bacias do Paraná, Paranapanema, Itararé, Tibagi bem como seus afluentes foram densamente povoadas por [...] Umbu e Humaitá e pelos Guarani e Jê (Kaingang e Xokleng). Na época da chegada dos europeus na América, podemos dizer que os Guarani ocupavam além do litoral da baia de Paranaguá para o sul todos os vales dos grandes rios do interior, e os Jê (Kaingang e Xokleng) ocupavam as regiões mais altas nos interflúvios desses rios. (MOTA, 2000, p.7)

Os estudos de Mota apontam também que os Guarani estavam presentes em toda a extensão das proximidades do Rio Paranapanema, incluindo-se Salto Grande, Piraju e cidades próximas de Ourinhos e mantiveram relativa proximidade, nem sempre pacífica com os brancos, no período do Império. Os Kaiguangue, ao contrário, são descritos nos relatos 
históricos como guerreiros que defenderam suas ocupações de terras contra os Guarani e os brancos.

Atualmente, na cidade de Piraju, foi inaugurada em 2004 a Casa da USP/Piraju, principal desdobramento do Museu de Arqueologia e Etnologia (MAE), da Universidade de São Paulo (USP). A instituição realiza projetos na cidade e na região do Médio Paranapanema desde a década de 60 , levantando e documentando as culturas materiais dos povos originários. A Casa da USP configura um importante avanço para propiciar conhecimentos acerca desses povos em nossa região.

No Médio Paranapanema, durante as investidas de José Teodoro de Souza e de seus conterrâneos, há relatos das práticas de extermínio utilizadas no período as "dadas"13. Esses relatos ajudam a compreender por que a contribuição dessas culturas ou mesmo sua presença inexiste na região, mesmo tendo havido algumas legislações ou proposições do governo paulista para considerar a terra dos povos originários desde de que fossem, segundo Mota (2000), "catequizados e civilizados”.

Foi o Cel. Francisco Sanches de Figueiredo, de Platina, que organizou, sistematicamente, 0 combate aos indígenas, principalmente na zona do Rio do Peixe, em expedições a que se deu o nome de 'dada'. Das 'dadas' contam-se horrores: - enquanto se exterminavam, à bala, os selvagens, penetravam os brancos nas habitações para 0 ataque às mulheres e às crianças: - aos indiozinhos, levantavam do chão ou do leito, atiravam-nos para o ar e os espetavam na ponta da faca; outras vezes, tomavam-nos pelos pés e davam com suas cabeças em paus, até parti-las; rasgavam os ventres das mulheres grávidas [...] em 1904, homens de destaque da capital organizaram uma sociedade destinada a civilizar e proteger os silvícolas. Conseguiu Capuchinos para a Missão [...]. Acobertados pelos sertanejos, 'bulgreros' a missão investiu na mata ao encontro dos índios. Quando estes se apresentaram, os frades caminharam para eles, empunhando o Crucifixo. Mas os índios avançaram agressivos [...] e os frades, apavorados, imploraram aos sertanejos

13 Ataque, batida ou assalto organizado contra aldeias de índios (in Novo Dicionário da Língua Portuguesa, 2. ed, 44ª impressão, RJ: Editora Nova Fronteira, 1986) 
com um brado de socorro: ' - atirem nos selvagens, atirem nos selvagens!'. A Missão, destarte, se transformou noutra 'dada'. (DANTAS, 1980, p.40-41).

São comuns relatos do medo que os povos originários despertavam nas povoações e como eram maltratados e evitados quando detectados perambulando pelas precárias estradas, no tempo da colonização e desenvolvimento do Oeste Paulista. Durante a investida da Companhia de Terras Norte do Paraná, também foram muitos os confrontos e extermínio das culturas originárias. Esses fatos contribuíram para consolidar, nos escritos produzidos pelas camadas hegemônicas e no imaginário popular, a idéia de que os povos originários eram sujos, ladrões, preguiçosos, sem cultura e deveriam ser banidos do convívio da sociedade. Nos relatos obtidos através de entrevistas com os antigos moradores da região, essas idéias estão muito presentes. Além disso, Mota aponta também os inúmeros conflitos intertribais e com os brancos invasores, situação que configura "relações interculturais que vão além da simples polaridade índios versus brancos." (MOTA, 2000, p.29).

$\mathrm{Na}$ atualidade, a contribuição e o conhecimento das culturas dos povos originários ainda são desconhecidos e não fazem parte da formação e educação básica. Segundo dados obtidos no site do Instituto Sócio-Ambiental (ISA), em pleno século $X X I$, a grande maioria dos brasileiros ignora a imensa diversidade de povos originários que vivem no país. Estima-se que, na época da chegada dos europeus, fossem mais de 1.000 povos, somando entre 2 e 4 milhões de pessoas. Atualmente, encontramos no território brasileiro 227 povos falantes de mais de 180 línguas diferentes. A maior parte dessa população distribui-se por aldeias, situadas no interior de 593 "Terras Indígenas", de norte a sul do território nacional. Para o ISA a população originária no Brasil atual 
está estimada em 600 mil indivíduos, sendo que, deste total, cerca de 480.000 mil vivem em suas Terras (e, em menor número, em áreas urbanas próximas a elas), enquanto outros 120.000 mil encontram-se residindo em diversas capitais do país. Importante ressaltar que os dados do Instituto Brasileiro de Geografia e Estatística (IBGE), (Censo Populacional de 2000) indicam que a parte da população brasileira que se autodeclarou genericamente como “indígena" alcançou a marca de 734 mil pessoas, marca, portanto, superior à estimada pelo ISA. ${ }^{14}$

Segundo os dados do IBGE que constam do senso de 2000, no Estado de São Paulo estudos recentes apontam para uma população estimada em 63.789 de povos originários, vivendo em diferentes regiões, sendo que o maior contingente encontra-se na capital, assim como a maior variação de procedência. Os Guarani perfazem o maior número.

A Comissão Pró-Índio de São Paulo é uma das organizações que tem como missão articular a divulgação da cultura dos povos originários do Estado na atualidade e promover a sua integração com a sociedade. Acreditase que a convivência será o fator que desencadeará o reconhecimento da contribuição que esses povos podem oferecer. Procura, também, desencadear o intercâmbio entre eles e os diferentes segmentos da sociedade, para erradicar o preconceito existente em relação aos povos originários, que permeia a nossa história e atualidade. No Oeste Paulista, na região de Bauru:

encontram-se as Terras Indígenas Araribá, Icatu e Vanuíre, onde moram os Guarani, os Terena, os Kaingang e os Krenak, num total de 861 pessoas. A TI Araribá é a que possui a maior população: 525 habitantes, sendo 172 Guarani Nhandeva. As três Terras Indígenas já foram demarcadas e homologadas; no entanto, possuem dimensões

\footnotetext{
${ }^{14}$ Este parágrafo foi subsidiado com dados e informações obtidas no Instituto Socioambiental através de seu site. ISA - Instituto Socioambiental. Disponível em: <http://www.socioambiental.org/home_html>. Acesso em: 10 de Agosto de 2007.
} 
insuficientes para a reprodução física e cultural dos grupos indígenas que nelas habitam. As comunidades reivindicam a abertura do processo de revisão dos limites de seus territórios. ${ }^{15}$

Neste item, pouco se pode abordar quanto à real contribuição e condição cultural dos povos originários da região. Os dados encontrados ainda estão centrados em fontes numéricas e pouco esclarecem sobre os modos viventes dessas comunidades. A Casa da USP em Piraju, através de seu acervo, preserva parte da memória material desses povos; quanto a suas tradições, ainda se tem muito que aprender e conhecer.

Ao apresentar o mapeamento que delimita a localização dos povos originários do Estado de São Paulo, pretende-se apontar para a inexpressiva presença dessas culturas no Estado. O mapeamento e a disponibilização nos veículos eletrônicos não significa que essas culturas estão realmente sendo valorizadas, mas, sim, aponta para a sua presença "invisível na nossa cotidianidade". Nos livros de formação do ensino básico esses dados praticamente inexistem e não se detectaram propostas de valorizar e contemplar essas culturas nas diretrizes curriculares do estado. Os Parâmetros Curriculares Nacionais (PCNs) apontam para esse caminho quando indicam que é necessário a valorização e discussão, na escola, da diversidade cultural, mas as diferentes esferas de formação e fomento da valorização das culturas dos povos originários e subalternas do país não trabalham efetivamente para viabilizar o que é sugerido nos PCNs.

As instituições particulares de ensino básico e ensino superior, que poderiam direcionar o conhecimento das manifestações culturais dos povos originários, também são deficitárias quanto ao acesso e à condução dos

\footnotetext{
15 Dados obtidos através de pesquisa no site da Comissão Pró-índio de São Paulo. Disponível em: <http://www.cpisp.org.br/indios/index_all.html>. Acesso em: 9 de Agosto de 2007.
} 
conteúdos desenvolvidos. Portanto, o desconhecimento que professores e alunos possuem perpetuam as relações de extermínio dos povos originários.

Os dados, informações e mapas indicam que, na região do Sudoeste Paulista, os relatos de extermínio da cultura dos povos originários são verídicos; foram localizados três aldeamentos próximos a região de Ourinhos, indicados pelos itens 1,2 e 3.

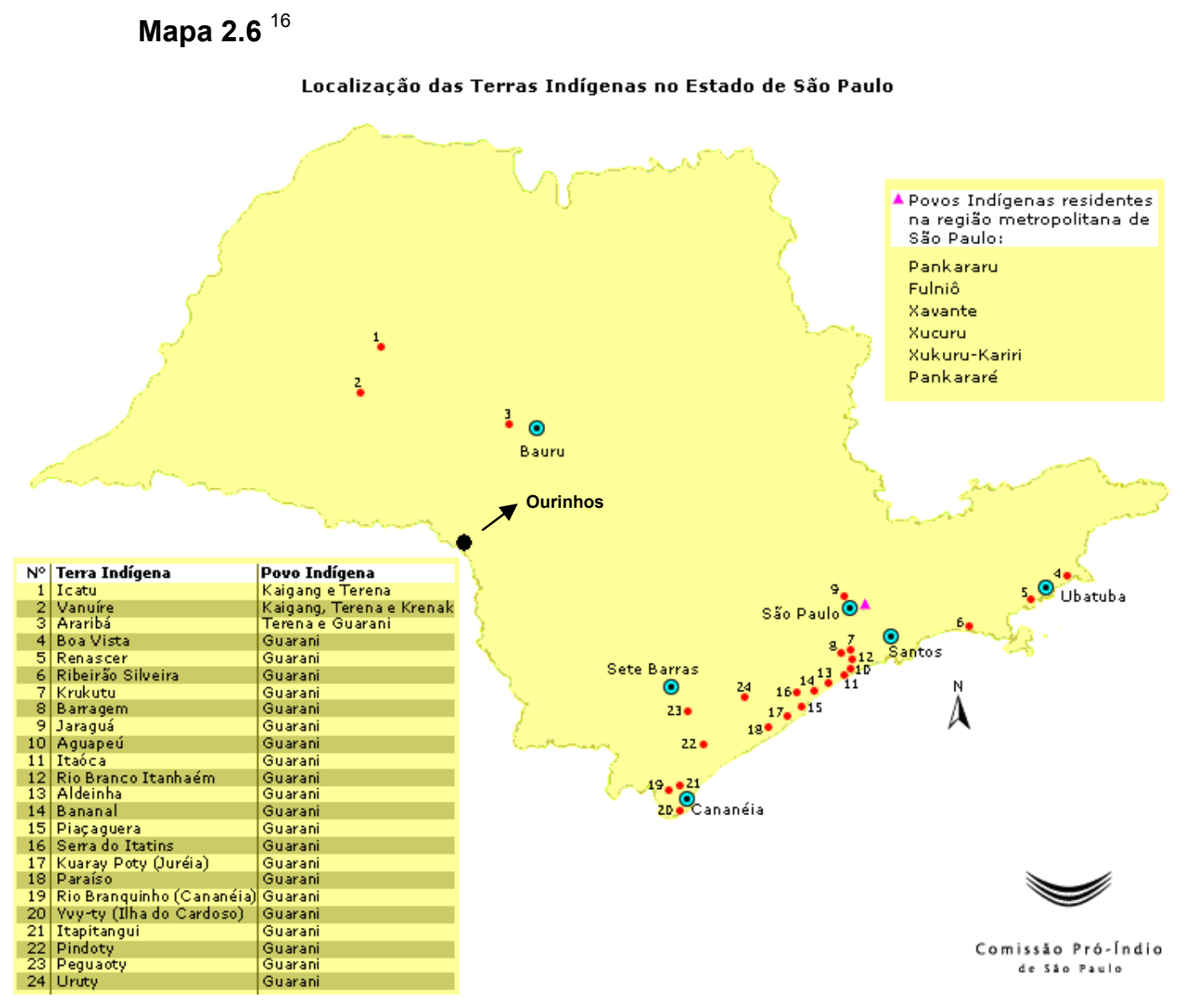

\subsection{O Colonizador}

Encontramos o ângulo obrigatório para se enfocar a nacionalidade naquilo que Simone Weil chama de enraizamento. Todo ser humano tem raízes em uma coletividade. País e raiz, mais do que rimas, formam um par indissociável. País é o chão em que se cresce, a paisagem que nos cerca, a sociedade que nos gerou e nos envolve

\footnotetext{
${ }^{16}$ A localização da cidade de Ourinhos foi acrescentada pela autora.
} 
uterinamente. Nessa sociedade não apenas se guardam tesouros do passado como se vivem também as indagações e o pressentimento do futuro. (VANNUCCHI, 2002, p. 43).

A trajetória de formação e colonização que caracterizou a formação histórica do país como um processo esmagador que suprimiu culturas, escravizou, introduziu povos, transplantou e acolheu outros migrados é apontada por estudiosos como desencadeadora de um processo de formação cultural ímpar e ainda pouco divulgado e explicitado, e as ações dos primeiros paulistas como condutores desse avanço, transforma os paulistas (bandeirantes) em mineiros e, após o adentramento na "Boca do Sertão", mineiros em paulistas.

A dinâmica de migração dos mineiros do sul do estado para a região estudada está na sua origem e interligada com os costumes e modos viventes das comunidades rurais, que apontam para as semelhanças encontradas nas festas como: a Congada, a Festa do Divino e Folia de Reis, permitindo traçar comparações e detectar elementos similares em ambos os estados.

A expansão da lavoura do café e a ampliação das colônias das grandes fazendas da região intensificaram o processo de migração do sul de minas e do norte do estado de São Paulo já "amineirado". Esse processo fortaleceu as tradições vindas com os primeiros colonos. Dessa forma, os traços mineiros na região foram intensificados, bem como serviram de modelo de sociabilidade para os novos imigrantes que chegavam, como os japoneses, italianos e sírio-libaneses.

Nas festas de casamentos e batizados, o apadrinhamento e os compromissos firmados entre os compadres eram mecanismos que 
possibilitavam o surgimento da solidariedade e a integração das diferentes culturas dos imigrantes com os migrantes que desbravavam a região. A religiosidade também foi um fator decisivo para intensificar as trocas culturais dos diferentes grupos. A missa aos domingos sempre foi um acontecimento, quando era possível ir para as cidades ou reunir-se nas capelas das fazendas; conseqüentemente, a promoção e participação nas festas e quermesses eram concorridas e animadas, propiciando a todos se inteirarem das novidades, dos amigos. Outro aspecto que deve ser mencionado - e que marcou a constituição da região - foi o emprego reduzido de mão de obra escrava ou de afrodescendentes.

Das observações e entrevistas realizadas, foi possível detectar dois traços étno-culturais que predominaram na região: os mineiros e italianos e, na cidade de Ourinhos, soma-se ainda a presença dos japoneses.

A cultura mineira está presente no cotidiano das casas e modos de viver, como: a religiosidade vivenciada nas procissões vinculadas aos Santos padroeiros das paróquias da cidade e o espírito festivo presente nas quermesses, as comemorações da Semana Santa e também as procissões de Corpus Christi que mobilizam todas as paróquias da cidade, promovendo um evento único. Preparativos acontecem desde a véspera da procissão nos bairros e centro da cidade, envolve vários segmentos, desde escolas, clube de serviços e esferas públicas como departamento de trânsito, policiamento e manutenção da limpeza pela prefeitura; a "mineirice" está presente também no cardápio do cotidiano da maioria da população como: o arroz, feijão muito temperado, couve e carne; na apreciação de música 
sertaneja; nas formas de lida com a terra nas pequenas propriedades; nas crendices.

Os italianos trabalharam na lida do café em pequenas propriedades e nas grandes fazendas. Como afirma Massei (2001), também eram deles as olarias que marcaram a paisagem da cidade com suas torres arredondadas, provocando uma iluminação fantasmagórica, à noite, em decorrência do brilho dos fornos, "os olhos de fogo" utilizados para a queima das cerâmicas. Foram mais de 100 no auge de sua produção; eram vinculadas à fabricação de telhas e tijolos para suprir a demanda das novas construções da cidade, região e do Paraná.

A maior parte das olarias estava e está situada na vila Odilon. "Agrupados na vila Odilon, bairro isolado do núcleo central da cidade por uma extensa avenida", Boscariol (2006). Hoje o bairro atende as comunidades de outros núcleos populacionais do seu entorno. Sempre possuiu vida própria. Festas, igrejas, escolas e um bom comércio são motivos de agregação da comunidade e do seu bairrismo. Os mais antigos contam sobre as memoráveis (richas) nos bailes e nos jogos de futebol. Os jovens do núcleo central da cidade e de outros bairros, como a Vila Margarida, chamavam os moradores da Vila Odilon, pejorativamente, de "índios". Essa vila quase configurou um distrito da cidade; sua separação pode ser sentida na formação das estruturas culturais do bairro. Possuía um clube onde se promoviam animados bailes (arrasta-pés); a quermesse de Santo Antônio, padroeiro da paróquia, ainda é muito concorrida.

A comunidade japonesa é grande na cidade, sua presença pode ser notada, principalmente, nos produtos consumidos para preparo de 
sua culinária, presentes em todos os estabelecimentos de comércio de alimentos, principalmente nos hortifrutas, e influenciou a culinária local. Possui uma sede recreativa bem estruturada e organizada - "Kai-Kan" - Associação Esportiva e Cultural de Ourinhos (AECO). Essa associação promove diversas atividades incorporadas ao calendário de comemorações da cidade, entre as quais: a venda de Yakissoba, em parceria com o Fundo Social de Solidariedade, na Feira Agropecuária e Industrial de Ourinhos (FAPI), considerada uma das maiores feiras do estado, e o tradicional jantar em parceria com a Associação dos Engenheiros de Ourinhos (AERO), o "Sukiyaki”, também com fins beneficentes. Essas e outras promoções em parcerias exemplificam como a colônia é integrada na comunidade. Merece destaque a grande festa junina que acontece em sua sede, incorporada ao calendário das comemorações da cidade.

A AECO mantém uma intensa programação interna de atividades culturais, como concursos de Karaokê, comemorações do dia dos Pais, dia das Mães, o "Bon Odori"17. Essas festividades atraem para a cidade a comunidade japonesa das cidades vizinhas.

O clube possui duas sedes, uma na cidade e outra mais afastada, o clube de campo, onde acontece o "Undo Kai"18. A sede campestre possui, ainda, campo de Beisebol e quadra de Gateball. A colônia trouxe para a cidade escolas de língua japonesa, templos de diferentes religiões de origem japonesa, a prática de esportes, como Judô, Caratê (karatê), Tae-kwon-do,

\footnotetext{
${ }^{17}$ Festival de dança típica japonesa vinculada à comemoração e reverência - no Japão - aos antepassados.

${ }^{18}$ Tradicional festa nipônica vinculada ao $1^{\circ}$ de Maio nas cidades onde a colônia se estabeleceu. É uma grande gincana que integra todos os participantes, uma confraternização entre a colônia e a comunidade, uma pausa do trabalho e da lida no campo para o lazer coletivo.
} 
Xadrez Japonês e Tênis de Mesa ${ }^{19}$. Incorporou, nas características urbanas, praças, como a Praça das Cerejeiras e monumentos; está integrada no comércio, mas conserva, ainda, a lida no campo em pequenas propriedades. Atualmente trabalham também com granjas de ovos, concentradas no bairro rural Novo Mundo.

\subsection{Os interesses Hegemônicos e os Subalternos}

A expansão da lavoura cafeeira, no Oeste Paulista, atrelada à construção da estrada de ferro, foi decisiva para desenvolver uma sociedade e uma cultura dominante pouco comprometida com as tradições e manifestações culturais populares. A busca pelo novo que impulsionou o crescimento da cidade contribuiu para sua rápida inserção nos processos modernizadores do início do século passado. Nesse processo, a cultura e o lazer incorporaram elementos próprios da cultura de massa, como o cinema. A cidade de Ourinhos, desde seus primórdios, sempre teve salas de cinema e de teatro; foram ativadas e desativadas várias vezes e alojaram-se em diferentes edifícios. Nas décadas de 30 e 40, chegou a ter três salas de cinemas.

Também não se verifica entre suas lideranças a consciência da necessidade de preservação dos bens materiais e culturais, como as primeiras construções. A dinâmica dos que implementaram a evolução da cidade está impregnada da necessidade de ter sempre o novo - demolir para construir.

\footnotetext{
${ }^{19} \mathrm{O}$ atleta Gustavo Tsuboi, que conquistou a medalha de ouro no Pan-americano de 2007 é de Ourinhos e treina na cidade.
} 
Esse lema faz parte do seu dia-a-dia. Outra característica foi sempre a facilidade de locomoção que sua localização geográfica lhe confere. Ter contato com as inovações e modismos da metrópole paulista foi e é muito fácil; as comodidades e avanços tecnológicos são rapidamente incorporados no seu modo de vida. Outro fator desencadeador de sua constante aceitação pelo novo provém do fato de muitos dos seus investidores não terem residido na cidade; portanto, esses empresários não mantinham vínculos com seus habitantes e com suas tradições: não cultivavam laços de amizades e afetivos, seus relacionamentos eram somente vinculados às atividades econômicas. Desta forma, a história de Ourinhos e o patrimônio material e imaterial não Ihes pertenciam e não lhes pertencem.

As pesquisas apontam para uma característica notada por muitos que visitam a cidade, uma forte tendência festiva; o calendário de festas do município contempla praticamente todos os meses do ano. É uma cidade hospitaleira, recebe sem reservas os migrantes e os visitantes. Essa atitude lhe valeu o epíteto de "cidade do coração de ouro".

As festas populares manifestam-se nos bairros afastados e nos bairros rurais remanescentes. São acontecimentos anônimos, que não estão registrados nos eventos oficiais da cidade; nem são comentados nas escolas e comunidade cultural. Essa dinâmica é conseqüência das relações de poder e dominância estabelecida na formação histórica do município, onde o povo não era considerado, os mandatários e proprietários das grandes fazendas de seus primórdios não residiam na cidade, as lideranças não eram construídas a partir das comunidades já estabelecidas, pois vieram de fora, como é o caso dos ingleses que implantaram as ferrovias. E criou-se um apartheid, de um lado o 
povo constituído pelos migrantes e imigrantes, ávidos para se estabelecer e edificar um patrimônio que lhes possibilitasse viver melhor, gestando uma cultura solidária e híbrida em todos os sentidos, e de outro, uma minoria, proprietária das terras e dos empreendimentos que fixaram os lucros em outros lugares, como a capital e o exterior, construindo uma cultura com características importadas, como os cinemas e teatros.

É curioso notar que existe uma estrutura cultural forte na cidade, na atualidade. Ela possui um dos maiores e mais bem equipados teatros da região, duas salas de cinemas e uma escola municipal de bailado e música - Centro Cultural Tom Jobim - que atende mais de 1.800 alunos gratuitamente. Seu corpo de bailarinos é destaque em apresentações no país e no exterior. O Centro Cultural também realiza um Festival de Música conhecido nos meios eruditos e mantém uma Orquestra Sinfônica. A cidade possui várias instituições e escolas particulares de promoção cultural. Hoje, o Centro Cultural, mantido pela prefeitura, estabelece um trabalho com todos os segmentos da sociedade.

Contudo, apartada de todas essas atividades, nas periferias, germina uma cultura desconhecida, que se solidariza com os migrantes provenientes do corte de cana, o bóia-fria, bem como, com os que transitam nas associações de bairros, festas e quermesses das igrejas e praças de seus bairros.

Darcy Ribeiro, em sua fala Sobre o Óbvio na reunião da Sociedade Brasileira para o Progresso da Ciência (SBPC) em São Paulo em 1977, tece considerações que atiçam a necessidade de repensar e relatar a história, para fazer aflorar, urgentemente, a história e a cultura dos subalternos: 
Assim é que, desde então, lamentavelmente, já não há como negar dois fatos que ficaram ululantemente óbvios. Primeiro, que não é nas qualidades ou defeitos do povo que está a razão do nosso atraso, mas nas características de nossas classes dominantes, no seu setor dirigente e, inclusive, no seu segmento intelectual. Segundo, que nossa velha classe tem sido altamente capaz na formulação e na execução do projeto de sociedade que melhor corresponde a seus interesses. Só que este projeto, para ser implantado e mantido, precisa de um povo faminto, xucro e feio. Nunca se viu, em outra parte, rico tão capacitado para gerar e desfrutar riquezas, e para subjugar o povo faminto no trabalho, como os nossos senhores empresários, doutores e comandantes. Quase sempre cordiais uns para com os outros, sempre duros e implacáveis para com subalternos e insaciáveis na apropriação dos frutos do trabalho alheio. Eles tramam e retramam, há séculos [...]. A primeira evidência a ressaltar é que nossa classe dominante conseguiu estruturar 0 Brasil como uma sociedade de economia extraordinariamente próspera. Por muito tempo se pensou que éramos e somos um país pobre, no passado e agora. Pois não é verdade. Esta é uma falsa obviedade. Éramos e somos riquíssimos. [...] A verdade verdadeira é que, aqui no Brasil, se inventou um modelo de economia altamente próspera, mas de prosperidade pura. Quer dizer, livre de quaisquer comprometimentos sentimentais. A verdade, repito, é que nós, brasileiros, inventamos e fundamos um sistema social perfeito para os que estão do lado de cima da vida [...] (RIBEIRO, 1978, p. 9-22) ${ }^{20}$

A história de Ourinhos e região refletem os acontecimentos que

forjaram o sentido de povo brasileiro, precisamente o enfocado por Darcy

Ribeiro (1995), quando afirma que o Brasil é um país continental que deixa transparecer em cada localidade uma mescla cultural tão ampla e profunda que chega a ser improvável abarcar esta complexidade de diferentes tramas. Desta forma, ao se relatar a história desta cidade e da formação da região, está se explicitando em uma escala micro todos os acontecimentos que compuseram a existência e o desenvolvimento do país.

Fala-se de cultura "indígena" - povos originários -, mas as pesquisas e bibliografias existentes são de conhecimento de grupos restritos da academia; fala-se de contribuição européia, mas esta contribuição é apresentada somente pela ótica do dominador, ideologicamente compactuado

\footnotetext{
${ }^{20}$ A transcrição da fala de Darcy Ribeiro na reunião do SBPC foi retirada da revista Encontros com a civilização brasileira. Rio de Janeiro: Civilização Brasileira, v.1, p.9-23, 1978.
} 
com o eurocentrismo. As culturas afro e dos afrodescendentes são ignoradas. Fala-se de imigração e migração somente pelos dados estatísticos e numéricos. Desconhece-se o que pensava e sentia e o que pensa e sente o homem que migrou e imigrou. Fala-se de desbravamento da região, mas não se conhece como e o que se desbravou.

Nossas tradições e heranças foram deliberadamente empurradas para o esquecimento ou para a inércia do desconhecimento. Esquecer e desconhecer são conjugações que desmobilizam e descaracterizam as comunidades. Vários fatores trabalharam e trabalham para esse processo ser implementado na sociedade brasileira, e para nela se introduzirem valores alienantes que corroboram para suprimir, de forma muito rápida, os processos de construção do que poderá ser visto e entendido como cultura brasileira.

Na região estudada, em sua curta história - a maioria dos municípios não possui 150 anos de anos de existência - esses valores alienantes e alienígenas são fatores que colaboram para desencadear uma total amnésia de sua origem. Os fatos e as pessoas que estruturaram seu surgimento e existência são desconhecidos; a própria dinâmica dessas comunidades que estão permanentemente vinculadas às mudanças que caracterizaram o final do século $X I X$, o século $X X$, bem como o tempo presente, as transforma em comunidades que têm a atenção voltada somente para o amanhã, o vir a ser. É preciso construir, obter lucros, recuperar os investimentos. Tudo está por fazer, não existe o tempo para olhar o já feito, o já construído, o já existente. Esta sociedade sem memória, sem história, pode estar condenada a ser uma eterna peregrina em busca de conquistas, eternos 
desbravadores moendo tudo que encontram pela frente. $O$ processo de globalização e a difusão do pensamento neoliberal, dualidade atual, transformaram-se em perfeita combinação para selar esta conjuntura de esquecimento, promovem e negam o aprendizado com os erros e acertos do passado. E, sem passado, sem oportunidade para visitar a memória, as culturas estão destinadas à extinção.

A diversidade cultural apontada na formação da cidade de Ourinhos e região impõe, desta forma, uma urgente necessidade de elaborar registros fundamentados em teorias que valorizem e contemplem toda a riqueza produzida e encontrada nas manifestações das diferentes culturas que a formaram.

Não se tem a ambição de abarcar toda essa complexidade, mesmo porque, não caberia neste trabalho; objetiva-se abordar e apontar questões que estão suprimidas dos textos pesquisados, até então, referentes à região, como a contribuição das culturas subalternas para a formação do ethos cultural da cidade e da região através de suas festas. Pretende-se, portanto, filtrar, das fontes existentes, subsídios para desvendar as contribuições das culturas subalternas na promoção e perpetuação das festas que permeiam as comunidades da região.

Para tanto, será preciso explicitar de forma dialética os processos de sua formação histórica e valorizar as micro histórias, que são espelhos do macro, no contínuo processo de formação cultural. Nessa concepção de micro está também subentendida a história do homem anônimo que transita pelos grandes acontecimentos sem ter voz nesse processo. É esse anônimo, no entender deste trabalho, o portador e detentor das matrizes 
das culturas populares, subalternas e agente construtor dos grandes acontecimentos históricos e culturais. Para procurar nas fontes históricas disponíveis as contribuições das culturas subalternas, é necessário recontar as micro histórias dialeticamente, a fim de dar visibilidade aos protagonistas do objeto de estudo a que se propôs este trabalho — os Foliões das Festas de Reis. 


\section{AS FESTAS}

\subsection{Festa}

Festa é, portanto, consumação, dispêndio, sacrifício, troca-dom, reciprocidade, ou seja, o ato mesmo de produção da vida. [...] E começa como libertação do social, como troca-dom, como um outro nós. [...] A festa é o espaço da novidade, do encantamento, da alucinação. Ela nega a carência, a precariedade, sem negar a realidade [...] (PEREZ, 2003, grifo da autora).

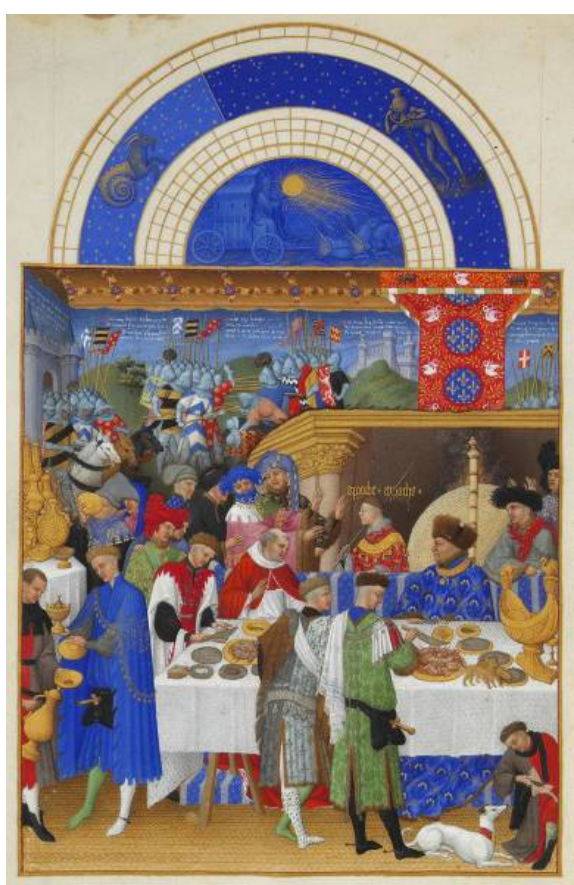

Imagem 3.1: Les Très Riches Heures du Duc de Berry ${ }^{21}$

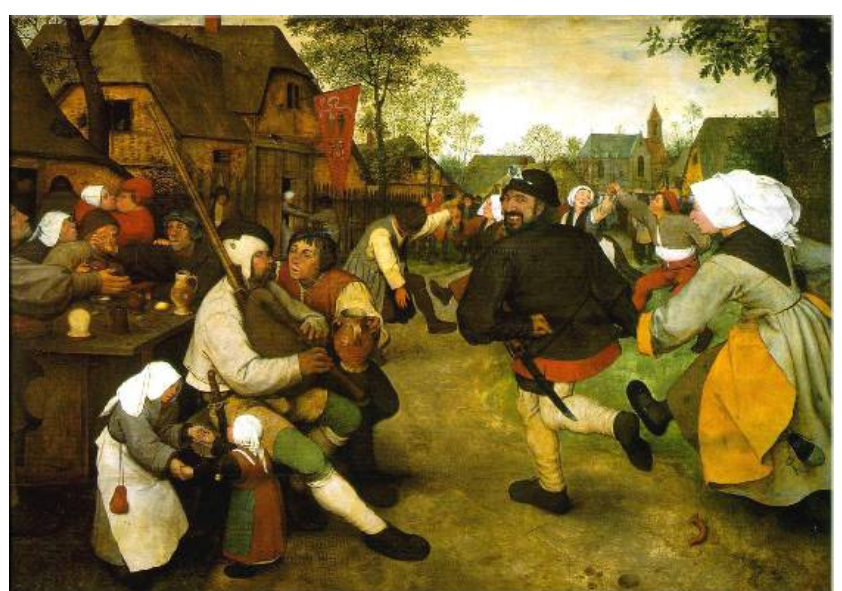

Imagem 3.2: Pieter Brugel. A dança dos camponeses. Kunsthistorisches Museum, Viena. ${ }^{22}$

Nas representações plásticas mais antigas do homem já se

registram atividades festivas, portanto, desde tempos imemoráveis, elas já organizavam e demarcavam as atividades dos grupos sociais, agregando-se e

21 Miniatura do livro de horas Les Très Riches Heures, encomendado pelo duque de Berry, aproximadamente em 1410. Disponível em: <http://www.iluminura.blogs.sapo.pt/8254.html>. Acesso em: 05 de outubro de 2008.

22 Disponível em: <http://www.famousartbydee.com/roomtwo.html>. Acesso em: 05 de outubro de 2008. 
articulando-se com a cultura de cada povo. Compartilham com todos os membros do grupo as expectativas de elaboração e participação, unem o eu individual e o eu coletivo - o ethos - através da magia e do real.

As festas vinculam as comunidades com o inexplicável, com o que a terra dá: as colheitas e com o que a própria natureza tira: a morte ou destruição. Em muitas comunidades existem celebrações vinculadas à morte que adquirem caráter festivo, articulam-se com a necessidade de agradecer e também de pedir proteção. Portanto, desde seus primórdios, estão atreladas ao que é produzido pelo trabalho ou com as dádivas da natureza e acompanha a própria dinâmica de sobrevivência dos grupos e do homem com a dinâmica de dominação e domesticação da natureza, com o trabalho e as formas de produção.

Revelam, ainda, a cultura e memória dos povos. A festa é um conjunto de cerimônias e rituais, religiosos ou não, que confirma laços sociais. Nela as emoções e as lembranças são ativadas. Em diferentes lugares, mantém características semelhantes, como as manifestações do canto, da dança, da música e, principalmente, com os elementos etnográficos e iconográficos que a caracterizam. Desencadeia uma catarse coletiva que fortifica as comunidades, preparando-as para continuarem seguindo seu cotidiano.

As festas traduzem as múltiplas linguagens das culturas subalternas e das culturas hegemônicas, tornam visível o que vem da mais íntima forma de ser e pensar: "a alma de um povo".

As festas, através de seus rituais e práticas longínquas usadas para ordenar a dinâmica do tempo e do espaço, acompanham os calendários 
de cada cultura, propiciam sentido às ações da cotidianidade necessárias para equilibrar a dialética entre o ser e o fazer, segundo Ferreira (2006), e tornamse, desta forma, importante objeto de estudo; passam a possuir uma profunda interação com a cultura ou categorias de cultura, da mesma forma que se transformam em fatos sociais, históricos e políticos de acordo com Itani (2003), e se convertem em representantes da cultura de um povo.

São fatos sócio-comunicacionais-culturais, estruturas imutáveis e ao mesmo tempo mutantes, seus elementos e composição são repetidos ao longo dos séculos, mas incorporam constantemente em seu desenrolar as novas informações da evolução cultural e tecnológica do homem e das sociedades onde estão inseridas, são iguais e ao mesmo tempo desiguais. Seu caráter coletivo pode alcançar uma nação, país, como pode estar restrita a pequenas comunidades; são religiosas, profanas, cíclicas, móveis, públicas ou privadas.

$\mathrm{Na}$ atualidade, as festas são poderosos veículos comunicacionais que cumprem dupla função: salvaguardam as práticas ancestrais e as origens culturais das comunidades, assim como as articulam para que possam conviver, assimilar, selecionar e acomodar as informações dinâmicas e tempestivas trazidas ininterruptamente pelos meio massivos de comunicação.

Imbricadas nas comunidades, as festas são fatos sociais intrincados, possuem conjuntos de cerimônias, de rituais coletivos, presentes em celebrações de cunho religioso ou profano, e se conservam em função da colaboração de toda a comunidade, que se mobiliza para sua organização e, posteriormente, vivencia unida sua realização. A dinâmica de toda festa é um 
complexo de relações onde todos são atores e espectadores, produtores e consumidores; ela é performática. Nas festas, as relações comunicacionais se dão na sua amplitude e completitude: na formulação dos mecanismos de organização primária de gerar as idéias, na articulação de sua estruturação e organização, na sua divulgação, na sua realização, na receptividade do fato e no seu vivenciar posterior.

No tempo das festas, o dia-a-dia é suprimido e um outro tempo é inventado, uma realidade paralela coabita com a comunidade, onde o imaterial, o imemorável, o imencionado e o incomensurável se fazem presentes nos rituais, os sentimentos e emoções mais profundos são expostos, assim como as reentrâncias das tramas das relações sociais da comunidade são expurgadas.

\begin{abstract}
A festa é uma necessidade social em que se opera uma superação das condições normais de vida. (...) A festa é a expressão de uma expansividade coletiva, uma válvula de escape ao constrangimento da vida quotidiana. Da economia passa-se à prodigalidade; da discrição à exuberância. Surgem as manifestações de excesso, nos mais ricos por ostentação, nos mais pobres por compensação. (BIROU, 1966, p.166).
\end{abstract}

Desde as pequenas células de convívio com a família, aos grandes núcleos sociais, a essência das festas está presente - o viver e conviver com o outro - mesmo quando adquirem aspectos coletivos que transcendem regiões ou nações, continuam atreladas a grupos menores que promovem sua organização ou a instituições que gerenciam e organizam as sociedades, como Igrejas, escolas, associações.

Esses vínculos são uma via dupla que atrelam as festas aos mandatários e ao submisso, à cultura hegemônica e à cultura subalterna. Portanto, sua efetivação passa por várias esferas das camadas da sociedade, 
depende de uma comunhão entre opostos e semelhantes e, desta maneira, reúne em suas realizações atitudes e negociações políticas, arranjos culturais, planejamento econômico. Essas atividades perscrutam todos os processos comunicativos, antes, durante e depois de sua realização, como já mencionado, bem como da relação de indivíduo para indivíduo, indivíduo para grupo e vice versa e, ainda, explicita uma relação intra e inter pessoal. Também se apresenta como mediadora da apropriação de novas tecnologias pelas comunidades e como desencadeadora de relações com grupos maiores, utilizando-se dos canais massivos de comunicação da atualidade.

A premente necessidade que a articulação das festas desencadeia faz com que o imaginário coletivo se funda com os desejos individuais. Elas são, ainda, um aglutinador de relações entre os parentescos, dos moradores das ruas e bairros com as diferentes instituições sociais. É nelas que as reconciliações com os membros da coletividade e com a materialidade e a imaterialidade se concretizam.

As festas trabalham, ainda, com as imagens psíquicas do indivíduo e da sua coletividade, os arquétipos presentes no inconsciente coletivo, no sentido que Jung (1964) os concebeu: as heranças das vivências e impressões das gerações que nos antecederam. É o acúmulo de sentimentos, pensamentos e lembranças, da evolução da humanidade, trocados no desenrolar da história.

Arquétipo vem do grego "arkhétypos" e remete para o modelo primitivo, para a gênese inata dos indivíduos e sua coletividade, projetada através de imagens latentes, primordiais. Os arquétipos que constituem o inconsciente coletivo são imutáveis e estão presentes em todas as culturas e 
indivíduos. Sua manifestação se faz através dos símbolos, ou linguagens simbólicas, pelas representações visuais desses símbolos a iconografia, ou ainda pelas mensagens subliminares. Desta forma, as festas carregam essas lembranças arquetípicas e reorganizam a psique coletiva e individual. Se o mito, para Jung, é a conscientização dos arquétipos, as festas com todas as suas simbologias podem ser suas materializações, tornando-se personas coletivas que representam o imaginário e os desejos de todos, carregam a história de uma comunidade.

Portanto, não é possível olhar as festas por elas mesmas; mas sim, para as realidades que elas projetam no e do social. A festa revela a verdade das relações coletivas e individuais; nela ficam transparentes os desejos, as relações com o cognoscível e o incognoscível através de imagéticas mentais e concretas. Nesse sentido, todas as festas são acompanhadas de ritos ou de dramatizações, realizações performáticas imagens gestuais - bem como de objetos simbólicos e imagéticos.

As festas são iconograficamente perpetuadas através de seus rituais, objetos e práticas, secretas ou não, objetos muitas vezes celebrados e confeccionados sem o conhecimento exato do porquê de sua realização e construção, práticas herdadas e passadas pelas gerações de formas repetitivas, usadas para ordenar a dinâmica do tempo e do espaço, propiciando sentido às ações da cotidianidade.

Estão diretamente articuladas com o cotidiano e indissociadas do lúdico, do descanso, da pausa para recuperar o fôlego e seguir com a rotina do viver. Marcam a relação do homem com os ciclos da natureza, do tempo e das dinâmicas que cooperaram para perpetuar sua subsistência, sobrevivência 
e modos culturais. Também celebram sua relação com o incognoscível, por isso, geralmente, são cíclicas e marcam momentos importantes das comunidades, muitas vezes estão vinculadas às estações do ano, principalmente, nos países onde o inverno é rigoroso e a subsistência era e é fator importante.

A festa é um ato que não acontece por um único indivíduo, não é um fato comum, e ainda que marque momentos temporais, carrega atemporalidades e se distancia da lógica cotidiana. Nela é possível encontrar diferentes atitudes que se fundem como o estado de exaltação, coletivo e individual. É um momento de celebração e consagração com seu semelhante ou através de objetos simbólicos fazendo com que uma realidade paralela aconteça no tempo de ser e viver, é uma virtualidade de um outro tempo ou acontecimento. Desta forma, a espacialidade sugerida e necessária para a realização da festa e transcende o real, penetra no lúdico, na fantasia e no sagrado.

As histórias das celebrações festivas sempre estiveram marcadas nas diferentes comunidades pela presença de um prazer individual compartilhado com o coletivo - hedonismo - bem como pela exaltação e celebração da vida. As festas caracterizam-se, então, por instaurar uma ordem temporal e uma outra espacialidade que transgride as normas e a espacialidade do cotidiano. Conduz para o surgimento de uma outra ordem coletiva.

Toda festa também é um espelho sacralizado do cotidiano; portanto, nela são encontradas atitudes profanas e sagradas que religam 0 indivíduo e a comunidade. Nela seus participantes são personas, atores de 
uma outra realidade, mas são também viventes da realidade concreta da comunidade. Desta forma, são nas festas, travestidos de agentes organizadores ou participantes, que os membros das comunidades deixam transparecer através de atividades lúdicas uma crítica da sua realidade social.

Neste sentido, os elementos iconográficos que caracterizam as festas são manifestações estéticas próprias das comunidades onde acontecem e são manifestações únicas, nascidas geralmente na própria comunidade e que perpetuam, muitas vezes, elementos que transcendem o tempo e espaço. Nesta plasticidade, transparecem outras épocas e outros lugares visitados pela atualidade.

Festa é, por conseguinte, realização, construção, sacrifício, permuta, dádiva, sintonização; consiste em existência, em vivência, em partilha com semelhantes. A festa é uma caixa de memórias; nela, a história é revivida e projetada para o futuro; é assegurada a manutenção das tradições, dos atos iniciáticos que ordenam as regras das comunidades, os elos reguladores das culturas.

Ao longo do processo histórico de desenvolvimento do homem e de suas comunidades, as festas sempre foram formas de marcar momentos iniciáticos de sua formação psíquica e social, presentes nos ritos de passagem quando o homem assume tarefas que irão colaborar para a perpetuação do grupo, como no nascimento, casamento e morte.

Na festa, o impossível se torna possível, é um campo virtual e experimental das relações e dos sentimentos do indivíduo e da coletividade. Neste campo de experimentações a festa se faz e os juízos emitidos de uma festa são sempre parciais, ela atende ou não as expectativas nela depositadas, 
é sempre acontecimento catártico de expiação ou êxtase das necessidades

interiores do indivíduo ou da coletividade. Nela, os desejos, intenções, sonhos

e necessidades são materializados, são virtualizados e, conseqüentemente, também o deslumbramento e o arrebatamento são vividos. Esses sentimentos são vivenciados de forma única por cada participante; é nesse frenesi que a festa se desencadeia em cada um e na comunidade. Desta maneira, a ordem social é momentaneamente rompida e o tempo invertido ou estancado.

Por tudo isso a festa é um campo multi e interdisciplinar de estudos e pesquisas. Nesse sentido, Léa Freitas Perez (2003) explicita na conclusão de seu artigo:

\begin{abstract}
O estudo da festa permite que transitemos por territórios da vida coletiva que, dado seu caráter extra-ordinário, extralógico e extratemporal, revelam toda a complexidade do fato societal, uma vez que a festa 'faz entrar a sociedade em uma relação consigo própria diferente daquela de 'todos os dias'.Para a infirmar ou para a confirmar, para a fazer existir num duplo que poderá ser ela própria ou outra, ela própria e outra' (SANCHIS, 1983: 36). A festa possibilita, assim, que visualizemos, sob um outro ângulo, o espetáculo plurívoco do elo societal, sobretudo no que tange à acentuação do afetivo e do sensível. O estudo da festa permite redimensionar essa discussão na medida em que, sendo um 'fenômeno vindo do fundo da tradição', e que, em relação à contemporaneidade mais imediata, possa parecer alguma forma de arcaísmo, de sobrevivência, de nostalgia, ou até mesmo de atraso, é, no entanto, vivida, por aqueles que dela participam, como explosão de vida, como revigoramento e, portanto, como uma espécie de renascimento, pleno de atualidade, de inovação, de ruptura. Para quem participa dela, a festa não tem idade, é sempre atual.

[...] A festa não é um mero produto da vida social, muito menos um simples fator de reprodução da ordem estabelecida pela via da inversão. Tal como o princípio de reciprocidade, não custa repetir mais uma vez, a festa é o ato mesmo de produção da vida. E viva a festa!
\end{abstract}

Além disso, é possível ver nas festas uma profunda simbiose com as culturas ou "categoria da cultura", através de dois aspectos importantes:

O primeiro deles é a capacidade que a festa tem de trazer para a atualidade, desde longínquas épocas, as experiências culturais 
vivenciadas por determinada população; o segundo aspecto refere-se ao fato de que, mesmo contrariando as práticas intencionalmente concebidas no momento da festa, os usos e costumes mais profundos vivenciados pela cotidianidade e entranhados no inconsciente afloram, mostrando a verdadeira face de um povo, moldada através da cultura. (FERREIRA, 2005, p.72).

Portanto, ao direcionar os estudos para as festas das culturas

subalternas, buscou-se desvelar a cultura dentro da sua mais genuína manifestação. Conforme Ferreira, nela é possível verificar as relações que fortalecem os "laços sociais identitários", e são, ainda, manifestações que:

[...] ultrapassando a barreira do tempo, enfrentando diversas dificuldades de diferentes aspectos, vivenciando intensos processos de aculturação, de sincretismo e mesmo de proibições, prevalece até a atualidade numa reafirmação da cultura como força propulsora de processos civilizatórios integradores e, também, como poderoso instrumento de comunicação. [...] privilegiado para o entendimento dos fenômenos de comunicação das classes subalternas [...] principalmente em regiões periféricas, tem sobrevivido ao impacto das mídias e dos processos predadores neoliberais. (FERREIRA, 2005, p.62).

Continuando com as idéias de Ferreira, as festas contribuem para que o homem procure a si mesmo e a sua identidade, bem como sua identidade "histórico cultural" num processo dialético entre o ser e o fazer. Prosseguindo com suas considerações, as festas das culturas subalternas "são categorias de cultura".

Portanto, as festas são acontecimentos ricos para pesquisas e compreensão das dinâmicas das comunidades, acontecimentos prazerosos de vivenciar. Estas qualidades e características próprias as tornam únicas como objetos de estudo do homem que vive na coletividade, assim como objetos de estudos fecundos do viver a experiência individual e coletiva dos homens das camadas subalternas. 


\subsection{Festa no Brasil}

No sábado seguinte a cidade revestira desusado aspecto. De toda parte correra uma chusma de povo que ia assistir à festa anual do Espírito Santo. Vão rareando os lugares em que de todo se não apagou o gosto dessas festas clássicas, resto de outras eras, que os escritores do século futuro hão de estudar com curiosidade, para pintar aos seus contemporâneos um Brasil que eles já não hão de conhecer. (MACHADO DE ASSIS). ${ }^{23}$

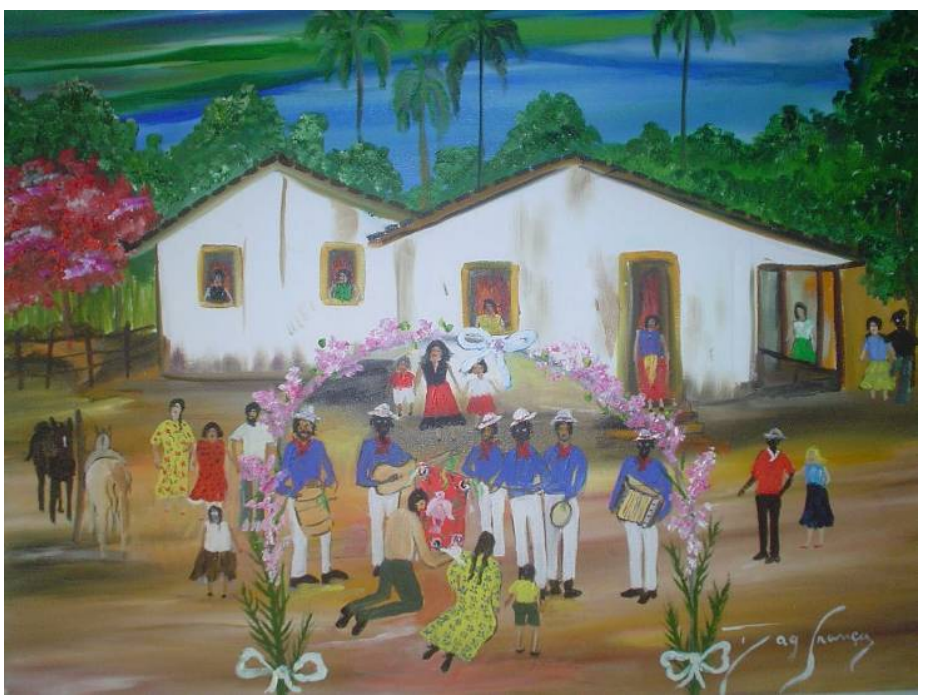

Imagem 3.3: Folia de Reis na Fazenda Rainha da $\mathrm{Paz}^{24}$

As festas estão presentes na constituição da brasilidade, atuaram como formas agregadoras da dicotomia entre poder e submissão, vida e morte, religioso e profano próprios do país. Entram como possibilidades de reintegração e redirecionamento do cotidiano e apontam para o exercício de uma identidade construída no mais significativo sentimento de interiorização de uma comunidade, a sua espiritualidade, motivo, na grande maioria das vezes, das realizações das festas no Brasil.

\footnotetext{
${ }^{23}$ Trecho do conto A parasita azul, de Machado de Assis (Capítulo IV - A Festa). Disponível em <http://www.dominiopublico.gov.br/download/texto/bv000186.pdf>. Este trecho abre a coleção Festa: cultura e sociabilidade na América Portuguesa, volume I, 2001, organizado por István Jancsó e Iris Kantor.

${ }^{24}$ Tela de autoria de Dag França. Disponível em: <www.alep.pr.gov.br/adm/arquivos/imagens/2623>. Acesso em: 23 de novembro de 2007.
} 
E, no campo dos estudos da cultura subalterna, a festa ganha um significado ainda maior. A festa popular está presente nas mais recônditas comunidades, rural ou urbana, bem como nos grandes centros, agregada às comunidades periféricas.

No Brasil, as atividades festivas também faziam parte das celebrações dos povos originários como marcos reguladores da dinâmica social. Com a chegada do europeu e a transplantação das culturas da África, as festas ganharam amplitude. Conservaram a essência e as formas ritualísticas de origem das diferentes culturas que aqui se estabeleceram, e foram agregando diferentes elementos no desenrolar da história brasileira.

A coabitação no mesmo espaço de diferentes culturas forçou a convivência e as festas ampliaram suas formas de atuação. Também incorporaram múltiplos elementos, fazendo surgir novos significados e simbolismos para atender às necessidades que se impunham no transcorrer de nossa formação cultural. Deste modo, transformaram-se na síntese do sentimento de brasilidade.

Nos primórdios da colonização brasileira, período que coincide com a implantação das idéias da Contra Reforma, a forte presença Jesuíta na Colônia fez com que cada núcleo habitacional fosse precedido da construção de uma capela e os primeiros núcleos educacionais controlados pelos religiosos. Esta característica é constatada a partir do momento que se observa a grande predominância de cidades e estabelecimentos que foram nomeados sob a evocação de um orago ${ }^{25}$.

\footnotetext{
${ }^{25}$ Santo a que uma capela ou templo é dedicado; Santo Padroeiro.
} 
Esta forte religiosidade transforma as capelas e as igrejas em centro irradiador de toda a vida da Colônia: era antes ou após as missas, rezas ou festas que notícias eram trocadas, planejamentos econômicos e políticos eram explicitados e a vida cotidiana era comentada e reavaliada. Esta característica se arrasta até os dias de hoje em muitas comunidades.

As festas religiosas do período da colonização traziam em sua constituição o teatro, a dança, os cortejos; vieram com os primeiros jesuítas e colonizadores, impregnaram o imaginário popular rural e urbano e adentraram os séculos como acontecimentos esperados e congregadores dos diferentes extratos da sociedade, atuando como catalisadora das dinâmicas intrincadas dos poderes dirigentes e subalternos da colônia, império e república, bem como da atualidade. Transformaram-se em acontecimentos esperados e reguladores das muitas comunidades onde aconteceram e acontecem.

Nelas, uma sociedade do espetáculo e para o espetáculo se formou, independentes de serem sagradas ou profanas - não se diz que o Brasil é o país do carnaval e que o ano brasileiro só começa na quarta feira de cinzas? Assim, o tempo foi e é marcado, e as relações sociais são reguladas em muitas comunidades do país, pelo antes e depois das festas. Nelas o passado é revivido, o presente equalizado, o futuro projetado.

As festas no Brasil, em sua maioria, tiveram sua origem nas atividades religiosas, desenvolvidas pelos jesuítas, e os primeiros relatos das atividades festivas são encontrados em seus escritos quando iniciaram a evangelização dos povos originários, conforme relata Tinhorão (2000), em seu livro As Festas no Brasil Colonial. Os jesuítas perceberam que, para atrair e cativar os povos originários, a música era uma boa estratégia, e foi através dela 
que foram introduzidas algumas atividades festivas religiosas dentro dos colégios, como a grande encenação para a comemoração do Martírio das Onze Mil Virgens, inaugurando uma forma religiosa de comemorar os santos e feriados religiosos.

A dramatização e a encenação já eram utilizadas e difundidas na Europa desde o medievo, reconhecidas como forma eficaz de evangelização; nas encenações da colônia, como na Europa, o profano se mescla com o sagrado, gerando as características marcantes das festividades denominadas folias.

As folias tiveram suas origens na península ibérica; eram danças acompanhadas de instrumentos musicais, principalmente castanholas e pandeiros, onde os homens se vestiam de mulheres e saíam às ruas numa dança selvagem. Gil Vicente, no Auto da Sibila Cassandra (1511), apresenta um personagem cantando folia, assim como outros autores fazem referência às folias como uma dança ligada aos ritos de fecundidade em sua origem, nelas, era comum o uso de máscaras. Eram essas folias e outras manifestações festivas, dramatizações e jogos que animavam as festas religiosas e laicas do reino e da colônia, das quais nem sempre o povo podia tomar parte.

Nas atividades oficiais, tanto do governo quanto da Igreja romanizada, o povo ficava apartado, destinado a permanecer como mero espectador. Mas, nas procissões, como a de Corpus Christi, Nossa Senhora do Rosário e a do Divino, era permitido ao povo participar. Nessas atividades, os autos, reminiscências da Igreja Medieval, eram encenados e as folias aceitas: era uma forma dos poderes oficiais utilizarem as dramatizações e encenações de fatos bíblicos, biografia dos santos e o giro das folias, como meio de 
evangelização, controle ideológico, moral e religioso. Com a presença do povo nos festejos, são incorporados ritmos, danças, sabenças e crendices profanas e o controle da Igreja e do Estado é esvaziado.

E o capelão da Lampadosa, percorrendo com vista a igreja pomposamente adereçada, dirigia-se à sacristia, tomava o Compromisso da Irmandade, lavrando os termos que deviam ser autenticados pelo Rei e pela Rainha na terminação do ato.

[...]

Esquisitos no trajar, no semblante, nos gestos, negras e negros novos irrompiam de dada lado, entregues à obediência de seus chefes, à vigilância nunca iludida da polícia, que os empreitava.

[...]

Da capelinha, de portas fechadas, o capelão à janela recreava-se do selvagem espetáculo, e os negros de nação, em pleno dia de Reis, julgavam-se venturosos de sua sorte, esquecendo-se dos desertos de sua terra e das travessias do mar. (MORAES FILHO, 1979, p. 226228). ${ }^{26}$

Com a consolidação da colônia esse esvaziamento é ampliado,

pois o número de membros da lgreja oficial não é suficiente para atender a demanda e a Igreja romanizada passa a delegar para leigos e membros das inúmeras confrarias religiosas que surgem neste período, a organização e assistência religiosa à grande massa de mestiços, negros e membros das nações originárias. Desta forma, as festas também passam para o controle dos leigos.

No Brasil, nos domingos e feriados, principalmente, dos santos, a grande massa de escravos se reunia para dançar e festejar. Tinhorão (2000, p.41) faz uma citação que descreve a população do Brasil em 1584 como sendo "a massa dos portugueses, representantes dos $16 \%$ de brancos da população de 60.000 habitantes da colônia (em que $50 \%$ ou 30.000 eram índios 'mansos' e 34\% ou 20.000 africanos)". Deste modo, no início da formação do país, as festividades estavam vinculadas a três possibilidades: a

\footnotetext{
${ }^{26}$ Trecho do texto "Coroação de um Rei negro em 1748", de Mello Moraes Filho, retirado do livro Festas e Tradições Populares do Brasil. No transcorrer deste trabalho serão feitas várias referências a este texto.
} 
religiosa, promovida pelos jesuítas; a laica, promovida pela e para a elite portuguesa e a que o povo - negros e originários da terra - realizava à margem da sociedade hegemônica.

Quando os finórios [escravos] terminavam sua duríssima semana de trabalho, recebem permissão para do mesmo modo aproveitar a seu gosto os domingos, quando, reunindo-se em locais determinados, incansavelmente dançam de manhã à noite com os mais variados saltos e contorções do corpo, ao som de tambores e pífanos tocados com muita propriedade, homens e mulheres, jovens e velhos, no meio da maior confusão, enquanto outros andam em voltas tomando uma forte bebida feita de açúcar chamada de grape [grapa, garapa]; assim também gastam certos dias santos, nessa dança sem fim em que acabam tão empoeirados e emporcalhados a ponto de se tornarem às vezes irreconhecíveis. (TINHORÃO, 2000, p.57).

Essa dinâmica de ter nos espaços festivos, atividades profanas

e de cunho religioso propicia o surgimento de um catolicismo oficial e outro catolicismo estruturado pelo povo. Roger Bastide (1960) define essa dualidade como "catolicismo oficial" e "catolicismo popular".

Também a parceria entre o Estado Português, mandatário na Colônia, e a catequização religiosa própria do período fizeram surgir um calendário de comemorações oficiais vinculadas a festividades religiosas, em que grandes atividades, como procissões e festas, já nasceram incorporadas ao cotidiano da sociedade que se formava, como podemos constatar:

As Ordenações do Reino fixavam em quatro o número de procissões anuais, às quais era obrigatório comparecer: a São Sebastião (janeiro), Corpus-Christi (maio ou junho), a Visitação (julho) e a do Anjo da Guarda (julho). Em 1757, uma procissão foi acrescentada: a de São Francisco de Borgia, protetor do Reino. Era incumbência da municipalidade o controle da participação nas procissões, sobretudo das autoridades locais. A presença das confrarias e das irmandades, com seus emblemas e bandeiras, era obrigatória. (PEREZ, 2000, p.11).

O espírito festivo da colônia foi forjado sob a proteção do

Estado e da Igreja e todo acontecimento religioso era transformado em festa e 
sua preparação e realização mobilizavam a população rural e urbana em vários dias de organização. O dia da festa era o dia de encontro de todas as camadas que constituíam a colônia, senhores se deslocavam de seus engenhos e propriedades rurais com suas famílias e séqüitos de escravos e subordinados. Os núcleos urbanos eram transformados numa efervescência de diferentes atividades: casamentos, batizados, negócios realizados, bem como se pulverizavam as estratificações sociais e raciais.

Nos dias de festas oficiais, outras festas paralelas ocorriam, eram nesses encontros que os negros batucavam longe dos casarios e os senhores fortaleciam suas confrarias religiosas exibindo-se em cortejos de fausto e pompa.

Neste burburinho em que se transformavam os núcleos urbanos, a música, a dança, a comida, a reza de diferentes procedências e culturas e vários códigos foram se fundindo, o caldeamento de uma nova cultura se delineando e uma sociedade do espetáculo e para o espetáculo se formando: nosso caráter festivo.

As novenas, a procissão e a festa propriamente dita constituíam os momentos centrais. A igreja e as tribunas erigidas na praça, ornadas de bandeirolas, as feiras, a música das bandas, os fogos de artifício, os sinos tocando sem parar, em resumo, um espetáculo extraordinário, grandioso, a que as pessoas assistiam maravilhadas. (PEREZ, 2000, p.11).

Toda essa efervescência era realizada sobre os olhos atentos e controladores da Igreja e do Estado, mesmo quando surgiram confrarias religiosas vinculadas aos negros e à grande massa de mestiços, que nelas explicitavam suas crenças e modo de ser; não obstante, as confrarias serviram muitas vezes para que a elite hegemônica controlasse o povo. 
Das atividades religiosas do interior das confrarias dos senhores e do povo o desdobramento festivo alcançava as atividades laicas como os bailes e os banquetes e uma nova ordem social nascia. Toda atividade festiva e religiosa era organizada por um festeiro ou membro dirigente das confrarias que adquiriam o status de condutores espirituais e sociais, exercendo uma liderança paralela aos poderes oficiais.

As festas da colônia vão ganhando força e se agregando ao imaginário da grande massa. Porém, é no período barroco que elas ganham destaque como ethos da cultura em formação.

O barroco, antes de tudo, é visto por muitos teóricos, como a arte da comunicação para as massas por excelência e, conseqüentemente, a visão de mundo do período no qual esteve inserido é gravada em suas manifestações artísticas. No Brasil, no ciclo do ouro, o barroco se estabelece. Nesse período histórico foi assentada a base do que se considera brasilidade para muitos estudiosos. Assim, para falar das festas brasileiras, é necessário falar das festas barrocas.

\begin{abstract}
A festa à brasileira, carnal e orgiástica, é uma das melhores evidências do caráter híbrido de nossa sociedade e de sua maneira de operar através do entrecruzamento de códigos e de registros. A festa, coisa pública e domínio da rua, favorece a mestiçagem à medida que provoca uma quebra no encadeamento dos determinismos. O povo na rua, a rua em festa: folia, orgia, fantasia, sedução, violência, transgressões de toda ordem combinam-se a um clima geral de afetividade, de familiaridade, de encontro, compondo uma maneira singular de estar coletivamente que age pela via da carnavalização ou, dizendo de modo ainda mais claro, da barroquização. (PEREZ, 2003).
\end{abstract}

$\mathrm{Na}$ literatura brasileira recente sobre esse tema, quase todas são unânimes em apontar as festas do período barroco como matriz geradora das manifestações festivas encontradas nos dias atuais. Nelas são descritas festas que ganharam dimensão de fatos históricos como: 
[...] o Triunfo Eucharistico, de Simão Ferreira Machado, datado de 1734, narrando as festividades que no ano anterior assinalaram a inauguração da nova matriz de N. S. do Pilar, mandada construir em Vila Rica pelos moradores do bairro de Ouro Preto, e a solene trasladação para esse templo da Eucaristia, provisoriamente depositada na igreja de N. S. do Rosário dos Pretos. Ou, ainda, a celebração de cunho ao mesmo tempo religioso e profano que assinalou, em 1748, a posse de Dom Frei Manoel da Cruz, bispo cuja investidura marca a instalação da diocese em Mariana: obra de autor anônimo, a narrativa foi editada em Lisboa no ano seguinte pelo cônego Francisco Ribeiro da Silva, do cabido da nova sé, seguido o relato de uma coletânea de peças literárias alusivas ao acontecimento e dando-se ao todo o título de Áureo Trono Episcopal (Kantor, 1996). No mesmo veio se poderia analisar a Relação das faustíssimas festas que celebrou a Câmara da Vila de Nossa Senhora da Purificação e Santo Amaro da Comarca da Bahia pelos augustíssimos desponsórios da Sereníssima Senhora D. Maria, Princesa do Brasil com o Sereníssimo Senhor D. Pedro, Infante de Portugal, em 1762 (Calmon, [1762] 1982); dos 'obsequiosos festejos' da cidade de São Sebastião do Rio de Janeiro pela notícia do nascimento do 'sereníssimo senhor príncipe da Beira, o Senhor D. José,' em 1763; bem como todo o conjunto de outras 'relações' de 'festas públicas' que, em 1770, fez celebrar o governador e capitão general na cidade de São Paulo em louvor a Sant'Ana, por ocasião de se colocar sua imagem no altar novo da Igreja do Colégio; ou das numerosas outras e mais antigas 'entradas' de excelentíssimos e reverendíssimos senhores bispos e arcebispos, quer se trate de ilustre dignatário e fiel servidor de Deus no Rio de Janeiro (a exemplo do que ocorre em 1747), quer, antes dele, do Arcebispo Primaz de todas as Espanhas, em junho de 1741. (MONTES, 1998).

\section{A festa barroca é vista ainda pela historiografia como}

estruturante da tessitura de interpenetração de culturas e dicotomias, podendo

ser estudada como um fato social. Nela a ordem social vigente é explicitada: o

local do domínio, do oficial, da hegemonia, assim como o local do povo, da subalternidade. Nas descrições das festas barrocas, os elementos iconográficos são detalhadamente evidenciados, fornecendo, para o pesquisador atual, um fértil campo para o cruzamento das informações obtidas nas festas realizadas na contemporaneidade, propiciando a análise do deslocamento de seus elementos fundantes, como descrevem Massimi e Guedes (2004, p.77):

[...] a festa do Triunfo Eucarístico, resultado do empenho da população na construção da Igreja - , mostrou em detalhes a abundância de ouro e diamantes nas vestimentas e enfeites dos mineiros. 
O Acontecimento havia sido anunciado por um bando de mascarados, e, no dia da festa, as janelas das casas amanheceram enfeitadas com sedas e damascos. Após a missa, deu-se inicio a procissão, constituída por uma dança de turcos e cristãos com dois carros, dentro dos quais iam músicos de suaves vozes e vários instrumentos, uma dança de romeiros, uma dança de músicos, os quatro cavalheiros dos ventos (norte, sul, leste e oeste), um cavalheiro alemão tocando clarim, dois negros galantemente vestidos, dois pajens com roupas de ouro e diamantes encravados, que davam "Vivas a Ouro Preto", duas figuras significando os morros de Ouro Preto e Ouro Fino, as sete figuras representando os planetas, esses últimos precedidos pela Lua $e$ as figuras representando as estrelas d'Alva e da Tarde, alem do sol. As várias irmandades, com suas cruzes e seus andores, eram precedidas por um gaiteiro. Por fim, seguia um numeroso séqüito de nobres e moradores da vila com o andor, o numeroso clero das duas paróquias da vila e o Eucarístico Sacramento nas mãos do vigário da Matriz. A festa prosseguiu com nova missa e, nos dias seguintes, ocorreram cavalhadas, espetáculos de fogos de artifícios, comédias, três dias de touros, serenatas e banquetes para os nobres.

Toda festa explicita uma ordem social, mesmo nas mais humildes e distantes comunidades. Nela, a hierarquização é possível de ser estudada e, conseqüentemente, permite compreender as possibilidades de estruturação das comunidades que as realizam, bem como compreender os elementos iconográficos que the permitem sobreviver às constantes interferências sofridas no transcorrer histórico e suas possíveis adaptações. Como exemplo, podemos citar o uso das bandeiras, mastros, máscaras e fantasias, presentes em quase todas as festas da atualidade. Esses elementos remontam as manifestações do medievo europeu que se fixaram na tradição brasileira através das festas barrocas.

Os elementos iconográficos encontrados nas festas barrocas do período colonial brasileiro transcenderam os séculos e continentes e podem ser estudados como materialização e visão holística do viver do homem daquele período e de hoje. Desta forma, a cultura brasileira possui um "ethos barroco" presente na atualidade e perfeitamente visível nas festas mais populares como o carnaval, as procissões de Semana Santa, os desenhos dos tapetes das 
procissões de Corpus Christi, as cavalhadas e cururus, o carnaval de Olinda, para citar somente algumas manifestações estéticas e festivas de nossa barroquização contemporânea.

Nas fotos abaixo observa-se a transferência dos elementos estéticos encontrados numa pintura barroca para outros da atualidade, como os percebidos na bandeira do Divino.

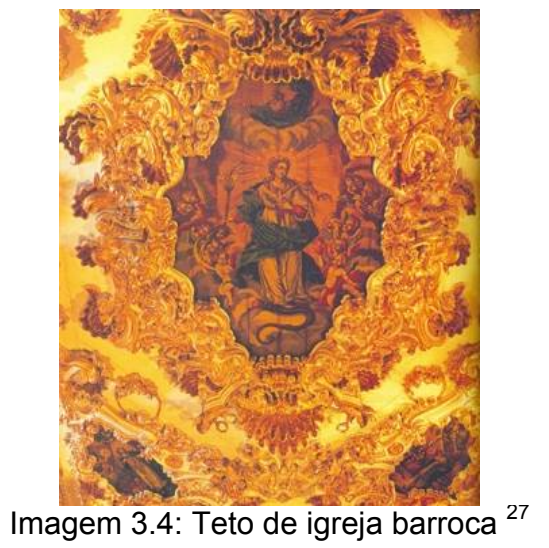

Imagem 3.4: Teto de igreja barroca ${ }^{2 \prime}$

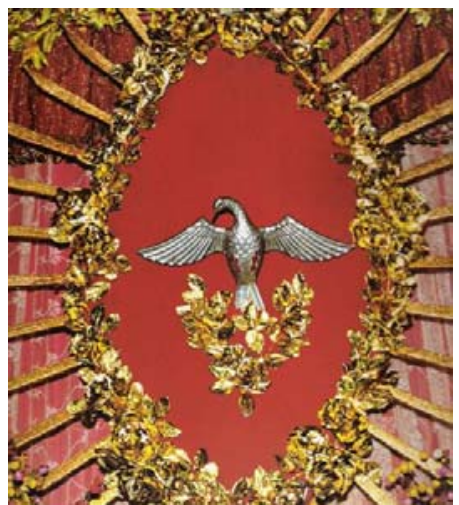

Imagem 3.5: Detalhe de Bandeira do Divino ${ }^{28}$

Segundo Perez, o barroco e seu desdobramento nas festas explicitam uma atitude estética, ética e filosófica, não em sua dimensão estritamente artística, mas de estilo de vida, de atitudes vivenciadas no cotidiano. Perez (2003) cita, ainda, as considerações de Bastide (1978, apud PEREZ, 2003, p.35), nas quais destaca as características que aqui desenvolveu o barroco:

[...] se destaca dos muros das igrejas, das fachadas dos palácios, desce as majestosas escadas para se espalhar nas praças, em suas grandes avenidas que terminam em horizontes de azul, para tomar posse do corpo humano, complicando-o com suas perucas e fitas; ele invade a rua com suas procissões, carros alegóricos, sua pompa de um momento, atingindo as almas através do ritual de polidez e do subjetivismo de seus sentimentos.

\footnotetext{
27 Teto da nave central da Igreja de Nossa Senhora da Conceição dos Militares, Recife, Pernambuco in Universo Mágico do Barroco Brasileiro, Emanoel Araújo (curador) - São Paulo: SESI, 1998, p. 198.

${ }^{28}$ Bandeira do Divino, São Luis do Paraitinga, São Paulo. In Festas de Fé: Brasil, de Percival Tirapeli e fotografias de Rosa Gauditano. São Paulo: Meta Livros, 2003, p. 74.
} 


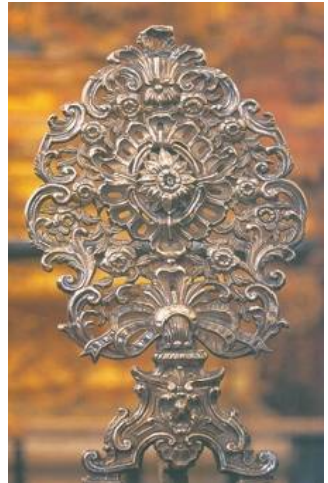

Imagem 3.6: Palma ${ }^{29}$

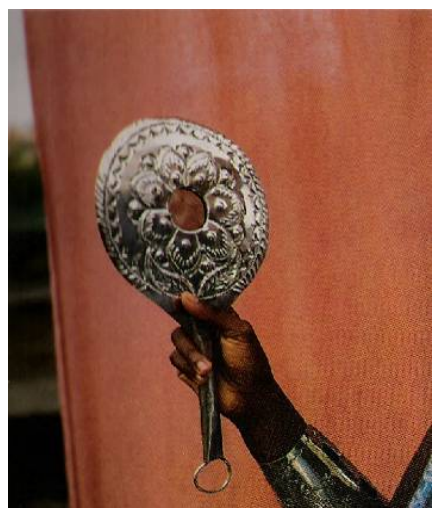

Imagem 3.7: Objeto que compõe a figura de lemanjá ${ }^{30}$

O que é notável no Brasil é o quanto, para além das periodizações canônicas da História da Arte, o barroco se desdobra nesses resíduos seiscentistas que, como assinala com razão Affonso Ávila (1967), se espraiam como fenômeno de civilização, nos centros urbanos que, por irradiação do fausto das Minas, irão se expandir mesmo em zonas mais afastadas, no interior da província assim como ao longo do extenso litoral do país. É um fenômeno de civilização porque constrói ao mesmo tempo uma mentalidade e um estilo de vida, híbridos na colônia como híbrida é sua formação. $E$, na sociedade de espírito aristocratizante, a mão mestiça, mameluca, mulata, afro-brasileira, mão de trabalho e de criação, deixará, indelével, sua marca nas formas barrocas de nossa arte. (MONTES, 1998).

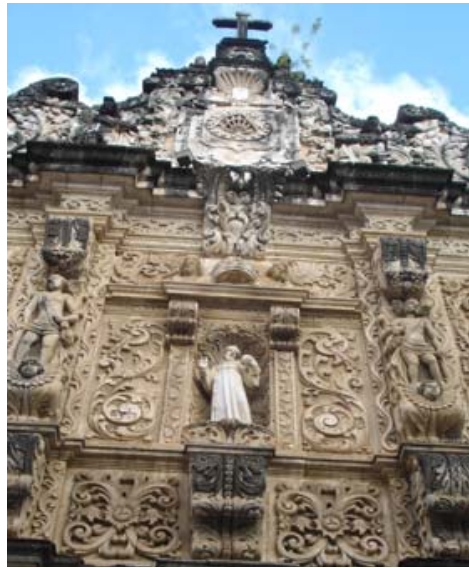

Foto 3.1: Detalhe da fachada da Igreja da Ordem Terceira de São Francisco, Salvador/BA ${ }^{31}$

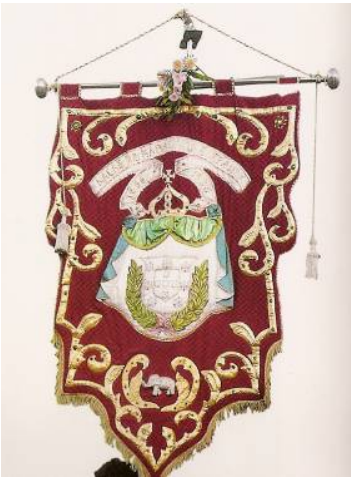

Imagem 3.8: Porta Estandarte de Maracatu

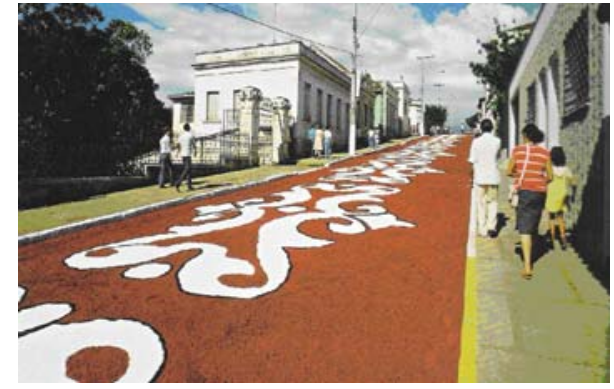

Imagem 3.9: Tapete da procissão de Corpus Christi ${ }^{33}$

${ }^{29}$ Palma de altar, séc. XVIII, prata, $65 \times 35 \times 18 \mathrm{~cm}$, Mosteiro de São Bento de Olinda, PE. In Universo Mágico do Barroco Brasileiro, Emanoel Araújo (curador) - São Paulo: SESI, 1998, p. 299.

30 In Danças Populares Brasileiras, coordenação Ricardo Ohtake, fotos de Rômulo Fialdini. Projeto Cultural Rhodia, 1989, p. 157

${ }^{31}$ Fachada em pedra lavada da Igreja da Ordem Terceira de São Francisco, Salvador/BA. Foto da autora, 2007.

32 In Danças Populares Brasileiras, coordenação Ricardo Ohtake, fotos de Rômulo Fialdini. Projeto Cultural Rhodia, 1989, p. 34.

${ }^{33}$ Tapete da procissão de Corpus Christi, São Manoel/SP, 1986. In Festas de Fé: Brasil, de Percival Tirapeli e fotografias de Rosa Gauditano. São Paulo: Meta Livros, 2003, p. 71. 
Mesmo após a chegada da Missão Artística Francesa no primeiro reinado, que oficializou uma arte tipicamente hegemônica - o neoclassicismo - e com os esforços em propagar a modernidade introduzida na virada do século XIX para o século XX para refazer nosso ethos estético, 0 povo continuou barroco e foi, exatamente, na implantação e consolidação do modernismo brasileiro e na atualidade que nossas heranças culturais barroquizadas foram e são valorizadas como elementos "antropofágicos" de nós mesmos. Não mais comemos o Bispo Sardinha, comemos a nós mesmos.

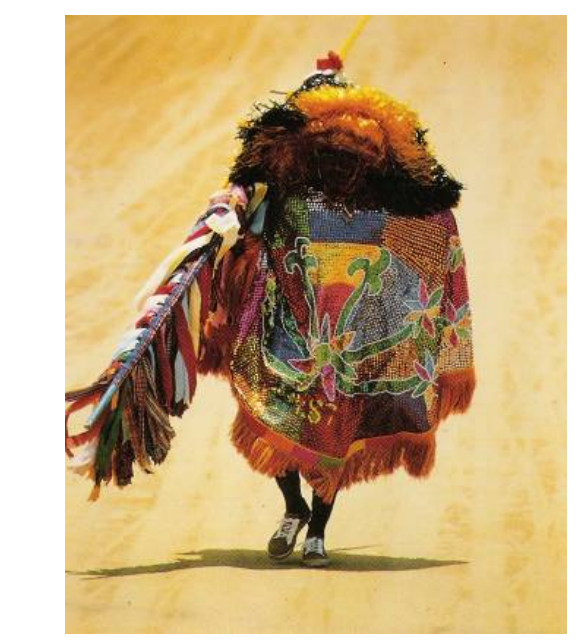

Imagem 3.10: Caboclo de lança de Maracatu Rural $^{34}$

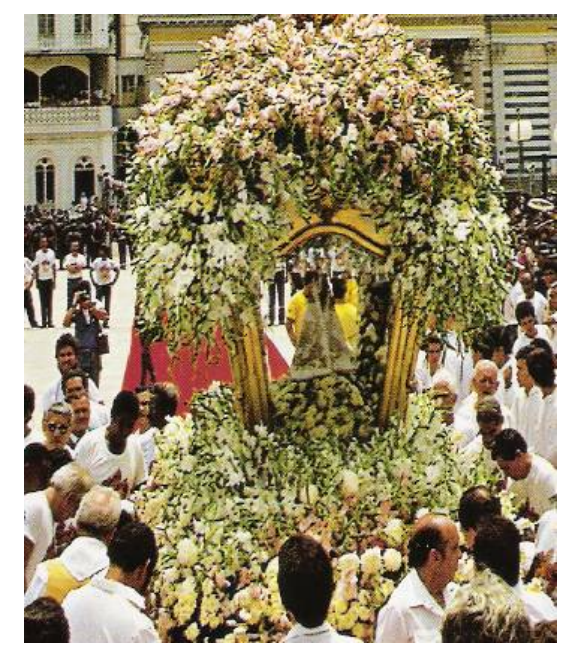

Imagem 3.11: Procissão de Círio de Nazaré, Belém/PA, $1986^{35}$

As imagens acima atestam o gosto pelo excesso de elementos e detalhes, tão característicos na maioria das festas populares.

$\mathrm{Na}$ atualidade, esse barroquismo passa a ser visto como forma de marcar a identidade no mundo globalizado, não só de caráter estético, mas principalmente como modo de viver e se relacionar com as dicotomias sociais implantadas a partir da independência, da virada modernizadora das primeiras décadas do século XX, e hoje, no neoliberalismo.

\footnotetext{
${ }^{34}$ In Danças Populares Brasileiras, coordenação Ricardo Ohtake, fotos de Rômulo Fialdini. Projeto Cultural Rhodia, 1989, p. 41.

${ }^{35}$ In Universo Mágico do Barroco Brasileiro, Emanoel Araújo (curador) - São Paulo: SESI, 1998, p. 134.
} 
O caráter festivo e festeiro do brasileiro é motivo de análises antropológicas e sociológicas na atualidade. É possível ver, no carnaval, por exemplo, a expressão máxima dessa idéia de "festa brasileira". Nele as estratificações sociais são explicitadas e desestruturadas, uma outra ordem imaginária é implantada, própria do espírito que se desenvolveu e que podemos chamar de brasileiro.

Hoje, é possível reconhecer como estética brasileira nativa a "estética barroca" dos altares, das procissões, dos andores, dos bordados, da decoração das festas populares. A festa brasileira é, portanto, portadora de uma estética de imagens multiformes e de diferentes fazeres artísticos oriundos das comunidades que a produzem, um objeto heurístico das múltiplas formas de experienciar nosso viver.

A atitude barroca 'procura transformar em festa o mundo visível, isto é, coloca a atividade produtiva a serviço do divertimento' através de uma 'dramatização fantástica' que 'sugere uma festa fantástica e perpetuamente inacabada' (DUVIGNAUD, 1984: 130, 138). Ora, é exatamente isso a carnavalização da vida no Brasil, onde tudo começa e tudo termina por um carnaval/festa, o que equivale a dizer que nada começa efetivamente, do mesmo modo, que nada termina definitivamente. Vivemos sempre em movimento, no trânsito, na abundância, no excesso carnavalesco. (PEREZ, 2003).



Imagem 3.12: Nossa Senhora do Carmo e detalhe do manto ${ }^{36}$

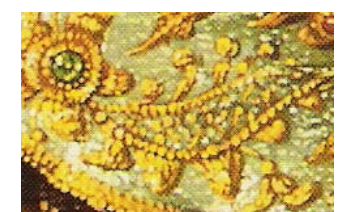

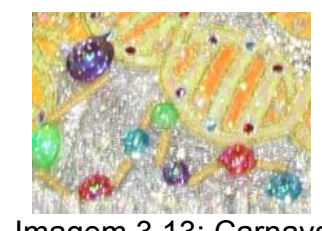

Imagem 3.13: Carnaval Porta-Bandeira e detalhe da saia ${ }^{37}$

\footnotetext{
${ }^{36}$ Nossa Senhora do Carmo, Raimundo da Costa e Silva (ativo no Rio de Janeiro no séc. XVIII e XIX). Rio de Janeiro, séc. XVIII. Óleo sobre tela. $81 \times 61,5 \mathrm{~cm}$. Museu Nacional de Belas Artes, RJ. In Universo Mágico do Barroco Brasileiro, Emanoel Araújo (curador) - São Paulo: SESI, 1998, p.242.
} 
O caráter festeiro da formação dos brasileiros é tão evidente

que, mesmo as comemorações cívicas, como os desfiles de 7 de setembro, ganham dimensão festiva. $\mathrm{Na}$ atualidade, os meios midiáticos também se apropriam desse ethos festivo, bem como os programas oficiais e privados para incentivar o turismo, se encarregaram de propagar essa índole das festividades presentes em nossos modos de ser e viver. Até mesmo no luto, esse caráter festivo se faz presente, como nas rodas de "compadres" regadas a "café" e "pinga", que viram a noite acompanhando a despedida do ente querido em velórios, animados por lembranças vividas que muitas vezes parecem mais um encontro festivo. É preciso lembrar que a morte também ganha caráter festivo nos dias de Finados, em que a comida, o comércio, as flores e o encontro com conhecidos, transformam-se numa grande celebração.

Qual o significado dessas formas de cultura características do mundo popular que parecem indicar que, qualquer que seja o motivo ou pretexto, no Brasil tudo tende a acabar em festa? Uma primeira e evidente questão naturalmente se coloca frente a esse universo: confrontados com a multiplicidade e heterogeneidade dessas manifestações, como falar ainda, no singular, de festa e cultura popular?

Frente a tal diversidade, 0 bom senso e o rigor científico recomendariam antes que se renunciasse a falar do popular e da festa no singular, para apreender em sua infinita diversidade as festas do povo, já que, não obstante todas as suas diferenças, o que essas distintas manifestações têm de comum, apesar de tudo, é o fato de serem predominantemente produzidas e consumidas pela gente simples deste país, das cidades e do campo, permitindo-nos englobá-las nessa designação descritiva genérica, mas suficientemente explorada para que se possa falar, grosso modo, de universo das classes populares, onde se poderia afirmar que uma cultura da festa aparece como marca característica neste país, do Oiapoque ao Chuí. (MONTES, 1998, p.3).

\footnotetext{
37 Imagem de internet. Disponível em: <http://lh4.ggpht.com/_ql8Q2pM4dSc/RgXDDa5F1fl/AAAAAAAAANY/87NxA1tZ33s/V.+l.+25-0207.+541.jpg>. Acesso em: 26 de outubro de 2008.
} 


\subsection{Folia de Reis}

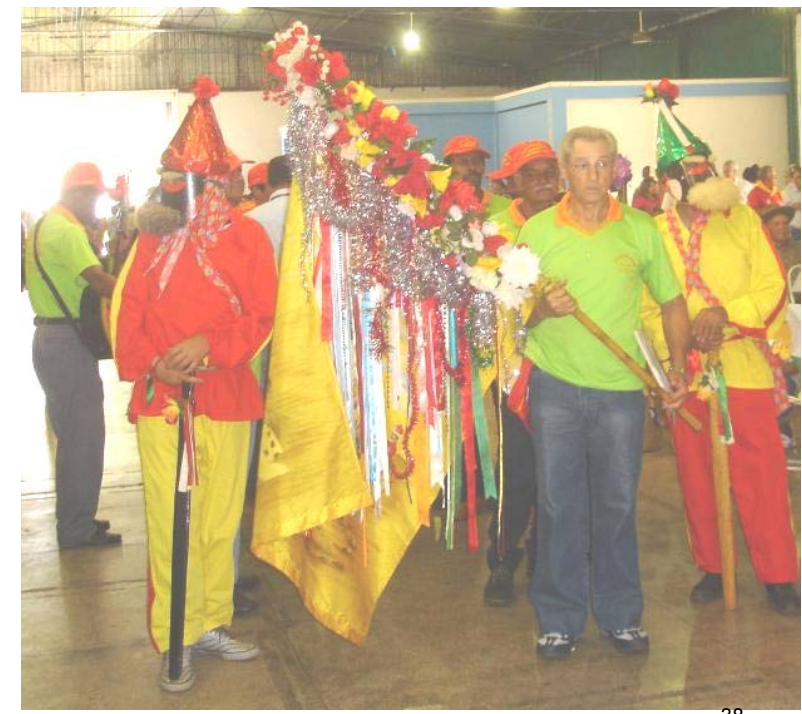

Foto 3.2: Encontro de Folia de Reis, Assis/SP ${ }^{38}$
A vinte e cinco de dezembro

Se reúnem os foliões

E vão prá rua

Bater caixa nos portões

Lá vão pandeiro, sanfoneiro, violões

Santos Reis aqui chegou ai, ai

Pra visitar sua morada ai, ai, ai, ai)

Eles só voltam prá casa dias seis

Dia de Reis

Por sete anos se repete o ritual

Pra todo canto levam o bem,

espantam o mal

Ô de casa, ô de fora

Quem de dentro deve estar

Os de fora Santos Reis

Que lhes vieram visitar

Que vieram visitar, ai, ai

$\mathrm{Na}$ folia tem palhaço

Que faz verso e diabrura

Representa o tinhoso

Tentador das criaturas

Mas também tem a bandeira

A Bandeira do Divino

Mais atrás os três Reis Magos

Procurando o Deus Menino

Ô de casa, ô de fora...

Batem lá na sua porta

Pra pagar uma promessa

Levam mestre e contra-mestre

Pra poder cantar a beça

Dia vinte de janeiro

Eles dão uma festinha

Com viola, violeiro

Desafio e ladainha

Ô de casa, ô de fora...

As festas religiosas, como objeto de estudo, propiciam um vasto

campo de investigação. Nelas transpõe-se o tempo presente para vivências de

outras dimensões da memória e da história. Nesta perspectiva, ao estudar uma

festa é possível transitar em diferentes Ciências e elaborar estudos

interdisciplinares.

${ }^{38}$ Foto da autora, realizada no Encontro de Folias da cidade de Assis/SP, em janeiro de 2008.

39 Letra de música disponível em: <http://martinho_da_vila.hipermusicas.com/folia_de_reis/>. Acesso em: 20 de setembro de 2007. 
Por instantes, o tempo dos relógios é suspenso, o homem experimenta o tempo mítico da eternidade e da manifestação divina que permite a reconciliação de todos com todos. Nesse sentido, as festas revelam a essência fundante de respeito à fé e à fraternidade comunal, que alimentam as manifestações religiosas e perpetuam as tradições que constituem um verdadeiro patrimônio cultural. (JURKEVICS, 2005, p.74).

A escolha das Folias de Reis como objeto de estudo deste trabalho foi o resultado da observação das festas populares na região e cidade de Ourinhos, da convivência amistosa com seus festeiros, da proximidade e vizinhança com os protagonistas. Um conhecimento empírico que foi transformado no transcorrer dos estudos, pois

Segundo Clifford Geertz, 'O lócus de estudo não é o objeto de estudo. Os antropólogos não estudam as aldeias (tribos, cidades, vizinhanças...), eles estudam nas aldeias' (GEERTZ, 1989, p. 32). [...] $\mathrm{Na}$ verdade, por se tratar de uma realidade com o qual convivemos, onde se encontram nossas raízes culturais, é que lançamos o olhar sobre a aldeia, como ponto de partida para ampliar o olhar analítico sobre a cultura universal. (SILVA, 2005, p.452).

Após levantamentos, foi constatado que nas Folias de Reis é possível encontrar elementos suficientes para discutir a permanência nas festas promovidas pelas culturas subalternas de elementos portadores das raízes da brasilidade e, portanto, representantes da cultura do país; bem como reconhecer que esses elementos são geradores de um vasto processo comunicativo, que garante às culturas populares a continuidade de suas bases culturais.

Fez-se necessário então, a partir deste levantamento, compreender as Folias nos seus múltiplos aspectos, principalmente quanto ao seu caráter de conservação e difusão da memória histórica e das culturas locais. 
Por isso, foi importante e necessário encontrar as origens das Folias de Reis para subsidiar a compreensão de seus elementos fundantes e como estes transpuseram o tempo e o espaço e se reconfiguraram na atualidade.

As folias encontradas na região podem ser divididas em festas vinculadas ao ciclo natalino e as que se realizam fora deste período, como a folia do bairro de Ribeirão Grande - Ourinhos, que acontece concomitante aos festejos juninos. Far-se-á uma análise da evolução dos principais elementos que as constituem para subsidiar e sustentar outras considerações que serão desenvolvidas.

\subsubsection{A origem das Folias de Reis}

A crença na vinda de um portador de boas novas messianismo - está vinculada a muitas culturas e mitos. Na cultura ibérica, manifesta-se, principalmente, no ciclo Natalino e nas comemorações epifaníacas; entretanto, através dos estudos de Ferreira (2000) pode-se vincular a origem desta fé bem antes da difusão do Cristianismo, nos cultos e festas pagãs.

Ainda segundo Ferreira, as festas de caráter religioso na antiga Roma estão vinculadas aos rituais agrários e aos dos solstícios. Próximo do solstício de inverno, eram celebradas as chamadas Saturnálias: celebrações em homenagem ao Deus Saturno. Este Deus estava associado ao "conhecimento das artes e particularmente da agricultura e do uso da moeda", bem como: 
[...] era o portador da ciência sagrada. Após os ensinamentos de Saturno, os homens conquistaram a áurea aestas, isto é, a Idade do Ouro, passando a viver em pace e tranquilla operosità, senzaguerre e conflitte sociali, pois não havia diferenças entre classes sociais. (FERREIRA, 2000, p.123).

A autora relata que na narrativa do mito de Saturno, o deus permanece com os homens por um período e depois desaparece. Com esse desaparecimento, também desapareceu a "Idade do Ouro", por isso, as festividades que comemoravam Saturno estão vinculadas às crenças de seu retorno, juntamente com o tempo de prosperidade e paz atrelada ao deus. Seu culto era muito difundido entre os romanos, sua invocação e comemorações festivas aconteciam entre o que são hoje os dias 17 até 23 de dezembro. Compreendia as festividades das saturnálias uma parte sagrada que acontecia no interior dos templos e outra profana, onde um banquete coletivo era realizado. Trocavam-se presentes, e programavam-se atividades lúdicas com danças e jogos de azar; também as atividades proibidas eram liberadas juntamente com a subversão da ordem social.

Outra comemoração vinculada aos romanos que ecoa nas tradições dos ibéricos foram as festividades ao deus Jano: seu nome é associado ao mês de janeiro, Deus com duas faces, uma voltada para o passado, a outra para o futuro. Com o passar do tempo essas festividades foram incorporadas e vinculadas ao solstício de inverno e aos cultos à fertilidade da terra, principalmente as relacionadas à cultura Celta.

A crença e difusão dessas festas e comemorações impregnaram-se na cultura romana e adjacências e, mesmo após a expansão do cristianismo, os povos catequizados mantiveram seus festejos vinculados às crenças locais e profanas em seu calendário, independente das fortes censuras 
e proibições da nova lgreja. Para ampliar esse controle e proibições, algumas comemorações da liturgia cristã e suas festas foram deslocadas para o período que antecede a quaresma, vinculando-as ao que hoje é denominado de ciclo natalino, ou epifania.

Ainda, é necessário salientar que, no início do cristianismo, não havia data específica para as comemorações dos relatos bíblicos como o nascimento de Cristo, a visita dos três Reis Magos ao filho de Deus; elas aconteciam em diferentes momentos. Foi o Papa Julio I, em 367 d.C. quem unificou o calendário cristão e fixou a data de 25 de dezembro para a festa do nascimento de Cristo e dia 6 de janeiro para celebração e adoração dos Reis Magos. Essas datas estão muito próximas das comemorações vinculadas aos cultos pagãos que permaneceram na Europa, reminiscências das festas de solstícios, das comemorações januais e das saturnálias e, independente do controle, a Igreja cristã incorporou em seu calendário festas que remetiam ao passado e tradições dos povos europeus e asiáticos.

Desse modo, durante a estruturação, consolidação e interpretação da doutrina cristã, de forma mais acentuada no medievo, muitas crenças pagãs e a visão mística do povo se entrelaçaram, se incorporaram e adentraram os textos bíblicos, fazendo surgir uma prática conhecida como catolicismo profano, que confrontou o catolicismo romanizado atrelado aos dogmas de Roma. Nasce, desta forma, um "hibridismo"40 religioso que permanece até a atualidade.

\footnotetext{
40 O termo Hibridismo neste texto é usado a partir dos pressupostos emitidos por Garcia Canclini [...] "entendo por hibridação processos socioculturais nos quais estruturas ou práticas discretas, que existiam de forma separada, se combinam para gerar novas estruturas, objetos e práticas. Cabe esclarecer que as estruturas chamadas discretas foram resultado de hibridações, razão pela qual não podem ser consideradas fontes puras."
} 
Essas conjunturas apontam para a origem das muitas crenças e práticas encontradas nas festas natalinas ou janeiras, como a troca de presentes, as ceias e almoços próprios deste período, assim como o costume de pedir "Ano Bom" em muitas localidades no dia primeiro do ano. Nas Folias de Reis, a tradição de pedir aos Santos Reis proteção para as colheitas e prosperidade, e a de se preparar e iniciar as festividades do reisado a partir do dia 25 de Dezembro e encerrá-las até o dia 6 de Janeiro remontam a essas festividades do passado pagão ${ }^{41}$ europeu.

A Igreja, desde seus primórdios, principalmente a Igreja Medieval, utilizou o teatro e a encenação dos episódios bíblicos como forma de catequização. Portanto, os autos da natividade com a presença dos reis magos já figuravam nessa prática. Originariamente apresentados em latim, paulatinamente passaram a ser apresentados nas línguas nativas, como forma de intensificar a catequização. Do mesmo modo, deixaram de ser representadas somente as narrativas com os personagens da natividade e ampliaram a dramaturgia com a presença dos pastores, da estrela, o anúncio aos Reis pelo anjo, a viagem de ida e volta dos Reis, a fuga de Herodes, a oferta dos presentes. Enfim, o texto bíblico podia ser representado completo, desde as profecias do Antigo Testamento, até os relatos da natividade do Novo Testamento, como: Isaías IX, 6 e 7; Isaías XI 1-10; Miquéias V, 1-5 (Antigo Testamento) e Lucas I, 26-38; Lucas I, 39-45; Lucas II, 1-20 e Mateus II, 1-12

Também presente na considerações de Peter Burke "[...] o termo 'hibridismo' aparece com freqüência em estudos pós-coloniais, na obra de Edward Said, por exemplo. "[...] todas as culturas estão envolvidas entre si" escreve Said a respeito de nossa situação atual, "nenhuma delas é única e pura, todas são híbridas, heterogêneas". Embora ele trate o termo com mais ambivalência, ou melhor, enfatiza sua ambivalência, a idéia de hibridismo também é central na obra de Homi Bhabha". BURKE, Peter. Hibridismo Cultural. RS: Unisinos, 2003.

41 O termo pagão, ou festas pagãs, é atribuído, na antiguidade, ao sentimento religioso de se oferecer dádivas aos deuses como súplica para se obter ou agradecer suas benesses. Ainda, ato de purificar um local sagrado (expiação). Após a introdução do cristianismo, pagãos eram considerados todos aqueles que tinham práticas religiosas não vinculadas ao catolicismo romano ou os não batizados. 
(Novo Testamento). Nos textos bíblicos, os Reis podem ser encontrados como sendo Magos, como aparece em Mateus. Também a oferta dos presentes pode estar associada ao verso do Salmo 71 (10 - “[...] os reis da Arábia e de Sabá Ihe trarão presentes $11-\mathrm{E}$ adorá-lo-ão todos os reis da terra"). Nesse contexto dos textos bíblicos, foram incorporados tipos e figuras pertencentes ao povo e fatos do cotidiano das aldeias, bem como os grandes personagens e acontecimentos da história.

\subsubsection{As Folias}

Em Portugal, os Autos Natalinos e os Presépios já eram conhecidos desde o século XIV, "mas as primeiras notícias das Folias, tal como a conhecemos hoje, remontam ao século XVI". (GONÇALVES, 2008). Antes, as folias estavam vinculadas a festas pagãs. Eram grupos que se deslocavam, cantando, dançando e pedindo donativos. Já eram práticas incorporadas ao imaginário popular, principalmente na península Ibérica. Pelo seu caráter deambulatório e precatório, atribuiu-se a origem das Folias a costumes medievais como o de mestres, estudantes e boêmios percorrerem a Europa mendigando, se divertindo, durante os séculos XII ao XIV. (GONÇALVES, 2008).

Em outra versão, os ciganos são apontados como possíveis raízes dessa prática cultural, não só pelo seu nomadismo, mas também pelos instrumentos, estandartes, fitas e flores coloridas que os caracterizam. 
(GONÇALVES, 2008). Desse modo as encenações religiosas vinculadas aos autos da natividade e dos Reis Magos, passaram a ser precedidas ou sucedidas pelas folias.

Países como França, Inglaterra, Bélgica, Alemanha, Itália, Espanha e Portugal, entre outros, festejam os Reis Magos. Em alguns desses países, principalmente os ibéricos, a festa de Reis possui maior importância do que o próprio Natal; é no dia seis, que os presentes são trocados, visitas aos parentes realizadas, fartos banquetes preparados e, nas igrejas, suntuosas celebrações realizadas. Essas festividades, em Portugal, também estão vinculadas ao Mito do Sebastianismo.

Surgido no século XVI em Portugal, o mito de D. Sebastião está associado à volta de uma época farta, próspera e de paz entre todos. Duas comemorações festivas populares associam-se à crença deste mito messiânico: a Folia do Divino (ou Festa do Divino) e a Folia de Reis (ou Festa de Reis). Ambas as folias incorporam em seu bojo características do "espírito do sebastianismo", e são, ainda, praticadas em Portugal. Nelas estão presentes crenças na fartura, proteção para as colheitas e para as famílias, a chegada de uma espiritualidade positiva - um pacto com o sagrado é elaborado - o compartilhar um banquete com o outro, a subversão de uma ordem de poder onde é coroado um membro do povo, e, assim, se faz renascer a certeza de que as solicitações serão atendidas e que um mundo melhor será desencadeado.

Em suma, as origens dionisíaca, janual, saturnal e sebastianista são revividas no Espírito Consolador do Divino Espírito Santo e dos Três Reis. Os Reis Magos são considerados os primeiros santos do cristianismo e a sua 
santificação é atribuída ao encontro com o Divino (Menino Deus). Foram santificados pela esperança, pelo contato com a renovação, e essa santificação contradiz a pregação da Igreja romanizada, que atribui a salvação e a redenção dos pecados ao sangue derramado por Cristo em sua crucificação, assim como ao martírio e morte dos Santos.

A devoção aos Reis acompanha o imaginário popular desde os primórdios da expansão do pensamento cristão, sempre vinculada à redenção pela vida. Portanto, ao longo dos tempos, as celebrações populares que comemoravam a vida através das festas pagãs foram incorporadas à liturgia da Igreja romanizada. O ciclo natalino possibilitou a transferência das festas de tradições populares para a liturgia oficial.

Desse modo, o presépio acaba sendo uma encenação dos fatos bíblicos através da disposição visual de seus personagens. A montagem e desmontagem dos personagens desencadeiam em muitas comunidades um momento de agregação e muitos rituais e crendices são mantidos. A origem do presépio é atribuída a São Francisco de Assis (1181/82 - 1226).

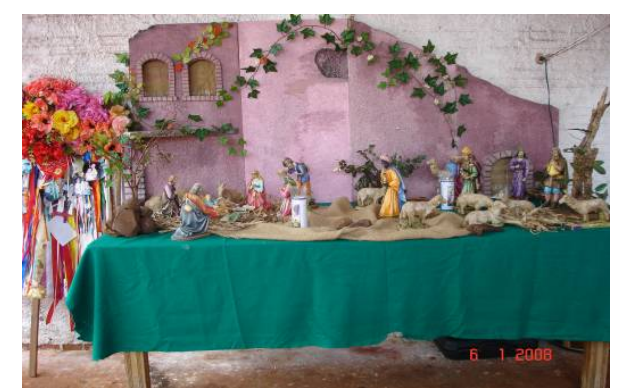

Foto 3.3: Presépio para receber a bandeira de Reis $^{42}$

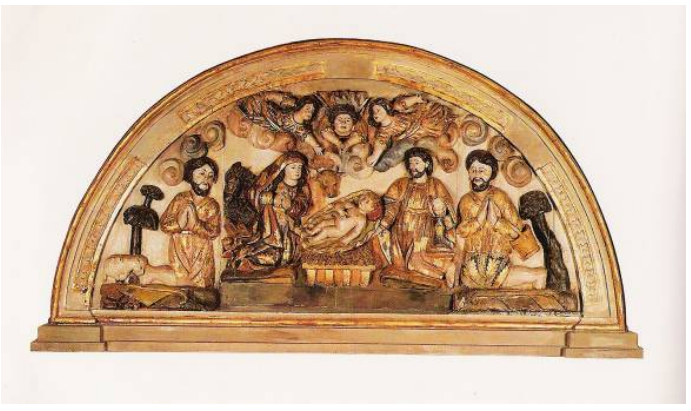

Imagem 3.14: Presépio em alto relevo, $1680^{43}$

\footnotetext{
42 Presépio montado para receber a bandeira do Divino da Companhia dos Faceiros, cidade de Palmital/SP. Foto da autora, Janeiro de 2008.

43 Adoração dos pastores, 1680. Alto relevo em madeira policromada e dourada. $103 \times 210 \times 14 \mathrm{~cm}$. Procedente da antiga Sé da Bahia, Arquidiocese de São Salvador/BA. Museu de Arte Sacra da Universidade Federal da Bahia/BA in Universo Mágico do Barroco Brasileiro, Emanoel Araújo (curador) - São Paulo: SESI, 1998, p.108.
} 


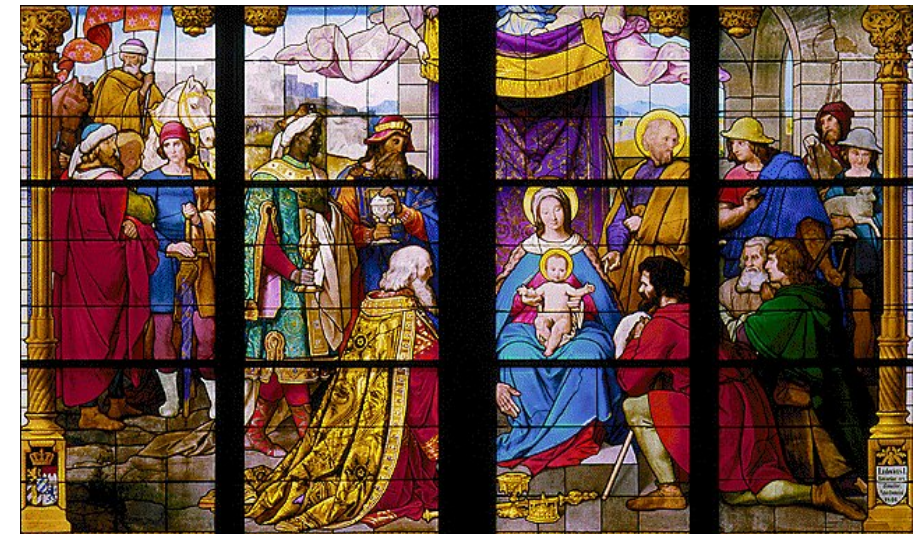

Imagem 3.15: Vitral com motivo de presépio, 1846. Catedral de Colônia - Alemanha ${ }^{44}$

Em muitas comunidades onde o presépio é armado, mantém-se um ritual de só colocar o menino Jesus no presépio no dia 25 de dezembro e todas as figuras são dispostas indo para cena do nascimento. Após o dia primeiro, os Reis Magos são colocados próximos da cena do nascimento. E as outras figuras no sentido contrário, saindo da cena de visitação, no dia 6 de janeiro os Reis são colocados na gruta e o presépio é desarmado nos dias subseqüentes.

Essas tradições possuem variações nas comunidades, mas todas as crenças atribuem o dia 6 de Janeiro ao dia de se fazer "simpatias" para obtenção de bens materiais, para proteção da casa e das lavouras. Duas crendices são comuns: a de se escrever o nome dos reis num papel branco e colocar nas portas da residência, pedindo proteção e prosperidade e a de se chupar três grãos de romãs ao meio dia, pedindo aos Três Reis - Baltazar, Gaspar e Melchior -, fartura e dinheiro durante o ano. As sementes devem ser guardadas dentro das carteiras.

\footnotetext{
44 Vitral com motivo de presépio e visitação dos Magos, 1846, Catedral de Colônia - Alemanha. Disponível em: <http://www.koelner-dom.de/index.php?L=1\&id=18388>. Acesso em: 02 de outubro de 2008.
} 


\subsubsection{Sobre os Reis}

Foi no dia 06 de janeiro de 1164 que a comemoração da peregrinação dos Reis Magos para visitar o menino Deus foi oficializada. Nos primórdios do cristianismo havia controvérsias quanto ao número de magos que tinham visitado o menino Jesus. Mas, no Século III, no ano 213 o teólogo Orígenes, baseado no número de presentes oferecidos, indicados na narrativa evangélica (Is. 60,1-6; Mt. 2,1-12) ${ }^{45}$ definiu em três o número dos magos. No texto da bíblia, os reis ofertaram três presentes: Mirra - óleo com o qual eram ungidos os reis e os mortos; Ouro - símbolo do poder, do divino, da perfeição e da imortalidade e Incenso - usado universalmente como associação do homem à divindade, do finito ao infinito, do mortal ao imortal (CHEVALIER; GHEERBRANT, 1997). Na Igreja romanizada, os presentes ofertados simbolizam: o ouro a realeza, o incenso a divindade e a mirra a paixão de Cristo.

Ainda, na tradição cristã, os Magos foram os primeiros portadores do poder e do conhecimento a reconhecer a divindade de Jesus. $\mathrm{Na}$

\footnotetext{
${ }^{45}$ Isaías 60,1-6. "Glória de nova Jerusalém. Levanta-te, recebe a luz, Jerusalém, porque chegou a tua luz, e a Glória do Senhor nasceu sobre ti. Porque eis que as trevas cobriram a terra, e a escuridão os povos; mas sobe ti nascerá o Senhor, e a sua glória se verá em ti. Nações caminharão à tua luz, e os reis, ao resplendor da tua aurora. Levanta em roda os olhos e vê: todos esses se congregaram, vieram a ti; teus filhos virão de longe, tuas filhas surgirão de todos os lados. Então tu verás, estarás na abundância, o teu coração se espantará e se dilatará fora de si mesma quando se voltarem para ti as riquezas do mar e a fortaleza das nações vier ter contigo. Ver-te-ás inundada duma multidão de camelos de dromedários de Madiã e de Efa; todos virão de Sabá, trazendo-te ouro e incenso, e publicando os louvores do Senhor."

Mt. 2,1-12. "Tendo, pois, nascido Jesus em Belém de Judá, no tempo do rei Herodes, eis que uns magos chegaram do oriente a Jerusalém dizendo: Onde está o rei dos judeus, que acaba de nascer? Porque nós vimos sua estrela no oriente e viemos adorá-lo. Ao ouvir isso o rei Herodes turbou-se e toda Jerusalém com ele, e, convocando todos os príncipes dos sacerdotes e os escribas do povo perguntou-lhes onde havia de nascer o Messias. E eles disseram-lhe: em Belém de Judá, porque assim foi escrito pelo profeta: "E tu, Belém, terra de Judá, de modo algum é menor entre as principais (cidades) de Judá, porque de ti sairá um chefe que apascentará Israel, meu povo."[...] Vendo (novamente) a estrela ficaram possuídos de grandíssima alegria. E, entrando na casa, viram um menino com Maria, sua mãe, e, prostrando-se, o adoraram; e, abrindo-se seus tesouros, Ihe ofereceram presentes (de) ouro, incenso e mirra."
} 
antiga Pérsia os reis eram conhecidos como Magos e no evangelho de Mateus

ele usa o termo "mago", esta constatação levou muitos estudiosos a supor que

os magos tinham vindo do oriente. $\mathrm{Na}$ antiguidade, em muitos registros, o

Oriente está identificado com a Arábia, Mesopotâmia, Babilônia e ou Pérsia.

Essas suposições confirmam profecias e relatos do antigo testamento, como a encontrada no Salmo $71^{46}$.

No Ocidente, no século IV, por volta do ano 361, outro

historiador e teólogo do cristianismo, Tertuliano de Cartago fala que os Reis, vieram da Tarsis, Arábia e Sabá, provavelmente baseado também no Salmo 71; Tarsis - Melchior, Arábia - Gaspar e Etiópia - Baltazar, mas é atribuído ao teólogo São Bedas, que viveu de 673 a 735, a citação dos nomes dos Reis e a elaboração de suas descrições.

Após os escritos de São Bedas a tradição também atribuiu uma característica étnica a cada rei, Gaspar é identificado como tendo olhos amendoados, pele morena e barba fina, Baltasar era negro e imponente e Melchior como sendo o mais velho dos três, de longa barba branca e pele clara. Na Basílica de San Apollinare Nuovo em Ravena, os nomes de Gaspar, Melchior e Baltazar aparecem nos mosaicos.

\footnotetext{
${ }^{46}$ De Salomão. Ó Deus, confiai ao rei os vossos juízos. Entregai a justiça nas mãos do filho real, para que ele governe com justiça vosso povo, e reine sobre vossos humildes servos com eqüidade. Produzirão as montanhas frutos de paz ao vosso povo; e as colinas, frutos de justiça. Ele protegerá os humildes do povo, salvará os filhos dos pobres e abaterá o opressor. Ele viverá tão longamente como dura o sol, tanto quanto ilumina a lua, através das gerações. Descerá como a chuva sobre a relva, como os aguaceiros que embebem a terra. Florescerá em seus dias a justiça, e a abundância da paz até que cesse a lua de brilhar. Ele dominará de um ao outro mar, desde o grande rio até os confins da terra. Diante dele se prosternarão seus inimigos, e seus adversários lamberão o pó. Os reis de Társis e das ilhas lhe trarão presentes, os reis da Arábia e de Sabá oferecer-lhe-ão seus dons. Todos os reis hão de adorá-lo, hão de servi-lo todas as nações. Porque ele livrará o infeliz que o invoca, e o miserável que não tem amparo. Ele se apiedará do pobre e do indigente, e salvará a vida dos necessitados. Ele o livrará da injustiça e da opressão, e preciosa será a sua vida ante seus olhos. Assim ele viverá e o ouro da Arábia lhe será ofertado; por ele hão de rezar sempre e o bendirão perpetuamente. Haverá na terra fartura de trigo, suas espigas ondularão no cume das colinas como as ramagens do Líbano; e o povo das cidades florescerá como as ervas dos campos. Seu nome será eternamente bendito, e durará tanto quanto a luz do sol. Nele serão abençoadas todas as tribos da terra, bem-aventurado o proclamarão todas as nações. Bendito seja o Senhor, Deus de Israel, que, só ele, faz maravilhas. Bendito seja eternamente seu nome glorioso, e que toda a terra se encha de sua glória. Amém! Amém! Aqui terminam as preces de Davi, filho de Jessé.
} 
A devoção aos Reis está vinculada ao cristianismo primitivo. Foram encontrados desenhos simbolizando a visitação dos reis em catacumbas da época protocristã, como na catacumba de Santa Domitilla em Roma. Nela, aparecem quatro magos representados. Mas, o que intriga os estudiosos é: como um relato específico e pequeno, de um único evangelista pode desencadear uma devoção tão antiga e arraigada no imaginário popular?

Nas histórias populares, cada rei também estava vinculado a uma nacionalidade ou continente do mundo conhecido da época medieval, Grécia - Europa, Índia - Ásia e Egito - África. Ainda, segundo a oralidade, os Magos são descendentes diretos de Jó. No Auto dos Reis Magos, Gil Vicente, pela fala do "ermitão", que representa a Igreja romanizada na peça, faz uso das profecias de Isaías e do Salmo 71 que inspirou a origem dos Reis.

Da popularidade das Folias em Portugal nas primeiras décadas do séc. XVI há significativa documentação em diferentes textos, como em Gil Vicente (1465-1536) que faz referências sobre folias, a visita dos reis e sobre o presépio em textos como:

\author{
FRÁGUA DE AMOR ${ }^{47}$ \\ Parece-me bem bailar \\ E andar n'uma folia \\ Ir a cada romaria \\ Com mancebos a folgar. \\ (VICENTE, 1965, p.1077)
}

AUTO DA SIBILA CASSANDRA ${ }^{48}$
$[\ldots .$.
Traz Salomão Esaias a Moyses e Abrahão, cantando todos
Quatro de folia a cantiga seguinte:

Que sañosa está la nina!

Ay Dios quien le hablaria!

[...]

\footnotetext{
47 Trecho da tragicomédia Frágua de Amor, 1525, de Gil Vicente.

48 Trechos do Auto da Sibila Cassandra, 1511. Esta obra pouco conhecida de Gil Vicente retrata um auto natalino, com características cômicas, onde canções e músicas são apresentadas em forma de folia.
} 
Abrem-se as cortinas onde está todo o apparato do Nascimento, e cantão quatro Anjos.

[...]

Vão cantando em chacota, e chegando a presépio diz:

(VICENTE, 1965, p.139-164)

\author{
AUTO DOS REIS MAGOS ${ }^{49}$ \\ [...] \\ Y no sé ser sabidor \\ Adó nació el Salvador \\ Trece dias son pasados, \\ Bien contados \\ $[\ldots]$ \\ O profeta Isayas, \\ Bien decias. \\ Levántate á ser alumbrado, \\ Hierusalen visitada \\ [...] \\ David nel salmo setenta \\ Y uno cuenta, \\ Reis de Tarsis y Sabá, \\ Y el de Arabia verná \\ Con humildá, \\ Muy gran compaña sin cuenta, \\ Adorar sin mas afrenta \\ Muy contenta. \\ De oro llevan gran presente, \\ Incenso, mirra excelente, \\ Humildemente. \\ [...]
}

"Apparecem os tres Reis Magos cantando o seguinte Vilancete:

Cuando la Virgem bendita Lo parió,

todo el mundo lo sentió.

Los coros angelicales

Todos cantan nueva gloria;

Los tres Reis la vitoria

De las almas humanales.

En las tierras principales se sonó,

Cuando nuestro Dios nació.

E cantando assi todos juntamente, offerecem os Reis seus presentes; e assi mui alegremente cantando se vão. E acaba em breve, porque não houve espaço pêra mais."

(VICENTE, 1965, p.27-39)

Nas lendas e tradições do medievo os Três Reis se reencontram após 50 anos em Sewa, uma cidade da atual Turquia e são tidos e citados como os primeiros convertidos a pregar os ensinamentos cristãos; peregrinaram pela Ásia Menor evangelizando, faleceram e foram sepultados

\footnotetext{
${ }^{49}$ Trechos do Auto dos Reis Magos, 1503. Obra idealizada para encenação no dia de Reis.
} 
em Sewa. De lá, seus corpos foram transportados como relíquias para Constantinopla e depois para a igreja de Santo Eustórgio em Milão no século VI. No século XII, o Imperador Germânico, Frederico Barba-Roxa (1152-1190) invadiu Milão e por volta de 1164 as relíquias dos Reis foram levadas para Colônia (Alemanha) pelo Arcebispo Rainald von Dassel e no dia 23 de julho desse ano foram depositadas na antiga catedral.

$\mathrm{Na}$ atualidade é possível visitar as relíquias dos Reis, guardadas em uma rica urna no Altar-Mor da catedral de Colônia. Os estudiosos não são capazes de precisar de quem sejam os corpos depositados na urna em Colônia. A urna dos Reis é considerada, juntamente com a urna que guarda os restos do imperador Carlos Magno, um dos maiores tesouros da arte medieval. Foi confeccionada em ouro e pedras preciosas, projetada e iniciada em 1181 pelo mestre ourives Nikolaus von Verdun, e concluída em 1220, por seus seguidores. A atual catedral de Colônia foi iniciada em 1248 e finalizada em 1880 por Guilherme I, imperador da Prússia, convertendo-se em um dos maiores centros de peregrinação da Idade Média; hoje é considerada como uma das mais ricas, altas e bela construção gótica.

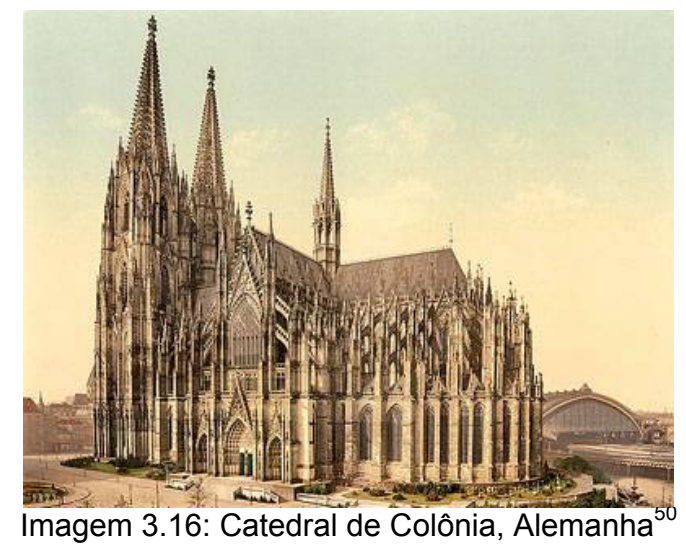

\footnotetext{
${ }^{50}$ Fotocromo da Catedral de Colônia, tirada em 1890, dez anos após sua conclusão Fonte: Biblioteca do Congresso dos Estados Unidos. Disponível em:< http://www.helderdarocha.com.br/blog/2006/07/catedralde-colnia.html>. Acesso em: 15 de junho de 2008.
} 

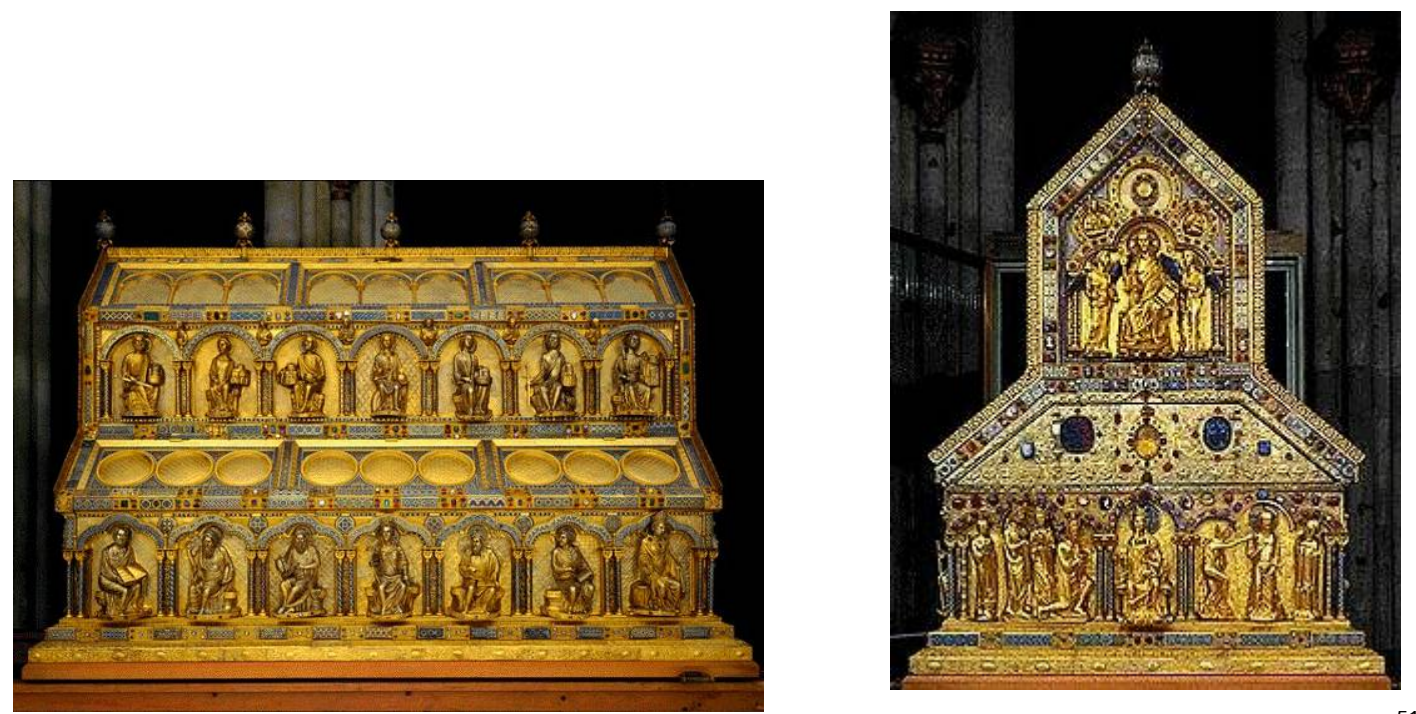

Imagem 3.17: Vista lateral e frontal do Relicário dos Reis Magos, Catedral de Colônia, Alemanha ${ }^{51}$

Da devoção aos Reis Magos se originaram muitas comemorações, festividades e crenças, bem como, tradições que chegaram até o presente em toda a Europa, Ásia e principalmente na América Latina. Estudos demonstram que essas festas guardam semelhanças. Em Portugal a pesquisadora e escritora portuguesa Soledade Martinho Costa coletou e documentou as festas populares portuguesas da atualidade. Este trabalho resultou em uma coleção de oito volumes: Festas e Tradições Portuguesas: Ritos, Memória e Identidade, Ed. Círculo de Leitores. Escritos por ela e ilustrados com as fotos de outro pesquisador, Jorge Barros, as festas são descritas seguindo os meses do ano: "um mês nunca é igual a outro mês. Cada mês tem a sua própria personalidade. Os antigos tinham mesmo imagens delineadas, com atributos próprios, para cada um dos meses." (COSTA, 2002). No primeiro volume, as festividades de janeiro são descritas e, em muitas, os ecos das Folias são encontrados.

51 Relicário dos Três Reis Magos, Catedral de Colônia, Alemanha, 1190-1220. Disponível em: <http://www.koelner-dom.de/index.php?id=dreikoenigenschrein\&L=1>. Acesso em: 15 de junho de 2008. 
Ainda hoje, é comum a troca de presente nos dias de Reis, bem como a troca de presentes durante as festividades de fim e início de ano. Em muitas comunidades é corriqueiro ofertar moedas, no e ao presépio e efetuar uma troca de moeda - a moeda trocada é guardada como símbolo de fartura e sorte durante aquele ano. No Brasil pedir uma moeda (ano bom), ou (um dinheirinho) no dia primeiro do ano, é pratica ainda existente em muitas comunidades, mantida principalmente pelas crianças das vilas e bairros mais pobres.

São também os Reis que batizam o manjar cerimonial da doçaria alimentar desta data: o «Bolo-Rei», espécie de pão doce recheado e enfeitado com frutos secos e cristalizados, cuja tradição se espalhou por quase toda a Europa e alguns países da América (particularmente da América Latina).

Supostamente, a resultar do bolo janual, que os Romanos ofereciam e trocavam entre si nas festas do primeiro dia do Ano Novo. Ao bolo juntavam um ramo de verdura colhido num bosque dedicado à deusa Strénia ou Strena. Do nome da deusa resultará o vocábulo francês étrenne (que significa "presente de Ano Novo") e a palavra "estreias", termo que, em certas localidades do nosso país, continua a utilizar-se para definir o acto de oferecer presentes de "boas festas" ("dar as estreias"). (COSTA, 2002, p.120).

Nas tradições populares da Europa, principalmente nos hábitos alimentares e na organização das festas, somaram-se as crenças da Igreja romanizada, assim como os costumes oriundos do medievo, das grandes encenações religiosas, e os das folias. Gil Vicente cita no Auto dos Reis Magos o personagem Gregório procurando o menino por treze dias; esses dias estão vinculados ao "ciclo dos doze dias" citado pela autora, período em que transcorrem as festas de Reis.

Se recuarmos no tempo, deparamos com as "estreias" (atrenua) relacionadas com mascaradas, banquetes, jogos e outras celebrações realizadas pelos povos pagãos. Daí, no Concílio de Tours, em 567, ter sido sugerido que as "estreias" pagãs dessem lugar "às esmolas de carácter cristão e litúrgico", de modo a atenuar os vestígios do politeísmo Ao bolo janual e ao ramo de verdura acrescentavam os Romanos pequenas lembranças (tâmaras, figos, mel), com votos de bom ano, paz e felicidade. Este costume tornou-se depois mais 
exigente, acabando o ouro e a prata por substituir os singelos presentes.

Em diversos países foi hábito durante muito tempo introduzir no bolo uma pequena cruz de porcelana que se juntava à fava, símbolo da fortuna, substituída depois por minúsculas figurinhas humanas. Tradição que se mantém, introduzindo no bolo um qualquer objecto minúsculo apropriado para esse efeito. Associados à quadra natalícia, mais propriamente ao chamado "Ciclo dos Doze dias» (que medeia o Natal e o Dia de Reis), vamos encontrar as «janeiras» e os «reis», que representam peditórios cantados na noite de Natal, de Ano Novo e de Reis. (COSTA, 2002, p.123).

Nesta época do ano, os autos e cantorias, bem como as danças, são intensificados em toda a Europa, assim como nas Américas e no Brasil. É também a época reservada para o encontro com as famílias e conseqüentemente propícia para a manutenção das tradições.

\begin{abstract}
Herança provável das próprias strenas romanas, a entoação dos cânticos tem por finalidade receber dádivas que se revestem de um carácter alusivo e propiciatório, a remeter-nos, como noutras celebrações, para tempos remotos, em que se celebravam deuses e divindades pagãs ou eram pedidas ou oferecidas dádivas no início do ano comum, símbolo de bom augúrio, quer para quem as pedia, quer para quem as doava.

O costume, espalhado por toda a Europa em países como Portugal, Espanha, França, Itália, Alemanha, entre outros, continua a efetuar-se, com os seus seculares cânticos de religiosidade popular e festiva. (COSTA, 2002, p.123).
\end{abstract}

As folias, portanto, podem ter suas raízes em várias tradições

herdadas de diferentes culturas; certo é que são festividades que integram o lúdico, o religioso, o profano, e agregam os membros de uma comunidade. São encontradas em Portugal, segundo Costa (2002), em diferentes regiões, com diversas denominações.

Formados por grupos de homens e mulheres, os "janeireiros" e "reiseiros", acompanhados ou não por músicos, percorrem os lugares, de porta em porta, a pedir oferendas em troca da entoação das «loas» ao Menino, às Janeiras e aos Reis.

«Cantar os Reis», "esperar os Reis», «correr os Reis» ou «tirar os Reis», são as denominações decorrentes destas praxes.

Também as «reisadas» e as "chocalhadas» se articulam no mesmo contexto, não deixando, ainda hoje, de fazer a sua aparição pelas nossas vilas, aldeias e lugarejos. As primeiras, constituídas por grupos (mais aproximadas às «janeiras»), apresentam maior incidência na 
Beira Baixa, Estremadura e Ribatejo, embora façam a sua aparição noutras zonas do país. As segundas, efetuadas igualmente por grupos, têm por finalidade a barulheira e a gritaria festivas, com o bater de latas e outros objectos barulhentos e o soar de campainhas, chocas e chocalhos, enquanto procedem ao tradicional peditório "para os Reis». Noutros casos, o mesmo gênero de grupo limita-se à infernal barulheira, omitindo as dádivas.

Com esta função, pretende-se, uma vez mais, pelo barulho, afugentar o mal e obter benefícios propiciatórios e profilático (à semelhança do ritual da noite da passagem de ano, com o bater de latas, de panelas, etc.).

As «chocalhadas» levam-nos às Sigilárias ou Festas Sigilares de Roma (sigilar de "fechar», em alusão ao "fechar do Ano Velho»), realizadas no primeiro dia de Janeiro, em que se fazia enorme barulho à porta de casa de cada um.

Igualmente provável é a celebração dos Reis resultar de antigos rituais ligados ao culto dos politeístas solares e da sua festa de consagração da luz do Sol no solstício de Dezembro, efetuada no Egito sob o título Festum Osirid nati, ou Inventio Osirid, em data correpondente ao nosso 6 de Janeiro, designada pelos Judeus como Festa das Luzes ou Khanu Ka. (COSTA, 2002, p.125).

\subsubsection{Folia de Reis no Brasil}

Com a chegada dos portugueses, desembarcaram no Brasil também as comemorações da natividade e dos Reis Magos. Os primeiros jesuítas, como os padres Manoel da Nóbrega e José de Anchieta, usavam as folias e autos de dramatização nas festividades e nas procissões, muitos escritos na língua geral. Da devoção aos Reis, surge as Companhias de Folias de Reis ou Confrarias, onde os elementos sagrados e profanos caminhavam juntos, evoluindo de acordo com as características culturais das localidades. $\mathrm{O}$ relato de Moraes Filho (1979) - A Coroação de um Rei Negro em 1748 servirá como elemento descritivo, neste tópico, dos levantamentos históricos realizados sobre as Folias no Brasil. Portanto algumas citações são apresentadas como documentos descritivos das características das Festas de Reis, desde sua origem. Algumas citações apresentam-se longas no corpo do 
texto, para não se perder a idéia de historicidade. O texto, na íntegra, se encontra em anexo.

Quase às dez horas acendiam-se os altares, o capelão revestia-se, os sinos repicavam, e os irmãos do Santo Rei Baltasar, com suas opas de seda, esperavam no corpo da igreja, dobrando língua, batendo boca entre si.

Em breve, a vozeria confusa que se escutava lá fora, calava-se; os sinos repicavam mais vibrantes e rápidos, produzindo esta mudança do efeito o rolar surdo das caixas de guerra, o som de rapa das macumbas em grande número, a queda sonoramente uniforme dos chocalhos enfeitados da bárbara marcha precedendo o préstito.

De braços erguidos, pulando e revirando sobre as mãos, vestidos de penas e estofos coloridos, quatro muanas (negrinhos) serviam de batedores ágeis, fazendo negaças, cantando, gritando...

Atrás da música caminhavam majestosamente e Neuvangue (rei), a Nembanda (rainha), os Manafundos (príncipe), o Endoque (feiticeiro), os Uantuafunos (escravos, vassalos e vassalos do rei), luzido e vigoroso grupo daquelas festas tradicionais e genuinamente africanas, celebradas no Rio de Janeiro no século passado.

$[\ldots]$

Ao feiticeiro, enrolando e desenrolando em torno do pescoço enorme cobra, envergando vestimentas de peles e rubro cocar, olhando misteriosamente, volteavam-lhes o antebraço e o colo fieiras de miçangas e de pequenos búzios, entremeadas de figas e talismãs de rosário e bentinhos.

A turba-multa que os acompanhava fechava o magno cortejo, do qual somente o Rei, a Rainha, os príncipes e os vassalos entravam, sendo aqueles para serem coroados na Igreja.

[...]

Do mesmo arquivo da Lampadosa, no citado Compromisso da Irmandade do Santo Rei Baltasar, encontrava-se entre muitos, este termo, que reproduzimos e que demonstra que na referida capela esses costumes conservaram-se até muito mais tarde,[..] (MORAES FILHO, 1979, p. 226-227).

A hibridização acontece, principalmente com a forte

característica das práticas animistas pertencentes às culturas dos povos

originários e africanos. Estas culturas tinham e têm como particularidade a concretude de sua espiritualidade através de imagens iconográficas. Portanto, no início da catequização, a Igreja Portuguesa, estruturada como conseqüência da contra-reforma e marcadamente influenciada pelo barroco, fez uso constante de uma prática litúrgica centrada na veiculação imagética, renovada a cada procissão, que se fundiram com os simbolismos e imagens criadas através das dramatizações e festas promovidas pela Igreja Jesuíta. 
A catequização dos povos originários pelos jesuítas alcançava melhores resultados quando estes utilizavam os recursos da imagem para explicar o nascimento do Menino Deus. A utilização e montagem do presépio eram desta forma, mais didática e de melhor compreensão. Nesta direção, observou Sebastião Rios (2006, p. 67):

Com a consolidação da colonização, os rituais usados na catequese do índio disseminaram-se entre colonos portugueses, negros escravos e mestiços de toda sorte e foram incorporados às festas dos padroeiros.

Os Reis Magos se fazem presentes no Brasil desde o início de sua colonização. Uma comprovação desta presença é o fato do Forte dos Reis Magos, em Natal/RN, ter sido fundado em 06 de janeiro de 1598 sob sua proteção, marcando provavelmente a introdução do culto aos Santos Reis no país. Ainda no século XVIII, chegam as primeiras imagens dos Reis Magos ao Forte. Também pelo relato abaixo, percebe-se que a devoção aos reis era comum na colônia:

\section{A Coroação de um Rei Negro em 1748}

Em 1742, fundou-se no campo de São Domingos a Capela de Nossa Senhora da Lampadosa, sendo bispo do Rio de Janeiro D. Fr. Antônio do Desterro.

O terreno para a fundação foi cedido pelo Senado da Câmara à irmandade da mesma Senhora, que, por funcionar no Rosário, isso requere e obteve.

Do primitivo templo, bem raras são as relíquias; quase que não existem pedra sobre pedra.

Como preciosidades históricas há a imagem da excelsa padroeira, a do Santo Rei Baltazar, um Apóstolo do Mestre Valentim, e um admirável retrato a óleo do Marquês de Pombal, obra-prima da arte antiga.

O mais o vandalismo destruiu... (MORAES FILHO, 1979, p. 225). 


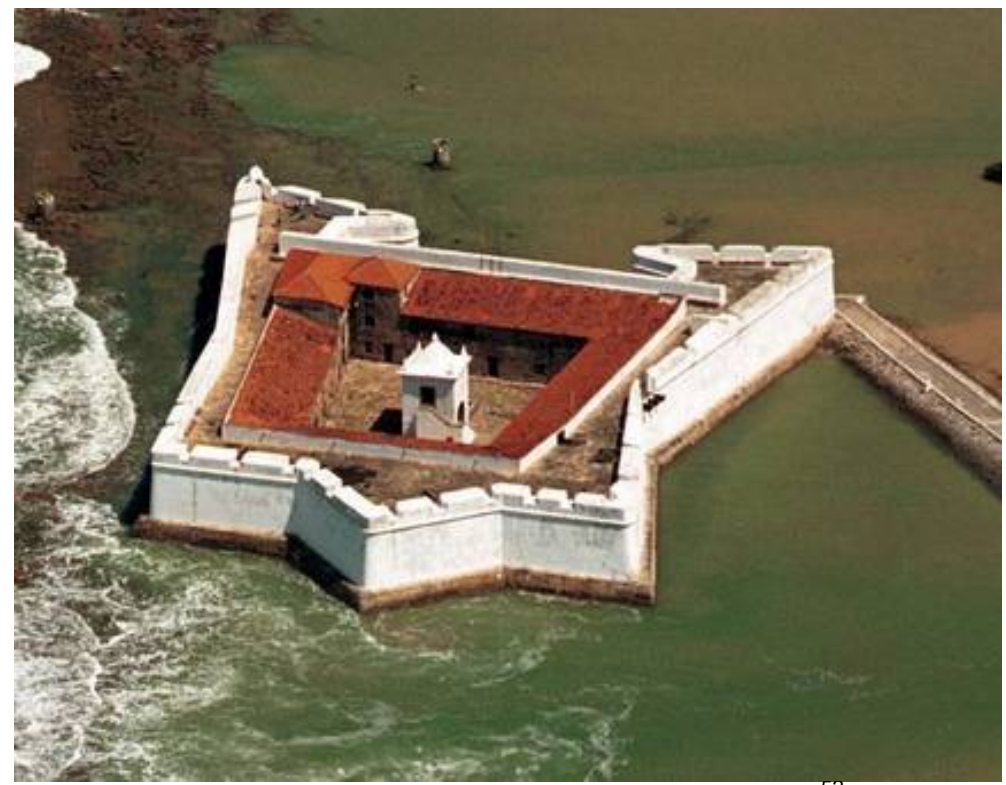

Imagem 3.18: Forte dos Reis Magos, Natal/RN ${ }^{52}$

Em decorrência da popularização dos Autos vinculados à Natividade tanto na península Ibérica quanto no Brasil, as Folias de Reis possuem variações em diferentes regiões do país, bem como, de denominações: Ternos de Reis, Pastorais do Senhor Menino, Folias e Reisadas, Bois de Reis, Reisados, Pastoris, Bailes Pastoris e Companhia de Reis.

Com o nome de Folia, existe no Brasil um grande número de grupos devocionais dos santos católicos: São Sebastião, São Benedito, São José, Divino Espírito Santo, Festa do Rosário, Festa de São Gonçalo e Santos Reis.

Segundo Câmara Cascudo (2001, p. 242), folia é uma dança rápida ao som do pandeiro ou adufe,

um grupo de homens, usando símbolos devocionais, acompanhando com cantos [...] festejando-lhe à véspera [...] não tem em Portugal o aspecto precatório da folia brasileira,

\footnotetext{
52 Disponível em:

<http://www.pedrassoli.com.br/news/images/stories/tours/city_tour/Forte_dos_Reis_Magos.jpg>.Acesso em: 23 de outubro de 2008. Sua forma arquitetônica remete para o formato de uma estrela.
} 
mineira e paulista [...] é uma espécie de confraria, meio sagrada, meio profana, instituída para implorar a proteção divina [...].

Era comum dar e receber presentes entoando cantos e danças ou apenas pedindo esmola e alimentos.

No Brasil, a área de maior incidência tem sido a região Sudeste, principalmente no interior dos estados de Minas Gerais, Rio de Janeiro e São Paulo. O dia de Reis marca oficialmente o fim do ciclo natalino com uma grande comemoração onde as prendas arrecadadas durante a peregrinação são compartilhadas com a comunidade. Essa distribuição dos presentes e o almoço servido também remetem às celebrações antigas já mencionadas. Os grupos de Folias de Reis são formados por cantores e instrumentistas que, na época do Natal, saem em peregrinação. O ritual é complexo e guarda ligações (muitas vezes tênues) com a tradição européia, como o teatro, música e dança, herdados da cultura portuguesa.

Participar de uma companhia de Reis é antes de tudo um ato de fé; a Folia vai além da representação. Seu sentido primordial é o místico, é a devoção. Este sentido religioso a caracteriza e lhe imprime um dinamismo peculiar, que permite sua sobrevivência na atualidade, mesmo sofrendo as influências culturais próprias dos regionalismos e das dinâmicas tempestivas dos processos vinculados aos meios massivos e globalizados da atualidade. Fatores que colaboraram ao longo dos tempos para que sofressem modificações e, na atualidade, apresentam características próprias.

Os grupos de foliões são compostos, geralmente, por três homens fantasiados, representando os magos; um ou mais palhaços relacionados a Herodes e soldados, sempre mascarados. 
Em algumas apresentações esses personagens estão ligados à natureza maligna do homem ou ao mal, em outras podem ser os defensores do Menino Jesus. Acompanha esses personagens um mestre que comanda os foliões e estabelece as regras. É dele a função de puxar os versos que serão repetidos pelos outros membros do grupo, tocadores ou orquestra composta de banjo, violão, viola, zabumba, caixa, triângulo, pandeiro, maracás, sanfona, rabeca, cavaquinho e flauta de taquara, cantores e porta-bandeira, também conhecido como alferes, que tem ainda a incumbência de orientar as pessoas das casas e, às vezes, receber as doações.

Para a realização das Folias, há ainda dois elementos importantes: o festeiro, que é o responsável pelo início e encerramento, e o gerente, que antecipadamente organiza o roteiro ou percurso, o giro das folias. É dele a função de entrar em contato com a comunidade e saber quais as casas que querem receber a bandeira, quais oferecerão almoço para os foliões e as que oferecerão o pouso. Ele também pode se encarregar de receber e recolher os donativos.

Uma das exigências ou crendice para participar de uma folia é que o folião deve permanecer nela por sete anos seguidos, sob pena de ser punido pelos Reis ou atrair má sorte. Após esse período, o devoto pode tornarse mestre ou estar livre da obrigação com o grupo. A participação nas folias é motivada pela paga de promessas ou para fazer pedidos ao menino Jesus e aos Santos Reis. No imaginário popular, os pedidos adquirem características de troca: solicitar a proteção ou a intercessão de um Santo é motivo de lhe ofertar algo em troca. Desta maneira, os Santos podem cobrar o que Ihes foi prometido. Muitas vezes, maus acontecimentos da vida do solicitante são 
encarados como castigos pelas promessas não cumpridas. Como nas folias o que é oferecido aos Santos Reis são quase sempre as prendas para as festas; é comum, a crença de que os egoístas e as promessas não cumpridas de ofertas gerem castigos ou, como dizem, "leve a vida pra trás".

Em algumas companhias é permitida a presença de mulheres. Mas, normalmente a elas cabe preparar os alimentos, as casas para receber os foliões, armar os presépios, responder a reza dos terços, e elaborar a decoração e arranjos no dia da festa. As folias peregrinam pelas casas dos devotos, que se sentem abençoados pela visita da bandeira e pelas orações. Ao chegar, entoam-se cantos de saudação aos donos da casa e em louvor ao Menino Jesus, pedindo proteção e bênção. Após o ato sagrado, realiza-se uma apresentação de danças profanas, geralmente a catira.

Há diferentes indumentárias para os grupos, Garbosi (2002) aponta a necessidade, na atualidade, do uso de um uniforme, para proteger os foliões de possíveis intrusos alheios ao sentido religioso da folia. As músicas têm como base de suas letras os acontecimentos da natividade descritos no Novo Testamento.

Nas pesquisas realizadas para verificar a evolução das Folias de Reis, bem como nas pesquisas de campo, foram detectados elementos de caráter imutável: são esses elementos presentes, em diferentes relatos, em diferentes épocas, que sustentam a fé e fazem a Folia de Reis ser reconhecida e realizada em todas as regiões do país.

Sua mensagem de messianismo, anunciando e dando esperança de dias melhores é um forte alento para quem delas participa ou assiste. As Folias de Reis possuem uma característica peculiar: celebrar a vida. 
Este caráter de esperança é que as transforma em uma manifestação vinculada às camadas subalternas da população.

Outrora manifestação rural, hoje é encontrada em vários centros urbanos. Esse deslocamento do espaço rural para o urbano pode ser um dos motivos da inclusão de novos elementos, próprios da modernidade, que foram incorporados em sua realização. As Folias contemplam as realidades da cultura subalterna que resistem e persistem em preservar suas ligações com as tradições, com seus valores e com a força vital que as nutre. Nelas, o mítico se funde com místico, e a vida, o cotidiano, a aspereza do diaa-dia ganha alento e esperança.

Segundo Pierre Bruñel (1998), o sentido místico e principalmente mítico das Folias de Reis remete para a tripla função que exercem: o de contar, o de explicar e o de revelar. Conta uma narrativa de um começo, uma narrativa de acontecimento fantástico - o nascimento de Cristo; explica uma origem - a origem divina de Cristo; e revela um dado sagrado - a presença de Deus entre os homens para anunciar a salvação da humanidade. Nas Folias são revividas as esperanças de um novo mundo, um mundo melhor.

Esse sentido messiânico foi amplamente acolhido nas grandes festas e folias barrocas; nelas, era dado o direito à grande massa de mestiços, negros e aos povos originários de participar junto com 0 fausto das irmandades, o aparato de poder dos militares e a onipotência da Igreja.

A identificação do povo com esses elementos de messianismo e esperança das Festas de Reis do Brasil Colônia transferiu para as características etnográficas dos três reis a conformação dos oprimidos da época e da atualidade. Em muitos relatos os reis são cantados e descritos 
como sendo: um preto, um caboclo e, outro, mulato. Também são apresentados em número de quatro: branco, o português; negro, o africano; o mestiço e o quarto, o "índio", que desapareceu. Essa versão "à brasileira" do número dos reis ainda é contada por foliões da região de Ourinhos: "Eram quatro Reis, mas o quarto não acreditou e seguiu outro caminho, não encontrou o Menino, andou, andou e veio parar aqui e daí nasceu os "índios" e é por isso que eles sumiram", depoimento de folião de Nova Fátima/PR (2008), no encontro de Folias de Assis/SP; ou, como relata também outro folião de Palmital/SP (2008): "tinha um quarto que seguiu por outro caminho, sozinho, e não chegou em Belém, ele ficou procurando a vida toda, ele era o mais rico, tinha um diamante muito grande, ele ficou andando e procurando e só encontrou Jesus na Cruz".

Outras versões cantam e contam que foi o rei negro Baltazar quem primeiro encontrou Jesus, após ter sido abandonado enquanto dormia pelos companheiros; sozinho e perdido, a estrela apareceu e o guiou primeiro e salvo até o Menino Deus.

O caráter de acolhimento e resistência explícito nessas narrativas aponta para a identificação e transferência das situações vividas pelos povos negros, escravizados e oprimidos para os personagens da narrativa bíblica ou de criar uma situação que explicitasse suas condições de vida. Desse modo, paralelo às celebrações romanizadas da Epifania, o povo criou suas próprias narrativas para atender aos seus anseios, encontrando maneiras de unir e religar o sagrado as suas tradições e vivências profanas.

Homens, mulheres, e crianças, em largo regozijo a liberdade de um dia, esqueciam por instantes as palmeiras de sua terra, os fetiches de seu país, aguardando a cerimônia da coroação do soberano, e rendendo culto ao santo Rei Baltasar, que Ihes recordava, pela cor 
que tinha, a cor de sua pele e de seu destino. (MORAES FILHO, 1979, p. 226).

É ainda de se notar que o número de reis não subdivide os pedidos e orações; as súplicas e agradecimentos são destinados aos Santos Reis, como sendo uma única entidade.

Por isso, frente à influência das constantes mudanças provocadas pelas inovações da contemporaneidade e pela globalização, as festas e tradições de Reis se conservam. Elas constituem o ethos de identidade de muitas comunidades, possuem a função de agregar e dar sentido aos grupos das culturas subalternas que permanecem apartadas dos sistemas hegemônicos. Desta maneira, o povo sabe, mesmo que às vezes inconscientemente, que preservar suas festas é uma forma de resistir. As manifestações populares são a continuidade da própria comunidade, a continuidade da vida espiritual e, conseqüentemente, das relações sociais. Participar das festas da sua comunidade é se ver no espelho e reconhecer a sua identidade cultural, é pertencer e encontrar o outro e se ver nele.

O giro das folias pelas casas é um forte fator de agregação e pertencimento que as transformam em uma das festas com maior incidência no interior das regiões citadas, assim como uma das manifestações mais encontradas nos meios urbanos, principalmente vinculadas às comunidades de vilas e da periferia. Essa peregrinação pelos lares das comunidades transforma o espaço do cotidiano em um espaço sagrado durante o giro, como num cortejo, numa procissão, e as procissões conduzem seus participantes até o sagrado. Assim, acompanhar a folia é caminhar no sagrado e para o sagrado e visitar juntamente com ela as casas de seus conhecidos e iguais, que se transformam em uma "Belém". 
A visita de casa em casa realizada pelas Folias corresponde à caminhada e peregrinação que os reis fizeram para encontrar o Menino Deus. Chegar à casa do folião é desencadear o encontro dos Reis com o sagrado, conseqüentemente, quem recebe a Folia, está transformando sua residência no espaço sagrado do nascimento de Deus. São esses encontros que fazem da Folia uma festa impregnada de gratidão e esperança. A casa que recebe a bandeira é, desta forma, abençoada, juntamente com seus familiares.

A transformação do espaço profano em espaço sagrado dá à Folia uma autonomia em relação à Igreja romanizada e permite que cada grupo elabore seus rituais litúrgicos e de organização, mesmo sendo alguns foliões membros ativos da Igreja Católica (BRANDÃO, 1985). Em muitas festas os padres e até os bispos participam como convidados, podem rezar a missa ou o terço, mas não são os condutores do ritual.

As folias se originam entre familiares e grupos de amigos, mantidas principalmente através da oralidade, dentro do próprio grupo de origem. É comum a participação de todos os membros de uma família, adultos, velhos e crianças: o conhecimento é passado pela observação e pela participação. Esta centralidade das folias entre os membros de uma família mantém o conceito de patriarcado; normalmente, sempre é o membro mais velho do grupo que comanda e detém os saberes, dos ritos, das festas e do giro das folias.

No interior do estado de São Paulo, era comum a peregrinação nos chamados bairros rurais. Na cidade de Ourinhos, a Folia ainda está vinculada ao bairro rural de Ribeirão Grande. Hoje, em decorrência do êxodo 
rural, muitos membros desses bairros migraram para a cidade em busca de melhores condições de trabalho e vida.

Durante a pesquisa realizada no estudo de campo e nas bibliografias consultadas, foram encontrados vários relatos que correspondem à dinâmica da folia de Ribeirão. O deslocamento do grupo rural para o urbano não alterou a fé em Santos Reis e a realização da Folia passou a ser um momento de retorno e encontro dos membros originários dessas comunidades em busca de suas raízes e identidade, como também o de buscar na celebração dos Reis, força e proteção para o ano que será vivido e trabalhado nos meios urbanos. A realização de uma Festa de Reis envolve toda uma comunidade em atitudes solidárias, como compartilhar o que lhe é excedente, seja em gêneros alimentícios ou em dinheiro, bem como a participação de todos nos mutirões de organização das festas e do preparo dos alimentos.

Mas essa dinâmica de dispersão rural desencadeou várias modificações nos rituais de realização das folias, como: o giro, antes restrito ao ciclo dos doze dias, hoje, em muitas comunidades, acontece somente nos fins de semana e, para atender à solicitação de visitação em todas as casas das comunidades rurais, bem como das casas dos membros que residem nas cidades, muitas vezes em diferentes bairros, o período da visitação foi aumentado. Também, o que se fazia a pé ou a cavalo, hoje é feito de ônibus fretados (muitas vezes cedidos pelos poderes públicos; é muito comum o uso dos ônibus que fazem o transporte escolar rural) ou carros.

O almoço da festa é preparado com mais antecedência. $\mathrm{Na}$ festa de Palmital/SP, as carnes que serão servidas são compradas em frigorífico, e a estrutura de organização da festa passou a ter apoio da 
prefeitura e do estado. O controle e inspeção sanitária são feitos pelas autoridades locais. Essas são algumas das modificações detectadas nas festas da atualidade. 


\section{ORGANIZAÇÃO E ELEMENTOS DAS FOLIAS DE REIS}

\subsection{Atribuições e Funções dos Participantes das Folias de Reis}

Nas Companhias de Reis pesquisadas na região de

Ourinhos/SP foi verificada a existência de uma hierarquia e de respeito às atribuições dos foliões, bem como o profundo conhecimento do papel que cada um desempenha. Este saber é transmitido de modo informal, mas respeitando o papel e os conhecimentos que cada membro possui e desempenha.

Essa dinâmica possibilita a agregação dos diferentes elementos da comunidade, desenvolvendo um processo comunicativo de transmissão de saberes, processo que pode ser entendido como um dos elementos que colaboram para a manutenção das tradições e sabenças das Folias.

Esse conhecimento propicia a integração das Companhias com a sua espacialidade e também com outros mecanismos de comunicação da contemporaneidade, assim como com diferentes estratos sociais de onde se originam as Companhias.

Deste modo, foi observado que, na região, quase todas as Folias de Reis possuem as mesmas estruturas e mantêm uma coerência em suas funções: Embaixador, Gerente, Festeiro, Alferes, Músicos, Palhaços e Foliões. 


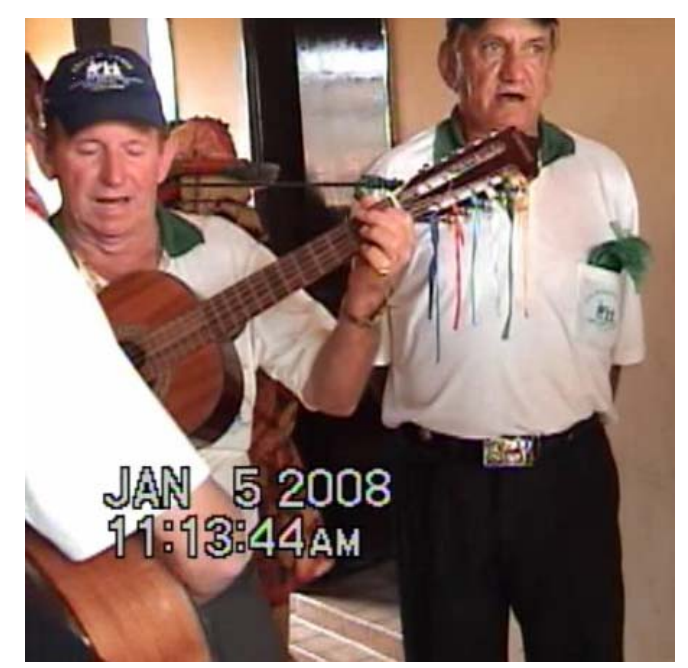

Foto 4.1: Embaixador tocando viola. Companhia dos Faceiros ${ }^{53}$

O Embaixador é o Folião que lidera o grupo nas cantorias, é o que "faz embaixadas (verso de improviso)" (GARBOSI, 2002). É ele quem faz a primeira voz, conhece os cânticos e ritos e é uma espécie de guardião da memória da folia.

Ser Embaixador é deter muita responsabilidade perante os companheiros; ele tira a cantoria de memória, normalmente não utiliza nenhuma referência escrita. Age como um repentista, improvisando as músicas de acordo com a organização e ambientação do espaço: como está a entrada da casa, como o altar está montado, se tem a presença de outros santos de devoção da família, fotos de antepassados e a disposição do presépio quando se faz presente. Faz a primeira voz e os Foliões repetem os versos na $2^{a}, 3^{a}$, $4^{a}, 5^{a}, 6^{a}$ e até na $7^{a}$ voz, em algumas folias.

Durante a apresentação, o embaixador se coloca de frente para outro folião, o da $2^{a}$ voz, que comanda a resposta do canto. Estes dois cantores principais são acompanhados por instrumentos tocados por todo o

\footnotetext{
${ }^{53}$ Giro da Folia da Companhia dos Faceiros, da cidade de Palmital/SP. Embaixador fazendo improviso com viola. Foto da autora, Janeiro de 2008.
} 
grupo. Os outros Foliões, perfilados atrás dos primeiros, concluem os versos emitindo as últimas palavras e a última voz emite um longo e prolongado grito.

O Embaixador se coloca na posição de quem prega o evangelho, os princípios da folia e a crença nos Santos Reis; é o mediador entre os participantes e o sagrado.

Quando a Folia é recebida por devoção, a apresentação tem uma conformação: é breve, o grupo canta abençoando a família, solicita a oferta para a festa e sai. Quando a visita é solicitada como paga de promessa, o Embaixador se informa do teor da graça alcançada e a explicita cantando para o grupo. Nestes casos, o Embaixador faz o papel de intercessor com o sagrado: é através de sua cantoria que os Reis são comunicados dos pedidos e da graças alcançadas. O bom Embaixador tem que ter habilidades e uma capacidade de perceber os anseios dos devotos e explicitar esses desejos através de seus versos. Ser Embaixador é ser um repentista do sagrado.

Ele deve conhecer bem o propósito da Folia, sua história e o Evangelho; alguns Embaixadores pesquisados afirmam que só depois de se sentirem seguros quanto a esses conhecimentos é que aceitaram essa função. O Embaixador também é conhecido em algumas Folias como Mestre ou Maestro.

\author{
Esse é o primeiro verso \\ Que eu canto nesse dia \\ Esse é o primeiro verso \\ $\mathrm{Ai}$, que eu canto nesse dia, ai,ai \\ Viajando \\ Os foliões e companhia \\ Viajando \\ Ai, os foliões e companhia, ai,ai \\ Nóis vem vindo de tão longe \\ Visitar sua família \\ Nóis vem vindo de tão longe \\ Ai, visitar sua família, ai,ai \\ Por favor, acende a vela \\ Pra clareá o cantar \\ Por favor, acende a vela
}


Pra clareá nóis a cantar, ai,ai Vamos cantar uma música E falar do nascimento Vamos cantar uma música $\mathrm{Ai}$, e falar o nascimento, ai,ai $E$ o Menino foi nascido Do mais puro coração O Menino foi nascido Ai, do mais puro coração, ai,ai O menino foi nascido De uma Bela Criatura O Menino foi nascido Ai, de uma Bela Criatura, ai,ai Os profetas escreveu, ai, $O$ que está nas escrituras Os profetas escreveu $\mathrm{Ai}$, o que tá nas escrituras, ai, ai O senhor me dá licença A cantoria vai parar O senhor me dá licença A cantoria vai pará, ai, ai, eh... (Improviso do Embaixador, Companhia dos Faceiros, 2008) $)^{54}$

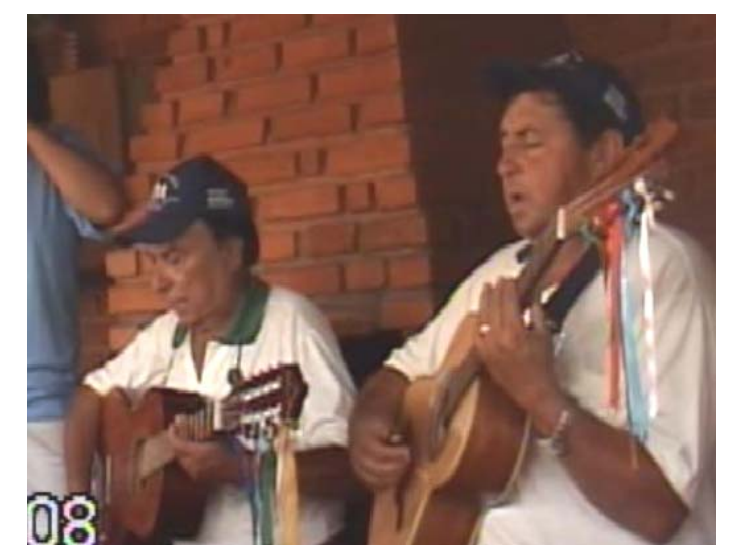

Foto 4.2: Gerente da Companhia dos Faceiros, à esquerda na foto ${ }^{55}$

O Gerente é normalmente uma pessoa que possui e exerce liderança junto aos Foliões e na comunidade; é dele a responsabilidade de conduzir o grupo e estabelecer as normas e regras da Folia; quando necessário, repreende a todos ou algum Folião. Responsável pela condução do terço, sempre carrega um terço ou rosário, faz a leitura da Bíblia quando solicitado e sugere o teor das cantorias nos lugares visitados. Controla os

\footnotetext{
54 Transcrição de improviso do embaixador da Cia dos Faceiros, realizada em janeiro de 2008 pela autora.

${ }^{55}$ Giro da Folia da Cia dos Faceiros, da cidade de Palmital/SP. Foto da autora, Janeiro de 2008.
} 
horários, o percurso, dá os avisos, entra em contato com as outras lideranças da comunidade. É o responsável pelo início e fim dos giros e da festa, conduz a passagem da coroa para o novo festeiro.

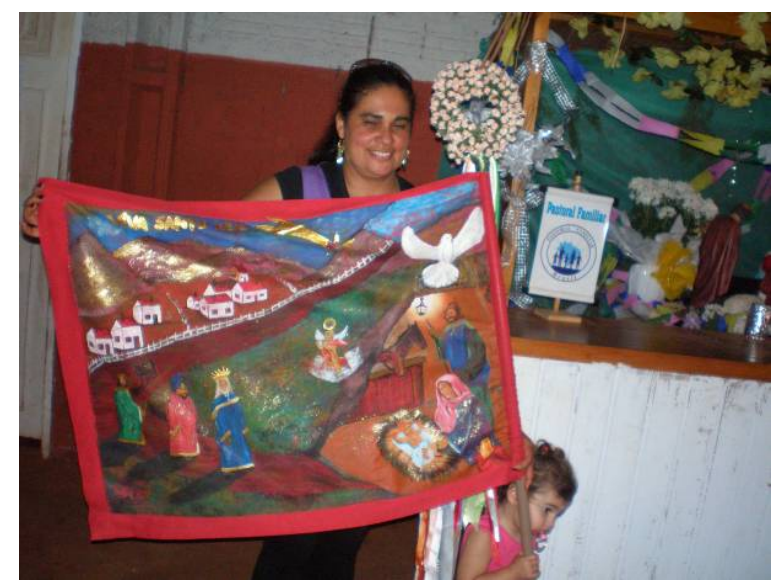

Foto 4.3: Festeira para 2009 de Ourinhos/SP ${ }^{56}$

O Festeiro é o organizador da festa. Normalmente, é de sua residência que o encontro dos Foliões, a reza do terço e o almoço de saída acontecem, dando início ao giro da Folia. Ele e sua família também são responsáveis pela ornamentação da bandeira e da retirada das fitas, pedidos e outros objetos colocados na bandeira, no giro anterior. Esse ritual possui variações, mas é comum acontecer na casa do Festeiro do ano. A festa da chegada é realizada sob seu comando e normalmente em sua casa; é dele a obrigação de organizar e preparar a comida servida no dia da festa, bem como cuidar do ritual de passagem da coroa para o próximo Festeiro; por isso, em algumas festas, é chamado de "Imperador". Também a preparação do espaço onde será realizada a festa é de sua competência. O local onde a Festa de Reis de Ourinhos/SP é realizada foi construído por antigos Festeiros e permanece, até hoje, no bairro rural de Ribeirão Grande.

\footnotetext{
${ }^{56}$ Festeira de 2009, da Folia do bairro de Ribeirão Grande, Ourinhos/SP. Foto da autora, Julho de 2008.
} 




Foto 4.4:

Galpão onde é realizada a Festa de Reis, no bairro de Ribeirão Grande, Ourinhos/SP ${ }^{57}$

Ser Festeiro é assumir uma grande responsabilidade; geralmente é manifestada por devoção, paga de promessa a Santos Reis ou para manter a tradição, como foi observado na Festa de Reis deste ano em Ourinhos: "aceitei para não deixar perder a tradição da família; na hora senti que tinha que assumir a Festa, lembrei do meu pai e de Santos Reis e aceitei" - depoimento dos Festeiros que irão realizar a Festa em 2009, em Ourinhos.

Em algumas comunidades o Festeiro é escolhido entre os membros de maior poder aquisitivo, destaque político, ou que exerçam lideranças e articulações com a comunidade; mas pode ser um Festeiro que peça para assumir essa função para pagar promessas ou outras intenções e, quando não pode arcar com os custos dos preparativos da Festa, a comunidade colabora para que a intenção do solicitante se cumpra.

\footnotetext{
${ }^{57}$ Foto da Autora, julho de 2008.
} 
O festeiro de Palmital/SP em 2008 declarou que, para dar início aos preparativos da Festa, foram desembolsados, aproximadamente, cinqüenta mil reais. Esse valor lhe seria ressarcido após o leilão do gado doado e da venda da bebida no dia da Festa. Os Festeiros de Ourinhos, para 2009, também comentaram que já iriam se preparar para desembolsar uma quantia para dar início à Festa, e que são os leilões dos animais doados, juntamente com as bebidas, que cobrem essas despesas.

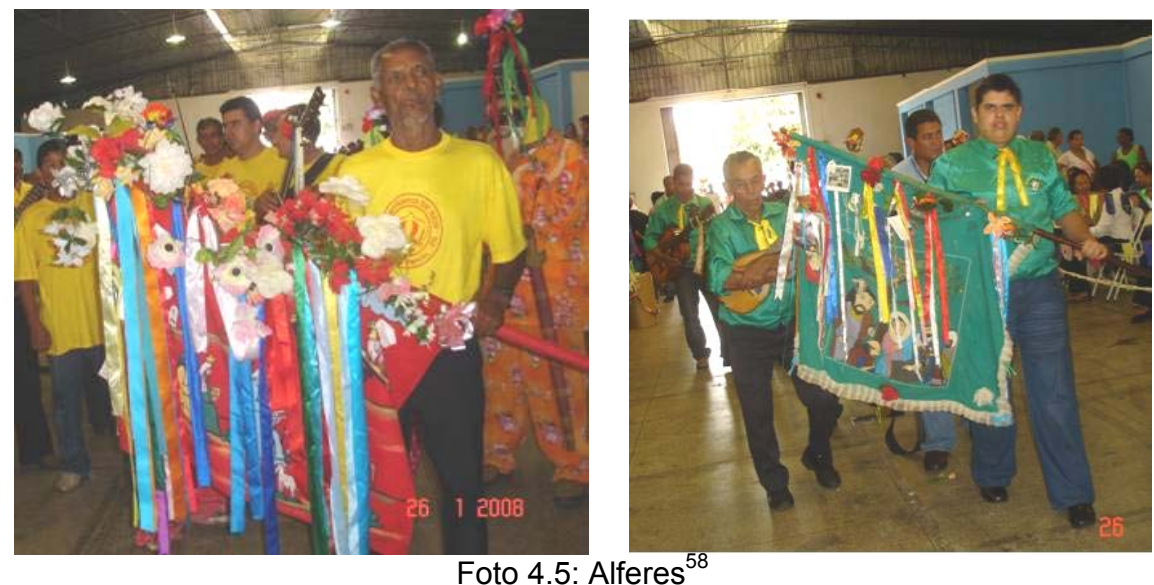

O Alferes fica à frente do grupo, segurando a bandeira. Em algumas comunidades, essa função é delegada para membros mais velhos; mas pode ser para outras pessoas que estão pagando promessas. Na maioria das Festas pesquisadas, era um membro do grupo e, muitas vezes, essa função é revezada entre eles durante o terço ou o giro. Normalmente se colocam nessa função com muito respeito, procuram seguir as normas e tradições do grupo. Nas Folias, o Alferes está sempre em destaque, pois a bandeira é o elemento que carrega o sagrado: todo o ritual dos giros, dos almoços, pousos, terços nos presépios é centrado nela.

\footnotetext{
${ }^{58}$ Alferes no Encontro de Folias de Reis na cidade de Assis/SP. Foto da autora, Janeiro de 2008.
} 
O Alferes também recebe as prendas e ofertas e informa para o Embaixador elou para o Gerente sobre o que foi recebido. Em algumas companhias existe um Folião que assume a função de registrar em um caderno tudo o que foi doado e, no dia da Festa, é apresentado um balanço das doações, fixado em cartaz ou lista para toda a comunidade - é a prestação de contas. Nesses casos, o Alferes assume o papel de supervisionar as ofertas doadas. Esta supervisão dá credibilidade à Folia.

Em algumas companhias as doações excedentes são doadas para instituições de caridade, como asilos e orfanatos. Outras transformam o excedente em cestas básicas, que são doadas a famílias carentes. Em todos os depoimentos recolhidos, evidenciou-se que tanto a companhia quanto os Festeiros não obtêm lucro ou fazem uso das prendas arrecadadas. Essa postura de desprendimento é um fator de orgulho de para muitas companhias.

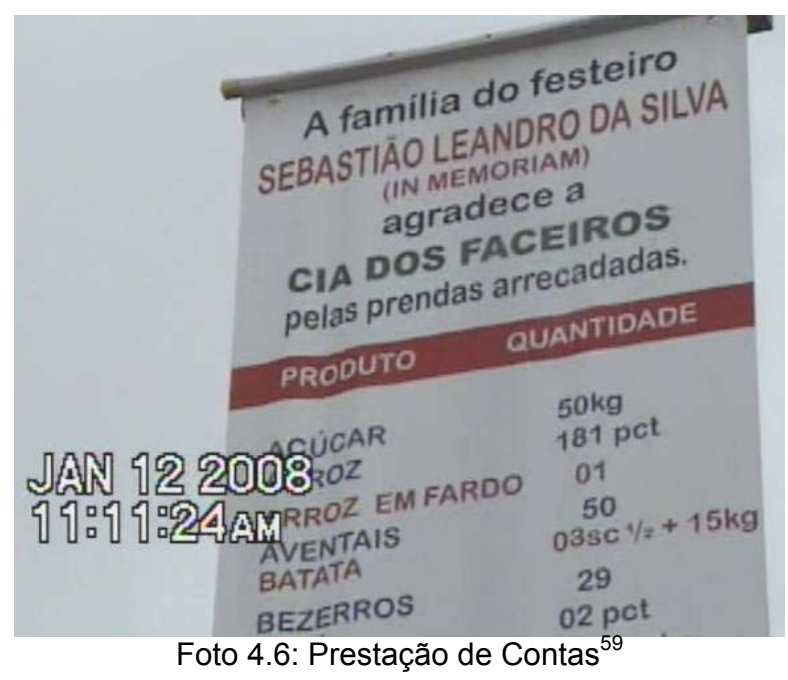

\footnotetext{
${ }^{59}$ Banner com prestação de contas das prendas arrecadadas na Festa de Folia de Reis na cidade de Palmital/SP. Foto da autora, Janeiro de 2008.
} 


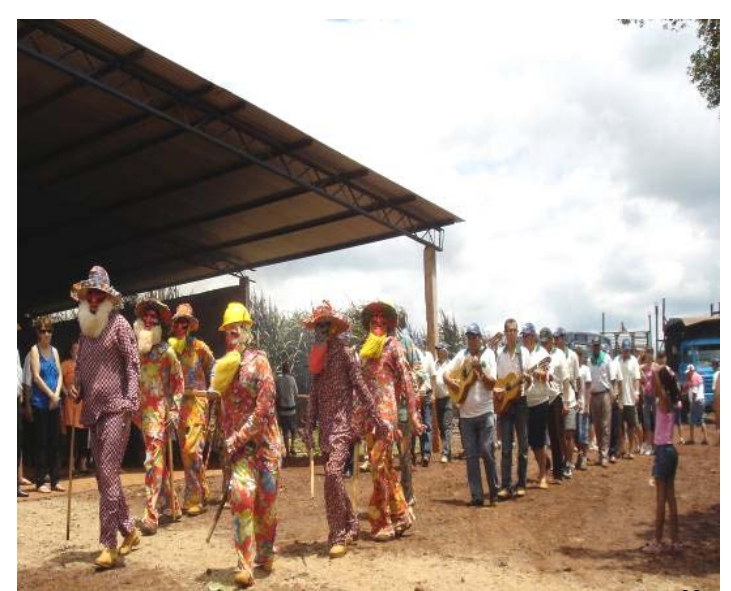

Foto 4.7: Músicos da Companhia dos Faceiros ${ }^{60}$

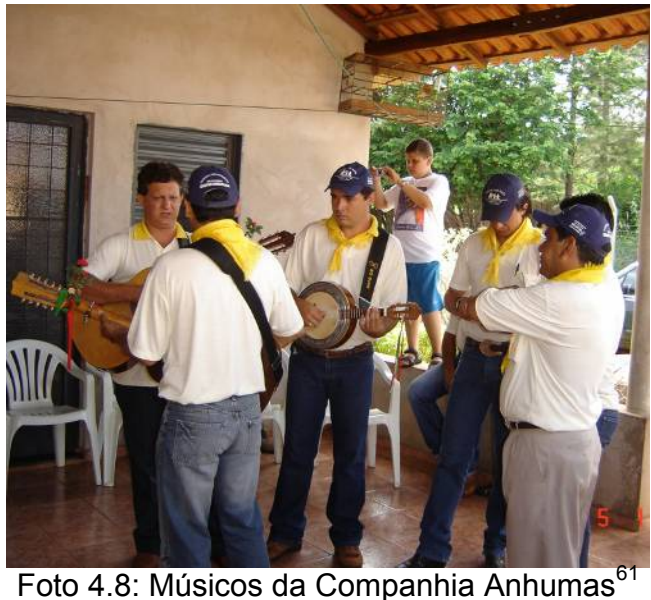

Foto 4.8: Músicos da Companhia Anhumas

Os Músicos são a base dos rituais das Folias. Praticamente todos os integrantes de uma companhia tocam algum instrumento e também são cantores. Os rituais das Folias, em sua totalidade, são feitos em forma de versos e cantados, como um "repente", e repetidos por todos do grupo, principalmente as súplicas e agradecimentos. O Embaixador improvisa os versos que são repetidos pela segunda voz e finalizados pelos componentes da Folia. Normalmente, o Alferes e os Palhaços não participam das cantorias.

A forma como são organizadas as cantorias ou toadas sofre pequenas variações de grupo para grupo ou de região, mas a base é quase sempre a mesma, sete vozes, sendo a primeira do Embaixador, que elabora os versos, a segunda e terceira repetem o verso inteiro duas ou três notas acima da primeira e as outras somente as últimas palavras ou metade do verso, cantando de quatro a seis vezes acima da primeira e a sétima ou oitava voz emite um grito agudo e longo, muitas vezes somente a última vogal do verso ou a rima do final do verso.

Garbosi (2002, p.50) esclarece como são em sua companhia compostos os músicos:

\footnotetext{
${ }^{60}$ Entrada de músicos da Cia. dos Faceiros em Palmital/SP. Foto da autora, Janeiro de 2008.

${ }^{61}$ Músicos da Cia. Anhumas de Palmital/SP. Foto da autora, Janeiro de 2008.
} 
Não existe um número específico, geralmente uma Folia de Reis é composta de 12 foliões: embaixador (base) mestre, capitão ou tiradô de Reis. Nome correto embaixador, porque faz embaixadas (verso de improviso), contramestre (dueto), contralto (tenor) também chamado de contrato. [...] tiple (soprano), contratiple (quinteto), tala (sexteto), talinha (sétima).

Também os instrumentos usados nas Folias têm significados e são tidos como sagrados. Garbosi (2002, p.102) conta que a viola de dez cordas ou caipira era tocada e usada por São Gonçalo para fazer curas e milagres. O depoimento do embaixador da Companhia dos Faceiros de Palmital/SP (2008) confirma essa organização dos Músicos na cantoria: "sou embaixador, depois o contra mestre é quem ajuda, o contrato é o esteio da cantoria, depois é o tala, contra talo, tipo e contratipe que é o último, são seis ou sete vozes, tipo é o último." ${ }^{22}$

As músicas vinculadas às Folias de Reis são comumente estruturadas em formas de quadras - estrofes com quatro versos - sempre cantadas e acompanhadas de instrumentos como: viola, violão, rabeca, caixa, bumbo, pandeiro, reco-reco, chocalhos, banjo, zabumba, triângulo, pandeiro, maracas, sanfona, cavaquinho e flauta de taquara; em algumas companhias; flautas ou outro instrumento de sopro. Foram mantidas na tradição, através das gerações, pela oralidade e pelo aprendizado informal dos instrumentos. As toadas representam a alma das Folias, nelas os sentimentos dos Foliões e a fé são expressos.

A cabeça do mestre é como um computador. Fazemos de improviso.
É só dá a viola na minha mão que daí eu já começo a fazer
improvisado, nada é escrito, tudo improvisado. E não tá gravado.
Não tem como escrever, porque a gente não sabe quais são as
ofertas ou as prendas, não tem como decorar porque cada pessoa
que oferece uma prenda faz um tipo diferente de pedido. Cada pedido
tem um tipo de mensagem pra rimá, a gente trabalha em cima da
rima. (Depoimento de Embaixador, 2008). ${ }^{63}$

62 Depoimentos do Embaixador da Companhia dos Faceiros, da cidade de Palmital/SP sobre a organização dos músicos. Coletado pela autora, em janeiro de 2008.

${ }_{63}$ Depoimentos do Embaixador da Companhia dos Faceiros, da cidade de Palmital/SP sobre o improviso das músicas. Coletado pela autora, em janeiro de 2008. 


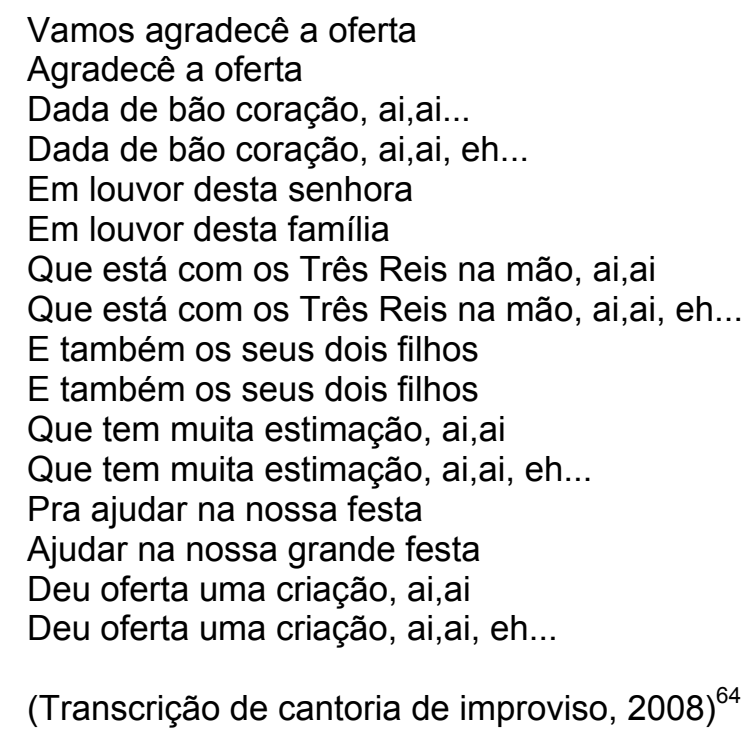

As toadas das Folias de Reis são tão peculiares que são reconhecidas independentemente do local onde estão sendo executadas. Nelas predomina uma unidade musical que as caracteriza em todo o país; mas, são as do sudeste que possuem maior similaridade. As cantadas na região de Ourinhos são muito parecidas com as do sul de Minas.

$\mathrm{Na}$ atualidade, também estão sendo pesquisadas e utilizadas como forma de imprimir características de brasilidade à Música Popular Brasileira (MPB). Milton Nascimento gravou Calix Bento, também repertório de Pena Branca e Chavantinho. Muitos compositores da atualidade também podem ser citados como conhecedores das Folias de Reis e fizeram uso desse conhecimento em suas produções. Dentre eles, pode-se citar Martinho da Vila, Tim Maia, Fagner e Zeca Baleiro.

\author{
Hoje é o dia do Santo Reis \\ Anda meio esquecido \\ Mas é o dia da festa do Santo Reis \\ Hoje é o dia do Santo Reis \\ Anda meio esquecido \\ Mas é o dia da festa do Santo Reis \\ Eles chegam tocando sanfona e violão \\ Os pandeiros de fita carregam sempre na mão
}

\footnotetext{
64 Transcrição de gravação do improviso do Embaixador da Companhia dos Faceiros, da cidade de Palmital/SP. Coletado pela autora, em janeiro de 2008.
} 
Eles vão levando, levando o que pode

Se deixar com eles, eles levam até os bode

É os bode da gente, é os bode mééé...

É os bode da gente, é os bode mééé...

Hoje é o dia do Santo Reis (hum...)

Hoje é o dia do Santo Reis (Hoje é o dia)

Hoje é o dia do Santo Reis (É o dia da festa)

(A Festa de Santo Reis, Tim Maia) ${ }^{65}$

Meu senhor, dono da casa

llumine este salão

Trago um canto diferente

Cá dentro do coração

Se é grande o firmamento

É maior a solidão

Lá na terra de ninguém

Aprendi esta canção

Lá na terra de ninguém

Aprendi esta canção

Cante com este canto quando ouvir cantar

Chore com meu choro por ouvir falar

Que atrás da serra, muito mais pra lá

Vive um povo triste que sabe cantar

Que canta a noite inteira até o sol raiar

Falam de um reino que há de vingar

Fosse para um dia a vida melhorar

Cantaria a noite inteira sem parar

Fosse para um dia a vida melhorar

Cantaria a noite inteira sem parar

Fosse para um dia a vida melhorar

Cantaria a noite inteira sem parar

Fosse para um dia a vida melhorar

(Reizado, Fagner) $^{66}$

[...]

tá todo mundo querendo rir para o mundo

fingindo falar umbundo

para impressionar inglês

fui numa rave

nos confins de Arapiraca

enfiei o pé na jaca

cantei folia de reis

- senhora dona da casa

vim cantar mais uma vez

deus the dê felicidade

paz amor e ...

[...]

(Drumembêis, Zeca Baleiro) $^{67}$

\footnotetext{
${ }^{65}$ Letra da música Festa do Santo Reis, interpretada por Tim Maia, letra de Marcio Leonardo recolhida na internet. Disponível em: <http://vagalume.uol.com.br/tim-maia/a-festa-de-santo-reis.html>. Acesso em: 30 de outubro de 2008.

66 Letra da música Reizado, do cantor Fagner, recolhida na internet. Disponível em: <http://vagalume.uol.com.br/fagner/reizado.html>. Acesso em 30 de outubro de 2008.
} 


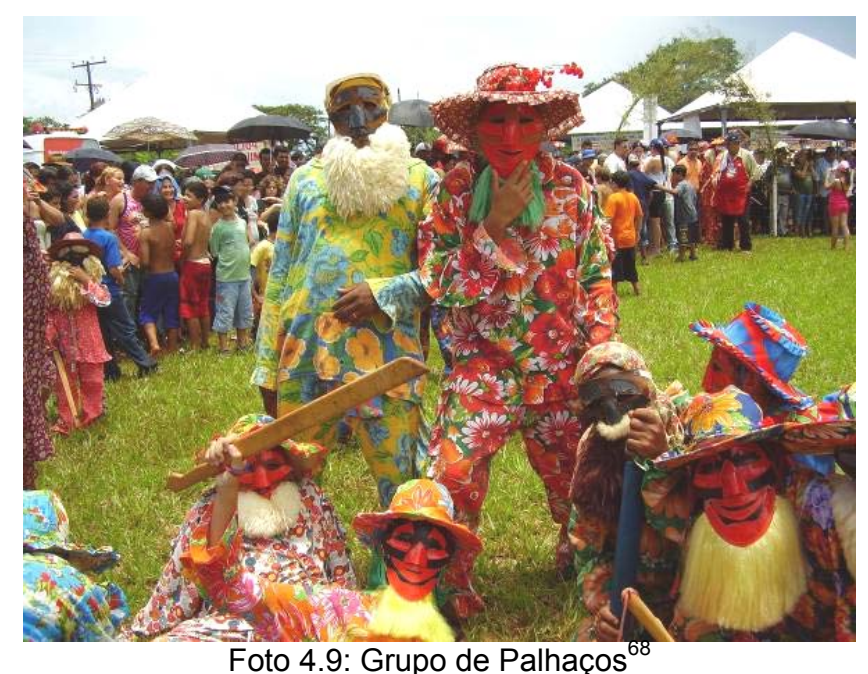

O Palhaço ou Bastião possui dupla interpretação e caráter dúbio. Em algumas Folias, ele representa os soldados de Herodes, o mal, o diabólico; em outras, representa aqueles que foram convertidos e preservaram a vida do Menino Jesus ou os pastores que se vestiram de palhaços para divertir os soldados e atrapalhar, dando tempo do Menino fugir da perseguição de Herodes.

É um personagem misterioso, alegre, cínico e dissimulado, sempre usa máscara. Quando representam os soldados, suas roupas simbolizam: a veste colorida e florida a farda, o chapéu o capacete e o bastão a espada.

Os Palhaços nunca andam na frente da bandeira; acreditam que, por simbolizarem os soldados que perseguiram Jesus a mando de Herodes e nunca o encontraram ou capturaram, devem andar sempre atrás da bandeira.

\footnotetext{
67 Letra da música Drumembêis, de Zeca Baleiro, recolhida na internet. Disponível em: $<$ http://vagalume.uol.com.br/zeca-baleiro/drumembeis.html>. Acesso em: 30 de outubro de 2008. ${ }^{68}$ Palhaços da Cia. dos Faceiros na festa de Palmital. Foto da autora, Janeiro de 2008.
} 
Quando na presença do presépio, tiram suas máscaras, chapéus ou capacetes e ficam sempre de joelhos. No fim dos cerimoniais, quando solicitado e, na presença de presépios, pedem perdão ao Menino Deus. Neste momento, a crença é de que estão pedindo perdão pelas falhas e pecados dos participantes das Folias e espiando as culpas da própria comunidade.

Em algumas Folias, é deles a função de recitar e não cantar versos em frente ao presépio sobre as profecias e o nascimento do Menino. Nas Festas pesquisadas, é um momento de muita emoção e respeito para com o Folião e/ou Palhaço, que sabe todos os versos de memória. Às vezes também improvisa versos para a família ou antepassados do grupo.

Cabe aos Palhaços, também, divertir o grupo; as crianças sempre os acompanham e muitas esperam as Folias principalmente pela sua presença; sua comicidade atrai os pequenos. Em algumas Folias, é permitida a presença de meninas nesta função e de crianças fantasiadas.

Sua figura faz a transição entre o sagrado e o profano nas cerimônias, entre o caráter solene e o lúdico das Festas. Os Palhaços usam máscaras confeccionadas com diferentes materiais, sempre muito coloridas, às vezes, com expressões aterradoras, outras cômicas; sabem dançar, executar acrobacias e promover brincadeiras. Para alguns as máscaras dos Palhaços atraem os pensamentos negativos e protegem os componentes do grupo durante o giro. Em algumas companhias sua presença não é aceita. Alegam que distraem a atenção do sentido religioso das visitas, ou que sua figura denigre a imagem do grupo perante o povo e ou a Igreja romanizada. 


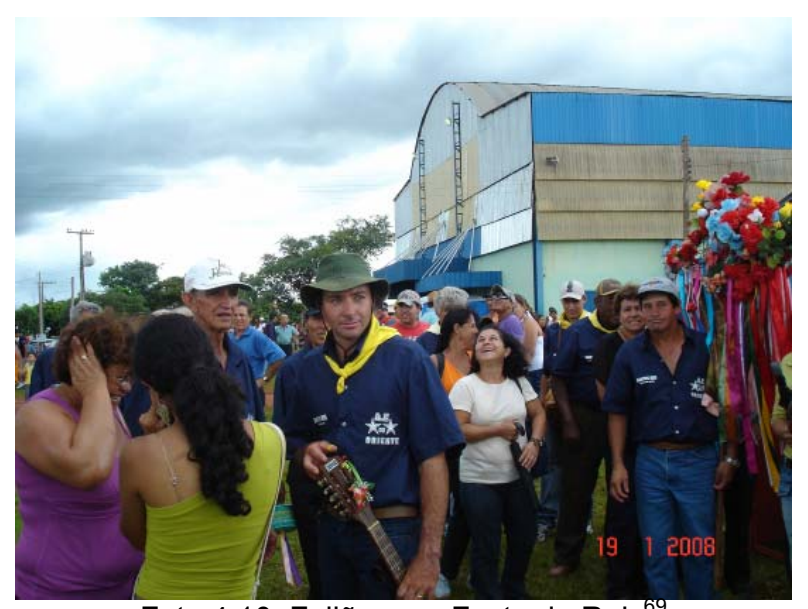

Foto 4.10: Foliões em Festa de Reis ${ }^{69}$

O Folião é todo participante que acompanha a peregrinação da Folia de Reis, desde o Gerente ao Embaixador. Em alguns grupos, três membros usam uma fantasia de Reis, e os demais são reconhecidos pelo uniforme que usam. Quando não usam uniformes, usam uma camiseta com o nome da Companhia, um lenço, boné, fita no pescoço, colete ou distintivo para se diferenciarem dos demais espectadores; também os Palhaços ou "Bastiões", são Foliões. Quando um Folião exerce a função de Mestre de cerimônia, seu uniforme poder ser acrescido de mais elementos que o distingue do grupo. As crianças quando acompanham seus pais ou parentes também usam uniformes.

Normalmente os Foliões sabem tocar um instrumento musical usado na Folia; são quase sempre cumpridores de promessas feitas aos Reis e, portanto, saem no giro por sete anos e muitos continuam a participar mesmo após o cumprimento desse prazo. Também são comuns Foliões que não exercem funções, apenas acompanham, rezam e auxiliam quando solicitado; outros declamam a passagem bíblica da natividade.

Foi com um poder divino que um anjo veio anunciar, Ave Maria cheia de graça, quer Jesus aceitá? Bendita sois Vós entre as mulheres, filha de Ana e Joaquim descendente de Noé, bendito é o fruto de vosso ventre

\footnotetext{
${ }^{69}$ Festa de Reis e Encontro de Folias em Ribeirão do Sul/SP. Foliões de Cândido Mota. Foto da autora, Janeiro de 2008.
} 
Jesus nascido da Virgem Maria, no reino de luz, em 25 de março ele foi concebido, 25 de dezembro Jesus Cristo é nascido, ajuntou milhares de anjo na hora do nascimento, mandado o Pai eterno, do Divino Sacramento.

O galo cantou, São José acordou, que nasceu em Belém o Salvador, e foi o boi para dar o seu calor, esquentar o Redentor. Isso era meia-noite quando os brotos se abria, alertando os animais que o Rei do mundo já nascia. Ajuntou os pastorzinhos quando a estrela aparecia e pegando aquele caminho foi ver o que acontecia. Os três Reis do Oriente, guiado pela estrela Santa da Guia, viajando noite e dia ao longo de terras percorria, de longe avistaram a velha estrebaria e chegando perto dela era Jesus quem nascia. O ranchinho era pequeno, não cabia todos os treis, foi entrando um a um, cada um por sua vez. Ao entregar seu presente, pro Menino ele dizia: de Judá, o Messias. Pra indescente de Herodes, que era o rei da covardia, passaram no mar sagrado pra fazer outra travessia, e voltando pro Oriente, e voltando no dia 6 de Janeiro, quando deu meio dia fizeram uma grande festa, foi chamado Epifania. E Jesus foi crescendo, explicando a profecia seu mandamento dizia é capaz de explicar pra quem não sabe adorar. Na folia dos Três Reis Santos ninguém pode ignorar. Viva o Jesus Menino! Viva! Viva a companhia dos Três Reis! Viva! (informação verbal). ${ }^{70}$

\subsection{Elementos Iconográficos das Folias}

Uma das características mais marcantes das festas populares são seus elementos iconográficos. Pela sua propriedade de linguagem imagética, é necessário dominar os códigos de sua constituição para se efetuar uma boa leitura. Sendo assim, são esses elementos que possibilitam ao visitante saber de que festa se trata: Congada, Cavalhada, Reisado, Festa do Divino, Festa de Nossa Senhora da Conceição, Festa de Reis.

Portanto, este conhecimento constitui um dos saberes primordiais para se compreender e reconhecer uma Companhia de Reis.

Nas festas pesquisadas a primeira leitura que se faz é de uma movimentada festa rural ou de periferia, mas após deter o olhar, é possível reconhecer seus elementos visuais constitutivos, como: a bandeira, o altar, a

\footnotetext{
${ }^{70}$ Verso de improviso de folião da Cia. dos Faceiros. Colhido pela autora, em janeiro de 2008.
} 
coroa (ou coroação), o mastro, os arcos, o presépio, os bastões dos palhaços, as diferentes cores, as máscaras e os uniformes e indumentárias dos foliões.

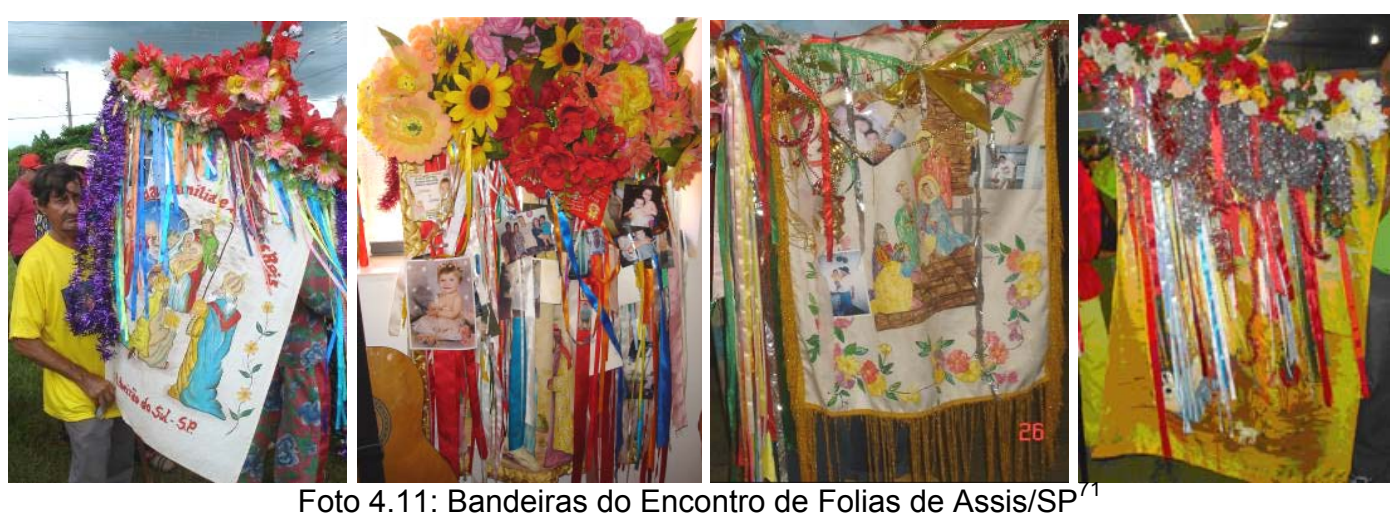

A bandeira estabelece a relação entre o sagrado e os devotos nas Folias: possui a aura da sacralidade; é também a materialização do sagrado, é o centro de todas as cerimônias e rituais.

Relatos históricos sobre as festas religiosas e, especialmente, as Folias de Reis, apontam para a presença da bandeira sempre à frente dos grupos e cortejos, bem como para a importância que os estandartes e as bandeiras já tinham nas diferentes culturas, principalmente nas tradições européias do medievo.

O propósito das Folias de Reis é levar a bandeira pelos diferentes lugares, não deixar de visitar as casas que solicitam sua presença e percorrer toda a sua jornada no bairro ou comunidade na qual está inserida, exatamente como os Santos Reis completaram a sua viajem até Belém.

Ela possui vários sentidos para os Foliões como: ser a estrela que guiou os Reis, ser os próprios Reis ou ainda o próprio Menino Deus. Há relatos de que, após a visita, os Reis ganharam como presente da Virgem

\footnotetext{
${ }^{71}$ Bandeiras de diversas Folias de Reis no encontro de Folias da cidade de Assis/SP. Foto da autora, Janeiro de 2008.
} 
Maria, o seu manto e, com ele, o pedido para que anunciassem o nascimento do Salvador. Por isso, a bandeira é elemento essencial da Folia, carrega o sentido e a sacralidade.

Normalmente as bandeiras são feitas de tecidos vistosos, onde é estampada ou bordada a figura dos Três Reis ou da Natividade, enfocando a visita dos Magos. Em algumas bandeiras, também está estampada uma pomba, que representa o Divino Espírito Santo, ou uma estrela com cauda, a Estrela Guia. Os foliões acreditam que a Pomba do Divino abre os caminhos durante o giro e que a Estrela é "a guia para os Foliões". São enfeitadas com flores, fitas, franjas e outros elementos decorativos, sempre com muito brilho são muito coloridas e alegres.

Como portadora do elemento sagrado, a Bandeira é muito reverenciada e está sempre em destaque nos giros e cerimônias. Nas Festas de Reis, mesmo havendo outras manifestações do sagrado, é a ela que é dirigida a atenção, os pedidos. Sempre tocada, beijada, reverenciada, é nela que são depositadas as súplicas e manifestações de agradecimento, como fitas, fotos, pequenos objetos, dinheiro, pedidos escritos. Normalmente o Alferes permite que esses objetos sejam fixados na bandeira.

Quando algumas companhias não concordam com o que é fixado na bandeira, o Festeiro, Gerente ou Embaixador retira e deposita os objetos em outros lugares considerados sagrados, como: cruzeiros, capelas, cruzes encontradas nos caminhos, ou os jogam em água corrente.

Também quando a bandeira está "muito carregada" de fitas, bilhetes e/ou fotos de pedidos ou agradecimentos, estes são jogados em água corrente em cerimônia restrita, geralmente com a presença dos membros mais 
velhos ou que detenham o respeito do grupo. Cerimônia que acontece antes ou depois da jornada anual, ou quando se faz necessário. São os Festeiros ou o Gerente do ano que normalmente ficam encarregados de providenciar essas cerimônias, assim como a ornamentação da bandeira.

Em algumas companhias, as bandeiras permanecem com o Gerente após a Festa; em outras, na casa do Festeiro eleito. Também são comuns as saídas das bandeiras para apresentações e encontros de bandeiras em cidades diferentes de sua origem ou para acompanhar procissões, terços e outras festas religiosas, sempre acompanhada pelo grupo de Foliões.

Quando em visita às residências, é comum levá-las pelos seus cômodos para que sejam abençoados e purificados. Nas pesquisas realizadas, foi encontrada uma bandeira com quase cem anos - ela está com a mesma família vinda de Minas Gerais.

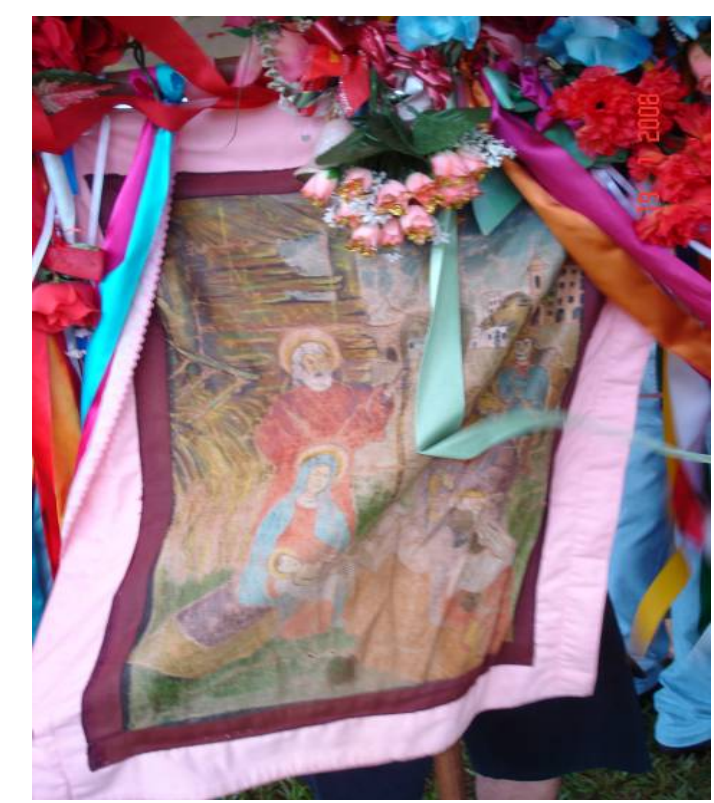

Foto 4.12: Bandeira centenária de Cândido Mota/SP ${ }^{72}$

\footnotetext{
${ }^{72}$ Foto da autora, Janeiro de 2008.
} 
Há também a crença de que a bandeira não pode permanecer guardada, deve ser passada todo ano para outra pessoa. Acredita-se que 0 não cumprimento dessa regra pode gerar muitas coisas ruins: doenças, pouca fartura, contratempos nos negócios, má colheita ou acontecimentos negativos com a família do festeiro, grupo de foliões e/ou comunidade.

No Brasil, o uso de bandeiras pelas irmandades religiosas é muito comum. Existem diferentes cerimônias em que as bandeiras são consideradas como elementos fundamentais. Elevar ou arriar bandeiras dos santos são cerimônias revestidas de muito significado; essas cerimônias e rituais também acontecem nas atividades cívicas que envolvem as bandeiras. Câmara Cascudo (2001, p.45,46) relata sobre a bandeira: "ter a bandeira era a oficialização da associação. Dizia-se então que era oficio embandeirado, reconhecido pelo rei. As bandeiras dos oragos proclamavam a autenticidade das homenagens aos seus méritos tradicionais." Ainda no mesmo texto, cita que Rossini Tavares de Lima diferencia bandeiras de estandartes: as bandeiras são fixadas em mastro pela extremidade superior e os estandartes pelo centro, por um cordão. E completa: "nas Irmandades predominam os estandartes".

Assim são as bandeiras que, pela mão de alguém, vão de casa em casa a recolher donativos para as festas do Divino, Reis, São João e outros santos. Há também bandeiras em molduras. É o que acontece em São Paulo: Santa Cruz, São João e o Divino. Estas são içadas em mastros. [...] $O$ povo é que não distingue bandeira de estandarte provindos de bandaria, banda, bando, grupo sob o mesmo símbolo, e extendere do ostentar, expor, o brasão do reino ou do senhor feudal. (CÂMARA CASCUDO, 2001: 46).

Outras abordagens são feitas em relação às bandeiras. Segundo Chevalier e Cheerbrant, ela pode representar proteção, concedida ou implorada. 
O portador de uma bandeira ou de um estandarte ergue-o para cima de sua cabeça. De certo modo, lança um apelo ao céu, cria um elo entre $o$ alto e o baixo, o celeste e o terreno. [...] no plano Cristão a bandeira simboliza a vitória do Cristo ressuscitado e glorioso. Toda proteção litúrgica, durante o tempo pascal e a ascensão, inclui o emprego de bandeiras.

Ao passarem do Cristo à alma, as bandeiras significam [...] a sublevação (sublevatio) (do verbo lat. Sublevare, em port. sublevar, no sentido de 'levantar de baixo para cima') e a elevação (elevatio) do espírito. [...] Estar suspenso acima da terra é ser iniciado nos segredos divinos.

Esse símbolo de proteção acrescenta-se ao valor do signo distintivo: bandeira de um senhor feudal, de um general, de um chefe de Estado, de um santo, de uma congregação, de uma corporação, de uma pátria etc. A bandeira oferece a proteção da pessoa, moral ou física, de quem ela é a insígnia. (CHEVALIER; CHEERBRANT,1997, p.118-119)

Partindo das considerações acima, nas Folias a bandeira é seu

principal elemento; é ela que dá sentido a todos os rituais. Também carrega

todo o sentido do "sagrado". Sem a bandeira as Folias de Reis não existiriam.

Nas cantorias registradas é comum versos destacarem esse

papel sagrado desempenhado por ela, como nos exemplos abaixo:

\author{
Despedida \\ Dê um beijo na bandeira \\ Que a hora já chegou \\ Dê um beijo na bandeira \\ $\mathrm{Ai}$, que a hora já chegou, ai, ai. eh... \\ Folião tá despedindo, ai, ai \\ Da senhora e do senhor \\ Folião tá despedindo \\ $\mathrm{Ai}$, da senhora e do senhor, ai, ai, eh...
}

\section{Solicitação de prendas}

Tenha fé nos Santos Reis, ai, ai

A Bandeira tem virtude

Tenha fé nos Santos Reis

Ai, a Bandeira tem virtude, ai,ai,eh...

Em louvor da juventude

Deus lhe dê muita saúde

Durante a sua vida

Deus lhe dê muita saúde

Ai, durante a sua vida, ai,ai,eh...

(Improviso de Embaixador da Companhia dos Faceiros, 2008) ${ }^{73}$

73 Transcrição de versos de cantoria referindo-se à bandeira de embaixador da Cia dos Faceiros, realizada em janeiro de 2008 pela autora. 


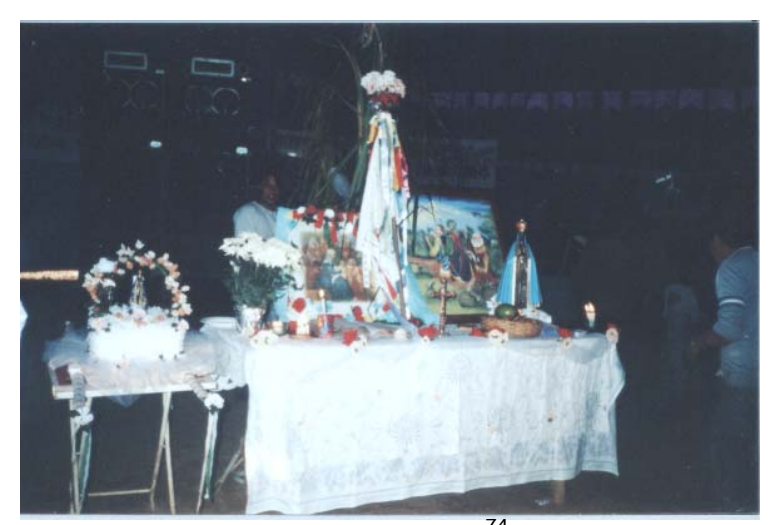

Foto 4.13: Altar $^{14}$

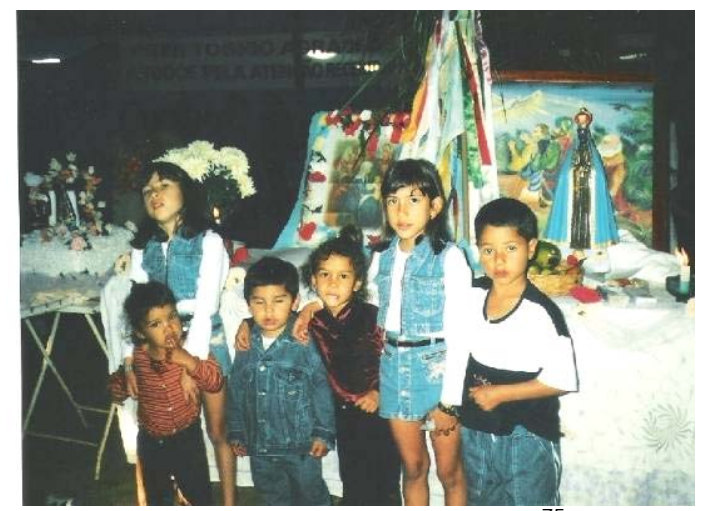

Foto 4.14: Altar com crianças ${ }^{15}$

Para receber as Folias e a bandeira, é comum as famílias organizarem um pequeno altar na entrada das casas ou na sala principal. Nele são colocados os santos de devoção da família e a bíblia, em algumas residências se monta um presépio. Quando a presença do presépio é observada, é motivo para os Foliões mudarem o ritual da visita; este deve ser mais elaborado e cerimonioso. Em muitas companhias, essa informação é obtida antes por um Folião e, quando os Foliões chegam à residência, já estão preparados e o cerimonial decidido, desde a entrada da bandeira até a atuação dos Palhaços.

Quando a família visitada oferece o almoço ou pouso, é comum a montagem de altares e de um presépio; neles são feitos rituais diferenciados: normalmente, no pouso, a bandeira fica no altar junto com instrumentos musicais até o outro dia, para continuar a jornada ou giro. Quando o altar é feito para a saída inicial dos giros e/ou chegada da Folia no dia da festa de Reis, ele é mais elaborado e festivo.

\footnotetext{
${ }^{74}$ Altar da festa de Ribeirão Grande, Ourinhos/SP. Foto cedida pela festeira Maria de Fátima Leite Fonseca, esposa de Cláudio Mello da Fonseca, festeiros de 2009.

${ }^{75}$ Foto cedida pela festeira Maria de Fátima Leite Fonseca festeira de 2009. Ribeirão Grande, Ourinhos/SP.
} 
Os altares são catalisadores do sagrado, é onde as coisas

materiais se tornam santificadas, onde se processa a transferência do material, do profano, para o sagrado. Esses saberes são detidos pelos membros mais experientes das Folias e transmitidos aos que estão chegando durante a vivência, no cotidiano dos giros. Normalmente, os observadores externos percebem que diferentes saberes atuam nas performances dos grupos e que, para obter ou saber decodificar esses conhecimentos, é necessário um aprendizado, como pode ser observado no relato a seguir:

Depois tem uma outra passagem, que eu não sei te falar com detalhes, mas é só perguntar para os mestres das bandeiras, quando as pessoas chega na casa tem uma cruz na porta e tem uma cruz no chão, o que isso representa? É que lá dentro tem um presépio, então eles, para poderem entrar na casa, eles precisam desfazer aquele enigma, senão eles não podem entrar na casa. Lá em Tarumã, deve ter lá uma ou duas pessoas, que poderiam contribuir com alguma coisa nesse sentido. Em Minas tem muito essa cultura, né? Se por acaso a bandeira chega e a pessoa não sabe como desfazer o enigma, ela não entra na casa. ${ }^{76}$

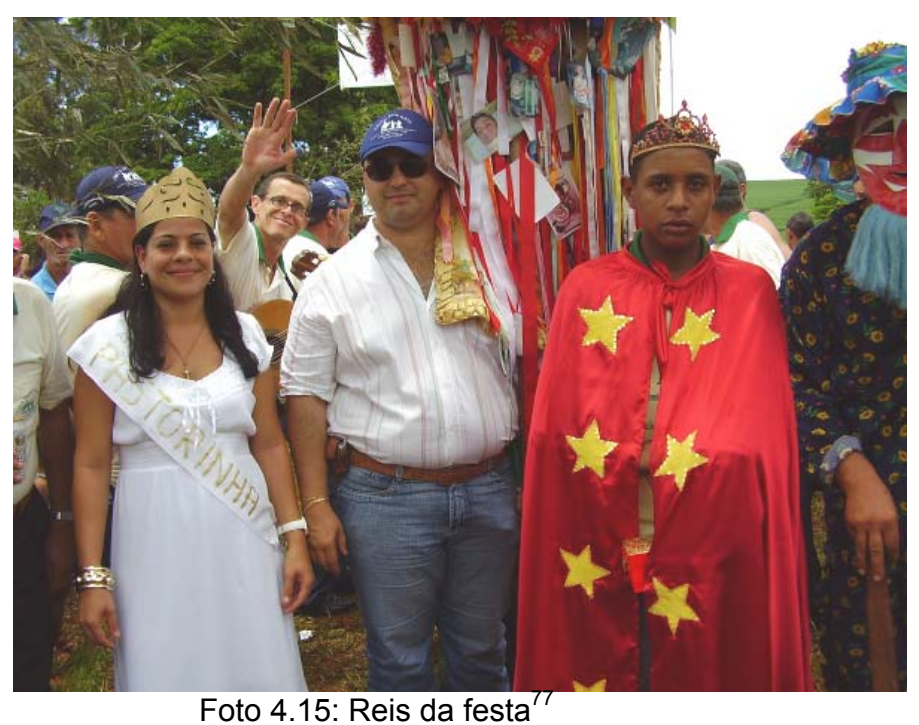

Enquanto essas levas ambulantes amontoavam o cabedal para o régio festejo de seus maiorais, na Capela da Lampadosa erigia-se o trono para a coroação, armava-se o altar do santo Rei Mago [...]

\footnotetext{
${ }^{76}$ Depoimento de folião da cidade de Tarumã/SP, colhido pela autora no encontro de Folias de Reis Assis, em 26 de janeiro de 2008.

${ }^{77}$ Coroação dos reis da Cia. dos Faceiros, na festa de Palmital/SP. Foto da autora, janeiro de 2008.
} 
O Rei e a Rainha, com seus mantos de belbutina escarlate recamados de estrelas, com suas vestiduras cintilantes de lentejoulas e agaloadas, aquele com seu cetro dourado, e está com seu diadema resplandecente, pisavam garbosos à frente de sua corte, levando dois vassalos a duas coroas, vestido de capa e espada, ostentando na cabeleira carapinhada e no pontudo topete fios de corais e miçanga, que lhes desciam em volta como um casco de capacete.

$[\ldots]$

Uma vez entronizados, o capelão, que os recebia à porta do templo, coroava-os ritualmente, conduzindo-os depois à sacristia, onde ouviam ler, marcavam em cruz e assinavam o documento oficial da coroação. (MORAES FILHO, 1979, p. 226).

Nas Festas de Reis, um dos cerimoniais solenes e de grande importância é a coroação do novo Festeiro. A cerimônia é esperada e aguardada com ansiedade pela comunidade; nela, a continuidade da Festa e das tradições recebe a garantia de prosseguimento.

Ser coroado Festeiro ou Imperador reveste e investe o escolhido para essa função de um sentido de poder; ele adquire um novo status. Esta cerimônia marca o fim da Festa e está sempre carregada de muita emoção para quem passa a coroa, pela alegria do dever cumprido com os Santos e com a sua comunidade. Para quem a recebe, existe a certeza de que naquele ano o seu cotidiano será alterado pela preparação da Festa. Para a comunidade, a confirmação de que suas crenças e tradições estão asseguradas.

A coroação assume deste modo, um caráter político e social, bem como explicita o sentido de religiosidade que acompanha as Folias. A coroa é um símbolo de sacralidade, nela o coroado é investido de poder e passa a ser o mediador entre os anseios e desejos da comunidade com o sagrado. Para muitos que assumem essa função, ser festeiro é receber um presente, é estar intimamente ligado com o sagrado. 
Segundo Brandão (2004), não é o Festeiro coroado que estabelece a relação com o divino, esta relação é feita principalmente pela bandeira, pela montagem dos altares; mas o Festeiro é o mediador que possibilita acontecer essa relação entre o sagrado e o grupo, assim como o Embaixador.

A coroa, segundo Chevalier e Cheerbrant (1997, p. 289), "participa não só dos valores da cabeça, cimo do corpo humano, mas dos valores do que sobrepuja a própria cabeça, um dom vindo de cima; ela assinala o caráter transcendente de uma realização qualquer bem sucedida".

Em algumas festas é escolhido um casal da comunidade para representar os coroados, e são eles que transportam e portam as coroas nas cerimônias de encerramento, como ilustra a Foto 4.15.

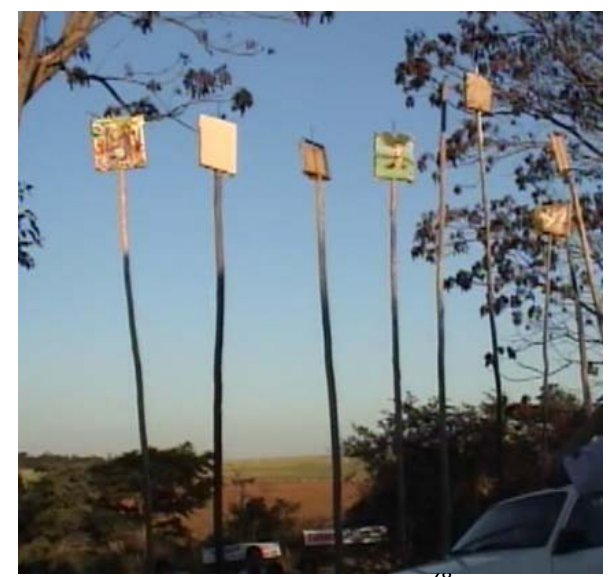

Foto 4.16: Mastros $^{18}$

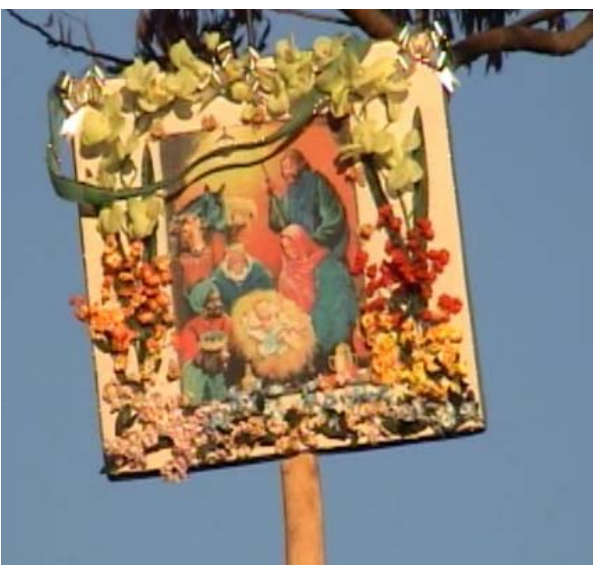

Foto 4.17: Detalhe de mastro ${ }^{79}$

O mastro representa a união entre a terra e o céu, a solidez que sustenta a fé, "árvore da vida".

\footnotetext{
${ }^{78}$ Mastros erguidos na festa da Folia de Reis de Ribeirão Grande, Ourinhos/SP. Foto da autora, Janeiro de 2008

79 Detalhe do mastro com estampa de adoração dos Reis, erguido na festa da Folia de Reis de Ribeirão Grande, Ourinhos/SP. Foto da autora, Janeiro de 2008.
} 
$\mathrm{Na}$ antiguidade e no medievo, em muitas comunidades o levantamento do mastro estava vinculado à fecundidade da terra; conseqüentemente, era símbolo da fartura. Nas Festas Juninas o levantamento do mastro, denominado "socar o mastro" é uma cerimônia carregada de crenças; muitos depositam na cavidade em que será inserido o mastro, sementes, pedidos e fotos, acreditando que este desempenhará a função de elo entre as necessidades terrenas e o sagrado. Em algumas Festas, é comum o levantamento do mastro em homenagem aos Santos Reis. Seus significados não diferem do levantamento de mastro de outras festas religiosas e populares no Brasil.

Os mastros estão presentes em diferentes culturas, desde as cerimônias realizadas nas culturas pré-romanas e pré-cristãs até cerimônias descritas em rituais das culturas ameríndias. Na Europa, os mastros desempenhavam funções vinculadas aos ritos de fertilidade e de nascimento, eram vistos como a "árvore do mundo". Nas tradições celtas, diferentes rituais estavam vinculados ao caráter fálico dos mastros, que eram enfeitados, e danças orgiásticas, principalmente, no primeiro de maio ou nos solstícios, eram realizadas. Nas culturas greco-romanas também havia rituais envolvendo o levantamento de mastros relembrando Átis, o consorte de Cibele, representando a fecundação da Terra - a germinação da vida.

As festividades pré-cristãs que envolviam o mastro fecundando a terra foram duramente perseguidas pela Igreja romanizada, mas as tradições populares as transferiram para os festejos de santos católicos. As danças de pau-de-fita, pau-de-sebo e o levantamento de mastro de muitas festas religiosas ou profanas remontam a essas tradições. 
Na festa de Folia de Reis de Ribeirão Grande - Ourinhos/SP é comum o levantamento de mastro em homenagem aos Reis. Esta tradição é única na região; esse ritual não foi encontrado nas outras Festas pesquisadas.

Á tarde, com a assistência dos régios personagens da manhã, havia as festas públicas comemorativas, os clássicos batuques realizados por negros de diferentes tribos, tendo como teatro o areal de improviso preparado na frente do templo, formando um quadrilátero guarnecido por semicírculos de folhagens, que pendiam do alto de bambus fincados. (MORAES FILHO, 1979, p. 227).



Foto 4.18: Arco da Folia de Reis ${ }^{80}$

Na chegada ou na saída e nas apresentações das Folias fora dos giros, é comum a montagem de três arcos de bambu enfeitados com flores e fitas. Os Foliões param antes do primeiro arco e os donos da casa ou Festeiros vêm recebê-los com atitude cerimoniosa. Cada arco transposto pela bandeira é motivo de uma cantoria e rezas específicas. Para alguns, os arcos simbolizam os Reis, para outros, simbolizam a passagem pelos três reinos.

No primeiro ou no último arco é comum ser colocada uma estrela de cauda. Em algumas Folias, ela é presa em um cordão e, conforme a

\footnotetext{
${ }^{80}$ Arco da Festa de Folia de Reis da cidade de Ribeirão do Sul/SP. Foto da autora, Janeiro de 2008.
} 
bandeira e os Foliões vão adentrando, a estrela é deslocada neste cordão até o presépio, transformando a chegada da Folia em uma grande performance. Essa encenação indica que os Reis foram guiados pela estrela até o Menino.

Os arcos remetem para a curvatura do céu e desempenham o papel de ligação entre o divino e o terreno. Na tradição judaico-cristã, é usada a representação do arco-íris para indicar a reconciliação de Deus com os homens, após o dilúvio. "Porei o meu arco nas nuvens e ele será o sinal da aliança entre mim e a terra." (Gênesis, 9:13). Também pode significar a presença da virgem Maria.

A transposição dos arcos pelos Foliões indica a delimitação de um espaço sagrado e de um espaço profano; o sagrado está no espaço delimitado após a passagem pelo arco. O que se percebe desse ritual é: o lugar em que está a bandeira é sagrado para os Foliões.

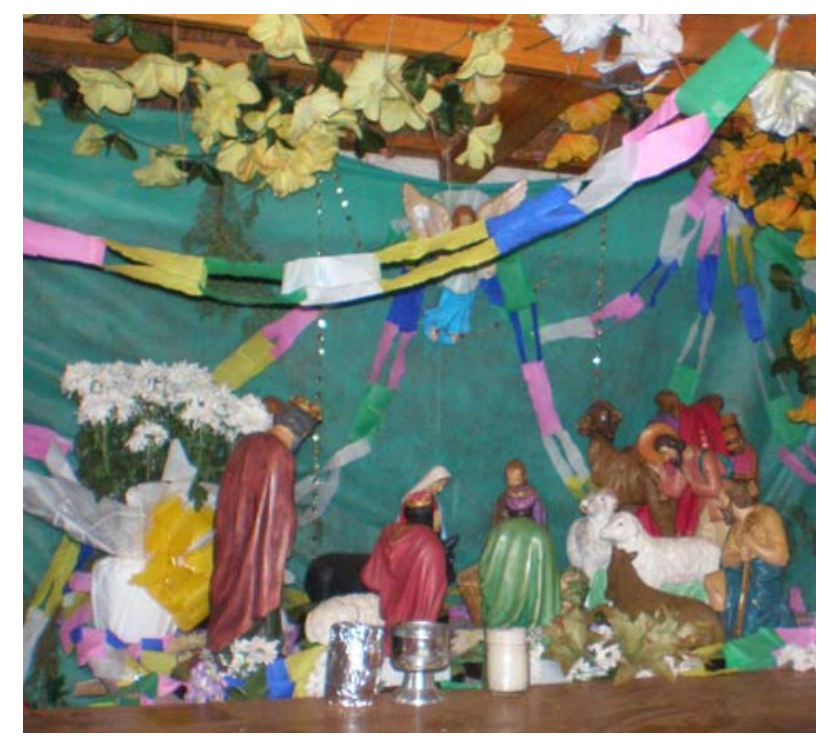

Foto 4.19: Presépio ${ }^{81}$

O presépio representa o nascimento de Jesus. A primeira montagem do presépio é atribuída a São Francisco de Assis, em 1223. Reza a

\footnotetext{
${ }^{81}$ Presépio da Festa de Reis da cidade do bairro de Ribeirão Grande Ourinhos/SP. Foto da autora, julho de 2008.
} 
tradição que o Santo não conseguia explicar de forma clara para os camponeses o texto bíblico da Natividade. Para atingir seu objetivo, ele moldou as principais figuras e montou a cena do nascimento perto da floresta de Greccio. A partir desse episódio, o costume adentrou a Idade Média, e a cena passou a ser montada e representada nas catedrais, castelos e mosteiros. A montagem dos presépios se popularizou no renascimento e durante o barroco.

No Brasil, a montagem dos presépios está presente no imaginário popular desde os primórdios da colonização; prática introduzida pelos jesuítas que utilizaram a mesma estratégia de São Francisco a fim de contar o nascimento de Jesus para os nativos e africanos. Os primeiros portugueses também trouxeram estas representações, nas quais figuravam suas tradições populares.

Existem vários relatos das montagens dos presépios pelos portugueses; neles foram incorporadas, junto às figuras do texto bíblico, representações das atividades e dos diferentes tipos que compunham as sociedades das épocas em que eram confeccionados. Os presépios tornaramse retratos dos costumes dos povos.

No Brasil, também são conhecido como "lapinha" e é possível encontrar grandes presépios de diferentes épocas e em diferentes lugares. Sua montagem e representação estão impregnadas do imaginário popular em todo território nacional.

No Estado de São Paulo, merece destaque o presépio encontrado em Embu das Artes, no complexo arquitetônico da Igreja de Nossa Senhora do Rosário (1690), considerado o conjunto jesuítico mais expressivo de São Paulo; hoje, Museu de Arte Sacra e Convento do Embu. Esse presépio 
é um exemplo dos santos de roca feitos pelos Jesuítas para montar dramatizações com fins de evangelização. Também se destaca o conjunto de presépios de diferentes locais do Brasil e de outros países que compõem o acervo do Museu do Presépio, anexo ao Museu de Arte Sacra de São Paulo, dentre os quais merece se mencionado o belíssimo Presépio Setecentista Napolitano, exemplar conhecido em todo o mundo.

$\mathrm{Na}$ atualidade encontram-se presépios montados nos mais diferentes lugares: praças públicas, centros comerciais, edifícios religiosos e na maioria das residências cristãs romanizadas. Alguns rituais ainda são mantidos em relação aos presépios, como: só colocar o menino Jesus na manjedoura no dia vinte cinco de dezembro; do início de sua montagem até o dia primeiro de janeiro os reis estão direcionados para o presépio; desse dia até o dia 6, são dispostos com as costas para a manjedoura, simbolizando o retorno da viagem. A partir do dia de Reis, 06 de janeiro, os presépios costumam ser desmontados.

Nas Folias, o ritual de adoração ao Menino é feito em frente ao presépio e é também nesse momento que os Palhaços se colocam de joelhos e pedem perdão pelas faltas cometidas por todos. Nesse momento, é comum um dos Palhaços relatar em versos os textos bíblicos referentes à natividade. 


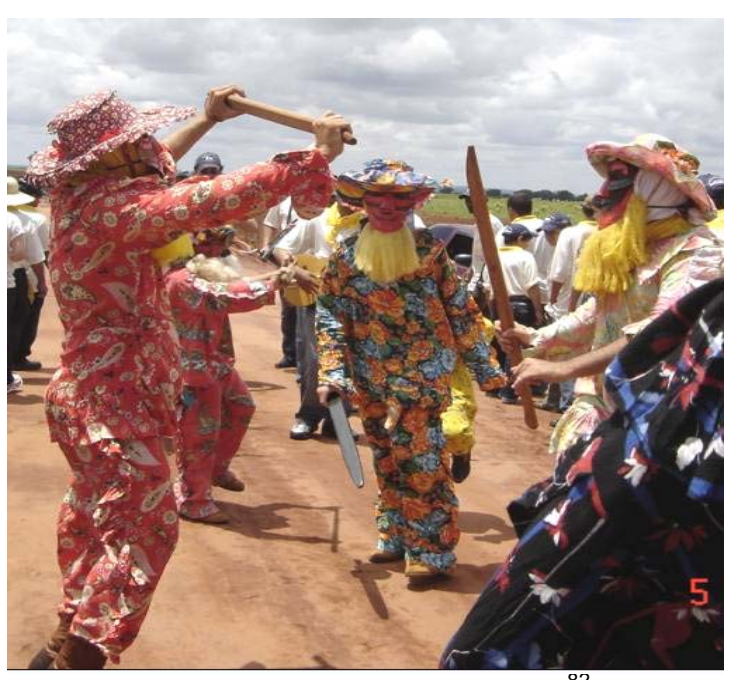

Foto 4.20: Dança com bastões ${ }^{82}$

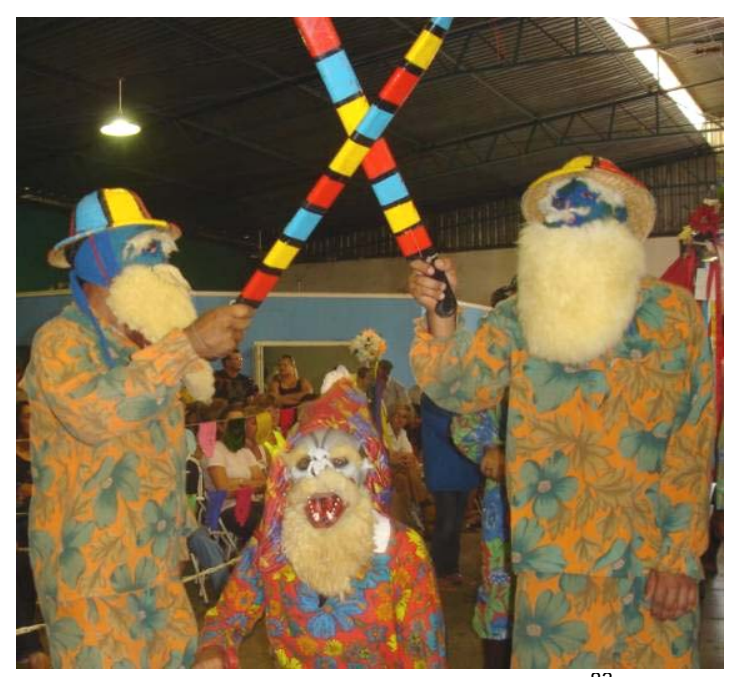

Foto 4.21: Palhaços com bastões ${ }^{83}$

Normalmente, os Palhaços ou Bastiões se fazem acompanhar por bastões de madeira enfeitados e coloridos, alguns lembrando o formato de espadas que remetem às espadas usadas pelos soldados de Herodes. Esses bastões, junto com o sapateado, servem para marcar ritmo durante as cantorias em algumas Companhias, também algumas vezes são cruzados para cima, formando um corredor protetor por onde os Foliões chegam até a bandeira.

As espadas muitas vezes são associadas à idéia de virtude e bravura, foi símbolo da Guerra Santa durante as Cruzadas, era vista como um "fragmento da Cruz de Luz", no medievo era símbolo da justiça assim como nos dias atuais. A espada pode banir o mal; quando Deus expulsou Adão e Eva do Paraíso, colocou dois anjos guardando a entrada para a árvore da vida, cada qual segurando uma espada de fogo que simboliza bondade e poder. Portanto, Deus é generoso e soberano ao mesmo tempo. (Gênesis, 3,24).

Nas tradições cristãs, a espada é a arma dos cavaleiros nobres e dos heróis cristãos. (CHEVALIER; GHEERBRANT, 1997).

\footnotetext{
${ }^{82}$ Foto da autora, Janeiro de 2008.

83 Idem.
} 


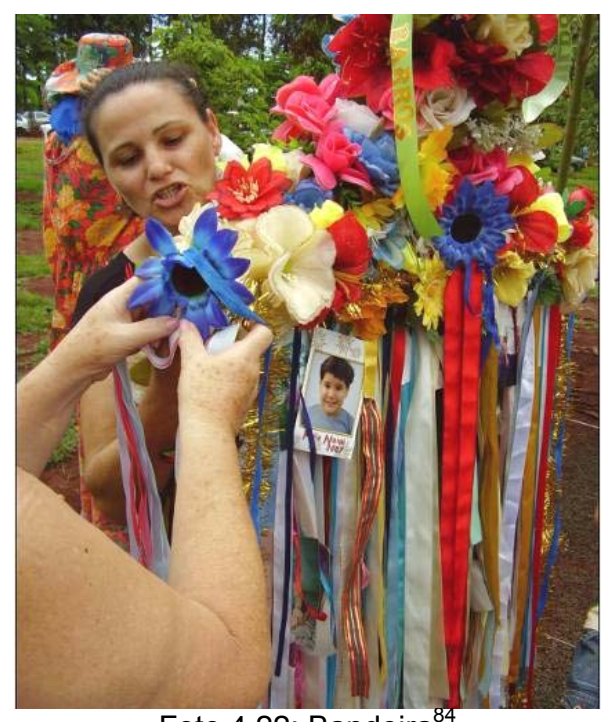

Foto 4.22: Bandeira

O principal uso das cores nas Festas de Reis está presente nas fitas que são colocadas na bandeira, como súplica ou gratidão, e também nos instrumentos musicais e nos bastões dos Palhaços.

Segundo Garbosi (2002), o branco é a cor do menino Jesus, da paz; o azul é a cor da Virgem Maria, do céu; rosa, a cor de São José, símbolo do amor, da paciência; o amarelo, o ouro presente ofertado, assim como vermelho, o fogo representando o incenso e o verde, a cor da mirra.

Como manifestação, as Folias são festas muito coloridas e alegres, desde as fantasias dos Palhaços, os uniformes dos Foliões, os enfeites floridos, a bandeira e as bandeirinhas que decoram os espaços.

Pela própria característica e múltiplas influências culturais no Brasil, as cores ganham e são inseridas em uma diversidade de situações, tais como: os rituais religiosos, cívicos e nas crenças supersticiosas dos diferentes seguimentos da sociedade. Desse modo, o preto caracteriza o luto. Na liturgia do catolicismo, as cores desempenham papel preponderante,

\footnotetext{
${ }^{84}$ Foto da autora, Janeiro de 2008.
} 
Branco é a pureza, alegria, dedicação aos santos não martirizados, à Virgem Maria. Vermelho é sangue, sangue dos mártires, língua de fogo de Pentecostes. Roxo, mortificação, tristeza, recolhimento, [...] quaresma Semana Santa, [...] Verde, futuro, confiança, domingo depois de Pentecostes. (CÂMARA CASCUDO, 2001, p.158).

Ainda segundo o mesmo autor, em determinadas comunidades são comum promessas em que o solicitante se compromete a usar as cores do santo invocado: "azul e branco, Nossa Senhora de Lurdes; branco e marrom, Santa Teresinha do Menino Jesus; vermelho e branco, o Sagrado Coração de Jesus; vermelho, o Santíssimo Sacramento; roxo, Nosso Senhor dos Passos ou o Crucificado". (CÂMARA CASCUDO, 2001, p.159). O vermelho, como cor predominante nas liturgias populares, pode estar associado ao uso e à facilidade da extração dessa cor nos artefatos originários, bem como pelos portugueses, no período colonial.



Foto 4.23: Máscara ${ }^{85}$

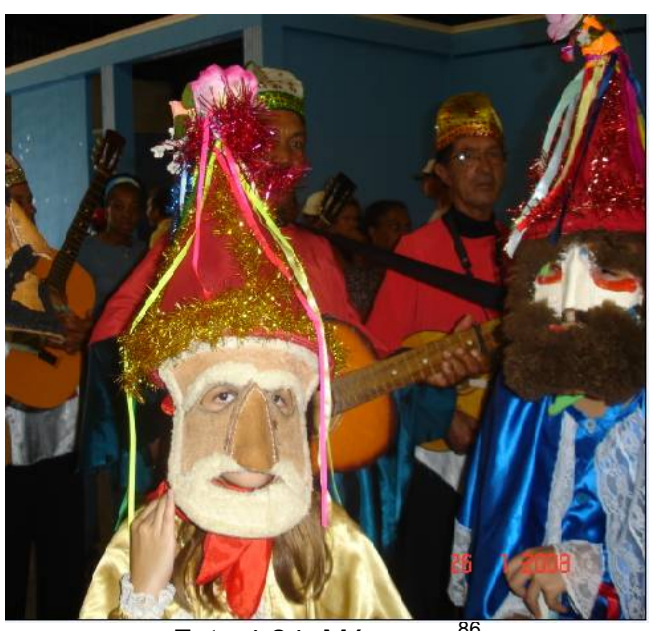

Foto 4.24: Máscaras ${ }^{86}$

\footnotetext{
${ }^{85}$ Foto da autora, Janeiro de 2008

${ }^{86}$ Idem
} 


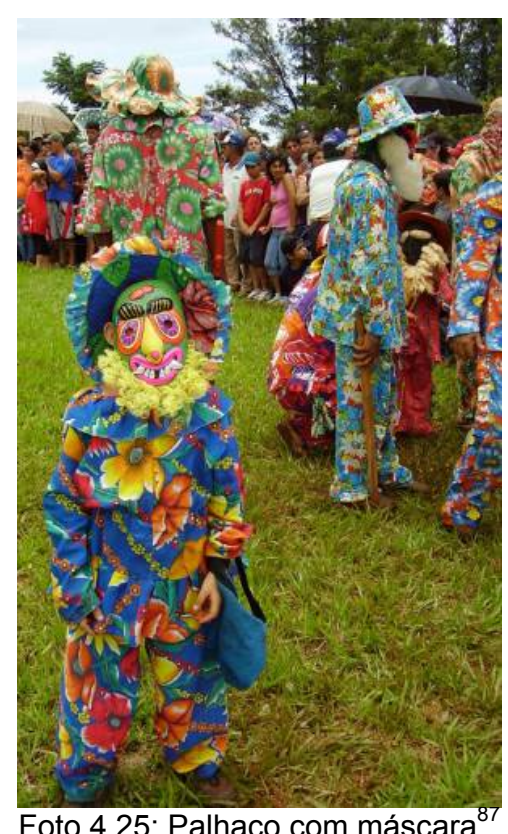

As máscaras são usadas pelos Palhaços ou Bastiões. Em algumas Folias, as máscaras são usadas com a intenção de atrair para si os maus pensamentos e maus olhados que são enviados para os Foliões ou desfazer os acontecimentos negativos que poderão ocorrer durante as festividades. Em outras Folias, sua aparência grotesca é para lembrar os soldados que perseguiram o Menino Jesus. Em muitas culturas as máscaras revelam as tendências bipolares dos sentimentos humanos e seu uso provoca catarses.

No Brasil, o uso de máscaras está intimamente ligado a muitos rituais dos povos originários, assim como na África. Deste modo, as máscaras das Folias podem estar vinculadas às tradições dessas culturas, no imaginário popular.

Segundo (CHEVALIER; GHEERBRANT, 1997), as máscaras ainda preenchem uma função transcendental, materializando o incognoscível.

\footnotetext{
${ }^{87}$ Foto da autora, janeiro de 2008.
} 
É pela máscara que, em muitas culturas, principalmente nas vinculadas a cultos animistas, as relações com o transcendente são captadas.

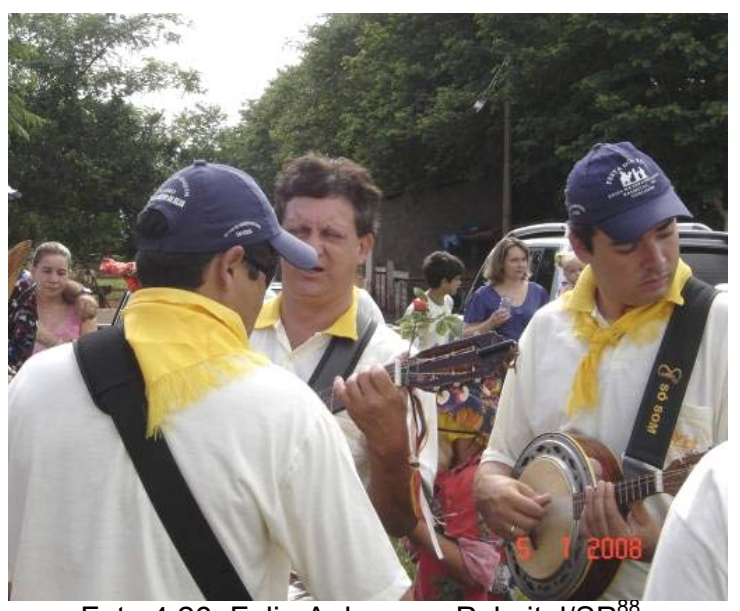

Foto 4.26: Folia Anhumas, Palmital/SP

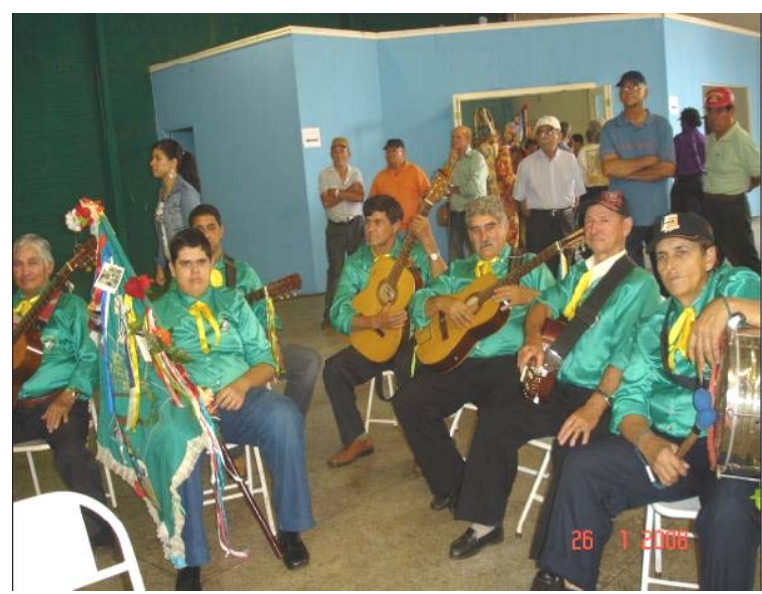

Foto 4.27: Folia de Tarumã/SP ${ }^{89}$

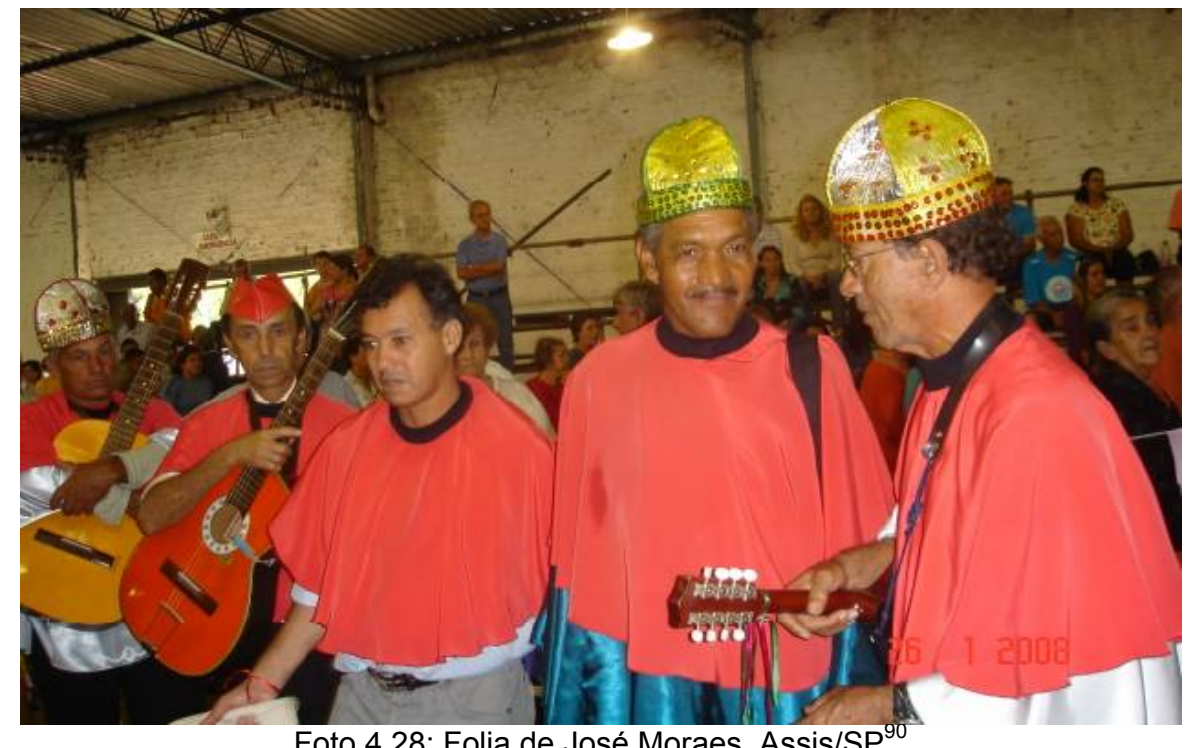

Foto 4.28: Folia de José Moraes, Assis/SP

E os foliões africanos, de calça e suspensórios, de fachas encarnadas e azuis a tiracolo, com a cabeça adornada de penas e o peito listrado de tiras vistosas, tamborilavam em seus tamborins de dança, faziam evoluções com a perna no ar, cantavam suas cantigas [...] (MORAES FILHO, 1979, p. 226).

\footnotetext{
${ }^{88}$ Giro da Folia Anhumas, em Palmital/SP. Foto da autora, Janeiro de 2008.

${ }^{89}$ Encontro de Folias, em Assis/SP. Foto da autora, Janeiro de 2008.

90 Idem.
} 
Comumente, as Folias adotam uniformes ou indumentárias para serem identificadas. Também chamadas de fardas, são geralmente vistosas. Algumas adotam fantasias de reis para o Embaixador e segunda voz, outras adotam uma vestimenta comum a todos; umas são muito elaboradas, com franjas, com cores variadas e brilhos; outras se restringem à camiseta com a estampa do nome da Folia; podem também usar somente adereços, como chapéus, bonés e distintivos nas roupas.

As indumentárias caracterizam o estilo do grupo, mais festivo ou mais formal, não existe uma regra para sua elaboração.

\subsection{Os Diferentes Rituais da Folia}

As festas e folguedos populares caracterizam atividades performáticas. Nelas os saberes dos rituais constituem códigos que devem ser conhecidos por todos os seus participantes. Essas performances geram os rituais que dão sentido às festas, sagradas ou profanas.

São também os rituais que fazem uso dos diferentes elementos iconográficos já descritos e seu uso caracteriza um conhecimento codificado que deve ser conhecido por quem conduz o ritual, assim como por quem dele participa. O não conhecimento dos rituais transforma o participante em um mero espectador de um acontecimento festivo, principalmente quando se trata de manifestações populares. 
Nas festas pesquisadas, a decodificação dos rituais é um conhecimento dominado por todos, e é este conhecimento que gera um sentimento de pertencimento ao grupo e àquela comunidade. $\mathrm{E}$ quando um participante leigo ou visitante indaga sobre o sentido desses rituais, existe uma prontidão de todos em transmitir este conhecimento, pois é através dele que o visitante se torna integrante.

Nas Folias, os principais rituais são: o início da Folia, o início do giro e o giro propriamente dito, a "reza" do terço, o pouso, os almoços, jantares e lanches, a chegada da Folia e o dia da festa.

II. ${ }^{\text {mo }}$ e Ex. ${ }^{\text {mo }}$ Sr. Desembargador Ouvidor Geral do Crime: - Dizem o Imperador, o Rei, a Rainha e mais adeptos da nação do Santo Rei Baltazar, que eles costumam, em os domingos e dias santos festivos, tirar as suas esmolas por meio de danças e brinquedos que fazem com todo o recato e sossego, sem inquietação e perturbação alguma como é notório, cujas esmolas são aplicadas com o necessário às festividades do Santo Rei: e porque do mesmo modo têm alcançado do Ex.mo Sr. Conde Vice-Rei, como se vê no documento junto, e como querem também a concessão de $V$. Ex. ${ }^{a}$ para o mesmo fim acima descrito, e assim também querem no dia dos Reis próximo coroar para rei da nação Rebolo a Antônio, fâmulo do mesmo II.mo e Ex.mo Sr. Conde Vice-Rei, e que nesse dia pretendem sair com seus instrumentos e danças da mesma nação, para ser feito com maior obséquio e dançar - pelo que pedem, etc."

Datada de 3 de dezembro de 1748, a esta petição, seguida das assinaturas em cruz dos requerentes, acompanha favorável despacho, e a Irmandade do Santo Rei Baltasar entregava-se ao gozo preparativo da licença do magistrado. (MORAES FILHO, 1979, p. 225).

Logo no alvorecer, os foliões se encontram para organizar os preparativos do início do "giro"; é comum serem proferidas orações pedindo proteção para o grupo e para a jornada que está prestes a se iniciar. Quando a Bandeira fica na casa do gerente, ela é retirada com cerimônia e encaminhada para a casa do festeiro do ano; caso se encontre na casa do festeiro, é o momento que todos se reúnem para começar o "giro". Todas as orações e 
cantorias que antecedem a saída são feitas e acompanhadas com muita cerimônia e respeito.

O festeiro do ano prepara a residência e espaços externos com barracas e tenda para este acontecimento. É montado um altar para receber a bandeira, bem como um presépio; nele é rezado um terço, muitas vezes cantado, pedindo proteção para o grupo; também solicita-se a benção dos instrumentos. É chegado o momento de venerar a bandeira, que é passada para os Foliões.

Nessas rezas, são explicitados os desejos dos foliões, bem como os relatos das graças alcançadas. Muitas vezes essas cerimônias são presididas por membros mais antigos da comunidade, rezadores e benzedores, ou por pessoas que exercem funções de destaque na Igreja Romanizada: em algumas ocasiões o padre da paróquia local conduz essas cerimônias.

Após as cantorias e as rezas, é servido um almoço; neste momento, a sociabilidade do grupo é restabelecida, parentes e amigos se encontram, as novidades são trocadas, os projetos para o ano que se inicia explicitados. É o encontro dos foliões com os membros da sua comunidade. Os almoços irão se repetir durante todos os dias do giro, sempre precedidos de orações e cantorias; neles acontece a pausa dos foliões para descanso e para o fortalecimento do grupo.

O Giro é o percurso para fazer as visitas nas casas dos membros da comunidade dos foliões. Na tradição, o giro representa o percurso que os Reis fizeram até encontrar o Menino Jesus; é uma peregrinação, uma jornada. É ir ao encontro do sagrado. A casa do festeiro do ano, no imaginário 
dos foliões, representa a gruta de Belém; assim sendo, a festa de encerramento no dia de Reis relembra este encontro.

Os giros representam muito mais que visitas aos membros da comunidade dos foliões, são momentos de partilhar uma experiência sagrada, espiritual. A peregrinação é um ritual presente no imaginário dos povos, que se perde no tempo; sempre os homens se deslocaram para encontrar o sagrado em diferentes culturas e, na Europa Medieval, as rotas sagradas e os caminhantes, peregrinos, eram comuns. Ser peregrino, em qualquer situação religiosa, não difere muito quanto ao propósito; o que desencadeia essa prática é sempre a fé. Esses rituais sofreram alterações com os avanços da modernização, mas a essência continua imutável.

Nas folias o giro é muito bem organizado: as casas que serão visitadas no dia são avisadas antecipadamente, e quem deseja receber a Bandeira de Reis procura os foliões e expressa essa intenção. O almoço e o pouso são previamente combinados, mas os foliões nunca negam visitar uma casa que solicita sua presença sem aviso, "solicitação a Santos Reis não pode ser negada". Em algumas folias, os foliões costumam cantar até tarde da noite, para atender aos pedidos; em outras, o costume não permite atividade até tarde.

Normalmente os foliões cantam pedindo licença para entrar nas casas; depois, atendem alguma solicitação específica dos donos quando feita, e cantam para pedir uma oferta e para agradecer. Procuram acolher sempre a intenção dos donos da casa. As atividades são sempre supervisionadas pelo gerente ou pelo embaixador, os rituais são estipulados de acordo com regras de cada grupo; mas, normalmente, na casa em que o 
presépio está armado, costumam ser mais demorados. A Bandeira é sempre o elemento principal de todas as atividades das visitas; é a primeira a entrar nas casas e a primeira a sair. Geralmente, os donos da casa ficam aos portões ou porteiras para recebê-la e, ao chegar a Folia, o Alferes passa a Bandeira para o dono da casa e é este que a carrega para sua residência. É um momento solene; para muitos, é como receber realmente Santos Reis em sua casa.

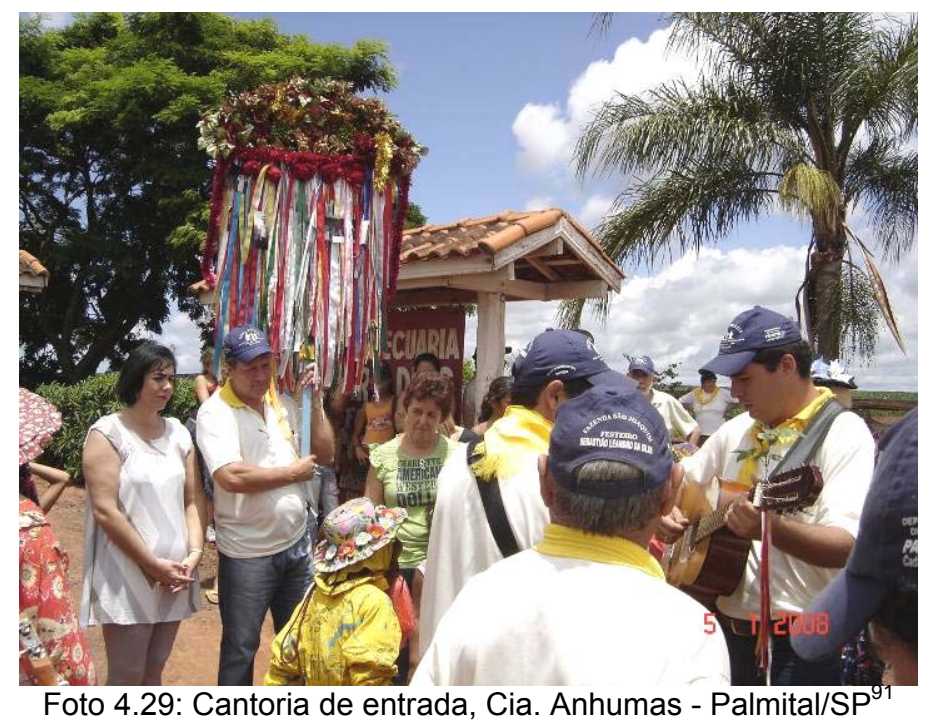

É no giro que as prendas são solicitadas. Quando a oferta é significativa, é motivo de uma cantoria especial, sempre feita de improviso. As ofertas são anotadas e retiradas posteriormente. Hoje, normalmente, os foliões se deslocam em carros, caminhonetes, ônibus, e as ofertas possíveis de serem transportadas são levadas pelo grupo.

No giro, quando os foliões dormem na casa que ofereceu pouso, após as cerimônias de cunho religioso, é servido o jantar e, normalmente, finalizado com atividades festivas. Quando os foliões não

\footnotetext{
91 Donos da casa segurando a bandeira enquanto os foliões cantam pedindo permissão para entrar. Foto cedida pela Cia. dos Santos Reis Água de Anhumas - Palmital/SP. Janeiro de 2008.
} 
pernoitam na casa do pouso, em algumas folias a Bandeira permanece e o giro se inicia na manhã. Hoje, com a facilidade de transporte, após o jantar, normalmente, a bandeira e os foliões partem. O giro é finalizado no dia da festa de encerramento.

E pelas ruas, pela cidade, internando-se nas fazendas do Engenho Velho, do Engenho Novo, do Macaco, de Santa Cruz, nos limites da autorização concedida, levas de pretos, dançando e cantando, rufavam caixas de guerra, tangiam instrumentos músicos de seus climas natalícios, recebendo esmolas profusas, dádivas valiosas, que entravam para o cofre da irmandade, por conta da qual corria a despesa da festa. (MORAES FILHO, 1979, p. 226).

A "reza" do terço faz parte do ritual da saída das folias e da chegada no dia da festa de encerramento. Também é rezado quando solicitado pela família visitada e no pouso; acontece sempre diante do altar ou do presépio. Neste momento, todos se posicionam em círculo, menos os palhaços, que só são admitidos após a reza e sem a máscara. O terço é "puxado" por um folião ou pelo gerente, pela dona da casa ou membro da comunidade conhecido por exercer essa função. Durante a "reza" do terço, as mulheres da comunidade exercem papel relevante.

Normalmente é explicitada a intenção pela solicitação do terço em intenção a graças recebidas ou em memória de membros falecidos. Após o seu término, geralmente é servido um almoço, jantar ou lanche (merenda) para todos os foliões.

A última visita do dia é feita na casa que oferece o pouso e o jantar aos foliões. É um momento festivo, normalmente, oferecido com a intenção de pagar promessas aos Santos Reis ou de dar continuidade a intenções feitas por antepassados da família. Em algumas famílias, é uma tradição mantida com muita devoção. 
Rituais como: montagem de altares e dos três arcos, decoração da residência e de outros espaços, preparação de farta comida fazem parte do pouso. Também a presença dos vizinhos, amigos ou parentes é solicitada. Hoje, em algumas comunidades, os dias de pouso foram ampliados, ou restritos aos finais de semana, deslocando a festa para depois do dia 6 de janeiro.

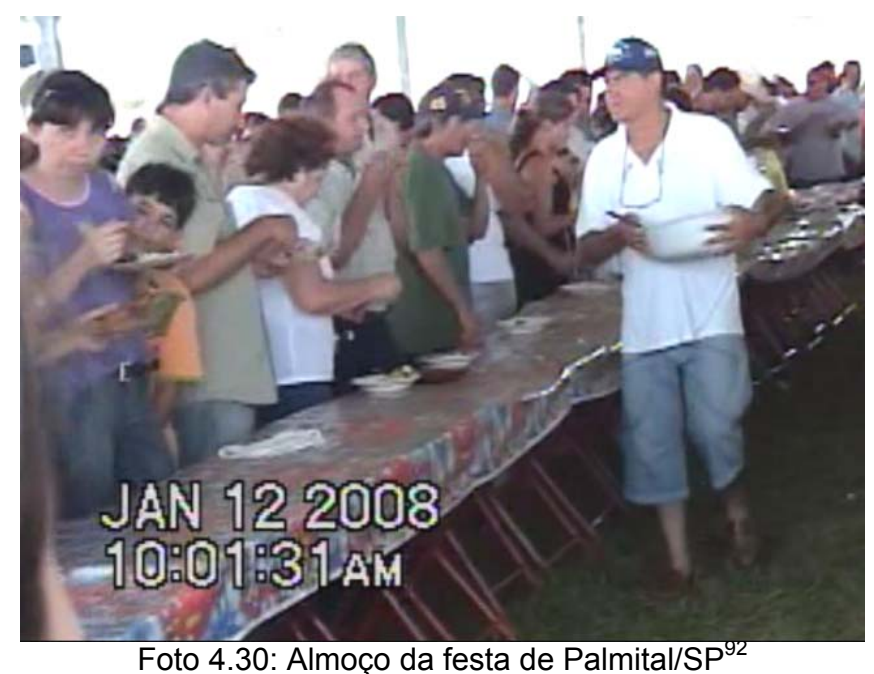

Os almoços e os jantares nas Folias de Reis congregam todos os participantes dos giros e, no encerramento das folias, assumem o caráter de grande festividade.

Remontam ao sentido universal do banquete, da fartura. Estão associados às atividades de trabalho (mutirões) que ainda são encerradas partilhando refeições. No Brasil, essas práticas eram e ainda são atividades corriqueiras dos bairros rurais; neles, após o trabalho, partilham-se os alimentos numa "janta coletiva" que muitas vezes termina em festa, danças e bailes.

O partilhar o alimento traduz a comunhão com seus iguais e com a natureza. O ingerir o que provém da terra ou o que dela pode ser

\footnotetext{
${ }^{92}$ Foto da autora, Janeiro de 2008.
} 
retirado, transforma-se num ato de comunhão com a grande Mãe "Gaia". Neste momento, a energia vital de sobrevivência é assimilada.

Em diferentes culturas, o "banquete" é um ritual para suprir o corpo e o espírito, na cultura clássica grego-romana estava associado à vitória. O banquete é sempre oferecido por alguém para comemorar alguma coisa: é uma partilha dos sentimentos de quem o oferece, normalmente, gratuito. $\mathrm{Na}$ tradição Judaico-Cristã, os banquetes sempre estiveram associados a comemorações que relembravam e indicavam a comunhão com o sagrado - a Páscoa dos Judeus é comemorada em torno do ritual da partilha de alimentos com familiares e amigos da mesma forma que a comunhão dos católicos relembra e celebra um banquete. No banquete, a sociabilidade da comunidade se faz por inteiro, desde o momento da organização do seu preparo até os comentários finais.

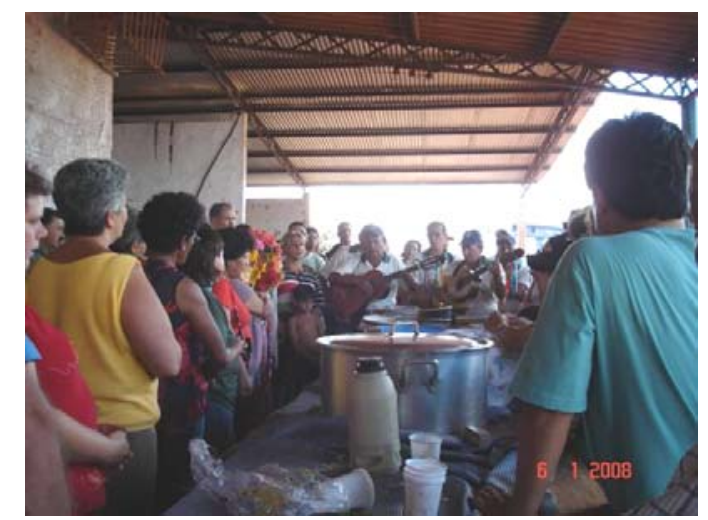

Foto 4.31: Cantoria em agradecimento de almoço ${ }^{93}$

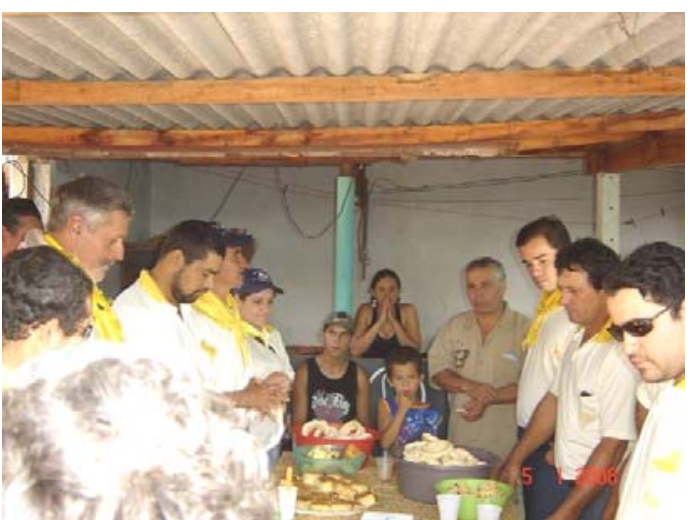

Foto 4.32: Oração em agradecimento a almoço ${ }^{94}$

Nos rituais das Folias, os almoços são acontecimentos marcantes, seu desenrolar segue praticamente o mesmo ritual do almoço do

\footnotetext{
93 Orações e cantoria em agradecimento pelo almoço oferecido à Folia durante o giro - Palmital/SP. Foto da autora, Janeiro de 2008.

94 Orações e cantoria em agradecimento pelo almoço oferecido à Folia durante o giro - Palmital/SP. Foto cedida pela Cia. de Santos Reis Águas de Anhumas, Janeiro de 2008.
} 
dia da festa. Antes de ser servido, os foliões cantam agradecendo os alimentos ofertados, o empenho do festeiro ou membro da comunidade que está oferecendo e acolhendo os foliões; agradecem a todos que colaboraram no seu preparo. Comer sem agradecer é uma falta grave que transgride toda tradição das Folias. Ao fim das refeições os foliões também entoam e expressam louvores de agradecimentos.

O cardápio do almoço varia de região para região. Nele, são explicitadas as tradições alimentares pertinentes a cada grupo. Na região de Ourinhos, a forte presença de migrantes mineiros determina um cardápio vinculado às tradições alimentares deste estado, como: arroz, feijão, leitoa frita e assada. Nas festas da região, o "lombo recheado" é uma tradição. Uma parte da carne de porco é cortada em formato de mantas, recheadas com carne bovina moída bem temperada com alho e sal; enroladas e amarradas no formato de rocambole, passando por um cozimento e, para finalizar seu preparo, são fritas. Também é servido um refogado de carne com batata e frango frito. Ainda, para completar o cardápio, um bom churrasco se faz necessário, resultado do contato com as tradições alimentares do sul do país, do mesmo modo que uma bela macarronada, vinculada à imigração italiana.

O almoço da chegada ou o almoço de Reis é o mais aguardado pela comunidade; nele, todos se envolvem, desde os preparativos para sua organização e decoração, preparo dos alimentos, bem como em todos os outros rituais que o antecedem, como a montagem do presépio, dos arcos para receber a Folia, a organização do terço e, em alguns lugares, há uma missa rezada por um padre convidado. 


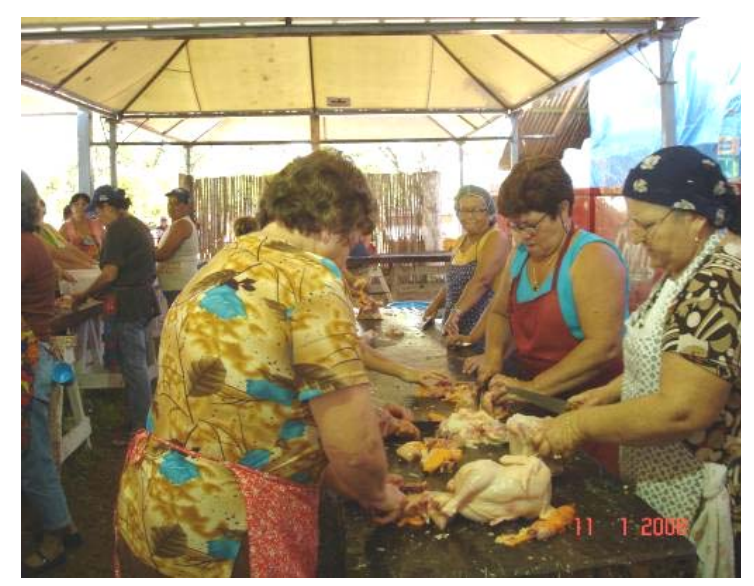

Foto 4.33: Mutirão para preparar o frango, Palmital/SP ${ }^{95}$

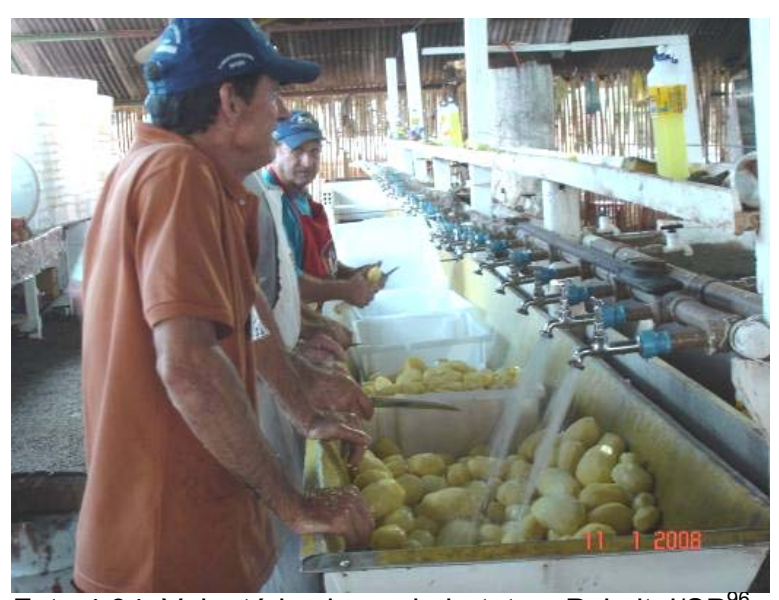

Foto 4.34: Voluntários lavando batatas, Palmital/SP ${ }^{96}$

A abundância de comida tem vários significados e está associada à fartura de alimentos para o ano que se inicia; outros acreditam que comer da comida de Santos Reis traz sorte, ritual repetido todos os anos. A festa e o almoço de Reis, por diferentes motivos, fazem parte dos rituais que marcam o início do ano de muitas pessoas da região. Muitos se deslocam de longe, até de outros estados, para participar.

O almoço de Reis é revestido do sentido de partilha. A oferta de todos é compartilhada com todos; desse modo, as diferenças de classes deixam de existir; todos comem da mesma comida, à mesma mesa. Em Palmital/SP, devido à grande dimensão da festa, um membro da comunidade encarregado pela organização do almoço fez questão de explicitar, várias vezes durante a pesquisa, que o cardápio elaborado e que estava sendo preparado, era o mesmo para todos. Dizia: "Aqui, todo mundo come a mesma comida, não tem diferença para rico, pobre, prefeito, deputado, gente

\footnotetext{
${ }^{95}$ Foto da autora, Janeiro de 2008.

${ }^{96}$ Idem.
} 
importante, é a mesma comida; e ninguém é servido separado, come todo mundo junto".



Foto 4.35: Sacas de batatas e cebolas doadas para almoço da Festa de Reis - Palmital/SP ${ }^{97}$

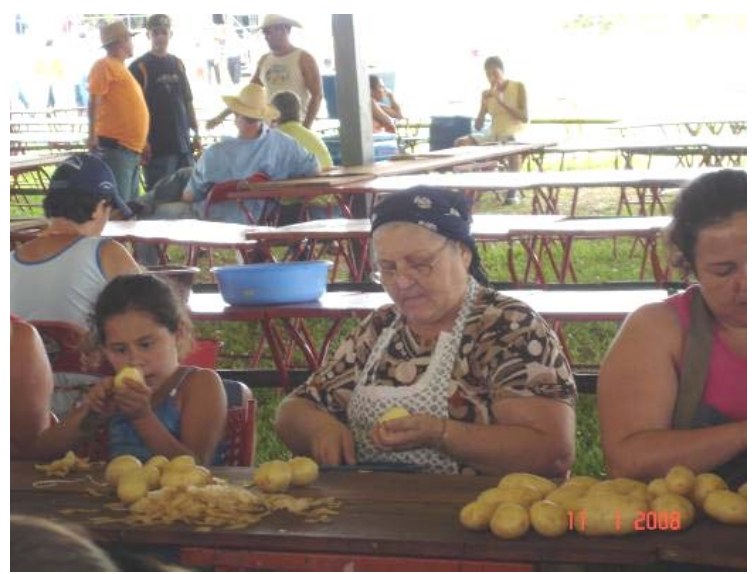

Foto 4.36: Participação de voluntários de todas as idades - Palmital/SP ${ }^{98}$

Nas festas pesquisadas, é muito importante que todos saibam

o quanto foi arrecadado e o quanto foi preparado de comida para o almoço de

encerramento das Folias de Reis, como esclareceu o responsável por administrar a organização do almoço ${ }^{99}$ :

Neste ano foram preparadas doze mil quilos de carne de porco, quinze cabeças de gado que equivale aproximadamente quatro mil quilos, dois mil quilos de frango, quatrocentos e oitenta quilos de feijão, quinhentos quilos de arroz, mil e quinhentos quilos de batata, cento e quarenta quilos de alho, quarenta quilos de sal, mil e duzentos quilos de macarrão e setenta e cinco quilos de massa de tomate, entre outros.

Neste relato, explicita-se uma característica marcante das

Festas de Reis e de todas as festas brasileiras: comida em fartura.

O banquete foi servido ao ar livre, numa comprida mesa de tábuas emendadas sobre cavaletes, ao longo da aléia do pomar da fazenda, debaixo das laranjeiras.

\footnotetext{
${ }^{97}$ Foto da autora, Janeiro de 2008.

98 Idem.

99 Depoimento prestado à autora pelo chefe da cozinha, em 10 de Janeiro de 2008, durante o preparo do almoço de encerramento da Festa de Folia de Reis de Palmital/SP.
} 
Estava ali, naquela mesa enorme, aos olhos gulosos dos convivas, uma profusão de tabuleiros, bandejas e terrinas fumegando o bom cheiro quente de leitoas e pacas assadas, de perus e frangos recheados, de lingüiças, tutus e arroz solto, de mistura com garrafas e vinho zurrapa e pinga da cabeça. (CHRISTO, 1960, p.97)

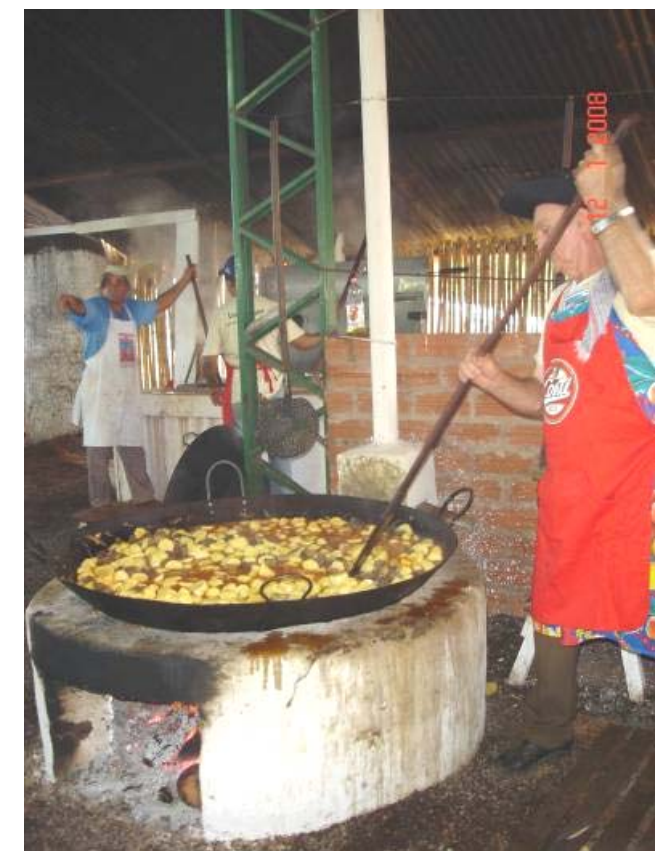

Foto 4.37: Preparo de um dos pratos servidos no almoço da festa de Palmital/SP ${ }^{101}$

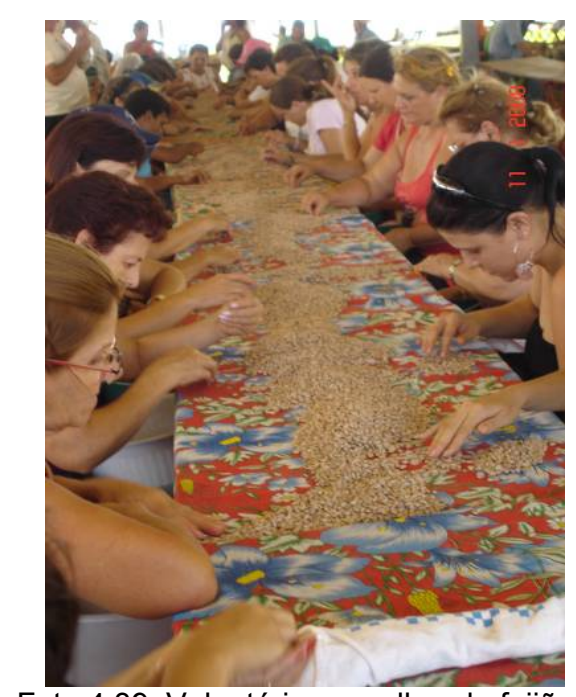

Foto 4.39: Voluntários escolhendo feijão Palmital/SP ${ }^{103}$

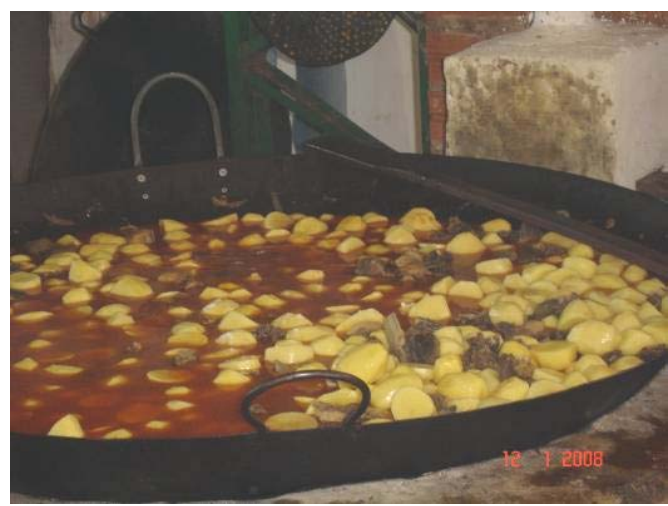

Foto 4.38: Detalhe do tacho de preparo de carne com batatas - Palmital/SP ${ }^{102}$

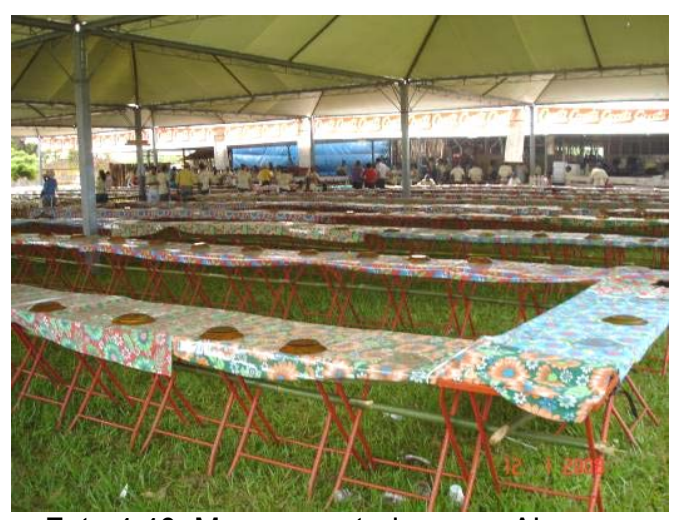

Foto 4.40: Mesas montadas para Almoço Palmital/SP ${ }^{104}$

\footnotetext{
${ }^{100}$ Descrição de um banquete, encontrado no livro Fogão de Lenha, de Maria Stella Libânio Christo, que aproxima-se do almoço documentado em Palmital/SP.

${ }^{101}$ Foto da autora, Janeiro de 2008.

102 Idem.

103 Idem.

104 Idem.
} 
Esse simbolismo, da partilha da refeição, gera sociabilidade que desencadeia a igualdade de todos. Nas Festas de Reis as mesas são coletivas, come-se em pé, numa atitude propicia a aglutinação dos grupos de amigos. As mesas são usadas somente para apoiar as travessas em que são servidos os alimentos, os talheres e os pratos. Dividir a alimentação é um ato de celebrar a vida, é uma atitude dialética onde o que foi retirado da terra e perdeu a vida pode gerar energia para manter a vida dos homens, é o renascer, o reviver. Comer com seus pares e com abundância são práticas que geraram inúmeros rituais em todas as culturas.

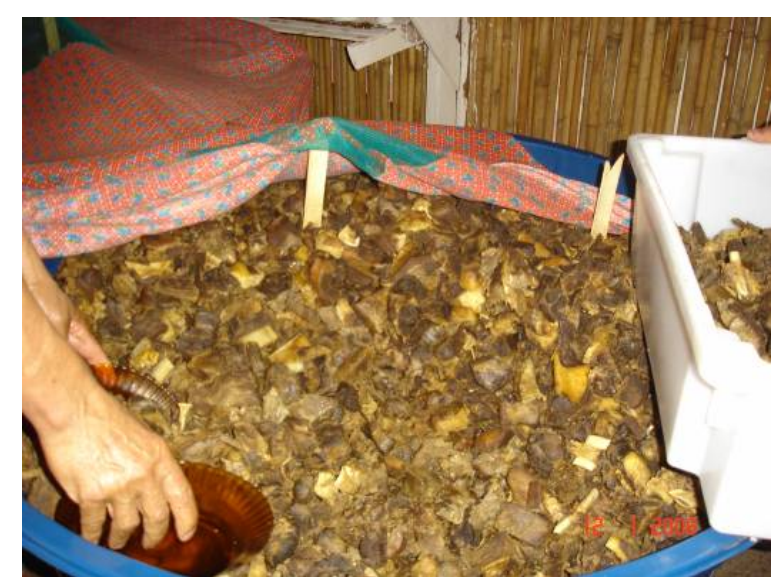

Foto 4.41: Carne preparada para almoço da festa de Palmital/SP ${ }^{105}$

Também no Brasil, nas culturas dos povos originários e nas africanas transplantadas, alimentar-se coletivamente faz parte dos constantes e diferentes cerimoniais que congregam todos em irmandades.

$\mathrm{Na}$ tradição, o dia da festa de Santos Reis é 6 de janeiro, mas na atualidade, por diferentes motivos, a festa pode sofrer deslocamentos. Em Ourinhos, a Festa da Folia não está inserida no ciclo natalino, mas no junino.

\footnotetext{
105 Carne frita, armazenada em caixa d'água, preparada para o almoço de encerramento da Festa de Folia de Reis de Palmital/SP. Foto da autora, Janeiro de 2008.
} 
A festa de encerramento simboliza o encontro dos Reis com o menino Deus. Nela seus rituais e elementos ganham amplitude. Outros rituais são próprios deste momento, como desatar as fitas presas nos arcos - para cada arco transposto, é realizada uma cantoria. É comum, nestes momentos, devotos depositarem pedidos e fitas na Bandeira. Ainda, segundo algumas crenças, algumas pessoas colocam uma fita na Bandeira e retiram outra, que é levada para dar sorte.

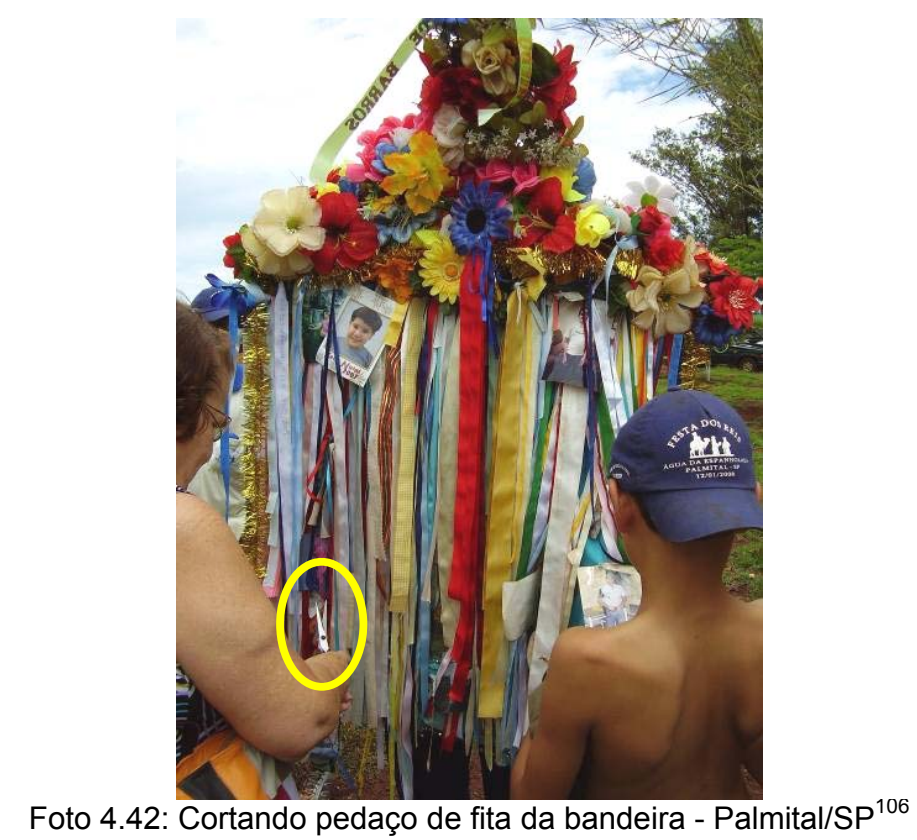

Geralmente, no final do almoço, é realizado um dos rituais de maior emoção para a comunidade: a passagem da Bandeira para o novo festeiro, ou a coroação do novo festeiro. Em todos os momentos da festa, a Bandeira que foi depositada no presépio continua sendo reverenciada por todos os participantes.

[...] avultavam aos bandos, no campo de São Domingos, em alegre algazarra, postando-se nas imediações do amplo quadrado, os rufos das caixas de guerras batidas ao longe.

Esquisitos no trajar, no semblante, nos gestos, negras e negros novos irrompiam de cada lado, entregues à obediência de seus chefes, à vigilância nunca iludida da polícia, que os empreitava.

\footnotetext{
${ }^{106}$ Foto da autora, Janeiro de 2008.
} 
$\mathrm{E}$ os pandeiros, os tambores, as macumbas, os canzás, as marimbas, precedendo a multidão, anunciavam estrugindo a entrada triunfal dos Congos nos festejos profanos da coroação de um Rei. (MORAES FILHO, 1979, p. 227-228).

A queima de fogos é tradicional na chegada da folia, bem como na hora da passagem da coroa. Também é comum acontecerem discursos feitos pelo antigo festeiro, pelo gerente da folia e pelo novo festeiro. Nessas falas são relembradas as origens da folia no grupo e professados os desejos de continuidade. São feitos agradecimentos aos membros da comunidade que se empenharam na realização da festa.

Na região de Ourinhos, a festa de Palmital está inserida no calendário oficial da cidade e é prestigiada por diferentes autoridades. Em 2008 contou com a presença de inúmeros prefeitos, deputados e secretários de Estado. É uma das maiores festas da região; a cidade conta com aproximadamente 21 mil habitantes; em janeiro deste ano, foi calculada pelos organizadores e festeiros a presença de aproximadamente 35 mil pessoas. 

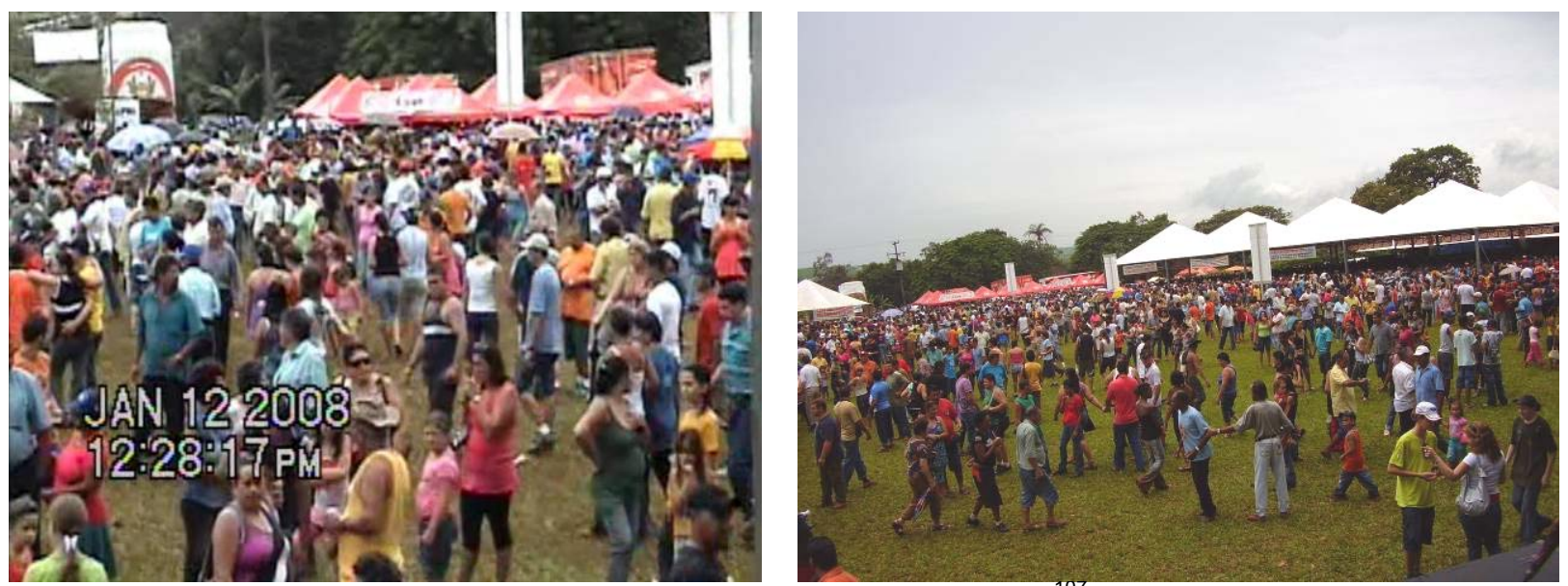

Foto 4.43: Público da Festa de Palmital/SP ${ }^{10}$



Foto 4.44: Estacionamento - Festa de Folia de Reis Palmital/SP ${ }^{108}$

107 Público presente na Festa de Folia de Reis da cidade de Palmital/SP. Fotos da autora, Janeiro de 2008.

${ }^{108}$ Palmital/SP. Foto da autora, Janeiro de 2008. 


\section{O REGISTRO DAS CULTURAS SUBALTERNAS NA ARTE DOS}

\section{ARTISTAS POPULARES}

[...] mas tudo é animado por uma visão estranha e agradável de seu olhar, um sopro de alegria lava as fachadas das igrejas, que são seu principal assunto, ele as pinta das mais berrantes cores, são de ver e não de rezar, vaidosas de aparecer como enfeitadas para festas de rua.

[...]

$\mathrm{O}$ artista bebe na arte a água que a vida lhe nega.

(CELESTINO, Antonio, 1972) $^{109}$

\subsection{O Museu de Arte Primitiva de Assis e sua Arte Desconhecida}

A região abriga, na cidade de Assis, um museu de arte "Museu de Arte Primitiva de Assis José Nazareno Mimessi", que leva o nome de seu fundador, mineiro de Caxambu. Corretor de seguros e imóveis, poeta e autodidata, como pesquisador da Pintura Popular, doou obras de seu acervo para articular o início do museu, fundado em 18 de Outubro de 1982 e regulamentado pela Lei Municipal $n^{\circ} 2.180$.

Hoje o Museu pertence à Fundação Assisense de Cultura "Joshey Leão"; está localizado em um parque ecológico - Parque "João Domingos Coelho", conhecido como Parque do Buracão, na Rua Antônio Zuardi, 895. Funciona em prédio próprio, de $517 \mathrm{~m}^{2}$ de construção, inaugurado em 26 de Setembro de 1999, patrocinado pela empresa Telecomunicações de

\footnotetext{
109 Antonio Celestino, no livro Gente da Terra, da Editora Martins Fontes, 1972. O último capítulo do livro que focaliza o pintor Cardoso e Silva. Cópia datilografada do arquivo de José Nazareno Mimessi, CEDAP, Assis/SP (cópia do documento no anexo C)
} 
São Paulo (Telesp), através da Lei Federal de Incentivo à Cultura. Sua estrutura compõe-se de três salas, duas para exposições temporárias e uma para exposição permanente com obras de seu acervo.

Seu Fundador, Nazareno Mimessi, ao mesmo tempo em que se empenhava para ampliar o acervo, mantinha uma extensa correspondência com pintores, museus, críticos de arte, galerias, marchante e estudiosos de todo o Brasil, documentando a trajetória e vida dos artistas pertencentes ou não ao Museu.

Após sua morte, essas cartas, outros documentos e textos foram doados ao Centro de Documentação e Apoio à Pesquisa (CEDAP), da Universidade Estadual Paulista (UNESP), Campus de Assis. O centro mantém três linhas de pesquisa, complementares: Memória Local e Regional, Cultura e Literatura e Memória Nacional.

No CEDAP, o arquivo de Mimessi encontra-se entre os documentos de Cultura e Literatura e não foi ainda totalmente catalogado. Os documentos estão agrupados em dossiês de artistas. Cada artista possui um envelope que contém cartas trocadas com Nazareno, recortes de jornais, textos de livros pesquisados, cartazes de exposições, folhetos e folders de apresentação, cartões de visitas e outros registros. Os conteúdos usados para subsidiar este texto encontram-se nas trinta pastas já higienizadas e catalogadas, de um montante de aproximadamente noventa caixas do arquivo.

Frente à necessidade da atualidade em compreender o ethos cultural de brasilidade e da arte do povo, bem como compreender as dinâmicas da constituição imagética das festas estudadas, necessárias para constituir um referencial teórico que subsidie o entendimento da dinâmica das sociedades 
vinculadas ao popular na atualidade, surgiu o interesse em compreender as manifestações plásticas dos pertencentes às culturas populares e tê-las como fonte de conhecimento e informação para avaliar como sobrevivem, processam-se e recriam-se as formas comunicacionais e estéticas da cultura subalterna.

Igualmente, é preciso depreender esforços, no sentido de estudar e valorizar as manifestações portadoras do ideário e das tradições que remontam à formação da cultura brasileira, presentes nas obras dos artistas do Museu, detentor de um acervo de 1.300 peças.

Compreender, portanto, as manifestações plásticas do museu como fontes e registros iconográficos das culturas populares é uma forma de conhecer os mecanismos que permitiram e permitem a conservação, a adaptação e a hibridização das tradições mantidas nas festas que se realizam no país e na região estudada.

As comunidades que se formaram e se estruturaram, a partir das primeiras décadas do séc. $\mathrm{XX}$, são portadoras, em sua origem, de elementos próprios da cultura de massa que emergia no mesmo período. Isso contribuiu para que nessas comunidades se desenvolvesse um modo vivente de não preservação da memória, aceitação imediata do novo, inserção na sociedade de consumo e a desconstrução do existente em favor do moderno.

No espaço de aproximadamente setenta anos, os núcleos urbanos da região e a dinâmica rural existente foram totalmente alterados e muito do patrimônio histórico, cultural, material e imaterial, desapareceu ou acompanhou e incorporou as dinâmicas que constituem e caracterizam a sociedade emergente. As manifestações culturais que caracterizam o cotidiano 
passaram a ser, portanto, fontes de pesquisa e preservação da cultura

brasileira. Os acervos de Assis - Museu e CEDAP - podem ser incluídos como

representantes da cultura acadêmica, mas se transformam, nesta ótica, em um

legado fundamental para a compreensão da identidade das culturas populares

do país.

$\mathrm{Na}$ análise das manifestações plásticas do Museu, fez-se

necessário recorrer novamente ao pensamento gramsciano, visto que nele é possível ancorar uma conceituação capaz de embasar teoricamente uma área de estudo carente de debates, já que, nos meios acadêmicos, ainda são poucos os estudos relativos às artes populares. As sustentações teóricas são dicotômicas e têm como ponto da partida a arte erudita, ou as manifestações contemporâneas. O pensamento gramsciano aponta que:

[...] Pode-se dizer que, até agora, o folclore foi preponderantemente estudado como elemento "pitoresco" (na realidade, até agora, foi apenas coletado material de erudição, e a ciência do folclore consistiu, sobretudo, no estudo sobre o método para coleta, seleção e classificação desse material) [...] Seria preciso estudar o folclore, ao contrário, como "concepção do mundo e da vida", em grande medida implícita, de determinados estratos (determinados no tempo e no espaço) da sociedade, em contraposição [...] às concepções do mundo "oficiais", ([...] o folclore filosófico.)[...]

[...] só pode ser compreendido como um reflexo das condições de vida cultural do povo, ainda que certas concepções próprias do folclore ou perdurem mesmo depois que as condições foram (ou pareçam ter sido) modificadas ou, então, dêem lugar a combinações bizarras.

[...] É verdade, assim, que existe uma "moral do povo", entendida como um conjunto determinado (no tempo e no espaço) de máximas para a conduta prática e de costumes que delas derivam ou que as produziram; moral que é estritamente ligada, tal como a superstição, às reais crenças religiosas: existem imperativos que são mais fortes, persistentes e efetivos do que os da "moral" oficial. Também nesta esfera devem-se distinguir diversos estratos: os fossilizados, que refletem condições de vida passadas e que são, portanto, conservadores e reacionários; e os que são uma série de inovações, frequentemente criadoras e progressistas, determinadas espontaneamente por formas e condições de vida em processo de desenvolvimento, e que estão em contradição com a moral dos estratos dirigentes, ou são apenas diferentes delas. [...]

[...] Portanto, conhecer o folclore significa, para o professor, conhecer quais são as outras concepções do mundo e da vida que atuam de fato na formação intelectual e moral das gerações mais jovens [...] $O$ folclore não deve ser concebido como uma bizarria, mas como algo 
muito sério e que deve ser levado a sério. Somente assim, o ensino será mais eficiente e determinará realmente o nascimento de uma nova cultura entre as grandes massas populares, isto é, desaparecerá a separação entre cultura moderna e cultura popular ou folclore. Uma atividade deste gênero, feita em profundidade, corresponderia no plano intelectual ao que foi a Reforma nos países protestantes. (GRAMSCI, 2002, p. 133-136). ${ }^{110}$

Nesse capítulo, as conceituações de Canclini (1983) também serão relevantes para subsidiar as considerações elaboradas sobre arte popular. Em seu livro As culturas populares no capitalismo, defende o uso do termo culturas populares por serem as manifestações que caracterizam as diferentes comunidades que constituem as camadas subalternas e utiliza 0 conceito de subalternidade quando analisa as produções populares que se mostram em oposição às proposições das culturas hegemônicas.

Para o autor, as culturas populares derivam "também do fato de que o povo produz no trabalho e na vida formas específicas de representação, produção, reprodução e reelaboração simbólica." Canclini (1983)

As Artes das culturas populares, compreendidas como cultura subalterna, não podem ser vistas somente como "exóticas", nem como produto para turista; tampouco, como produto das feiras de artesanato sujeitas ao gosto e modismo do mercado: devem ser vistas e compreendidas por elas mesmas como uma categoria de arte.

Mais um fator que deve ser notado é que não são imutáveis ou estáticas; acompanham a própria evolução das comunidades e registram os valores de sua formação. Nos estudos elaborados, foi constatado o uso de

\footnotetext{
110 Os fragmentos do texto apresentado remetem para a idéia de "folclore" como o "fazer" das classes subalternas e, como as manifestações plásticas do Museu são fazeres representantes dos provenientes das classes populares, Gramsci aponta como é importante compreender e valorizar este "fazer" esta arte. Este trecho encontra-se no Caderno 27 (1935): Observações sobre o "folclore", volume 6, da coleção Cadernos do Cárcere, onde são apresentados seus textos sobre literatura e folclore.
} 
conceitos e de fundamentações teóricas e críticas que se contradizem, que esvaziam ou simplificam as conceituações das artes provenientes das camadas populares do povo brasileiro, sujeitas a muitas denominações e definições.

As manifestações plásticas das culturas populares nascem paralelas às muitas outras manifestações culturais geradas pelos diferentes grupos que as constituem e são o espelho dos conflitos e tensões nos quais estiveram mergulhadas, durante sua formação. $\mathrm{Na}$ atualidade, explicitam tensões entre serem atuais, globais, e manterem suas matrizes de origem e autenticidade.

\begin{abstract}
Nesse espaço conflitivo e adaptativo, a cultura subalterna refuncionaliza as mensagens recebidas, adaptando-as ao seu cotidiano. Daí resulta que as classes subalternas estruturam o seu mundo a partir de uma coexistência não harmoniosa, mas nem sempre conflitiva, com outras culturas e ideologias. Como resultado desse exercício de sobrevivência, a cultura das classes subalternas não é homogênea, pois nela convive a influência das classes hegemônicas e dos valores civilizatórios ancestrais [...] (FERREIRA, 1995, p.25).
\end{abstract}

Os acervos de Assis - as pinturas do museu e as documentações do CEDAP - se transformam, nesta ótica, em um legado fundamental para a compreensão das artes produzidas pelas camadas populares subalternas, bem como do imaginário e da identidade nacional por elas gerados e gestados. Impõem aos pesquisadores uma problemática crucial: como manter-se fiel a essas produções e manter-se fiel aos seus protagonistas e produtores.

Para alcançar esses objetivos e compreender como esses acervos foram edificados, se fez necessário analisar sua origem, assim como foi imprescindível fazer aflorar o pensamento de seus edificadores fundadores e pintores. As transcrições abaixo procuram atender a esses 
propósitos em que o pensamento e as falas dos protagonistas serviram como base para sustentar as argumentações propostas.

Um dos primeiros documentos analisados foi um livro sobre

pinturas escrito por Mimessi; nele, o autor se apresenta da seguinte forma:

José Nazareno Mimessi, nascido em Caxambu, MG, em 12 de março de 1925, corretor de seguros e de imóveis, poeta bissexto, pesquisador da Pintura Primitiva Brasileira, criador, juntamente com Maria Cândida Godoy Kobori, do projeto cultural 'Trem das Duas', 'descobridor' do pintor primitivo assisense Ranchinho (Sebastião Theodoro Paulino da Silva), e fundador do Museu de Arte Primitiva de Assis, conhecido como Museu de Pintura Primitiva de Assis. Escreveu três livros: Pintura Primitiva (Naïve) - Resultados de uma pesquisa; e dois ainda inéditos: José Antonio da Silva, o pintor primitivo de nosso sertão e Ranchinho, o pintor primitivo de Assis (MIMESSI, 1991).

Ainda no mesmo livro, aparecem, no posfácio, as seguintes

observações:

Depois de ter conduzido esta pesquisa por longos anos, razões particulares e relevantes levaram-me a desejar ver editado este livro dentro de breve tempo.

Isso explica alguns senões que possam ser notados dos quais pedimos excusas, julgando que o leitor saberá desculpar-nos, dando ênfase ao nosso esforço e ao nosso empenho.

Por estes mesmos motivos não foi possível a revisão dos nomes próprios, sendo que alguns foram escritos com todas as letras em maiúsculas, enquanto outros somente com a letra inicial, não implicando tal fato em se atribuir maior ou menor importância às pessoas citadas ou referidas.

Edição do autor. Direitos reservados.

$1^{\mathrm{a}}$ Edição.

Número de exemplares editados: 500 (quinhentos)

Observação:

Edita-se este livro às expensas nossas, não tendo se beneficiado de patrocinadores ou de recursos de nenhuma instituição ou fonte. (MIMESSI, 1991)

Nos documentos analisados no CEDAP encontra-se o catálogo comemorativo do $2^{\circ}$ aniversário do Museu, no qual Mimessi fornece dados para elaborar uma visão do propósito de sua criação e da representatividade de sua coleção: José Nazareno Mimessi, pesquisador da pintura primitiva brasileira (Naïve), que fez doação do acervo de 204 obras de arte, com as 
quais se inaugurou o Museu.

Sua criação foi oficializada pela Lei $n^{\circ}$. 2.180 , de 18 de outubro de 1982, pelo prefeito Lauro Spera, durante a gestão de Dra. Edna Maria de Carvalho na Coordenadoria de Educação e Cultura.

Para que a idéia de sua criação viesse a se concretizar, contamos com a colaboração especial de Liliana Miguel Longo e Dr. Ricardo Siloto da Silva.

Neste momento em que se lança o catálogo comemorativo do $2^{\circ}$ aniversário do nosso Museu, vê-se que nossas lutas não foram em vão. Os números expostos, por si só, o dizem.

No dia de sua Inauguração, assim era composto o seu acervo:

Número de artistas - 82

Número de obras de arte -204

Passado um ano após a Inauguração, o acervo já atingia os seguintes números: de artistas - 222; de obras de arte -840

Esses números - motivo de nosso orgulho - traduzem a confiança do povo de Assis, dos Órgãos de Imprensa, dos Colecionadores, dos Poderes Públicos, dos Estudiosos da Arte e, em especial, daqueles muitos artistas primitivos que - no mais das vezes sem nos conhecer - tem prestado generosa solidariedade, presenteando nossa cidade com importantes e valiosas doações.

Esse crédito de confiança, que nos levou a tão expressivos resultados, leva-nos agora a não parar; leva-nos a prosseguir; levanos a avançar mais. [...]

O MUSEU DE PINTURA PRIMITIVA DE ASSIS empreende agora novo passo, vence nova etapa na consecução de seus planos: a exposição das obras de arte de seu acervo em vários pontos da cidade.

Os primeiros passos já foram dados nesse sentido.

Quadros de nossos primitivos já se encontram nos mais diversos locais de Assis: Banco Comind S/A; Banco do Brasil S/A; Banco do Estado de São Paulo S/A; Café Viena; Instituto de Letras, História e Psicologia de Assis; Instituto Nacional de Previdência Social; Departamento dos Correios e Telégrafos; Hotel São Francisco; Prefeitura Municipal de Assis.

Desta forma, pouco a pouco, Assis se torna a maior vitrine artísticoprimitiva do Brasil.

Levando-se em conta que a cidade de Assis é possuidora do mais importante Museu de Pintores Primitivos Brasileiros; do mais completo arquivo focalizando esses artistas; e, afinal, considerando estar implantado este importante plano de semear mini-museus primitivos nos mais diversos recantos de nossa terra, [...]

No intuito de oferecer aos estudiosos e aficcionados da Arte propostas de múltiplas espécies, nosso Museu passou a formar acervo dos seguintes ramos artísticos:

Arte Infanto-Juvenil

Bonecos

Brinquedos Artesanais

Esculturas

Maquetes Artísticas

Máscaras

Presépios

Tapeçarias

e dando início também a uma

Biblioteca. (MIMESSI, 1985, grifos da autora). 
ilustrar o que se propõe neste capítulo, pois é um objeto representativo do espaço conflitivo onde as artes populares brasileiras estão inseridas. Nele, o autor explicita o esforço para criar, demonstrar e valorizar as pinturas populares e, para atingir seu objetivo, busca a aprovação e a apreciação dos setores hegemônicos da sociedade onde está inserido - como as exposições elaboradas para essa divulgação em bancos e outros setores da sociedade dominante. Também, ao transcrever a opinião de Pietro Maria Bardi, então diretor e curador do Museu de Arte de São Paulo (MASP), torna-se clara sua procura por uma aprovação e aceitação dos setores hegemônicos e eruditos da preservação e gestão das artes no país. Portanto, no mesmo catálogo, Mimessi (1985) transcreve artigos de Pietro Maria Bardi (1900-1999), então diretor do MASP, e de Walmir Ayala (1933-1991), crítico de arte.

Outra entidade a ser citada no interior do Estado de São Paulo é o Museu de Pintura Primitiva de Assis, inaugurado em janeiro último pela Prefeitura local, formado basicamente com obras doadas pelo pesquisador de arte ingênua, José Nazareno Mimessi, daquela cidade. $\mathrm{O}$ abnegado doador, responsável também pela divulgação do museu em outros centros, abriu mão de mais de 200 peças e do rico acervo que possuía para dar vida à instituição, colocando as peças à disposição do público e de pesquisadores. Fazem parte do acervo quadros de José Antonio da Silva, Agostinho Batista de Freitas, Chico da Silva, Crisaldo Morais, Eli Heil, Maria Auxiliadora e muitos outros. Além disso, o museu apresenta uma sala especial dedicada ao artista Ranchinho, natural de Assis, que pintou cenas da cidade e da região. As iniciativas de Assis e de Mococa são exemplares e gratificantes para os que lidam com a arte e a cultura. (BARDI, 1983, p. 85).

Mantenho há alguns anos um diálogo epistolar com José Nazareno Mimessi, um abnegado pesquisador da cidade de Assis, no Estado de São Paulo. São contatos espaçados, mas que me fizeram admirar este homem simples e dedicado, que se empenha num levantamento nacional da pintura ingênua e primitiva brasileira, o que hoje tem, sem dúvida, um dos melhores arquivos no gênero.

No decorrer dos anos ele foi levantando biografias, extraindo depoimentos, recorrendo incansavelmente a todas as fontes cabíveis, e pode-se dizer que ostenta, hoje, a integridade de uma obra, coisa que só os imbuídos dos sentidos de missão lograram alcançar.

O material reunido por José Nazareno, nome que a meu ver sublima primorosamente sua pessoa integral, o homem e o estudioso, certamente daria um alentado volume de arte primitiva dicionarizada. Agora José Nazareno Mimessi doou parte do acervo que vem reunindo anos a fio à Prefeitura Municipal de Assis, através de sua 
Coordenadoria de Educação e Cultura, e, com isso, a administração sensível e construtiva, liderada por Edna Maria de Carvalho, fez inaugurar o Museu de Pintura Primitiva de Assis. Como uma bola de neve, todo o trabalho apaixonado e desprendido de José Nazareno, encontra eco e se institui em obra perene e altamente louvável. Foram doadas para a composição inicial do Museu 100 obras de Ranchinho e mais obras de Chico da Silva, Crisaldo Morais, Eli Heil, Elza O. S., Gerson, Iaponi, Isabel de Jesus, Ivonaldo, Maria do Santíssimo, Miriam, Omar Souto, entre muitos outros. Ao todo, 204 trabalhos.

Este Museu merece a atenção e o apoio de todos. Artistas ingênuos e primitivos de todo país têm a oportunidade de entender e fazer-se presentes em seu espaço. O Museu de Pintura Primitiva de Assis tem o seguinte endereço: Praça Nicolau Carpentieri, Assis, Estado de São Paulo. (AYALA, 1983).

Mimessi transformou-se em um autodidata extremamente interessado e apaixonado, manteve uma extensa correspondência com pintores, museus, críticos de arte, galerias, marchantes e estudiosos de todo Brasil, documentando a trajetória e vida dos artistas pertencentes ou não ao Museu. Esses documentos são valiosas fontes para se compreender como pensam os artistas das classes populares subalternas, quais as relações que possuem com a cultura hegemônica, como efetuam a leitura do seu entorno e, principalmente, como compreendem a arte erudita e de vanguarda. Acima de tudo, é possível ver nesses relatos o percurso dos seus processos criativos e, principalmente, como definem suas criações.

As transcrições abaixo são os resultados das leituras do material disponível para consulta no CEDAP. O arquivo de Nazareno, ainda não foi todo higienizado, nem microfilmado. Os dados foram obtidos em pesquisa local e através de cópias xerográficas, autorizadas pelo Centro. Dentre o material pesquisado, as citações abaixo explicitam como os artistas desconhecidos do grande público e dos círculos hegemônicos de difusão das artes- pensam a cultura brasileira, sua visão de mundo e sua própria consciência de como definem e encaram seus trabalhos. Os grifos nos textos 
selecionados foram feitos para destacar o pensamento e a visão de mundo, de arte e a própria forma como os artistas populares se vêem e compreendem

seus trabalhos; portanto, a extensão das citações se fez necessária para que, neste trabalho, a voz dos artistas populares subalternos se fizesse presente.

[...] Se um dia descredes da sorte do Brasil e 'apagada a vil tristeza' baixar sobre vossas cabeças o melancólico patriota não desespereis porque alguém conhece a senha do sucesso e da glória.

Se num dia de nostálgica raiva literária descobrirdes que o soneto morreu, talvez assassinado por gente da terra e que não há mais sonetistas,[...]

Se quiserdes saber por que o astrolábio é um aparelho muito apropriado para imagens de poetas esotéricos, se alguma dúvida vos moer a inteligência por causa da influência dos mares no comportamento da seiva das árvores, [...] se não jurares sobre a fidelidade de Cromwell para com seu Rei, se não sabeis por que a alma é imortal, [...] se quereis saber com exata verdade o motivo porque vos enganaram os que afirmam que o homem já esteve na lua, se animardes vossa recôndita ânsia de saber o futuro pelas estrelas, não deveis vos preocupar, pois as respostas talvez estejam ao vosso lado, se ao vosso lado estiver CARDOSO E SILVA, pintor, poeta e mágico.

Figura das mais curiosas desta terra de tão diferentes tipos humanos, [...] dono da mais desconcertante gargalhada humana, enciclopédico, viajado à roda do seu quarto, agricultor de terras áridas que cultiva numa paisagem de cabras montesas, íntimo de Deuses, [...] conselheiro de sábios desencarnados, [...] Sua vida é para além das misérias da carne, ele a sustenta num plano de invenção e de Nirvana, assim vai deixando que a terra corra debaixo de seus pés, ele se mantém suspenso pelo fio inconsútil duma delirante imaginação.

E é por via dela que sua pintura simples e ingênua tem interesse. [...] mas tudo é animado por uma visão estranha e agradável de seu olhar, um sopro de alegria lava as fachadas das igrejas, que são seu principal assunto, ele as pinta das mais berrantes cores, são de ver e não de rezar, vaidosas de aparecer como enfeitadas para festas de rua.

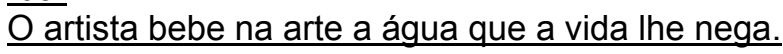

Dela tira seu sustento de alegria e de paz. (CELESTINO, 1972) $)^{111}$

No último dia doze, encerrou-se na galeria de arte do SENAC, a exposição do pintor Redencense, Toninho Mendes, conhecido por todos nós, pela seriedade de seu trabalho e, principalmente, por retratar em suas obras, nosso vasto folclore e a riqueza dos folguedos e festas populares [...]

[...] Nas festas era comum a apresentação de congadas, folias, mocambique e muitas outras coisas que foram desaparecendo, creio que pelo descaso das autoridades em geral, que não se interessam, talvez até por falta de visão maior em relacão a isso.[...]

Nas festas religiosas de sua época, não faltavam, para o povo, o café

111 Trecho de documento do arquivo de José Nazareno Mimessi, CEDAP, Assis/SP. Vide nota 136. (Íntegra do documento no Anexo C). Grifos da autora. 
com biscoito e o tradicional afogado. 'Para mim, festa que não tem alguma coisa para o povo comer, não tem muito sentido, [...]

Toninho, além do grande pintor que é, dá também suas investidas no campo das letras - 'estou escrevendo um documentário, sobre as festas e alguns casos pitorescos da época [...].

Jornal de Boas Notícias de Redenção da Serra.

"Taubaté mostra, no Pilar, a arte das figureiras da Imaculada.

As figuras de barro, símbolo do artesanato paulista, hoje, são admiradas em todo o mundo.

Consideradas como modelo do artesanato paulista, as figuras de barro das artistas da Imaculada ultrapassaram fronteiras e hoje são admiradas em diversos países, principalmente da Europa. Cândida, uma das expositoras, venceu o concurso da Secretaria do Trabalho para escolha da peça símbolo do artesanato paulista. Seu pavão foi o escolhido."

Jornal Vale Paraibano de 9 de dezembro de 1981, p. 8.

\section{"Climério Cordeiro}

[...] seus quadros são sínteses do passado no presente, os sonhos infantis projetados no mundo adulto, Climério alcança os mitos universais, a interação primitiva do homem com a natureza.

- SARAVÁ OGUM -

São Bernardo do Campo, 07 de outubro de 1981

ZÉ CORDEIRO"

Climério mostra uma pintura de profundas raízes populares, que reflete a vida simples de nossa gente, do sertanejo, deste povo que, segundo Jorge Amado, surgiu 'do amor profundo das raças que se encontram em nosso solo, criando um povo de mestiços, uma cultura mestiça, capaz de resistência a todas as desgraças e de continuar a viver e lutar'.[...]

Enock Sacramento

Membro da APCA - Associação Paulista de Críticos de Arte ARTE/CRÍTICA

Diário do Grande ABC, 5/10/1982.

"Taubaté, 28 de fevereiro de 1984.

Prezado amigo José Nazareno

É com muito prazer que Ihe escrevo para agradecer a valiosa colaboração para comigo, e aproveito-lhe para enviar-lhe meu histórico relacionado à minha carreira artística.

[...] Assim que chegávamos da escola, eu e meu irmão Benedito, momentos depois, iniciávamos nos afazeres das figuras juntamente com minha Mãe e à tarde com a chegada de meu Pai depois de encerrar seu expediente no Correio, também preparava para trabalhar nos acabamentos de pintura indo até altas horas da noite. $\mathrm{E}$ assim prosseguíamos todos os dias os mesmos trabalhos e após alguns meses as prateleiras, mesas e até mesmo o chão estavam 
repletos de figuras ${ }^{112}$ já prontas e pintadas para serem vendidas. Aos sábados e domingos eu as vendia no Mercado Municipal, também na loja do saudoso Sr. Leontino Rosa podiam-se encontrar as nossas figuras, algumas pessoas compravam para vender em outras cidades vizinhas, enfim, nossos trabalhos artísticos espalhavam-se por diversos lugares e eram bem aceitos.

[...] Aos dezoito anos, eu já exercia profissionalmente a pintura predial. [...]

Em 1966 fiz um curso de desenho artístico por correspondência na Escola Dom Bosco Reunidas de São Paulo.

[...] aprendido algumas técnicas, começava a pintar paisagens, mas eu notava que em matéria de figuras eu pouco desenvolvia... E foi nesse ano de 1966 que eu conheci o artista plástico Justino que nessa época trabalhava na Editora Forma em São Paulo e, nessa editora, ilustrou a coleção de Dostoievski.

[...] Em 1967, com a volta de Justino à Redenção, para mim foi um ano marcante, pois recebi dele muita orientação e algumas aulas.

Em 1969 fui por ele convidado a trabalhar na Catedral de Bragança Paulista, SP, onde Justino executou aproximadamente $400 \mathrm{~m} 2 \mathrm{de}$ murais representando a Via Sacra [...]

Justino é um pintor impressionista [...]

O tempo foi passando eu continuava a pintar, mas ainda não tinha um estilo definido [...] um dia resolvi pintar um quadro ao meu modo e saiu um primitivo [...]

Foi em 1974 que realmente defini meu próprio estilo, o primitivo [...]

Atualmente continuo pintando, fazendo figuras em argila [...]

Para finalizar, mais uma vez aproveito para enviar-lhe meus sinceros agradecimentos a você pelo magnífico trabalho que vem se empenhando em prol da arte primitiva e da cultura brasileira.

Antonio da Silva

(grifos da autora)

Mimessi, em seu livro, deixa transparecer como as

fundamentações teóricas existentes não suprem a enorme dificuldade que os teóricos e críticos têm para pensar e conceituar as artes das camadas populares subalternas. Em seu texto foi encontrada uma curiosa árvore genealógica das "Denominações da Pintura Primitiva, segundo diversos autores"; esse trabalho reflete como as pinturas e as outras formas de representações das artes das camadas subalternas são carentes de fundamentações, análises e estudos.

\footnotetext{
${ }^{112}$ As figuras moldadas, segundo o relato na carta do artista, eram presépios.
} 
A impressão que transparece do seu levantamento é a falta de um quadro teórico que dê credibilidade ou ampare, convincentemente, essas manifestações. Os termos levantados por Mimessi são genéricos, muitas vezes sem sentido, ou emprestados de outras ciências; neles, transparecem uma polarização dicotômica - ainda encontrada na atualidade - que empurra as artes das camadas populares para os anexos dos livros, para as indicações complementares; o que não ocorre com as artes dos meios hegemônicos ou quando o assunto são as artes denominadas eruditas.

Inúmeros encontros, congressos e simpósios são realizados para apresentar e discutir fundamentações teóricas que amparem as artes dos artistas dos grandes circuitos acadêmicos e hegemônicos. No texto, são elencadas por Mimessi 52 denominações para definir as pinturas e os artistas do museu fundado por ele.

Pintores Ingênuos, Pintores Naifs, Pintores do Coração Sagrado, Pintores do Instinto e do Coração, Pintores Primitivos Eruditos, Pintores Mestres da Realidade Popular, Pintores do Povo, Pintores Autodidatas, Pintores Ínsitos, Pintores Puros, Pintores Naifs Folclóricos, Pintores Espontâneos, Pintores Intuitivos, Pintores Primitivos Mestres Naifs, Pintores Kitsch, Pintores Populares, Pintores Naifs Eruditos, Pintores Populistas, Pintores de Arte Natural, Pintores Primitivos de Hoje, Pintores Regionalistas, Pintores Sem Estudo, Pintores Primitivos Derivados, Pintores Naturais, Pintores Domingueiros, Pintores Primitivos Testemunho, Pintores Caipiras, Pintores Não Escolarizados, Pintores Incomuns, Pintores Folclóricos, Pintores Não Educados, Pintores Primitivos Modernos, Pintores do Imediato, Pintores Neo Primitivos, Pintores Primários, Pintores Rústicos, Pintores Primitivos Contemporâneos, Pintores Leigos, Pintores Caboclos, Pintores Democráticos, Pintores Instintivos, Pintores Improvisadores, Pintores Inatos, Pintores Naívos, Pintores Mestres Populares da Realidade, Pintores Primitivos Folclóricos, Pintores da Semana dos Sete Domingos, Pintores Primitivistas e Pintores Primitivos. (MIMESSI, 1991, p.1).

Como demonstrou Mimessi, essa não é uma tarefa simples.

Alguns estudiosos em diferentes momentos da evolução cultural do país e do 
mundo se propuseram a encontrar uma fundamentação satisfatória para a produção e para os produtores das artes das camadas populares subalternas.

\title{
5.2 Apontamentos sobre Teorias para as Artes Populares
}

Em seus estudos, Rossini Tavares de Lima e Julieta de Andrade apontam diferentes classificações para o fazer dos artistas populares como: arte folclórica, artesanato folclórico, e ainda conceitos de cultura letrada, para cultura erudita e pré-letrada que coexistem com a arte folclórica, popularesca e primitivista, também chamada por eles de neoprimitiva, ingênua, e ínsita (do latim insitos, inato).

Pinho também recorre a diferentes conceitos para analisar o mercado de arte e a importância dada pelos consumidores ao que denomina de:

\begin{abstract}
[...] arte ingênua, ou arte naive (art naïf), kitsch, art brut - esta última distinguindo-se das demais por seus autores serem considerados 'mental e/ ou socialmente marginalizados'; os trabalhos são concebidos e executados fora do campo de 'belas' - artes, como as que são produzidas pelas crianças, os loucos e os primitivos. (PINHO, 1988, p.51)
\end{abstract}

A autora cita, ainda, os pintores que reproduzem um padrão estético muito próximo dos artistas oriundos das camadas populares, aqueles que trabalham de modo artesanal, chegando à escala industrial, para a venda de quadros a grandes lojas ou shopping centers, reproduzindo o mesmo tema centenas de vezes, ou os que fazem quadros heterogêneos e ecléticos, baseando-se em cópias, para o grande público, como: salas de espera de aeroportos, hospitais, clínicas de atendimento à saúde, entradas de faculdades, 
salões de chá, clubes de campo, bancos, feiras de arte-artesanato, e que também podem ser comercializados em ruas de grande movimento - os quadros que combinam com a cor do sofá.

O historiador e pesquisador de arte popular brasileira, Eduardo Etzel (1975, p.15), refere-se a estas produções como: arte ingênua, arte primitiva, primitivo moderno, neoprimitivismo, arte popular, arte popularesca e arte folclórica, não diferindo muito das proposições de Mimessi.

Do mesmo modo, Arnold Hauser, em seu livro Teorias das Artes, também construiu seus argumentos sempre comparando as manifestações artísticas e culturais como se fossem compartimentos isolados em oposição permanente, "[...] arte folclórica significa as atividades poéticas, musicais e pictóricas dos estratos da população que não são cultos nem urbanizados ou industrializados". (HAUSER, 1998, p. 243). A linha de pensamento de Hauser está muito distante da realidade atual, em que as culturas transitam em todas as esferas e o espaço rural e urbano foram diluídos.

Outros autores também recorreram a várias nomenclaturas para explicitarem suas conclusões acerca da arte e, principalmente, da arte popular brasileira, desvinculada de correntes estilísticas dos círculos vanguardistas ou hegemônicos.

Nesta perspectiva, os estudos ainda são recentes, mesmo após os caminhos abertos pelos modernistas e os teóricos que surgiram pósSemana de 22 que implementaram as pesquisas sobre as manifestações populares. 
Mário de Andrade apud Avancini (1992) reuniu, no conjunto dos vinte volumes que compõem suas Obras Completas, nove relacionados a críticas das artes, mantendo sempre uma unidade de propósito na busca de conceitos de uma arte brasileira, sua origem e uma constante "busca das fontes populares e folclóricas que alimentavam e enriqueciam a arte culta e moderna produzida pelos modernistas". (ANDRADE apud Avancini, 1992, p. 93).

Mário elaborou uma crítica seletiva, configurada pela busca histórica, que justificasse a produção de sua época e a delimitação de seu caráter nacionalista; elaborou um trabalho de apaixonado que Ihe possibilitou reescrever seus conceitos, sempre utilizando várias abordagens, para explicar o fenômeno e o objeto artístico das artes produzidas pelo povo. Antonio Cândido, Sérgio Milliete e Câmara Cascudo também o fizeram.

Outro apaixonado pela cultura brasileira que buscou compreender as tramas híbridas e as inúmeras produções artísticas do país foi o francês Roger Bastide, descrito por Rui Coelho, em depoimento prestado a Melo e Silva (1991):

Bastide afirmava que não havia 'para-literatura', pois nada está fora da literatura. Buscava, sempre, uma visão dinâmica do fato estético, elaborando os princípios do que seria uma Teoria das Mutações, sua grande contribuição teórica, subjacente aos escritos brasileiros, não se preocupando em definir se o que fazia era sociologia, antropologia ou psicologia social. Era mais um especialista em sociologia da criatividade, buscando a base da produção artística, usando para isso indistintamente as disciplinas que necessitasse, fosse a sociologia ou a antropologia.

Procurava penetrar a obra de arte como 'forma de vida' do 'outro'. Tinha uma habilidade incrível para ouvir as pessoas e delas retirar as idéias, a direção intelectual, numa atitude de profundo respeito pelo outro, querendo conhecer esse 'outro'. (SILVA, 1991, p. 93, grifos da autora).

$\mathrm{Na}$ atualidade, o conceito de cultura subalterna de Gramsci

pode ser um caminho a seguir nesse emaranhado de definições e é, por certo, 
o que mais atende à necessidade de não classificar ou usar artifícios de polarização, como arte erudita $\mathrm{x}$ arte popular, artes dos meios midiáticos $\mathrm{x}$ arte folclórica. A própria denominação - manifestação folclórica - necessita de argumentações para fazer-se entender na atualidade. A contribuição gramisciana para essa dicotomia pode ser compreendida na citação abaixo, segundo Madríz apud Ferreira (1997):

Gramsci parte dos conceitos elitistas que define cultura como saber enciclopédico, atividade especulativa reservada aos grandes talentos e circunscrita ao campo artístico e educativo. A partir daí, constrói um conceito dinâmico e historicista, no qual a cultura é compreendida como um processo que se conserva e se renova, permanentemente, na prática social. Esta ótica amplia 0 sujeito produtor/receptor/consumidor de cultura a todo o universo social.

Por outro lado, aponta a necessidade da superação de um estado de cultura existente para um dever ser cultural, [...] Estes cenários de confrontação com os lugares do povo, aqui definidos, a partir de categorias de classe, como um conjunto das classes subalternas e instrumentais que existem em todos os tipos de sociedade atuais [...] Sempre que o sujeito social, o povo, se define por oposição às classes hegemônicas, a cultura se define pela mesma oposição àquilo que é oficial pertencente à elite dominante [...] (FERREIRA, 1997, p. 29).

Ferreira aponta que o subalterno será considerado como conceito policlassista que se adapta e se ressignifica no movimento dos sistemas através de seus próprios meios de comunicação: ele gera uma forma própria de assimilar e consumir as informações impostas pelos meios massivos, assim como gesta seu próprio meio de comunicação.

Sob este prisma, na sociedade globalizada, o estudo das culturas populares subalternas possibilita compreender a identidade cultural e a construção simbólica que dão sentido às representações materiais a elas pertencentes que, por sua vez, provocam uma circularidade em todas as manifestações culturais.

Os ensinamentos e perspectivas teóricas dos pesquisadores da primeira metade do século passado apontam subsídios para analisar e 
responder às inquietações do presente, como o faz Gramsci, mas não esgotam todas as respostas. Assim: como compor um quadro teórico que utilize os princípios gramscianos de culturas das classes subalternas hegemônicas com a realidade caótica das produções artísticas de nossa contemporaneidade? Esta indagação está presente neste tópico, e, se não é possível respondê-la prontamente, pretende-se apontar para possíveis caminhos e estudar as artes das culturas subalternas como Categoria de Arte ou estudá-las, por elas mesmas, dentro da linguagem das artes visuais. Citando Mário de Andrade: "A humanidade carece de rótulos para compreender as coisas. Falando de modo geral, a humanidade não compreende as coisas, compreende os rótulos." (apud MORAES, 1978).

A complexidade e a polarização da sociedade contemporânea produzem um discurso polissêmico nos meios acadêmicos, exigindo esforços constantes para conceituar com clareza as artes populares. O domínio das novas tecnologias e os avanços nos processos comunicacionais do nosso tempo não apagaram as origens de nossa formação cultural, que se recria como um organismo vivo, sem perder sua essência. Santaella (2004) apresenta uma divisão da cultura em seis eras: a da cultura oral, escrita, impressa, de massa, das mídias e a digital. Explica, ainda, que a cultura das mídias não pode ser confundida como cultura de massa e nem como cultura digital; situa-se como uma cultura intermediária:

[...] quer dizer, a cultura digital não brotou diretamente da cultura de massa, mas foi sendo semeada por processos de produção, distribuição e consumo comunicacionais a que chamo de 'cultura das mídias'. Esses processos são distintos da lógica massiva e vieram fertilizando gradativamente o terreno sócio-cultural para o surgimento da cultura digital ora em curso. (SANTAELLA, 2004, p.13). 
O ciber-mundo, ao mesmo tempo em que interligou e conectou todos os viventes - mesmo os que se encontram em relativo isolamento também está forçando as múltiplas sociedades a explicitar escolhas e opiniões, levando a comunidade acadêmica a conviver com as mais diferentes abordagens das ciências para explicar o mundo atual.

No entender de Santaella, urge elaborar-se uma nova teoria capaz de explicar o mundo real; sendo assim, recorre-se às ciências disponíveis e a diferentes correntes teóricas, num movimento de reinterpretação constante, criando um processo cumulativo e complexo de conceituações que ainda não conseguiram abordar satisfatoriamente as manifestações das culturas populares.

Outro aspecto a ser explicitado diz respeito ao fato de que, não obstante, as divisões acima indicadas das seis eras culturais refiramse, de fato, a eras, prefiro também chamá-las de formações culturais para transmitir a idéia de que não se trata aí de períodos culturais lineares, como se uma era fosse desaparecendo com o surgimento da próxima. Ao contrário, há sempre um processo cumulativo de complexificação: uma nova formação comunicativa e cultural vai se integrando na anterior, provocando nela reajustamentos e refuncionalizações. (SANTAELLA, 2004, p. 13, grifo da autora).

Essa dinâmica exige atenção na contemporaneidade, pois, nesse processo de reorganizar as ciências para se compreender o legado do século passado e apontar caminhos para o que está se desenrolando na atualidade, ciências como história, filosofia, psicanálise, comunicação e semiótica apontam caminhos; porém, não dão conta de mapear o presente, separadamente. Mas, a arte, como sempre, em todos os processos do desenvolvimento da humanidade, pode acompanhar e registrar esse movimento. 
Hoje, ela explica melhor o turbilhão de vivências em que a humanidade está mergulhada e é o espelho do presente, como sempre o foi em todos os momentos do transcorrer e da edificação das culturas. Entender suas linguagens é caminho certo para entender a nós mesmos e não correr o risco de nos perdermos, e não desprezar o mais autêntico deste país: a cultura gerada pelas camadas populares.

\begin{abstract}
Na abertura de seu texto 'A Casa dos Espelhos' (1997) Norman T. White diz que, para ele, 'a arte torna-se viva somente quando ela oferece uma estrutura teórica para questionamentos. A ciência oferece essa estrutura teórica também, mas, para mim', continua White, 'a "boa-ciência" é por demais restritiva. Eu preferiria fazer perguntas que se endereçassem simultaneamente a múltiplos mundos - dos organismos vivos até a cultura, a ferrugem e ao caos. Somente a arte me dá essa generalidade'. (SANTAELLA, 2004, p.26).
\end{abstract}

Para a autora, a arte é o veículo comunicacional que está impregnado do passado, de síntese do presente, mas apontando para o futuro; pois, encontra-se sempre próxima dos "enigmas do real". Afirma, ainda, que, nos tempos mutantes da atualidade, os artistas fornecem as explicações mais imediatas, "pelo simples fato de que, parafraseando Lacan, eles sabem sem saber que sabem". (SANTAELLA, 2004).

As considerações de Santaella também apontam para a pluralidade de conceitos e áreas de conhecimentos necessários para compreender e estudar as manifestações da arte que convivem na sociedade das Eras Culturais.

A dinâmica de coexistência de diferentes culturas é um fenômeno que se tornou visível na formação cultural da Europa, após as idéias que se proliferaram a partir do fim do século XVIII e metade do século XIX, principalmente no e pós-Romantismo, que inovou e apontou para os estudiosos aspectos da cultura muito mais complexos do que supunha a academia, que 
não contemplava as manifestações do povo. O Romantismo não esgotou o assunto; apenas fez com que aflorasse do submundo as artes do povo, condição a que estavam relegadas.

O ideário fundamental dos artistas românticos era indicado pelas palavras gênio, imaginação criadora, originalidade, expressão, comunicação, simbolismo, emoção, sentimento e ideologia. Nenhum desses conceitos estava ausente da arte produzida no passado; mas, a originalidade do fazer plástico dos românticos estava em agrupá-los em suas obras, criando uma nova atitude diante da arte, alterando as suas funções. A manifestação plástica dos românticos revestia-se, portanto, dessa nova ótica, e de um compromisso com o real e o social; nessa perspectiva, as manifestações artísticas do povo ganharam visibilidade.

Um pintor que exemplifica bem essa dinâmica é Goya (1746 1882). Pintor oficial da corte espanhola, que utilizava o artifício da expressão e das imagens carregadas de sutilezas simbólicas para demonstrar a falência da família real e escancarar, em várias obras, a decadência da nobreza da Espanha invadida por Napoleão e, conseqüentemente, do neoclassicismo. Mas, onde mais se encontra o artista romântico, crítico-social do seu tempo e transformador da arte em um veículo comunicacional de denúncia, é no Goya, desenhista e gravador.

A gravura, como forma de arte de reprodução em série, pôde ser explorada como veículo de uma ideologia político-social. Foi um veículo da cultura de massa que se expandia naquele momento histórico. Fizeram parte destas produções de Goya as séries: Desastres da Guerra, os Caprichos, Os 
Provérbios e Tauromaquia; nelas, a condição do humano ganha uma dimensão até então pouco encontrada na arte.

O artista sabia o poder que a representação imagética possui e fez uso desse poder para expor suas angústias e as implicações ideológicopolíticas a que estava sujeito o povo espanhol. Suas gravuras foram produzidas para uso contestatório e como veículo de denúncia, vendidas nos mercados e feiras, perseguidas pela classe dominante. Nelas, estão refletidas outras formas de expressão.

Em seus desenhos e gravuras aparece uma outra Espanha, a Espanha sacrificada pelos poderes, Espanha do povo, que manifestava seus sonhos e desejos e, desta forma, Goya expressa seu repúdio às atrocidades que Ihes eram impostas, através do único veículo possível, mas impossível de ser censurado: a Arte.

Em suas produções, fez uso de diferentes técnicas e estilos pictóricos, usando a imagem como portadora e tradutora dos textos dos intelectuais da época, críticos da realidade desconcertante em que estava submersa a Europa da sua época.

Os governos conduziram-nos, nós os povos, à seguinte situação: no interior, à miséria; no exterior, à guerra. De um lado, o operário desempregado; do outro, o soldado que parte. Daí o problema a resolver, todo o futuro da civilização: ... substituir a obra de morte pela obra de vida. (VITOR HUGO, Correspondências, 1877). ${ }^{113}$

A produção de Goya não se esgota como pintor oficial, gravador ou artista reconhecido pela burguesia; também retrata cenas das festas, das danças, do cotidiano do povo, valorizando o nacional, o regional, os costumes, a natureza, a paisagem de sua terra devastada pela guerra. Esse

\footnotetext{
${ }^{113}$ In Obras Completas de Victor Hugo, Editora das Américas, 1967.
} 
mesmo espírito pode ser encontrado em outros pintores, artistas e pensadores do Romantismo, assim como em outros criadores que, no decorrer do século XX, expressaram, em suas obras, a mesma força criadora e significativa oriunda das artes românticas e populares.

O artista Ranchinho e muitos outros do Museu de Assis guardam semelhanças com as obras dos românticos, quando exprimem em suas pinturas a mesma energia capaz de retratar a vida, o momento histórico, o conflito social, a emoção que impactam a consciência. Seus trabalhos possuem propostas estéticas e técnicas diferenciadas do artista espanhol, mas captam o instante efêmero da presença dos conflitos do homem e os transforma em registro atemporal.

Nesta perspectiva, o pensamento romântico atravessa o tempo e contribui para ampliar as conceituações de cultura e consciência brasileiras, assim como as obras do Museu de Assis e os documentos do CEDAP se transformam em matéria-prima para tipificar as produções das culturas subalternas que sobrevivem e que também estão presentes na Era das Culturas, descrita por Lucia Santaella.

O historiador Elias Thomé Saliba (2003), nas considerações finais de seu livro As utopias românticas reflete e pergunta sobre as contribuições dos pensadores românticos como forma metodológica que pode ser utilizada na ampliação e esclarecimento de nossa realidade, e aponta, ainda, caminhos para compreender o momento presente. Nessas considerações, ele vai além das restrições apontadas por García Canclini quanto ao romantismo em seu livro As Culturas Populares no Capitalismo. 
crescem numa sociedade e num tempo para os quais se constituem em respostas. As utopias românticas, gestadas na aurora da sociedade industrial e alimentando-se no torvelinho das revoluções burguesas, sugiram como resposta aos desafios do seu tempo. [...] as utopias modernas e, em especial, as modalidades românticas aqui analisadas, esforçaram-se por imaginar um mundo ideal mais acessível ou, pelo menos, mais próximo aos homens reais. [...] Mas esta concepção de tempo e de história das utopias românticas naquilo que elas almejam, às vezes, com febril impaciência messiânica, a transformação total da sociedade - tem muito a ver, ainda que por vias sinuosas, com alguns dos dilemas de nosso tempo. É possível pensar as alternativas contemporâneas de transformação, sem pensá-las por inteiro e sem o apoio da dimensão global, isto é, sem aquele esquema de revolução? Talvez partindo desta inquietação maior, possamos interrogar as utopias românticas, pois elas foram, em toda a sua variedade e mutiplicidade de caminhos, profundamente sensibilizadas por uma imperiosa e urgente necessidade de transformações globais da sociedade. [...] Parece que, hoje, o tempo e a historia perderam todo o seu romantismo utópico, foram como que 'desdramatizados' e conspiram, no fim das contas, contra a identidade cultural dos homens e das sociedades. ... Em períodos de transição social, quando tudo mergulha no torvelinho das mudanças rápidas, como pensar a existência humana como um todo? (SALIBA, 2003, p.103-104).

A condição do humano está sempre impregnada de

borbulhante ânsia de conhecer o passado, entender o presente e manter uma

crença no futuro. O incognoscível sempre impulsiona o homem a questionar e

pensar, com a finalidade de traduzir as observações empíricas da vida em

conceitos que possam ser usados para a melhoria da coletividade; o que

requer, sempre, transformar o viver em textos, em imagens, em arte, ou seja,

em linguagens verbais e não-verbais.

De certo modo, acho que sempre escrevemos sobre algo que não conhecemos, escrevemos para dar ao mundo não-escrito uma oportunidade de expressar-se através de nós. Mas, no momento em que minha atenção vagueia da ordem estabelecida das linhas escritas para a complexidade mutável que nenhuma frase consegue apreender totalmente, chego quase a entender que além das palavras há algo que as palavras poderiam significar. (CALVINO, 2005, p. 147).

As artes produzidas pelas culturas populares retratam tradições

que se articulam com a estrutura psicossocial das populações, como na 
escolha das cores, dos temas, na forma de retratar o cotidiano e, principalmente, porque não estão preocupadas em teorizar e questionar o viver e sim em retratá-lo como ele é, bem como é retratada nesse mesmo viver a sensibilidade de cada um - é o olhar de quem está dentro do processo e não daquele que se utiliza dele para criar uma nova leitura das realidades. Essa atitude de olhar de fora é própria da arte erudita.

Nas artes populares são retratados os costumes, os rituais, as lendas e mitos, a paisagem como eles são. Este "ser brasileirista" é que as transforma em importantes fontes de leituras das realidades, verdadeira representação do pensar. As artes populares fazem por elas mesmas o que o modernista Mário de Andrade se propôs a fazer pelo modernismo: "Estou inteiramente pau-brasil e faço uma propaganda danada do pau-brasilismo. Em Minas, no Norte, Pernambuco, Paraíba, tenho amigos que estou paubrasileirando". (AMARAL, 1975, p. 369-370).

A produção dos artistas populares reflete as interferências ideológicas e as dinâmicas de modernização ocorridas em seu meio. Essas imagens ou representações imagéticas encontradas em suas culturas explicitam as ressignificações propostas a partir das mensagens recebidas e adaptadas no cotidiano.

Portanto, as representações imagéticas geradas nas culturas subalternas são carregadas de sentidos e possibilitam compreender a identidade cultural que estrutura as significações das comunidades em suas relações sociais. Segundo García Canclini (1983), "toda produção cultural surge, $[. .$.$] a partir das condições materiais de vida e nelas está arraigada". Da$ mesma forma, recriam através de seus próprios códigos essa realidade, de 
forma única, fazendo uso de uma linguagem estética própria, usando quando Ihe convêm, os cânones da arte erudita. Ainda, segundo García Canclini (1983),

\begin{abstract}
ambos os espaços, o da cultura hegemônica e o da cultura popular, são interpenetrados, de modo que a linguagem particular dos operários ou dos camponeses é em parte uma construção própria e em parte uma ressemantização da linguagem dos veículos de comunicação de massa e do poder político, ou um modo específico de alusão às condições sociais comum a todos.
\end{abstract}

As manifestações plásticas das classes subalternas são, deste modo, fiéis ao universo em que estão inseridas e depositárias do ethos que registram, como são também veículos comunicacionais dos modos viventes de quem as produz, das suas formas de pensar e agir e, portanto, importantes documentos para analisar a evolução das festas populares estudadas, objeto primeiro de análise deste estudo.

Algumas obras apresentadas neste capítulo pertencem ao Museu de Assis; outras foram escolhidas em diferentes fontes - inclusive em blogs mantidos por artistas na internet - para exemplificar que as artes produzidas pelos artistas populares não deixam dúvida quanto à caracterização das relações sociais nelas existentes, bem como de todos os elementos iconográficos que estão presentes nas festas estudadas.

Nesse sentido, passam a ser uma narrativa minuciosa da realidade e não permitem dúvidas quanto ao que descrevem e do que falam; são precisas quanto às representações da espacialidade ${ }^{114}$ do campo e do urbano; fornecem uma apreciação crítica do social que muitas vezes é difícil aos pertencentes das camadas subalternas expressar verbalmente e, o mais

\footnotetext{
${ }^{114}$ O termo espacialidade é usado no sentido compreendido por Milton Santos, que entende o espaço como uma ressignificação do existir do homem neste espaço dialeticamente pelas forças de produção material e, portanto, criando culturas próprias em cada espaço e tempo. "O ato de produzir é igualmente o ato de produzir espaço". (SANTOS, 1974, p.174).
} 
contundente, é a realidade que aflora, só vista e sentida por quem dela

participa.
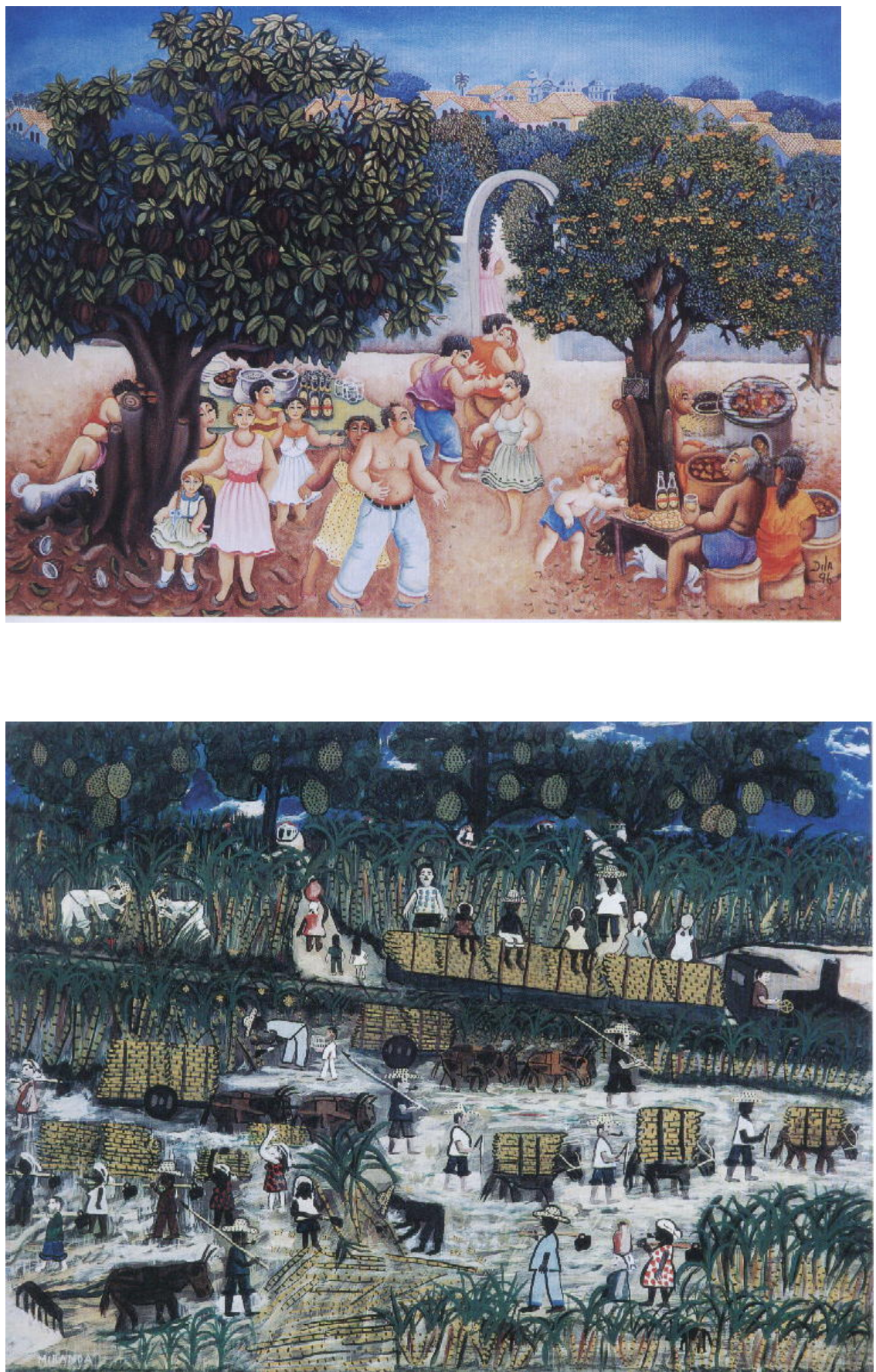

Imagem 5.1:

Dila

Festa no quintal

óleo s/tela.

$60 \times 80 \mathrm{~cm} .1996 . .^{115}$
Imagem 5.2:

Miranda

Plantação de canade-açúcar

óleo s/eucatex

$70 \times 100 \mathrm{~cm}$.

s/data ${ }^{116}$

\footnotetext{
115 In ARDIES, Jacques; textos de Geraldo Edson de Andrade. A arte naif no Brasil. São Paulo: Empresa das Artes, 1998, pág. 127- "Festa no quintal" explicita vários aspectos do cotidiano da contemporaneidade: festa de bairro de caráter popular, radinho, rótulo da marca da cerveja, churrasqueira de tubo de concreto, refrigerante em lata; mas explicita também os laços de afetividade e identifica que a festa se passa provavelmente na região nordeste pela presença do pé de cacau.

${ }^{116}$ ARDIES, Jacques; textos de Geraldo Edson de Andrade. A arte naif no Brasil. São Paulo: Empresa das Artes, 1998. pág. 61. Em "Plantação de cana de açúcar" é possível identificar as tramas das relações sociais que envolvem esse trabalho no país, como: o transporte de bóias-frias, o trabalho infantil, a hierarquia no trabalho do corte de cana e a falta de equipamento para segurança do trabalho.
} 


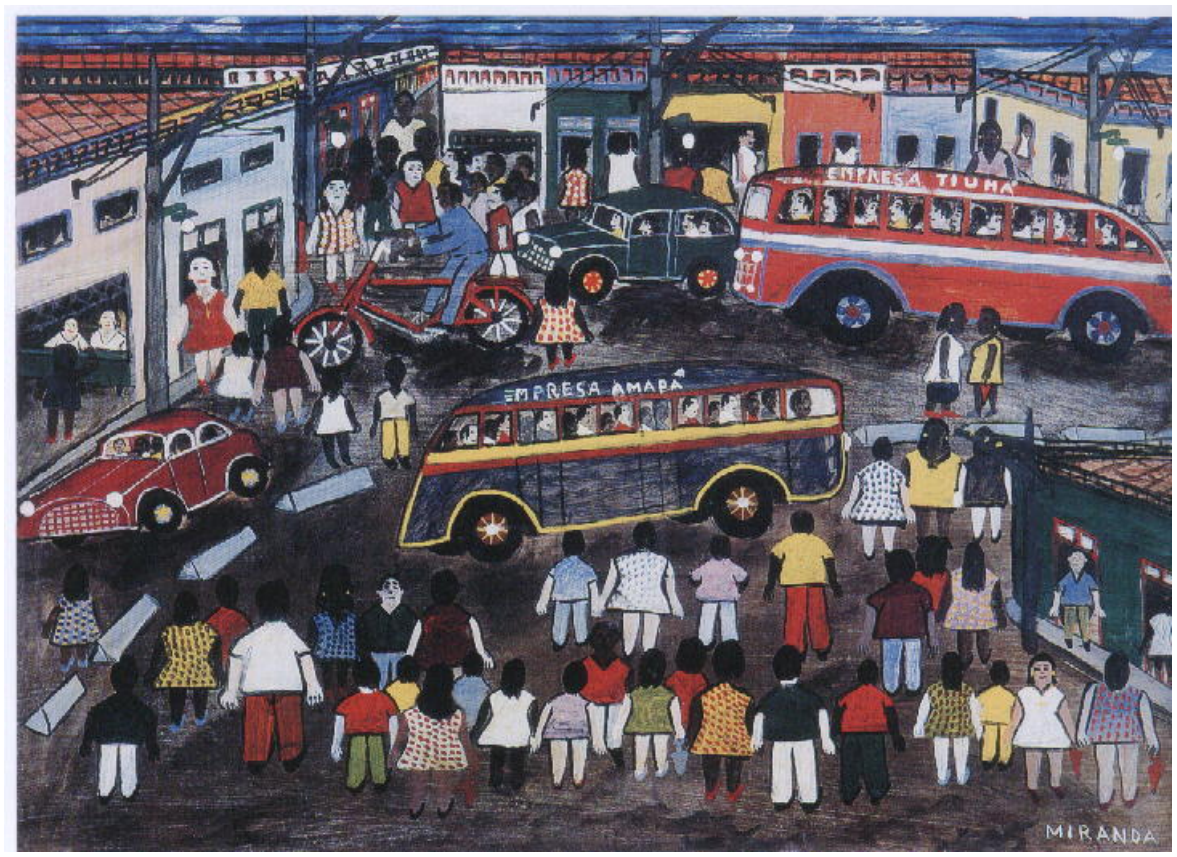

Imagem 5.3:

Miranda

O tráfego

óleo s/eucatex

$70 \times 100 \mathrm{~cm}$.

$1974^{117}$

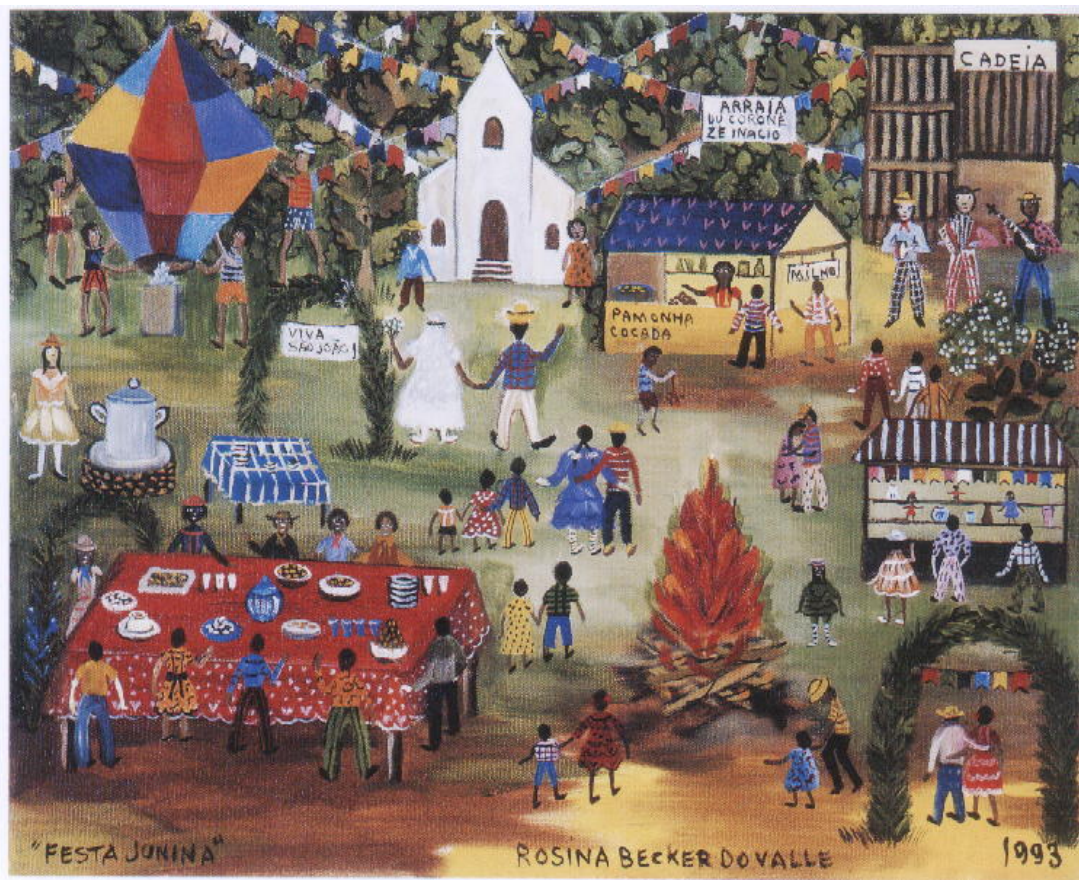

Imagem 5.4:

Rosina Becher do

Valle

Festa Junina

óleo s/tela

$40 \times 50 \mathrm{~cm} .1993^{118}$

117 ARDIES, Jacques; textos de Geraldo Edson de Andrade. A arte naif no Brasil. São Paulo: Empresa das Artes, 1998. pág. 60. Em "O tráfego", a espacialidade do urbano é totalmente explicitada, principalmente a falta de planejamento urbano, o comércio e caracterização de uma arquitetura própria do interior do país.

118 In ARDIES, Jacques; textos de Geraldo Edson de Andrade. A arte naif no Brasil. São Paulo: Empresa das Artes, 1998, pág. 108. Neste quadro, é encontrada a maioria dos elementos presentes nas inúmeras festas juninas do país, desde diversões, indumentárias, comidas, a atividades profanas e sacras. 


\title{
5.3 Imagens que Contam das Festas
}

\begin{abstract}
Ler significa reler e compreender, interpretar. Cada um lê com os olhos que tem. E interpreta a partir de onde os pés pisam. Todo ponto de vista é a vista de um ponto. Para entender como alguém lê, e necessário saber como são seus olhos e qual é sua visão de mundo. Isso faz da leitura sempre uma releitura. A cabeça pensa a partir de onde os pés pisam. Para compreender, é essencial conhecer o lugar social de quem olha. [...] Sendo assim, fica evidente que cada leitor é co-autor. Porque cada um lê e relê com os olhos que tem. Porque compreende e interpreta a partir do mundo que habita. (BOFF, 1997, p. 9-10).
\end{abstract}

Neste tópico, as pinturas do Museu de Arte Primitiva de Assis serão utilizadas para ilustrar considerações que dêem sustentação a uma parte dos argumentos deste trabalho, no que se refere à importância das manifestações imagéticas na construção dos registros que explicitam o ethos das culturas populares. Esses documentos visuais são contundentes e não permitem interferências quanto às realidades explicitadas e sua interpretação, como se pôde notar, anteriormente, na imagem 5.2.

A citação de Boff (1997) remete para o exercício de se refletir sobre a condição das mensagens visuais, sobre as tradições passadas pela oralidade, sobre os textos escritos e imagéticos. É pela palavra que se materializa o pensamento; do mesmo modo, é através da escrita - e neste trabalho as representações iconográficas são vistas como registros - que o pensamento é preservado; mas, "ler significa reler e compreender, interpretar. Cada um lê com os olhos que tem. E interpreta a partir de onde os pés pisam". As linguagens não-verbais são, desse modo, um instrumento eficaz para ler e interpretar os tempos, os costumes, os sentimentos. A imagem, principalmente a figurativa, é incontestável. A imagem 5.8 é um bom exemplo. 
"[...] a existência se passa em um rolo de imagens que se desdobra continuamente, imagens capturadas pela visão e realçadas ou modeladas pelos outros sentidos, [...] configurando uma linguagem feita de imagens traduzidas em palavras e de palavras traduzidas em imagens, por meio das quais tentamos abarcar e compreender nossa própria existência. [...] qualquer que seja o caso, as imagens, assim como as palavras, são a matéria de que somos feitos. [...]

As imagens, porém, se apresentam à nossa consciência instantaneamente, encerradas pela sua moldura - a parede de uma caverna ou de um museu - em uma superfície específica. [...] Com o correr do tempo, podemos ver mais ou menos coisas em uma imagem, sondar mais fundo e descobrir mais detalhes, associar e combinar outras imagens, emprestar-Ihe palavras para contar o que vemos mas, em si mesma, uma imagem existe no espaço que ocupa, independente do tempo que reservamos para contemplá-la." (MANGUEL, 2001, p. 21-25, grifos da autora).

Os acervos de Assis - Museu e CEDAP - podem ser incluídos como representantes da cultura dominante (hegemônica), mas também se transformam em um legado fundamental para a compreensão das culturas populares subalternas e do ethos nacional. Desse modo, compreender o acervo de Assis é compreender, pela imagem, a formação cultural da própria região e do país. Ver imagens: 5.2; 5.3; 5.4; 5.5; 5.11 e 5.13.

As comunidades da região se formaram e se estruturaram a partir das primeiras décadas do séc. XX. São portadoras, desde sua origem, de elementos próprios da cultura de massa que emergia no mesmo período. Isso contribuiu para desenvolverem atitudes de não preservação da memória, de aceitação imediata do novo, de inserção na sociedade de consumo e de desconstrução do existente em favor do moderno.

Como mencionado no capítulo quatro, no espaço de aproximadamente setenta anos, os núcleos urbanos da região e a dinâmica rural existente foram totalmente alterados e muito do patrimônio histórico cultural já se perdeu ou se alterou. As manifestações culturais representadas nas obras do Museu de Assis que caracterizam o cotidiano são, portanto, neste trabalho, fontes de pesquisa para a compreensão da cultura popular da 
atualidade e preservação da memória. A imagem 5.1 ilustra esse representar a atualidade, na ótica das culturas subalternas.

As tradições das comunidades populares, em sua maioria, são preservadas pela oralidade, bem como pelas representações imagéticas. A oralidade é constituída pelo domínio e decodificação da língua local, do mesmo modo que os processos da escrita são constituídos por códigos que devem ser conhecidos e decodificados dentro do grupo, para materializar e registrar a oralidade.

Como apontado anteriormente, entende-se a imagem como uma linguagem que possui seus próprios códigos. Desta forma, as imagens produzidas pelas culturas populares só são decodificadas se seus leitores dominam esses códigos. Sendo assim, as representações imagéticas das culturas populares e as representações imagéticas das festas, objeto maior deste estudo, são encaradas como textos que, para serem decodificados, necessitam da oralidade e dos conhecimentos oriundos dos grupos nos quais estas imagens estão inseridas, como nas imagens 5.5; 5.6; 5.9; 5.11; 5.12 e 5.14 .

É sob esta ótica que os textos imagéticos do Museu de Assis são vistos e valorizados, neste trabalho, como registros das culturas e das festas populares; indo além, são registros das tradições mantidas pela oralidade e perpetuadas pelas expressões imagéticas. $E$, como já mencionado, são também formas de expressão artística. 


\subsection{O Artista-Tradutor do Viver em Imagens}

O artista popular retrata as realidades acumuladas no transcorrer do processo histórico-dialético. Ao elaborar suas obras, utiliza-se de elementos mantidos pelas tradições que, por sua vez, também são ressignificados. Deste modo, ao se ler uma obra de arte de artistas populares, lê-se o registro da própria manifestação cultural das comunidades populares subalternas. Ela retrata a espacialidade das comunidades e as interferências nelas ocorridas (imagens 5.2; 5.3 e 5.4) - mesmo quando a opção do artista recai sobre trabalhos não figurativos. O artista plástico popular torna-se, então, um documentarista dos poderes e controles que as culturas hegemônicas impõem a ele e seu meio. O artista é um criador de uma realidade que, ao ser recortada, transcende o espaço e o tempo em que foi gerada.

$\mathrm{O}$ ato de criar e registrar visualmente explicita um campo de conhecimento próprio que o artista faz aflorar a partir da sua própria vivência e experiência. Nas artes populares, essa vivência se dá de dentro para fora. Para elaborar sua obra, o artista popular explicita o tempo, o espaço e a vivência de sua realidade. Neste sentido, tempo, espaço e as tradições mantidas pela oralidade, das quais ele é depositário, passam a ser manipulados pela carga cultural, religiosa e mística de cada artista. Os documentos pesquisados no CEDAP e transcritos acima exemplificam essa vivência.

Nas artes populares é possível encontrar artistas que recorrem a diferentes técnicas e suportes; fazem uso, indiscriminadamente, dos 
conhecimentos que lhe são apresentados no decorrer de seu percurso de criação, bem como fazem uso, quando lhes interessa, de diferentes meios para divulgar seu trabalho, não se importando com as categorizações impostas pelo mercado ou pelas teorizações produzidas pelos meios hegemônicos do fazer estético.

E, nesse sentido, o conceito de estética ainda está, dentro da História da Filosofia Ocidental, ligado ao conceito de Ética, e a Ética retoma o conceito de Moral que, por sua vez, categoriza o viver do homem em bem, belo, divino, que se opõe à mal, feio, satânico, agnóstico - categorizações maniqueístas herdadas da Filosofia Antiga e Renascentista - e que ainda prevalecem, principalmente, onde a tradição judaico-cristã se faz presente.

Para os artistas populares, este sentido ético-estético está ligado a sua realidade histórico-cultural e as suas relações sociais. A dimensão ético-estética dos artistas das camadas populares caracteriza sua coletividade como eles a concebem, incorporando formas do cotidiano, do sagrado, do profano, do trabalho e do lúdico. "Cada um lê com os olhos que tem. E interpreta a partir de onde os pés pisam." (BOFF, 1997). O sentido estético das culturas populares é construído a partir das similaridades que o artista representa e das vivências em sua própria comunidade. Esse fazer éticoestético apresenta também uma forma de organizar as dinâmicas culturais e comunicacionais de sua contemporaneidade. Ver imagem 5.3.

Assim, as representações imagéticas escolhidas entre os artistas do Museu de Assis (imagens 5.5 a 5.15) podem dialogar com as considerações deste capítulo e com os levantamentos e as documentações visuais (fotos e filmagens) realizadas nas festas de Folias de Reis pesquisadas. 
As imagens deixam transparecer os principais elementos iconográficos constitutivos das folias e são registros fidedignos para ancorar as propostas deste trabalho, quanto à relevância das representações visuais como veículos comunicacionais e depositários das tradições culturais e das tradições passadas pela oralidade nas culturas populares subalternas. Como se pode observar na imagem 5.8, onde o presépio é representado e adorado por uma criança. Nesta obra, os elementos registrados pelo artista estão muito próximos dos presépios documentados durante a pesquisa realizada: as flores, as fitas, o colorido típico dos presépios de Folias de Reis, a presença de outros Santos de devoção, bem como a evocação de uma cena rural, indicada pela presença de um ratinho que corre embaixo da mesa onde está armado o presépio. Nas imagens 5.6 e 5.14, os Reis e a jornada feita por eles para encontrar o Menino, como descritos pelos foliões, estão detalhadamente representados. Podem-se notar a caracterização etnográfica atribuída a cada rei - o africano, o oriental e o europeu - a estrela os conduzindo para Belém, e os presentes que seriam ofertados.

Nas imagens $5.5 ; 5.9 ; 5.11 ; 5.12 ; 5.15$ e 5.17 , é possível identificar alguns elementos iconográficos, sem os quais as folias não poderiam ser reconhecidas e constituídas, tais como: a bandeira, o mastro, as fantasias dos palhaços, suas máscaras e bastões, as fantasias dos Reis, a disposição dos músicos, como descritos no capítulo três deste trabalho, e as imagens 5.7; 5.8; 5.10 e 5.13 representam os presépios (ou lapinhas), contendo os elementos da natividade descritos nos textos do Novo Testamento que, pela tradição, desde São Francisco de Assis, os compõem. Assim, pode-se entender o artista e suas obras pela ótica de Joly: 
[...] a imagem assemelha-se ou confunde-se com o que representa. Visualmente imitadora, pode enganar ou educar. Reflexo, pode levar ao conhecimento. A Sobrevivência, o Sagrado, a Morte, o Saber, a Verdade, a Arte, se tivermos um mínimo de memória, são os campos a que o simples termo 'imagem' nos vincula. Consciente ou não, essa história nos constituiu e nos convida a abordar a imagem de uma maneira complexa, a atribuir-lhe espontaneamente poderes mágicos, vinculada a todos os nossos grandes mitos." (JOLY, 1999, p.19).

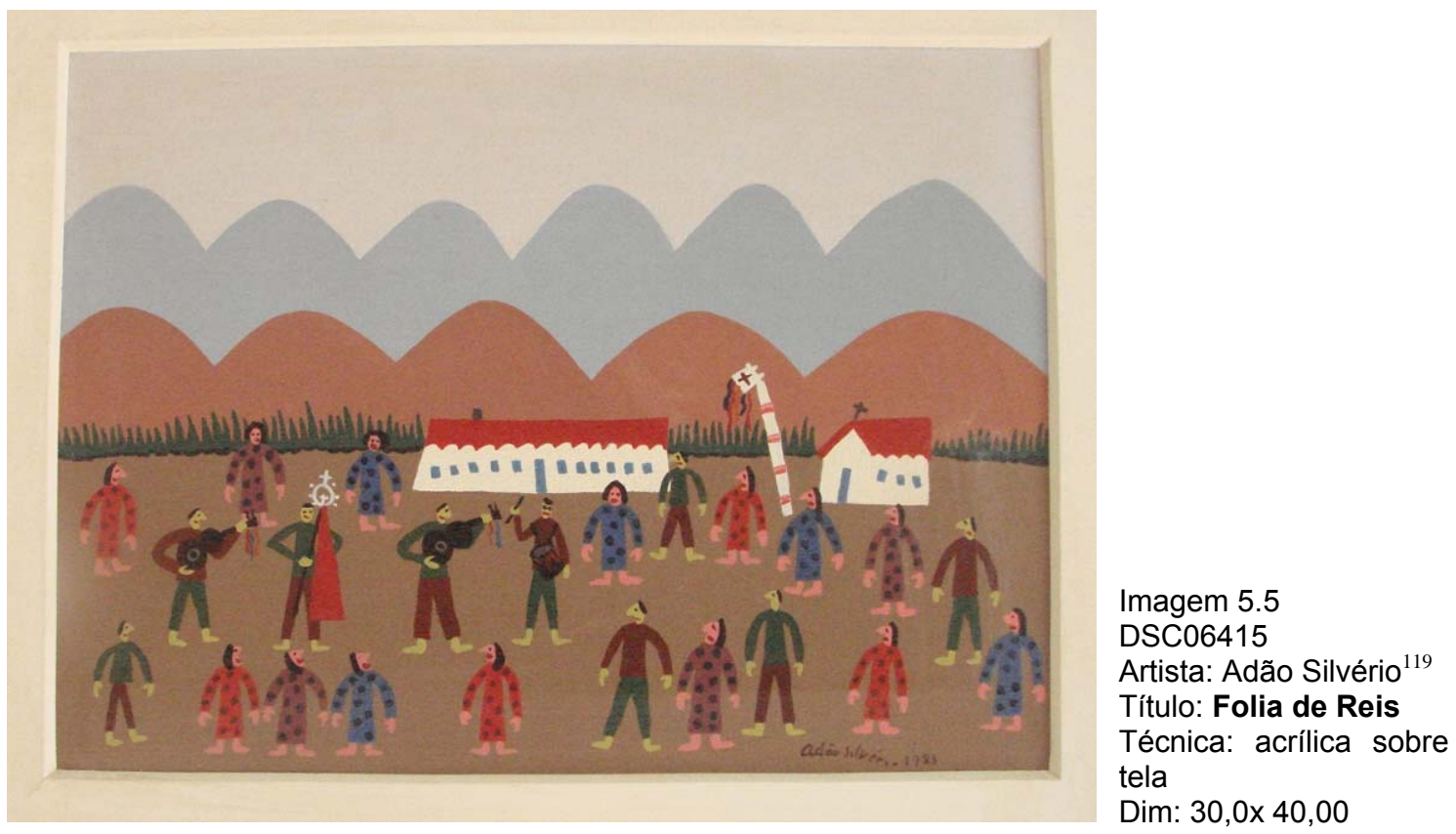

${ }^{119}$ Adão Silvério - Adão José Santos nasceu em 5 de novembro de 1942 em Redenção da Serra - SP. Iniciou-se na pintura em 1965, tendo, desde sua infância, interesse pelo desenho. Pintor autodidata, retrata, com seu estilo, o homem interiorano, festas e danças folclóricas, monjolos, rodas d'água, engenhos, etc. 


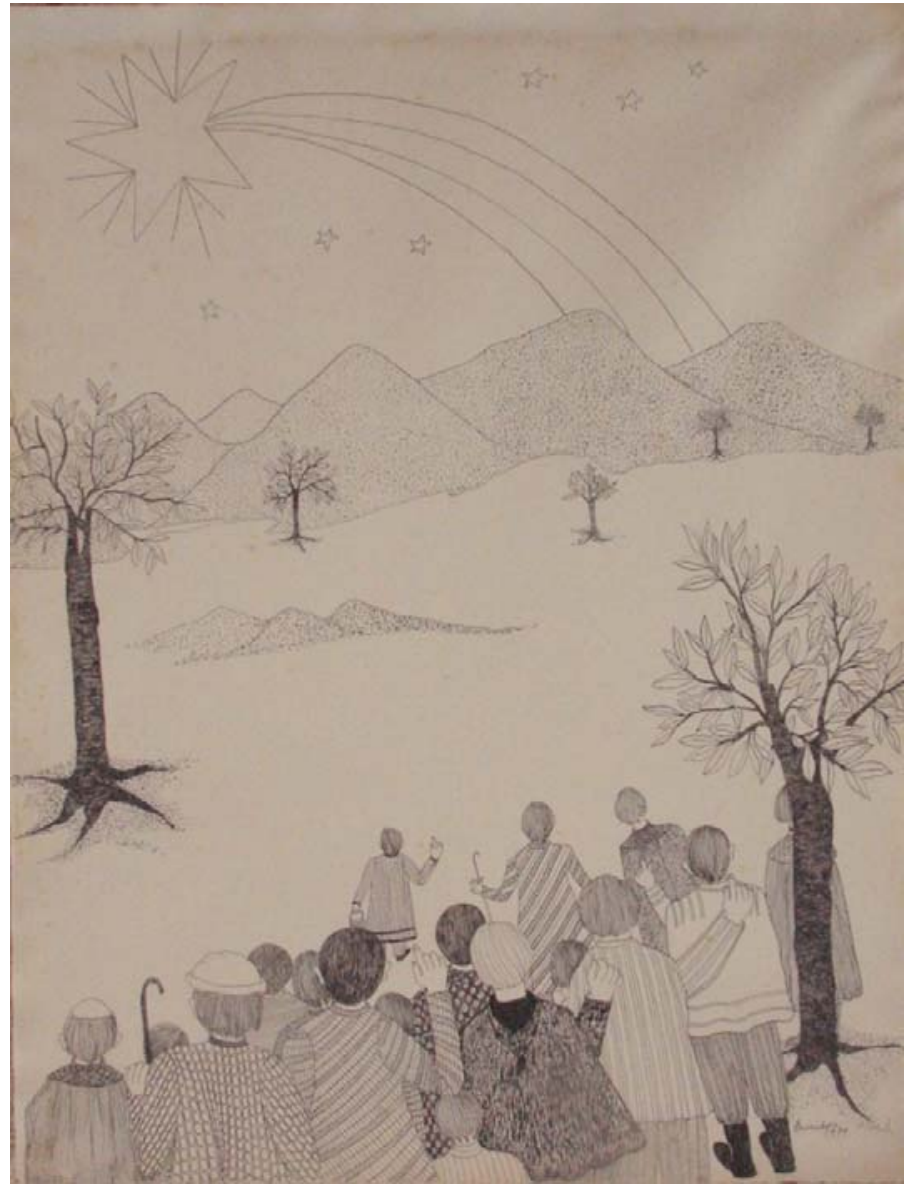

Imagem 5.6

DSC06412

Artista: Euridyce ${ }^{120}$

Título: Povo a caminho de Jerusalém

Técnica: Bico de pena

Dim: $51,5 \times 40,0$

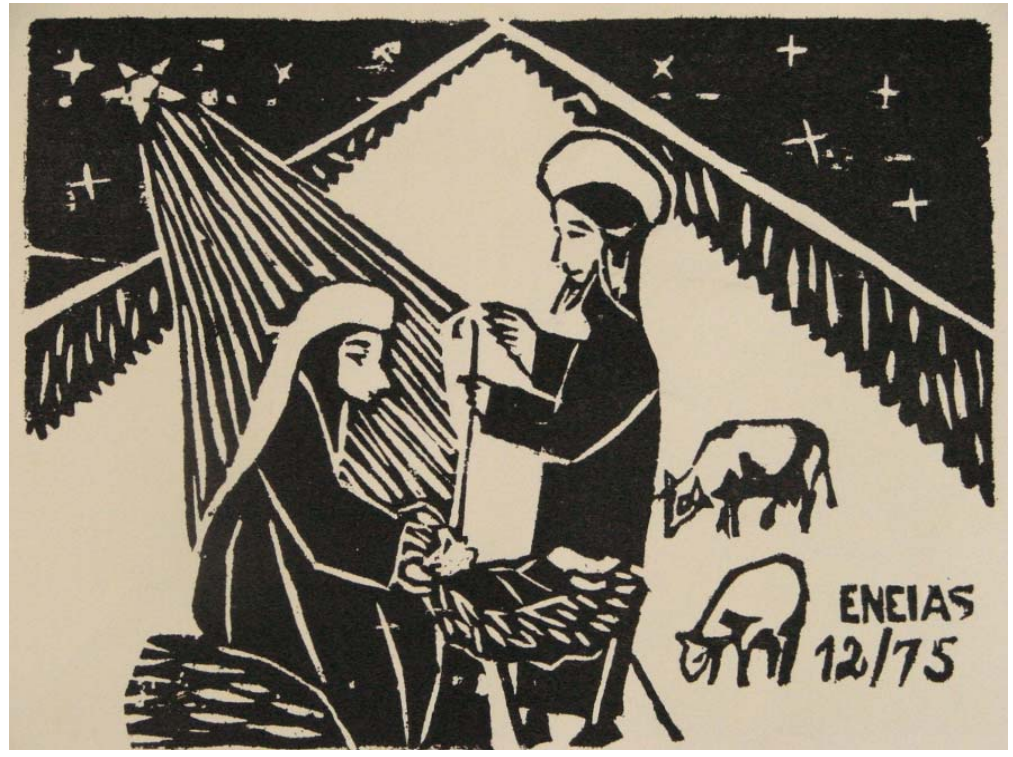

Imagem 5.7

DSC06409

Artista:

Santos ${ }^{12}$

Título: Presépio

Técnica: Xilogravura popular

Dim: 20,0x15,00

${ }^{120}$ Euridyce Bressane (RJ, 1906-1989) - desenha reminiscências e aspectos gravados em sua memória.

121 Enéias Tavares dos Santos nasceu em 22 de novembro de 1931, em Marechal Deodoro, AL. Filho de agricultores, teve instrução primária incompleta e, já adulto, estudou música, desenho e pintura, não chegando a completar os estudos por razões econômicas. Aprendeu xilogravura sozinho, tendo realizado, entre inúmeros outros trabalhos, uma Via-Sacra para a Galeria de Arte de Aracaju - SE. 


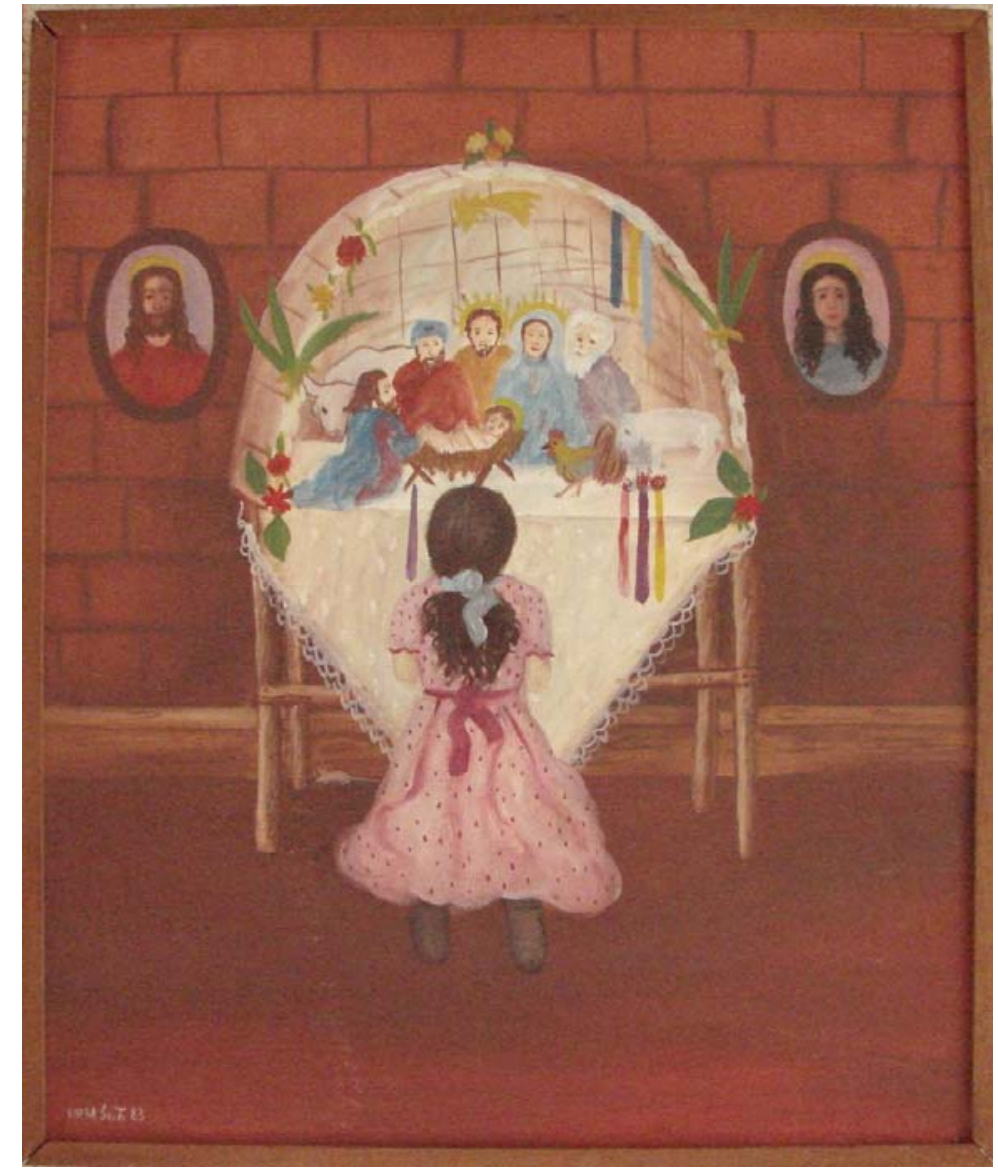

Imagem 5.8

DSC06406

Artista: Omar Souto ${ }^{122}$

Título: Presépio

Técnica: óleo sobre tela

Dim: 50,0x60,5



Imagem 5.9

DSC06400

Artista: Semearte

Técnica: mista

122 Omar Souto nasceu em 1946, em Itaberaí, Goiás. Filho de nordestinos, começou como pintor de paredes, letreiros e placas. Ao iniciar seu trabalho, ordenou as idéias na apreensão religiosa do homem simples que busca consolo nas romarias. Posteriormente, suas obras mostram o homem sertanejo, seu chão, sua casa, crenças e evasão. Ao abordar o homem do campo diante das dificuldades para enfrentar a vida, e o abandono dos roçados na procura das cidades, o artista emite uma visão social de grande validade sobre o Centro-Oeste agrário e pecuário. 


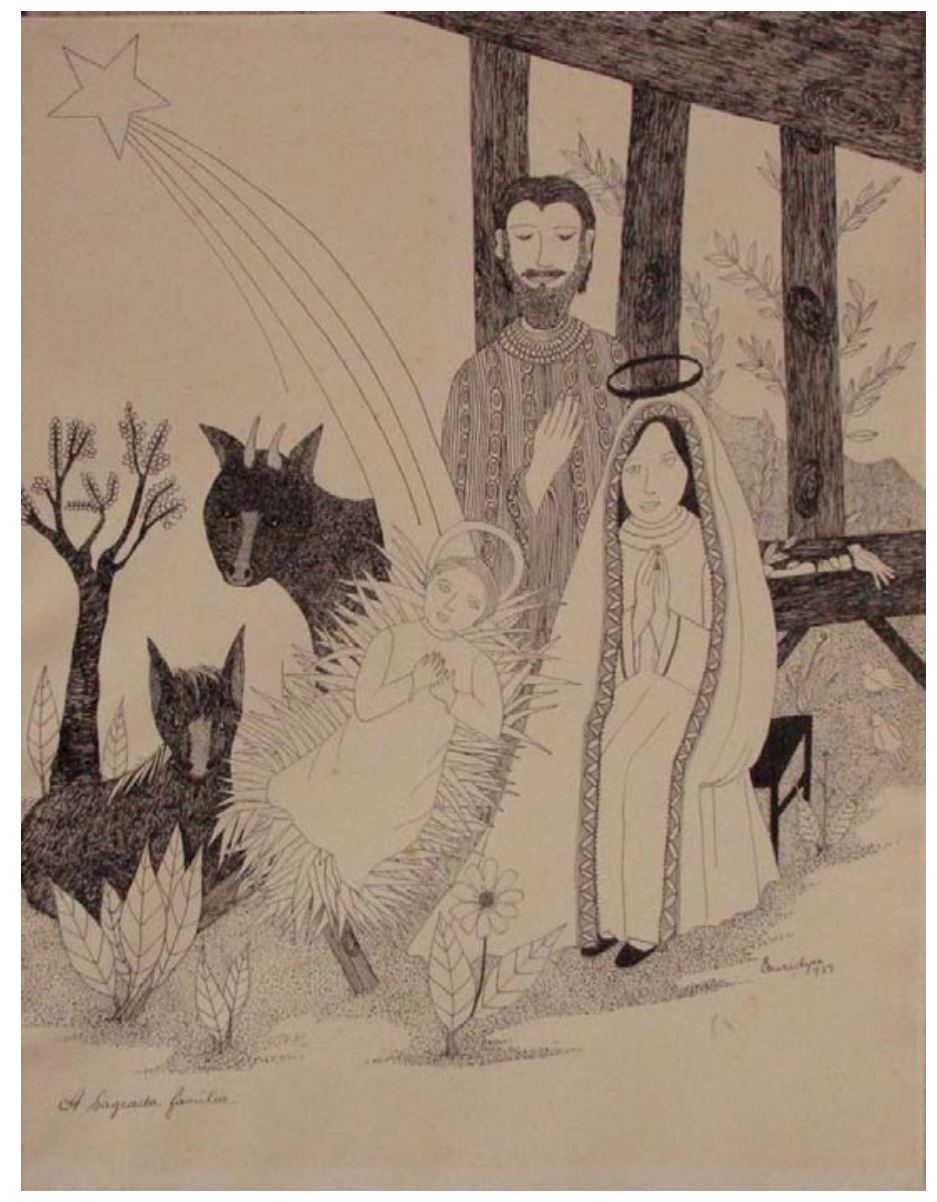

Imagem 5.10

DSC06393

Artista: Euridyce

Título: A sagrada família

Técnica: Bico de pena

Dim: 40,0x51,5

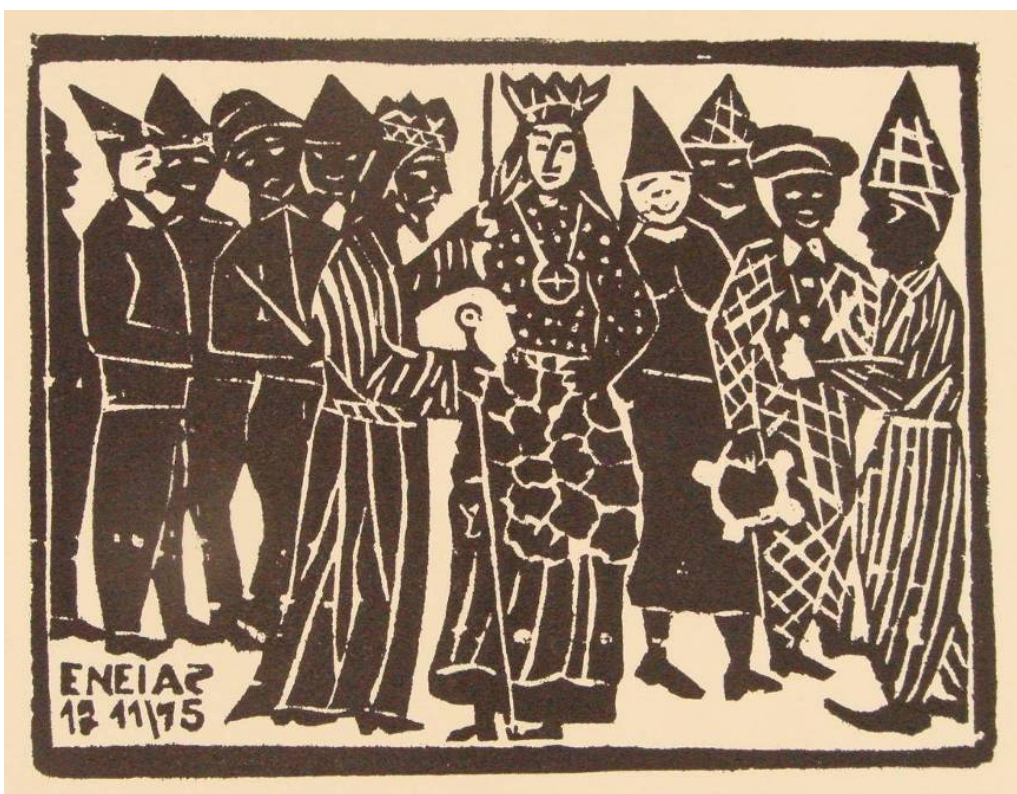

Imagem 5.11

DSC06389

Artista: Enéias Tavares Santos

Título: Reisado

Técnica: Xilogravura popular Dim: 20,0x15,0 


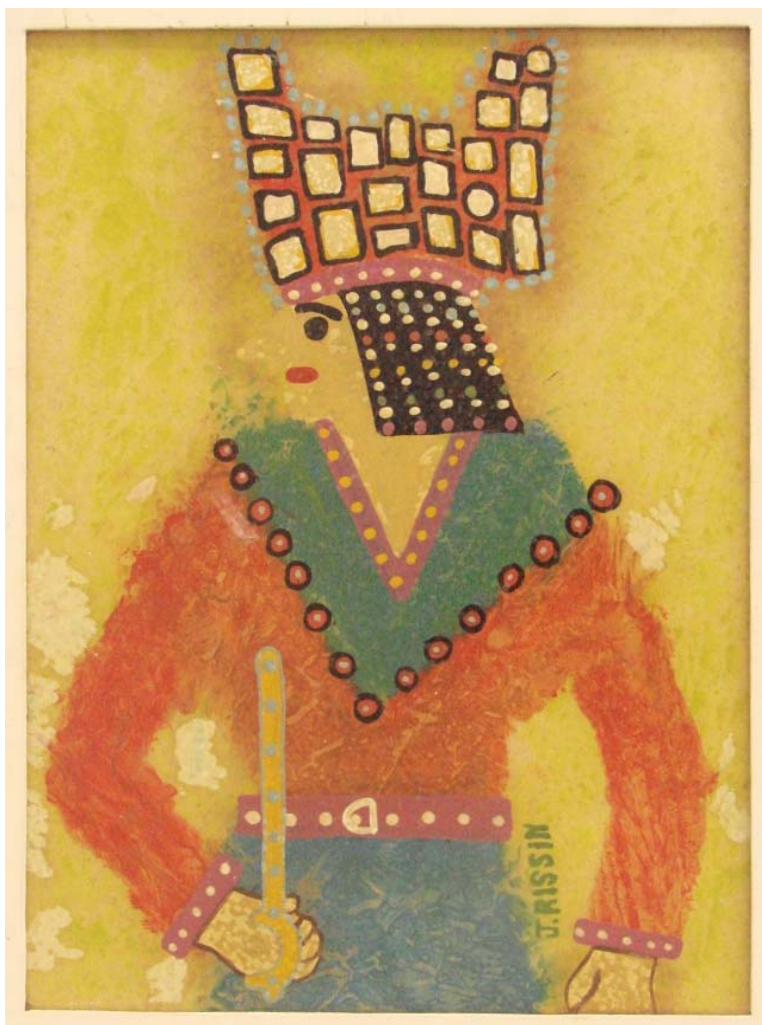

Imagem 5.12

DSC06391

Artista: J.Rissin ${ }^{123}$

Título: Figura de Reisado

Técnica: monotipia

Dim: $28,0 \times 38,0$



Imagem 5.13

DSC06386

Artista: Euridyce

Título: 0 menino Jesus

Técnica: Bico de pena

Dim: 40,0×51,5

${ }^{123}$ Jacob Kopel Rissin nasceu em Recife em 1929. 


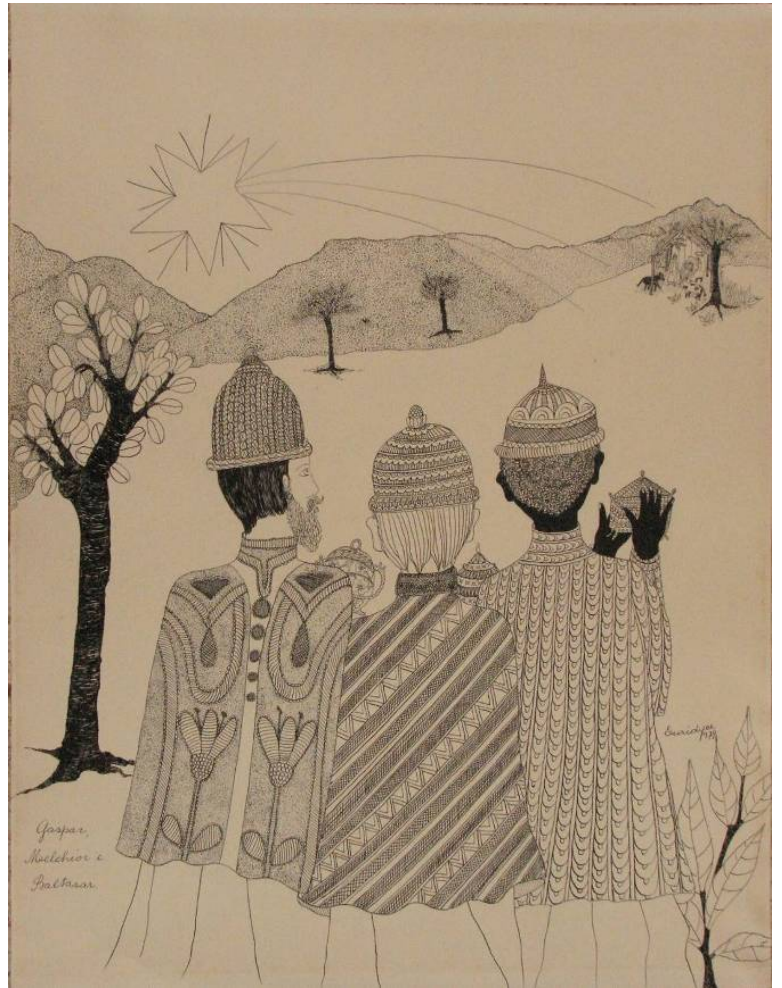

Imagem 5.14

DSC06384

Artista: Euridyce

Título: Gaspar, Melchior e

\section{Baltazar}

Técnica: Bico de pena

Dim: $51,5 \times 40,0$

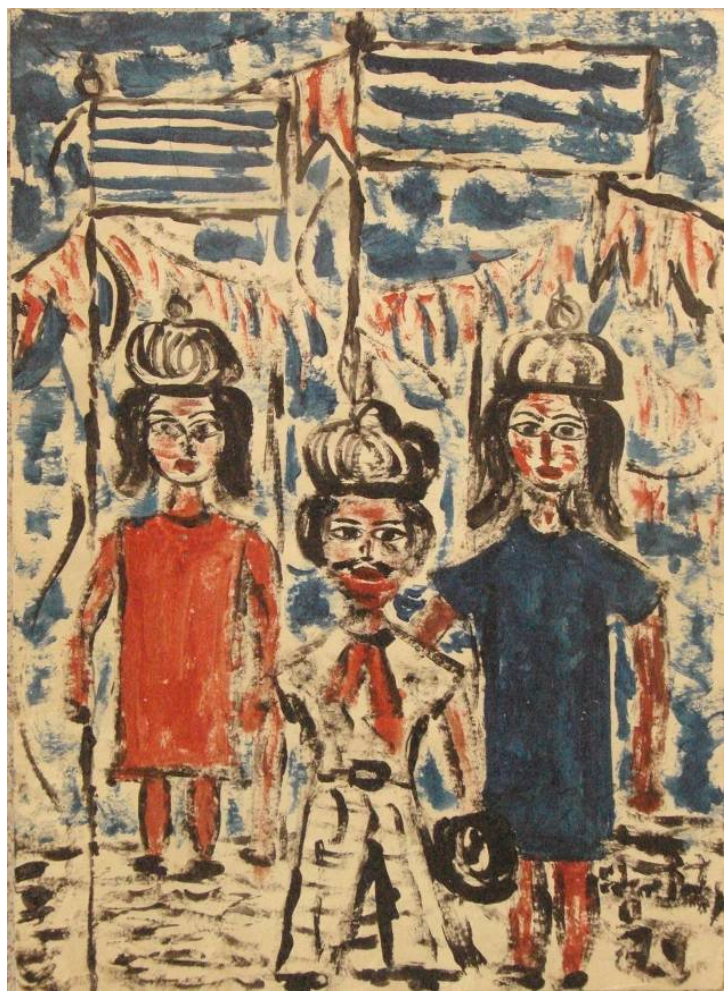

Imagem 5.15

DSC06382

Artista: Edgar Bastos ${ }^{124}$

Título: Reisado

Técnica: óleo sobre papel canson Dim: 23,0x32,0

${ }^{124}$ Edgar Bastos - Pintor alagoano, falecido em 2002. 


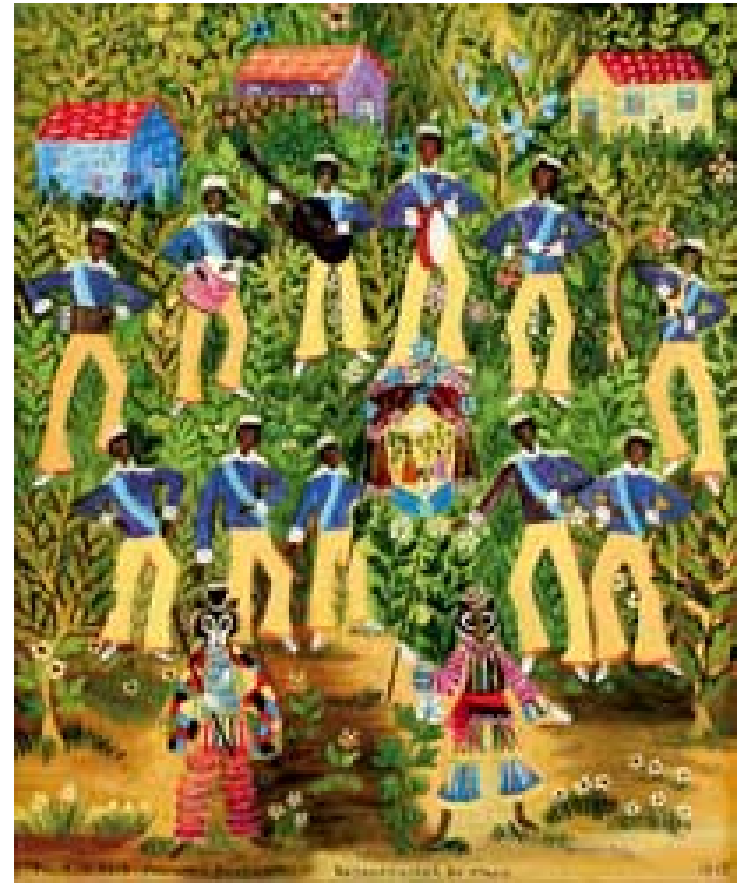

Imagem $5.16^{125}$ :

Título: Folia de Reis Folclore Brasileiro

Autora: Rosina Becker

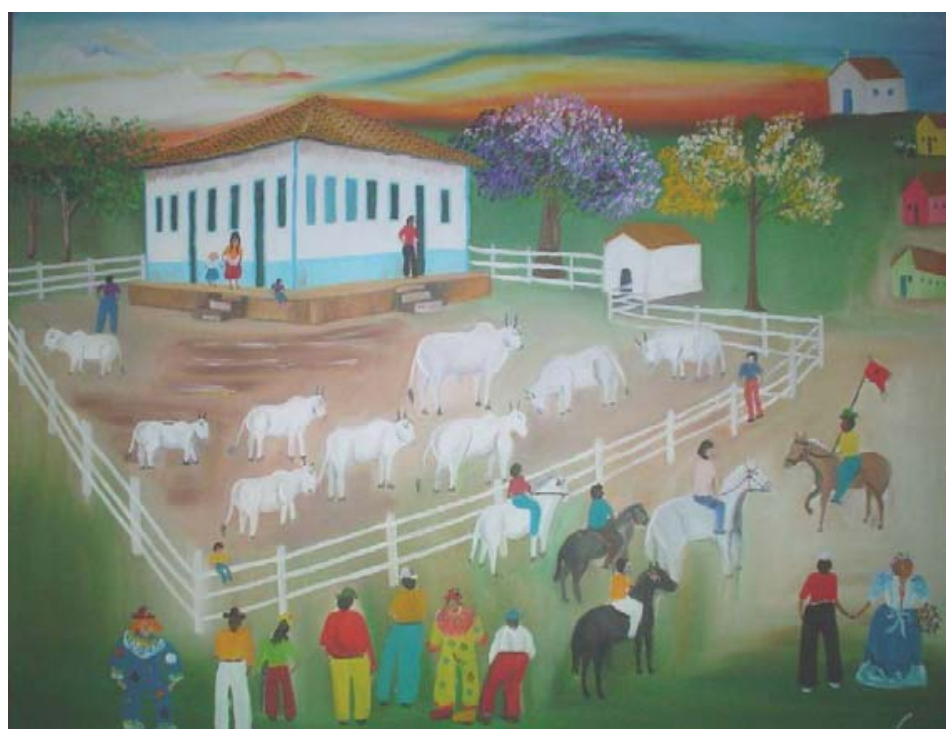

Imagem $4.17^{126 .}$

Folia de Reis

Autor: Dag França

${ }^{125}$ Folia de Reis Folclore Brasileiro (imagem de internet). Óleo sobre tela, $62 \times 50 \mathrm{~cm}$, ass. centro inferior 1972. Disponível em: <http://www.tntarte.com.br/tnt/imagens/leiloes/2005_setembro/dscf3568.jpg>. Acesso em: 13 de Agosto de 2007. Rosina Becker do Valle (RJ, 1914-2000) - Começou a pintar por lazer, em 1955. Estudou na escola do Museu de Arte Moderna do Rio de Janeiro, sendo aluna de Ivan Serpa. Participou do Salão Nacional de Belas Artes entre 1967 e 1969, e da Bienal de São Paulo em suas $\mathrm{V}$ e VII edições. Seu trabalho enfoca principalmente o folclore, as florestas e os santos. Tem obras no Musée d'Art Naïf de L'Île de France, nos Museu de Arte Moderna de Hamburgo e de Buenos Aires, além de reproduções em livros editados no Brasil, Suíça, Inglaterra e França.

${ }_{126}$ Obra de autoria de Dag França. Disponível em: < http://www.mundim.net/Amigos/Galeria/Dag/Dag04x.jpg>. Acesso em: 08 de Julho de 2007. Dagmar Teixeira França - nasceu no município de Santa Cruz de Goiás, GO. Iniciou sua carreira como autodidata, freqüentou o atelier do professor Eliezer Ricardo, em Goiânia. Retrata o interior brasileiro, com mais ênfase o interior de Goiás e manifestações folclóricas regionais. 


\section{OS AVATARES PRESENTES NAS ICONOGRAFIAS COMO PROCESSO COMUNICACIONAL DAS FOLIAS DE REIS}

\subsection{Avatar}

A dinâmica de coexistência de diferentes culturas no mesmo território é um fenômeno que se tornou recorrente na contemporaneidade. Os processos midiáticos interligaram não só diferentes culturas de um mesmo país, como introduziram significações e termos utilizados em culturas distantes, antigas, tornando-as próximas no tempo presente.

No processo histórico de formação da cultura brasileira houve vários momentos em que o Oriente e o Ocidente se cruzaram, criando uma absorção de termos e conceitos que se perderam de sua origem, como nas manifestações do início do barroco com a inserção das chinesices, elementos estéticos comuns deste período.

Atualmente, com o processo de globalização das informações e a abertura do mercado e consumo imposto pelo neoliberalismo, elementos de diferentes culturas foram apropriados e passaram a circular com muita intensidade nas diversas comunidades do país chegando a perder seu sentido original.

Nesse sentido, a palavra avatar, transposta do sânscrito, é utilizada na atualidade pelos meios midiáticos, principalmente os digitais, para descrever um personagem em uma realidade virtual. $\mathrm{O}$ avatar criado carrega um conjunto de expressões, atitudes, vivências, objetos que compõem um 
mosaico comportamental e visual na forma de um personagem virtual, que possui, também, a essência de seu criador, muitas vezes manifestada de forma inconsciente. O avatar virtual se materializa através de uma linguagem técnica bits, bytes, pulsos, elétrons, representação visual gráfica com características e subjetividades humanas. Desta maneira o avatar é a composição gráfica visual investida da personalidade e da imaterialidade do humano - a personalidade ou a essência de seu criador.

A palavra avatar tem origem no sânscrito Avatara que significa descida, normalmente denotando uma das encarnações de Vishnu (Deus hindu). Pode ser também uma manifestação corporal de um ser imortal, por vezes até do Ser Supremo, além de significar transformação, transfiguração, metamorfose, incorporação da mesma essência de um ser divino presente em diferentes formas. Na cultura sânscrita, o avatar é incorporação, encarnação do espírito do deus Vishnu em várias formas e em diferentes tempos. Essa encarnação é a forma material que o Deus possui para se comunicar com os mortais; essa presença concreta e real faz com que a essência divina se torne parte integrante da vivência dos pertencentes da cultura sânscrita, bem como de outras culturas onde, de outras maneiras, exista uma realidade avatártica. Deste modo, os avatares sempre serão as manifestações concretas da essência divina em diferentes momentos da história das civilizações e de diferentes formas.

Na tradição Hindu, o deus Vishnu, se manifesta em diferentes avatares e são descritos em várias versões, nelas o número de avatares varia de seis, dez ou vinte e três, sempre sendo uma das manifestações concretas do deus Vishnu, que compõe a trindade máxima do panteão da mitologia 
védica (Trimurti) - Vishnu, Brahma e Shiva; Brahma cria, Vishnu mantém e Shiva transforma. Desse modo, Vishnu é entendido como o gerador da manutenção e preservação do universo. A versão mais recorrente no hinduísmo védico é a seqüência de dez avatares, descrita como sendo: “Matsya (o peixe), Kurma (a tartaruga), Varaha (o javali), Narasimha (meiohomem e meio-leão), Vamana (o anão), Parashurama (o brâmane), Ramachandra (o rei), Balarama (Krishna), Buddha e Kalki (o mantenedor da religião, senhor do universo)".

Segundo Caes (2006), o filósofo e místico Sri Aurobindo Ghosh, citado por D’AS, explica que a metáfora dos avatares descreve a evolução e o sentido da vida, uma parábola da evolução da vida no planeta:

[...] Primeiro vem o avatar do peixe, depois o animal anfíbio entre terra e água, em seguida o animal terráqueo, depois o avatar do homem-leão constituindo a ponte entre o homem e o animal, depois o homem como anão, pequeno, não desenvolvido de físico, mas contendo em si a divindade e tomando posse da existência, depois os avatares rajásico, sátvico e nirguna, levando o desenvolvimento humano do homem rajásico vital para o homem mental sátvico e daí para o super-homem supra-mental. Krishna, Buda e Kalki formam os três últimos estágios, os estágios do desenvolvimento espiritual. Krishna abre a possibilidade da mente superior; Buda tenta projetar para o além, para a libertação suprema, mas esta libertação é ainda negativa, não retornando à terra para completar positivamente a evolução; Kalki está aí para corrigir isto trazendo o reino divino para a terra e destruindo as forças de oposição de Asura. A progressão é fascinante e inequívoca. (D’AS, 1993, p. 92).

No Hinduismo, é Krishna quem conta a história dos avatares, encontrada no capítulo quarto do "Bhagavad Gita"; no texto, a dimensão do espaço e tempo também é descrita pelas manifestações divinas do Krishna. Assim, o deus se relaciona diretamente com os homens. 
Conheço todas as minhas vidas; tu não conheces as tuas, ó fustigador do inimigo. Ainda que Eu exista sem ter nascido, que Eu seja eterno, ainda que Eu seja o Senhor dos Seres, recorro à Minha natureza essencial e adquiro feição externa por Meu próprio poder misterioso. Pois sempre que a retidão se mostra em definhamento, ó filho de Bhárata, e a iniqüidade se manifesta, Meu Espírito aparece na terra. Para a proteção dos bons, e para a destruição dos malfeitores, para dar firme apoio aos justos, Venho a este mundo em todas as eras. Quem conhece meu nascimento e Minhas ações maravilhosas como realmente são, ao deixar o corpo, ele não volta para renascer; é para Mim que ele vai, Arjuna! (ELIADE, 1995, p.347).

Portanto, os avatares são apresentados de diferentes formas em diferentes momentos da evolução do homem hindu e carregam a mesma essência do deus Vishnu.

Em outras culturas e religiões, também é recorrente a idéia da materialização dos deuses para efetivarem um contato com os homens. Essa materialização pode apresentar-se de muitas maneiras, como a encarnação de deuses na forma humana, animal, vegetal ou através de objetos.

Entendendo esses elementos como elementos avatárticos que possuem o sentido do transcendente, do divino, eles se apresentam com características próprias em diferentes regiões e culturas, mantendo a singularidade cultural que as mesmas regiões lhes impõem.

Nas Folias de Reis, alguns elementos como as bandeiras, os palhaços, as máscaras, a montagem do presépio, os arcos, o banquete e a própria espacialidade criada nas realizações das festas podem ser entendidos como avatares da espiritualidade das Folias.

Tomando a bandeira como exemplo, elas sempre foram elementos materiais que simbolizaram o poder, a divindade ou a essência do que representavam; sofreu mudanças ao longo do tempo, mas continuou a representar e a materializar o poder e a essência de algo, como a identidade 
de um povo. Desta forma, a bandeira, nas folias, materializa o elemento divino; é através dela que o elo entre o divino e o terreno é estabelecido; por isso, em todas as cerimônias de Folias de Reis, ela se faz necessária. Na pesquisa de campo realizada, foram encontradas diferentes bandeiras em tamanho, material de confecção, cores e também o emprego de diferentes técnicas para sua elaboração; mas o sentido de ser elo entre o divino e o terreno é reconhecido e respeitado em todas as companhias estudadas. Ver foto 4.11 do capítulo quatro.

A necessidade de se aproximar do modelo idealizado do mundo divino é percebida na forma como os foliões representam o sagrado na bandeira - nela são incorporadas características estéticas próprias de cada comunidade.

$\mathrm{Na}$ bandeira da Folia de Ribeirão Grande, Ourinhos, a representação do bairro rural onde a Festa acontece é detalhadamente próxima da espacialidade real da comunidade. Quem olha para a imagem da bandeira, imediatamente pode reconhecer as características geográficas do bairro. Assim, o sagrado manifestado na bandeira é a imitação da espacialidade daquela comunidade. E, a cena da Natividade, descrita na Bíblia, pode ser compreendida pelos foliões como acontecendo realmente no bairro onde a Festa se realiza. A bandeira de Ourinhos exemplifica a necessidade dos rituais e dos objetos ritualísticos procurarem aproximar-se e imitar a vida dos deuses, bem como retroceder ao tempo sagrado inicial. 


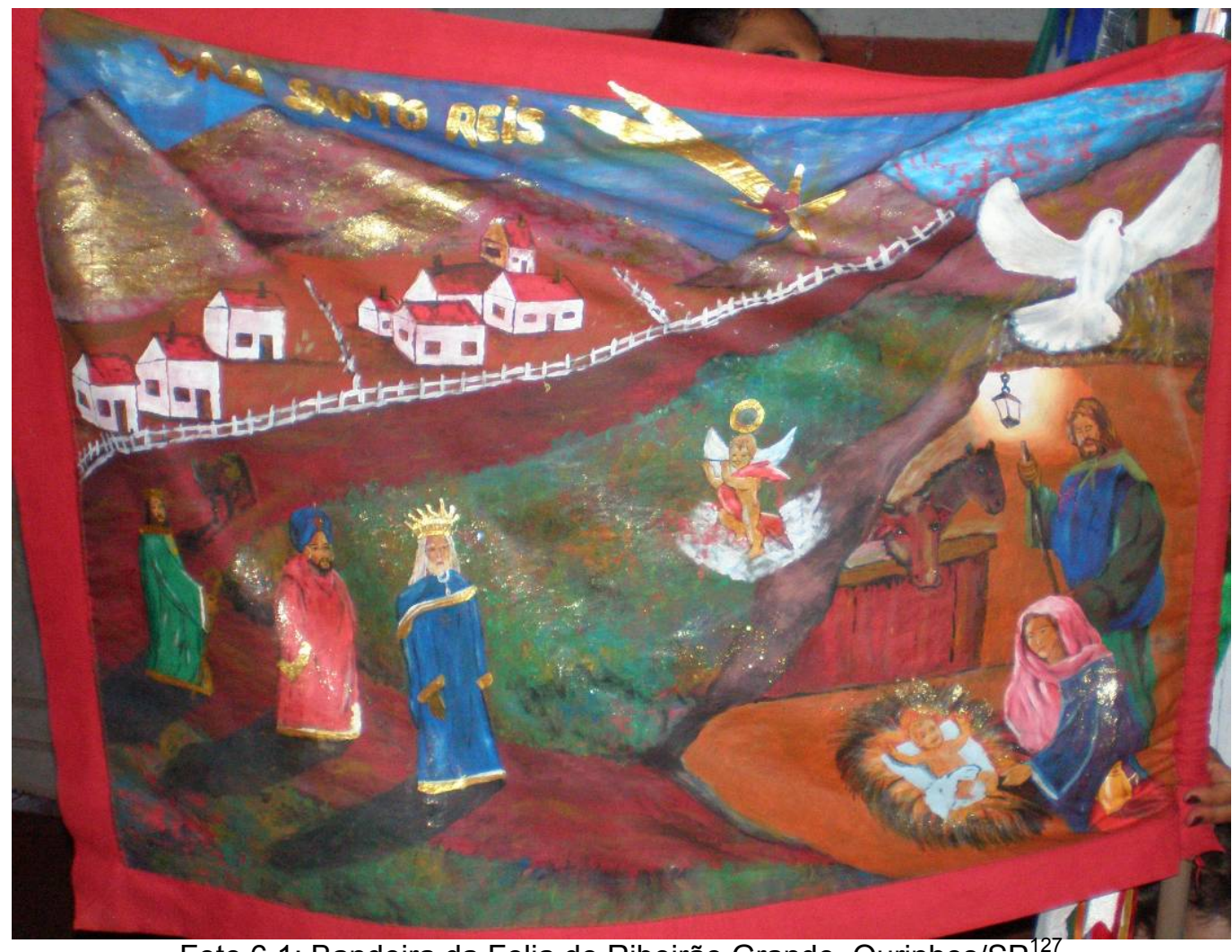

Foto 6.1: Bandeira da Folia de Ribeirão Grande, Ourinhos/SP

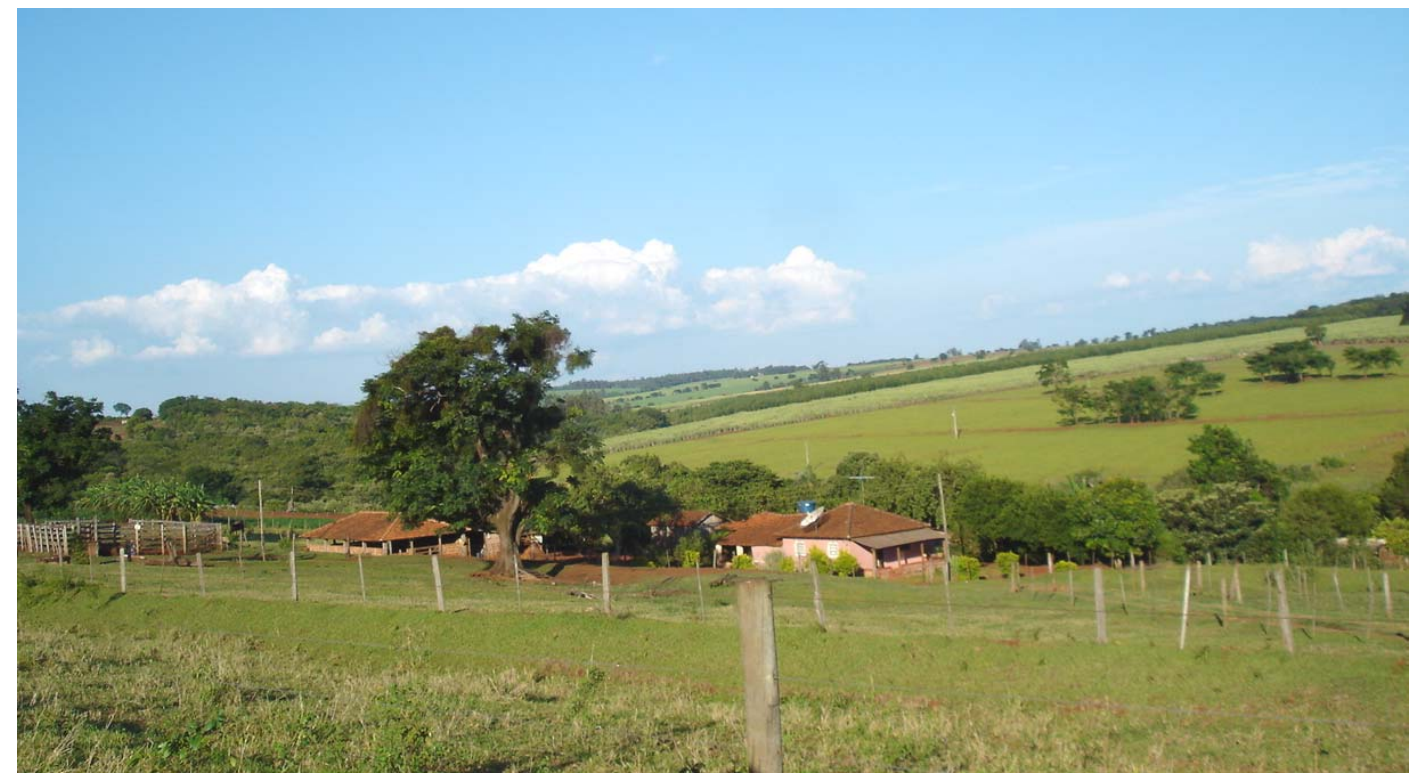

Foto 6.2: Bairro de Ribeirão Grande, Ourinhos/SP ${ }^{128}$

${ }_{127}^{127}$ Foto da autora.

128 Idem. 
Sendo assim, montar os presépios, levar a bandeira, levantar o mastro e os arcos pode ser entendido como avatares, que possibilitam repetir e reviver os acontecimentos sagrados da Natividade e estabelecer um elo com o nascimento Divino e com as epifanias. Por isso, os rituais das Folias e os elementos visuais que as caracterizam são sempre mantidos em sua essência, mesmo quando os grupos se apropriam das facilidades tecnológicas da atualidade. Por conseguinte, os elementos iconográficos das Folias são entendidos, neste trabalho, como elementos avatárticos.

Em diferentes épocas, nas diferentes culturas, o mundo sempre esteve dividido entre dois domínios - um sagrado e outro profano que transitam entre o imaterial e a materialidade. Portanto, a sedimentação dos traços culturais é elaborada a partir das explicações dadas para esses fenômenos do sagrado e do profano, do material e do imaterial, criando um universo habitado por deuses ou espíritos, que se materializam ou se manifestam de diferentes formas, desde elementos pertencentes às características geográficas de uma região (montanhas, vales, rios, árvores) a objetos elaborados pelos próprios homens (máscaras, estátuas, templos), desenvolvendo normas sociais para vivenciar esse sagrado (ritos, crenças, lendas, cantos). Desta maneira, as performances ritualísticas perpetuam a essência do sagrado através dos tempos, e são sustentadas, quase sempre, por objetos ritualísticos manufaturados, como a bandeira, no caso das Folias: presença avatártica que percorreu o tempo e continentes até a região estudada. 


\subsection{Manifestações Iconográficas das Folias de Reis}

Para o visitante de uma Festa de Reis, a visualidade encontrada está muito próxima das festas populares da atualidade; mas, ao deter o olhar com mais atenção, pode-se identificar diferentes elementos visuais que remetem para uma plasticidade de exuberância de formas e cores, como as bandeiras, as flores, os palhaços, os altares. Esta plasticidade, presente nas festas populares e religiosas do país, faz emergir um universo estético próprio, onde técnica e fazer artístico se confundem com a dimensão mágico-religiosa do evento, não podendo ser vista somente como atividade artística, mas geradora de uma plasticidade própria que caracteriza a estética encontrada nas culturas populares que exibem uma "beleza" única.

A plasticidade e a estética das festas das culturas populares estão imbricadas de tal forma que não podem ser separadas e, portanto, não podem ser divididas em categorias estéticas. Essa divisão ou apreciação é feita a partir do olhar externo, do olhar acadêmico e hegemônico ou quando se deslocam os objetos ritualísticos das festas para serem apresentados em outros contextos, como: apresentação em teatros, escolas, exposições em museus ou até mesmo, em exposições fotográficas ou em documentários; também, quando esses elementos são apropriados pelos meios massivos de comunicação para caracterização da "brasilidade", como nos folders turísticos, cenas de novela, minisséries ou revistas sobre moda, decoração, artesanato e turismo.

As manifestações plásticas das festas não podem ser entendidas sem antes serem compreendidas dentro de seu contexto gerador; 
portanto, saber da origem, do sentido de sua espacialidade, evolução histórica e do contexto cultural em que estão inseridas sempre se faz necessário. Também não é possível compreendê-las sem antes saber das implicações na dimensão sagrada da qual fazem parte. Para o pesquisador das culturas populares, não só os objetos são entendidos como manifestações plásticas, mas também a utilização e transformação do espaço tornam-se elementos estéticos, como as performances nele realizadas.

Do mesmo modo, os elementos plásticos são perpetuados pelo sentido ritualístico das festas e, para se manterem os rituais, é necessário existir uma transmissão do conhecimento do sagrado neles contidos. Surge assim, uma memória coletiva que preserva os códigos da dimensão do sagrado através da confecção e elaboração dos elementos simbólicos que os caracterizam.

A memória coletiva é preservada e transmitida pelas imagens visuais mantidas nas festas, bem como pelas imagens criadas pela oralidade. Quando a memória é representada e visualizada, ela é transmitida e, portanto, é preservada. Neste contexto, a memória que é construída nos núcleos sociais das culturas populares subalternas é coletiva. Para ser preservada, a memória necessita ser compartilhada, deixar de pertencer a um único indivíduo e passar a pertencer a um grupo. Os fazeres artísticos e as manufaturas elaboradas nas comunidades populares registram sua própria memória, o enraizamento da comunidade em sua própria espacialidade e, conseqüentemente, explicitam tradições e identidades culturais.

São nas diferentes linguagens artísticas que as memórias das culturas populares subalternas são perpetuadas e as tradições culturais 
mantidas. E são, também, as performances simbólicas que legitimam as práticas ritualísticas das festas populares, como os gestos, as danças, os cantos, as músicas as cerimônias e celebrações, os objetos e espaços consagrados e sagrados.

Durante as pesquisas nas Festas de Reis, analisando as diferentes manifestações que delas emanam, foi possível mapear, através de seus rituais e objetos simbólicos, as fontes heurísticas de sua origem e compreender a importância das festas para agregar e solidificar características culturais que dão sentido às comunidades que as promovem. Nelas, intrincadas operações de convivência são explicitadas e a convivência com diferenças desencadeadas. Desta maneira, as festas são atividades coletivas, não por reunirem um número significativo de indivíduos, mas porque, são nelas, que se exprimem os desejos do grupo, que muitas vezes contestam as convenções sociais locais, exprimindo os anseios da comunidade, através das diferentes composições visuais, principalmente pelos aspectos iconográficos.

\subsubsection{A espacialidade como iconografia}

Nas festas religiosas, a sacralização do espaço para sua realização remete para o surgimento de um espaço virtualizado, um duplo, que atua no espaço geográfico conhecido pela comunidade. Neste sentido, o espaço da festa e das manifestações religiosas não é só um espaço geográfico, é um espaço tornado sagrado para que se desencadeiem ações ritualísticas. É preciso transformá-lo, e essa transformação é indicada pelos 
elementos iconográficos depositados e incorporados ao espaço geográfico constituído, originalmente, na comunidade.

O espaço sacralizado pode ser entendido, neste trabalho, como um espaço avatártico da religiosidade popular. Normalmente, espaço geográfico e espaço religioso são distintos, porém, não existem atividades ritualísticas religiosas sem uma delimitação espacial e sem uma caracterização visual para delimitar o local onde o sagrado se manifesta.

Nas Folias, podem-se observar diferentes rituais que ocupam e sacralizam diferentes espaços, como: o giro, os altares para abrigar os presépios e as bandeiras, os espaços da cantoria delimitados pelos arcos, os espaços delimitados para o banquete (almoço), a sacralização das casas que recebem a bandeira, o caminho percorrido pelas Folias no giro e, conseqüentemente, dos bairros em que a Folia transita.

Desde o culto aos mortos, nos primórdios das civilizações, aos ritos de recriações das características epifaníacas das manifestações divinas, como no caso das Folias, que recriam, através do uso de diferentes espaços geográficos, o texto bíblico do nascimento de Cristo, se faz necessário, compreender que a sacralização das Folias abrange não somente um local, mas diferentes configurações geográficas e diferentes configurações visuais para consagrar e sacrificar espaços necessários para sua realização. Por isso, não é possível entender a dinâmica das Folias sem compreender, na totalidade, os diferentes rituais que as compõem, como o início do giro, a seqüência da visitas, o pouso, o espaço da festa. Assim, os espaços sagrados, após serem configurados, passam a exercer influências sobre a dinâmica cultural das comunidades onde estão inseridos. 
As Folias criam diferentes hierofanias ${ }^{129}$, por distintos rituais em diversos espaços, com vários objetos, mesclando, em sua manifestação, o profano e o sagrado, o público e o privado, o Catolicismo Popular e o Catolicismo Românico. Promovendo uma repetição cíclica que ordena as necessidades espirituais das comunidades onde acontecem e que são renovadas, anualmente, independentemente da necessidade de deslocamento dessa comunidade para um espaço sagrado, constituído e fixo. Sua dinâmica ritualística desenvolve o contrário: transforma os espaços existentes em espaços sagrados. Portanto, as Folias podem ser flexíveis quanto ao espaço em que se realizam, adequando-se às necessidades das comunidades que as promovem. Essa mobilidade e deslocamento propiciam, na atualidade, sua transferência e adaptação da origem rural para as áreas urbanas, sem esvaziar sua essência.

Por essa mobilidade no espaço, é possível entender a permanência das Folias como uma das festas de maior incidência nas comunidades populares e/ou subalternas das cidades e do sudeste do país. A geografia que analisa os espaços míticos elenca alguns espaços sagrados como fundamentais para a realização do fenômeno religioso, tais como: um local para manifestação do sagrado, que muitas vezes desencadeia a construção de templos, espaços fixos, que determinam a organização nas comunidades de um espaço sagrado e de um espaço profano, de um espaço público e de um espaço privado do sagrado. Uma vez que nem todos pertencem a esses espaços, surgem as rotas de peregrinação como via de

\footnotetext{
129 "O homem toma conhecimento do sagrado porque este se manifesta, se mostra como qualquer coisa de absolutamente diferente do profano. A fim de indicarmos o ato da manifestação do sagrado propusemos o termo hierofania." (ELIADE, Mircea. O sagrado e o profano, 1992).
} 
encaminhamento das comunidades e das culturas ao encontro de um espaço sagrado. Desta maneira, a sacralidade dos espaços pode atingir pequenos territórios ou grandes regiões, ou serem estendidos para grande escala, como a navegação de rios, escalação de montanhas, ou a construção de caminhos considerados sagrados. Percebe-se, nas Folias de Reis, a reconstrução e a incorporação desses diferentes espaços onde tanto os espaços geográficos em que se realizam quanto os indivíduos neles inseridos partilham do sagrado.

Essa necessidade de caminhar pelo sagrado e ao encontro do sagrado fez surgir no catolicismo popular os rituais das grandes procissões festivas, como o é, também, o giro das Folias. Procissão significa marcha para frente, e caracteriza um ritual móvel, com início e fim em espaços sagrados.

As procissões foram atividades sociais e religiosas de grande vulto na Idade Média, principalmente na península ibérica. Tem origem como rogações para solicitar boas colheitas e também para dramatizar as comemorações como as da Semana Santa. No Brasil, chegaram com os portugueses e atingiram seu auge no período colonial, principalmente no Barroco. Na atualidade, destacam-se o Círio de Nazaré, em Belém, e a Procissão dos Navegantes, na Bahia, como forte expressão da religiosidade do povo brasileiro, assim como as procissões de Corpus Christi, da Semana Santa e de Santos Padroeiros que são acontecimentos de destaque em muitas comunidades.

Nas Folias, os espaços de início e de fim, são sacralizados a partir da montagem dos presépios e da presença da bandeira. $\mathrm{O}$ giro das Folias preenche um espaço que as procissões não alcançam, que é a 
sacralização de cada casa por onde passa, fazendo uma ponte entre os pertencentes da comunidade, suas casas e o Divino.

Da mesma forma, ao recriar uma espacialidade sagrada podemos transcender o tempo. O caminhar no sagrado e pelo sagrado remete os foliões e as comunidades para um outro tempo, o tempo da epifania, em que a memória e histórias são retomadas através de performances que tornam as Folias atemporais. A memória é constituída pelo desenrolar da vida; nela os hábitos, as características etnográficas e iconográficas criam especificidades de identidade capazes de transcender o tempo e o espaço, criando a identidade das comunidades. As Folias de Reis transitam por esses espaços identitários que permeiam a construção das manifestações das culturas materiais e imateriais nelas contidas. Deste modo, os espaços percorridos pelas Folias transformam-se em manifestações iconográficas para os foliões e para a própria comunidade onde as Folias se deslocam.

\subsubsection{Performance das Folias de Reis como iconografia}

[...] Performances afirmam identidades, curvam o tempo, remodelam e adornam corpos, contam histórias. Performances artísticas, rituais ou cotidinas - são todas feitas de comportamentos duplamente exercidos, comportamentos restaurados, ações performadas que as pessoas treinam para desempenhar [...] (SCHECHNER, 2003. In: O Percevejo, p.27) ${ }^{130}$.

A performance envolve diferentes linguagens artísticas: a visual, a musical, a dança, o teatro, e as provenientes da atualidade, como o

\footnotetext{
130 RICHARD SCHECHNER é professor da New York University, diretor de teatro e fundador e editor da revista The Drama Review, publicada pela NYU. Entre os seus livros se destacam: Environmental Theater, Hawthorn Books, Inc.1973; Performance Theory, Routledge, 1977; The Future of the Ritual, Routledge, 1993; Between Theater and Anthropology, University of Pennsylvania Press,1985; Performance Studies, An introduction, Routledge, 2002.
} 
cinema e o vídeo. Como linguagem, surge a partir de propostas artísticas elaboradas no início do século passado e atinge seu maior desempenho na atualidade. Em dicionários, a palavra em si remete para a atuação ou apresentação em público; porém, como linguagem, pode ser entendida, desde os remotos rituais tribais, como conjunção de diferentes linguagens e adquire maior destaque a partir da Idade Média, quando foi apropriada pelos grupos populares do teatro de rua.

Performance, então, pode ser ações conjuntas de diferentes linguagens que integram e interagem com um grupo social. Ela não é um acontecimento único de um indivíduo isolado; pode ser desencadeada por um único "ator", mas sempre supõe o uso de um coletivo, porque implica em "ator" e "espectador"; é própria de múltiplas linguagens e de um coletivo.

Quando a performance está vinculada às culturas populares, remete a uma sociabilidade comunitária que faz emergir os traços identitários do grupo - traços estes vinculados as suas manifestações históricas, culturais e simbólicas.

$\mathrm{Na}$ atualidade, as performances podem ser estudadas como possuidoras de diferentes gêneros. Neste trabalho, que também entende as Folias de Reis como manifestação performática, a realidade social dos grupos é reproduzida nas Folias. Nesse sentido, pode-se utilizar o termo "antropologia da performance", proposto por Victor Turner (1988), que a distingue entre performance social e performance estética. Por performance social ele entende como sendo os ritos, as peregrinações religiosas, os dramas e tramas sociais; e por performance estética as manifestações teatrais, danças, músicas destinadas à diversão e entretenimento individual ou coletivo. 
Assim, a "antropologia da performance" procura compreender os espaços simbólicos e as linguagens metafóricas que representam a realidade social, muitas vezes através de um jogo, em que vários papéis são estipulados e/ou invertidos, de forma criativa, propiciando momentos de conhecimento e autoconhecimento do grupo em relação a si mesmo e em relação às tramas sociais nas quais estão inseridos. Deste modo, os geradores das performances (ou ações simbólicas) se utilizam dos próprios traços identitários do grupo para dar sentido à sua própria coletividade.

Nesta perspectiva, o olhar iconográfico a partir da "antropologia da performance" consiste em compreender seus significados dentro das ações simbólicas imbricadas no contexto social onde se manifestam. Portanto, para o pesquisador, é importante compreender o olhar de quem faz e onde o faz, e então, partir da performance para compreender as diferentes realidades onde as representações performáticas estão inseridas. No caso das Folias de Reis, faz-se necessário compartilhar com os seus atores e espectadores tais atuações para compreender os diferentes sentidos que delas emanam; é necessário adentrar na cultura do outro.

Nas Folias de Reis, as outras linguagens estão intimamente ligadas aos elementos iconográficos. Essa predominância visual exige do pesquisador uma atenção específica; pois, para compreendê-la é necessário compreender toda a encenação visual que dela provém. Por exemplo: a figura do palhaço - com todo o conjunto de linguagens que o compõe (vestimenta, máscara, bastão, atitudes, danças e declamações) - não pode ser vista separadamente, assim como não pode ser vista sua atuação de forma isolada 
do amplo contexto das diferentes formas performáticas que compõem as Folias de Reis.

As atuações performáticas das Folias "são feitas de pedaços de comportamento restaurado, mas cada performance é diferente das demais, a festa é sempre em todos os anos, Folia de Reis, mas cada ano é uma nova e uma outra Festa. Primeiramente, [esses pedaços] podem ser recombinados em variações infinitas. Segundo, nenhum evento pode copiar, exatamente, um outro." (SCHECHNER, 2002). Nesta perspectiva, se entende as Folias como atividades avatárticas; nelas, as instâncias históricas e culturais em que são realizadas devem ser compreendidas a fim de entender as Festas da atualidade, não somente como ecos da memória de diferentes culturas, mas como manifestação única e do tempo em que está acontecendo.

As performances não acontecem apenas quando as manifestações plásticas interagem com outras linguagens; ocorrem quando há “ação, interação e relação. A performance não está em nada, mas entre." (SCHECHNER, 2002).

$O$ interesse em estudar as Folias como atividades performáticas advém do fato delas estarem inseridas em duas dimensões, a individual e a social (comunitária). Segundo Schechner (2002), as performances acontecem a partir de um "comportamento restaurado", que para ele representa a repetição de ações comportamentais que são presenciadas por um outro e que, conseqüentemente, neste fazer e ser visto, desencadeiam e preservam os ethos culturais.

Toda performance é uma atividade cultural dinâmica, refeita, reelaborada, reproduzida criativamente ao longo do tempo, e se estabelece 
através de experiências e interações sociais, sendo transmitida, principalmente, pela oralidade - comportamentos restaurados. Nas Folias, práticas semelhantes acontecem: os atores e espectadores se separam do cotidiano, transformando os processos sociais da comunidade em encenações dentro de conjunturas culturais específicas àquela mesma comunidade.

A performance das Folias evoca a memória, instiga à reflexão e remete para experiências que fazem parte da trajetória de vida das comunidades em que se inserem. E o que a performance realiza?

Segundo Schechner (2002), a performance tem como função ser um repositório de conhecimento e veículo de expressão, ou ainda, entretenimento e educação. Schechner cita sete funções da performance: "entreter; fazer alguma coisa que é bela; marcar ou mudar a identidade; fazer ou estimular uma comunidade; curar; ensinar, persuadir ou convencer; lidar com o sagrado e com o demoníaco". Nas Folias de Reis encontram-se todas essas categorias.

As Folias entretêm quando agregam em seus rituais atividades profanas, como as apresentações de catiras, nos encontros festivos e de confraternização antes dos giros; lidam com a beleza na elaboração das bandeiras, vestimentas, na preparação e confecção dos altares, na decoração das festas; marcam ou mudam a identidade dos componentes do grupo quando se fantasiam de reis, palhaços ou assumem a função de festeiros ou gerente ou assumem o papel de foliões; agregam a comunidade em torno de um objetivo comum - o almoço, o recebimento dos foliões, o preparativo da festa; curam quando, através da crença, vivenciam milagres, materializados principalmente nas fitas de agradecimento e solicitações depositadas nas 
bandeiras; ensinam quando transferem conhecimentos pertinentes à comunidade ou dos textos sagrados (Bíblia) ou das histórias de outras Folias, ensinam, ainda, a tocar um instrumento, a dançar e a cantar; persuadem ou convencem quanto à santidade dos Reis, opondo-se à Igreja romanizada e também quando insistem e persistem em se apresentarem em comunidades que não fazem parte de sua origem inicial; lidam com as dicotomias: bem e mal, sagrado e profano, quando comemoram uma epifania; revivem o desejo do mal em destruir o nascimento do Messias, através da figura de Herodes.

Nas atividades performáticas das manifestações populares, as funções acima descritas muitas vezes não perfazem toda esta somatória e podem aparecer algumas que se destaquem mais que outras ou estejam suprimidas.

Entender as Folias como atividades performáticas desencadeia um pensamento conceitual dialético em que a performance pode ser utilizada como ferramenta conceitual do como se pode examinar as coisas sem estar centrados em uma única ciência. Uma "ciência performática" manifesta-se quando, na atualidade, convive-se com novas linguagens que ainda reclamam fundamentações conceituais e teóricas para serem compreendidas, como os jogos online e seus avatares, ou, como no caso das culturas populares, onde é necessário um novo arcabouço teórico para compreendê-las na contemporaneidade.

Neste sentido, pode-se compreender que nas culturas populares muito das tradições transmitidas pela oralidade são exemplificadas e sustentadas a partir de atividades iconográficas performáticas: as manifestações avatárticas. Esta constatação se sustenta a partir dos registros 
encontrados das manifestações visuais que gravaram e registraram a presença do homem desde imemoráveis eras - as pinturas rupestres são os exemplos mais contundentes desta linha de pensamento. Mas, neste trabalho, as linguagens iconográficas também são entendidas como a representação espacial das Folias, a gestualidade, as danças e os objetos ritualísticos que as compõem. Ao usar a linguagem oral para nortear a construção de objetos visuais que sejam significativos e depositários da sacralidade de um grupo, está-se depositando neste objeto a memória coletiva do grupo e transformando este objeto em registro atemporal das tradições, no sentido em que Eric Hobsbawn (1984) utiliza - inventando tradições.

As representações visuais estão fortemente ligadas à construção cultural das sociedades. A oralidade carrega a acentuação dos regionalismos; mas é pelas comunicações visuais que as especificidades da espacialidade são reconhecidas, no sentido que Milton Santos usa e, portanto, as culturas são materializadas, concretizadas. É pela visualidade que se distinguem as múltiplas representações das culturas populares no país: a Folia de Reis, a Festa do Divino, a Congada, o Tambor de Crioula, o Carnaval com suas alas e estandartes e as Procissões Religiosas com seus estandartes e irmandades, possuem visualidades próprias.

A indústria do turismo, na atualidade, tem se utilizado desse mecanismo de reconstruir visualmente atividades culturais pertencentes a grupos subalternos para vender a idéia de nacionalismo, de brasilidade; essa utilização da indústria do turismo é o que se pode entender como geradora de um "público acidental", ou seja, aqueles espectadores de uma atividade performática que estão ali somente para presenciar ou se divertir a partir do 
evento, diferentemente de um "público integral", em que atores e espectadores se complementam e detêm os códigos de entendimento e compreensão do evento.

\subsection{Os Processos Comunicacionais nas Folias de Reis}

É nas diferentes relações comunicacionais que as atividades humanas são caracterizadas. A comunicação não é um fenômeno isolado, nem restrito à contemporaneidade; interage com as manifestações culturais de cada comunidade desde seus primórdios. Para entender os diferentes processos comunicacionais é necessário entender o local da cultura. Portanto, é necessário olhar para uma,

ancoragem territorial de inserção no local, já que é no lugar, no território que se desenrola a corporeidade da vida cotidiana e a temporalidade - a história - da ação coletiva, base da heterogeneidade humana e reciprocidade, características fundadoras da comunicação humana (BARBERO in MORAES, 2003, p.58).

$\mathrm{Na}$ atualidade, a velocidade com que as informações circulam criando uma macrocircularidade de informações está forçando os pesquisadores da Teoria da Comunicação a voltar sua atenção para o local.

[...] mesmo atravessado pelas redes do global, o lugar segue feito de tecidos das proximidades e das solidariedades. Isso exige que se esclareça que o sentido do local não é unívoco. Um é aquele que resulta da fragmentação produzida pela deslocalização que o global acarreta, e outra é a revalorização do local como âmbito onde se resiste (e se complementa) a globalização, sua auto-revalorização como direito à autogestão e à memória própria, ambos ligados à capacidade de construir relatos e imagens de identidade. (BARBERO in MORAES, 2003, p.58-59). 
Neste trabalho, procurou-se observar, nas comunidades estudadas, os processos comunicacionais que lhes permitem conviver e sobreviver no âmbito da comunicação globalizada.

Marcondes Filho (2004) afirma que "viver é estar comunicando, emitindo sinais, demonstrando participar do mundo". Neste sentido, em seu livro Até que ponto, de fato, nos comunicamos?, o autor propõe um outro conceito de comunicação: "Comunicação é antes um processo, um acontecimento, um encontro feliz, um momento mágico entre duas intencionalidades". Assim, foi com esse olhar que se procurou entender os processos comunicacionais dos participantes das Folias de Reis, um acontecimento, um encontro feliz.

A compreensão da origem das Folias e a observação das festas direcionaram o olhar para um acontecimento ímpar das Folias. Nelas, a intenção máxima é celebrar e pedir pela vida e é esta intenção que move seus participantes e desencadeia os múltiplos processos comunicativos presentes e observados nas festas.

É o que faz as Folias sobreviverem frente às "lógicas unificantes da globalização econômica [...] que mundializam a cultura" (BARBERO, 2004); é sua capacidade de "criação de um ambiente comum em que os dois lados participam e extraem de sua participação algo novo, inesperado, que não estava em nenhum deles, e que altera o estatuto anterior de ambos, apesar de as diferenças individuais se manterem" (MARCONDES FILHO, 2004, p.15). Foi nessa perspectiva que os processos comunicacionais ocorrentes nas Folias de Reis foram analisados. 
As culturas populares possuem uma concepção de mundo específica; nelas, as "Eras da Cultura", propostas por Santaella (2004), são explicitadas em sua totalidade, desde a era da oralidade à da cultura digital.

Então, como entender e os processos comunicacionais percebidos nas comunidades estudadas?

Foi possível percebê-los e compreendê-los a partir da proposta de Marcondes Filho (2004, p.16):

Comunicação tampouco é instrumento, mas, acima de tudo, uma relação entre mim e o outro e os demais. Por isso, ela não se reduz à linguagem, menos ainda à linguagem estruturada e codificada numa língua. Ela ultrapassa e é mais eficiente que esse formato, realizando-se no silêncio, no contato dos corpos, nos olhares, nos ambientes.

Por isso, foi possível perceber que as características avatárticas das Folias transcendem os meios e processos comunicacionais da atualidade $\mathrm{e}$ induzem as comunidades estudadas a desenvolverem uma linguagem comunicacional própria, que não está "subordinada às formas lingüísticas, pois há muitas outras formas de comunicação que vão além das linguagens [...]" (MARCONDES FILHO, 2004, p. 55).

Para Marcondes (2004), não podemos entender a comunicação somente vinculada às linguagens, como se vem estudando, pois assim, as análises dos processos comunicativos adquirem uma "operação cartesiana de divisão de real para melhor analisá-lo". Isto está vinculado ao positivismo, que trata os fatos culturais como objetos que podem ser decompostos e analisados separadamente, descaracterizando o fato comunicacional em si. Neste trabalho, foi necessário analisar as diferentes manifestações que estão imbricadas dentro das Folias, mas não somente suas partes separadas. Se fez necessário entender como esses processos são 
indissociáveis e como as Folias são compostas por múltiplas linguagens que se complementam para formar um todo orgânico e coerente, com vida própria. Não existe Folia sem música, sem dança, sem plástica, sem canto, sem palavras, sem ocupações espaciais.

Portanto, é exatamente nesta multiplicidade de linguagens que se desencadeia um processo comunicacional único, que não é afetado pelos processos globalizantes de comunicação. Em suas realizações, as comunidades até se servem desses processos, mas não dependem deles para existirem. "O sentido do mundo está fora da linguagem, ele está no ontológico e não no lógico." (MARCONDES FILHO, 2004, p.62).

Desta maneira, olhamos os processos comunicacionais dentro das próprias vivências culturais e em suas interações plurais, uma vez que diferentes elementos se interpenetram, influenciam-se e se transformam mutuamente, criando diferentes saberes culturais e artísticos e/ou recriando-os.

$$
\text { Então, os ethos culturais constituem processos }
$$
comunicacionais que se originam fora do oficial, fora do hegemônico, ou seja, na informalidade, na espontaneidade gestada em uma organicidade e organização próprias dos grupos subalternos que compõem as culturas populares, interagindo entre o individual e o coletivo, criando um processo comunicacional sui generis que tem sobrevivido aos acontecimentos históricos.

As culturas populares sempre existiram e conseguiram transmitir sua visão de mundo, independentemente dos processos hegemônicos e dos processos comumente entendidos como processos comunicacionais, pois "a comunicabilidade humana serve-se tanto do explícito quanto do implícito (que muitas vezes se contradizem), do jogo de 
representações cênicas, assim como das alusões diretas e indiretas a outras cenas passadas e fora do alcance." (MARCONDES FILHO, 2004, p.72).

Desta forma, os processos comunicativos percebidos nas culturas populares estudadas são avatárticos no sentido que:

A linguagem é na verdade muito mais ampla, mais complexa, mais profunda do que pretende a vã lingüística. Segundo Merleau-Ponty, ela é uma relação viva consigo mesma ou com os outros e ela não deve ser vista como meio ou instrumento; acima de tudo, ela é uma manifestação, uma revelação do ser íntimo e da ligação psíquica que nos une ao mundo e aos nossos semelhantes.

[...] é o lugar onde a unversalidade do sentido e da percepção se reconhecem como tal. É lá que o para-mim e o para-os-outros tornam-se uma única e mesma coisa.

[...] a linguagem e seus termos são a modulação da existência. Uma obra de arte nos ensina a ver, e, por fim nos faz pensar como nenhuma obra analítica o faria. (MARCONDES FILHO, 2004, p. 72 73).

Portanto, podemos entender que a oralidade que preserva as culturas populares é ancorada em suas representações visuais (avatares iconográficos). Para Merleau-Ponty, citado por Marcondes Filho (2004), "a visão situa-se antes da representação, ou seja, um pintor não reproduz o mundo, comunica-se com ele, através da tela ele deixa o mundo passar". Assim,

[...] O estar no mundo do pintor é a abertura libertadora que a sua obra provoca, ressemeando o mundo com a interioridade vidente dos homens para elevá-los ao nível de uma presença real. Não se vê uma tela, que permanece fixa em seu lugar, vê-se por meio dela.

[...] Resumindo: nós e o mundo formamos uma única carne, as coisas passam por dentro de nós e nós por dentro das coisas, somos ativos e passivos. Abro-me aos fenômenos do mundo, mas estes só existem quando eu os vivo. (MARCONDES FILHO, 2004, p. 80).

Ao pressupor que nas culturas populares os processos comunicacionais vão além daquilo que as propostas teóricas da contemporaneidade apontam e, usando como subsídio as considerações de Marcondes Filho (2004, p.93), entendeu-se que "na linguagem estruturada, a 
comunicação torna-se ritualizada, não diz nada, por isso buscamos outras formas, menos codificadas, menos ineficazes". Neste trabalho, foi necessário um outro olhar para os processos comunicativos das camadas subalternas, e este outro olhar indicou olhar primeiramente como os grupos estudados estabelecem um vínculo com o sagrado, como e quando é manifestada a necessidade de sacralizar um espaço e como um início de ano vivenciando os rituais da Folia cria um lugar de pertencimento.

"Para se captar o mundo jamais podemos nos prender apenas às palavras. Além de elas serem uma forma impessoal, neutra, vazia de sentimentos e de vivências pessoais, elas são um meio pouco confiável de comunicação." (MARCONDES FILHO, 2004, p. 93). Nas Folias a comunicação entre seus pares se dá através de gestos, olhares, trocas afetivas, respeito aos preceitos hierárquicos, respeito aos símbolos e códigos de conduta de cada companhia.

"Mas o mundo me olha por muitos outros canais. O que eu sou, de fato, não é transmitido pela linguagem." (MARCONDES FILHO, 2004, p. 93). A confiança no grupo, a participação de todos indistintamente da origem social, a aceitação da contribuição de todos para a festa, a solidariedade desencadeada, criando uma condição de pertencimento e canal comunicativo entre as comunidades estudadas - que vai além dos processos massivos de informações a que estão submetidos, e que vai além das deformações e informações equivocadas que lhes são impostas sobre seus modos viventes o almoço servido a todos, o compartilhar o excedente de sua produção, as doações para a festa, o acolhimento a todos são outros canais por onde flui essa comunicação popular subalterna. 
"Há comunicação quando eu consigo fazer com que o outro atinja a mesma faixa de freqüência de meu pensamento, entre em minhas idéias, as sinta como eu". (MARCONDES FILHO, 2004, p. 99). A cantoria na Folia de Reis é um momento que exemplifica como o processo acima se dá: o Embaixador elabora de improviso os versos, que são repetidos na seqüência pela segunda voz, e finalizados por todos os músicos e quase todos os foliões. Acontece um processo comunicativo, harmônico e único que, para os desavisados, pode parecer que foi ensaiado há muito tempo, mas que sempre é feito de improviso durante os giros dos foliões.

\footnotetext{
Mas isso jamais se realiza de modo imediato. Por isso, o processo comunicativo deve ter condições de maturação, é um trabalho que pressupõe certo caminhar juntos, na constância, na insistência; um trabalho continuado e intencional em transmitir ao outro, de fazê-lo sentir-se em nós. (MARCONDES FILHO, 2004, p. 100).
}

A presença na permanência por sete anos na Folia é um processo de maturação que permite que os códigos de sua estruturação e elaboração sejam conhecidos por todos os componentes do grupo, assim como pela comunidade e, principalmente, esse processo comunicacional de pertencimento e de permanência é mantido pela presença indiscriminada de jovens e adultos, pela participação efetiva dos mais velhos da comunidade, pelas presenças feminina e masculina, todos cientes de seu papel na Folia, mas, principalmente, pela presença das crianças, filhos e netos da Folia, que encontram no "foliar", uma atividade lúdica e de pertencimento, uma atividade que lhes permite encontrar seu lugar naquela comunidade e reconhecer-se nela, - mesmo convivendo com todas as influências que chegam continuamente de fora. Enfim, pela presença "avatártica" de sua iconografia e pela sua capacidade de se reinventar. 
Como observado nas pesquisas para este trabalho, as Folias explicitam elementos herdados de épocas e regiões distantes, que permanecem inalterados em sua essência, independentemente de serem muitas vezes apresentados com outras roupagens e em uma região como a de Ourinhos, estruturada recentemente, filha dos processos globalizantes e hegemônicos de formação e valorização dos fazeres culturais, processos que engoliram e suprimiram muitas outras tradições e modos viventes do que podemos chamar de brasilidade. O caminhar no Giro, o cozinhar juntos, o orar com a sua comunidade, o brincar, o cantar, o comer todos à mesma mesa são esse "caminhar juntos, na constância, na insistência; um trabalho continuado e intencional em transmitir ao outro, de fazê-lo sentir-se em nós".

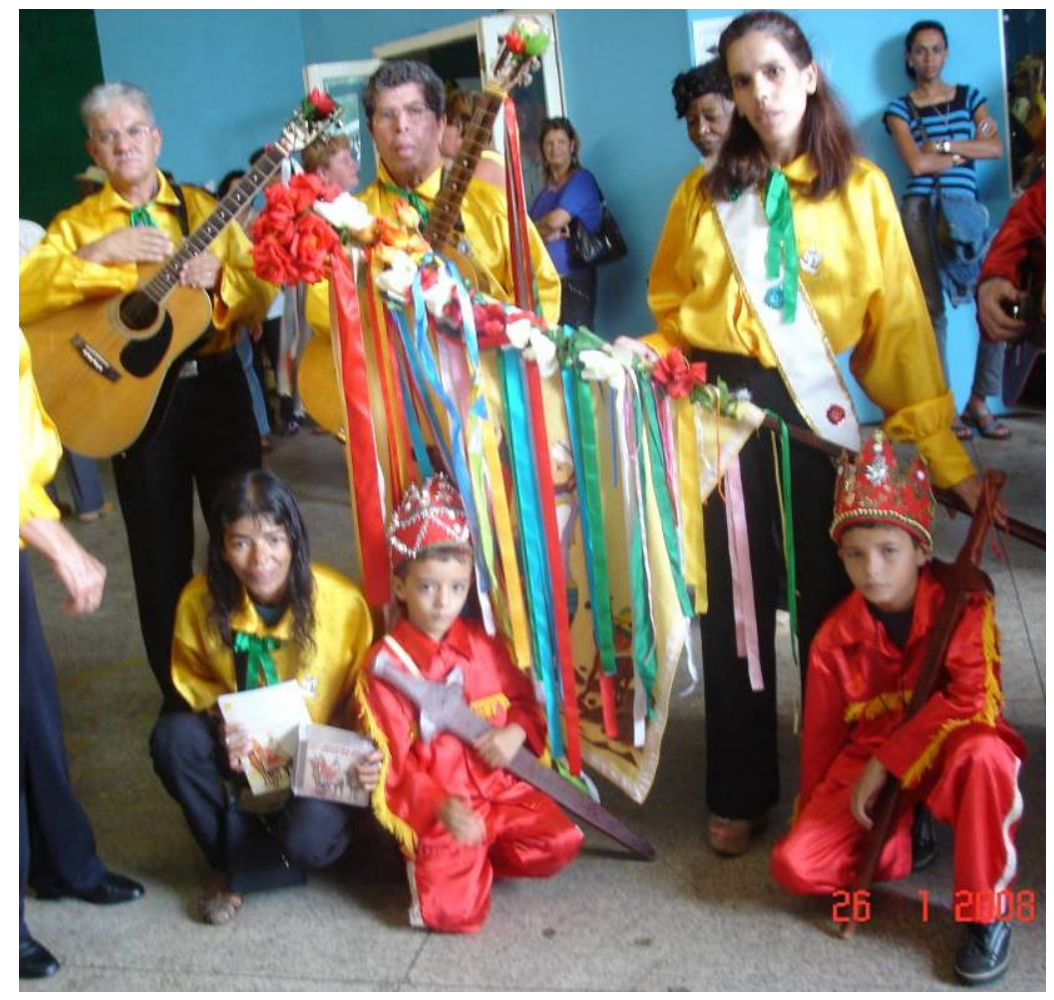

Foto 6.3: Companhia Mensageiros da Paz. Encontro de Folias de Assis/SP ${ }^{131}$

${ }^{131}$ Foto da autora, 2008. 


\section{CONCLUSÕES PRELIMINARES}

Para apresentar as considerações finais deste trabalho, foi necessário entender as Folias de Reis como portadoras da essência da formação da brasilidade, tanto em seus aspectos religiosos como profanos. E, também, como significativo sistema de comunicação subalterna. Foi necessário compreendê-las como patrimônio imaterial do país.

Nesse sentido, ao entender a Folia de Reis como patrimônio imaterial, está-se propondo que não é possível engessar sua prática no tempo e restaurar suas apresentações. O patrimônio imaterial é orgânico, vivo, se refaz e se transforma. Preserva-se um edifício, uma cidade, uma obra de arte; uma Festa tem de ser vivenciada para ser compreendida. Portanto, as Festas Populares permitem desenvolver pesquisas e estudos; mais ainda: implementar considerações metodológicas para que, através desses processos cognoscitivos, possa-se contribuir para sua permanência como estruturante dos valores da cultura brasileira.

O poder público e as instituições de preservação do patrimônio cultural do país não podem preservar uma festa; ao fazê-lo, está-se descaracterizando sua essência. A única forma de promover sua continuidade é compreendê-la em sua totalidade. Isso implica compreender sua origem, o local onde acontece e, enfim, os seus múltiplos elementos atuando dialeticamente. Foi essa tarefa que o trabalho apresentado iniciou. Reconhecer as festas como bens culturais dinâmicos, que dão sentido às comunidades onde acontecem. Compreendê-las como documentos visuais e, portanto, documentos históricos do ethos da região onde estão inseridas e da própria 
brasilidade. Nelas, as memórias individual e coletiva são ativadas e sempre revividas; as festas são documentos coletivos, públicos e socializados com todos, portadoras das culturas subalternas e hegemônicas.

Ao compreender uma festa profana ou sagrada e registrar suas performances, está-se dando voz aos seus protagonistas, atores e espectadores. Também está-se dando voz as suas crenças e registrando suas manifestações simbólicas, como ainda abrindo espaço para que outras manifestações de características imateriais sejam estudadas e difundidas nos meios hegemônicos de divulgação do conhecimento.

Pode-se ainda afirmar que nas comunidades onde o estudo foi elaborado, sua continuidade está assegurada, pois elas - as festas - se mantêm, independentemente dos avanços da sociedade capitalista e do "novo colonialismo". Mesmo incorporando elementos que, a princípio, pareçam impostos ou estranhos à comunidade onde ocorrem, suas características avatárticas se conservam.

O que tornou-se evidente pelo estudo de campo foi que as manifestações provenientes das culturas subalternas, principalmente as Festas Populares, estão imbricadas no cerne, na natureza das comunidades estudadas. E, portanto, as tradições fazem parte do cotidiano destas comunidades. É a cultura erudita, a cultura da academia, que necessita das culturas populares subalternas para compreender a si mesma e dar sentido as suas proposições quanto ao que se refere à cultura tradicional brasileira.

Tradição vem do latim, traditio, entrega; é o ato de transferir um conhecimento empírico, técnico ou concreto para o outro ou outros. Isso caracteriza o conhecimento passado de pai para filhos ou dos mais velhos para 
os mais novos; portanto, a tradição está presente em todos os estratos sociais, faz parte do dia-a-dia das diferentes comunidades sociais e culturais. A tradição está sempre tecendo uma trama indissolúvel. Mas, nas culturas hegemônicas, as tradições estão mais ameaçadas, pois, nelas, as influências deformadoras da globalização se fazem presentes com mais insistência.

O processo de comunicação das tradições subalternas é eficaz, uma vez que nele a visão de mundo é explicitada sem medo de não ser "politicamente correta"; nele, o profano não se constrange em conviver com o sagrado, a dicotomia bem e mal é sempre explicitada sem culpa, o permitido e o proibido são vivenciados sem questionamentos pelas tradições e o que pode ser sacralizado também pode ser profanado; a alma e o espiritual convivem sem medo de não serem compreendidos e interagem com o corpo e o material num grande diálogo.

Nas comunidades populares, as tradições e os modos viventes são sempre vivenciados na coletividade. Portanto, mesmo quando as manifestações das culturas populares subalternas são deslocadas de regiões, ou do rural para o urbano, esses conhecimentos tradicionais são adaptados e passados para a nova comunidade sem grandes questionamentos; são ressignificados; são aceitos ou sofrem adaptações sem perder sua essência, pois, as comunidades populares não ficam questionando a validade ou pertinência das adaptações necessárias; fazem-nas e continuam com seus viveres. Continuam com seus avatares, incorporados e travestidos para atender suas necessidades imediatas. Preservando deste modo sua essência.

Quem nunca ouviu ou viu uma "senhorinha" na porta de um grande supermercado, no ponto de ônibus ou no elevador do prédio se 
intrometer na conversa do outro e indicar uma oração infalível, um chá, uma simpatia, para acalmar o bebê que não dorme, ou para uma dor no pé? Assim, as festas das Folias de Reis também chegaram às grandes cidades ou às periferias das cidades, em decorrência do êxodo rural, fazendo o giro no ônibus de bóia-fria, ou no transporte escolar, alterando o dia da festa; mas chegaram e foram se incorporando ao bairro novo, adaptando a tradição, mesmo quando o bairro é um Conjunto Habitacional (COHAB), com suas ruas padronizadas e casas idênticas, que logo adquirem a cara de seu morador, pela presença da imagem da Virgem Maria pregada na porta, ou de uma plaquinha escrito "Deus é Fiel", ao lado da bandeira do time do coração; as benzedeiras se estabelecendo independentemente do Pastor, do Vigário, do posto do SUS estarem no mesmo bairro. Assim, também as Folias foram chegando e se estabelecendo e a crença em Santos Reis, mantida: "ô de casa, ô de fora, Santos Reis está chegando, pedindo pra entrar e abençoar sua família, a bandeira quer entrar e acolher o seu pedido".

Daí a necessidade de, neste trabalho, dar voz aos foliões e aos artistas que retratam e registram as festas. Mesmo, como já mencionado na introdução, com longas citações no corpo do texto. Não seria coerente remetêlas para os anexos; essa prática já está bem difundida na academia. Foi necessário, também, um capítulo muito descritivo para abarcar toda sua complexa estrutura, a fim de sustentar as indagações propostas.

As culturas populares podem, sim, ser documentadas e reescritas pelos artistas oriundos de suas comunidades. Os artistas populares e suas diferentes linguagens, entendidas como documentos, podem, sim, ser lidos a partir do momento que os elementos constitutivos de suas linguagens 
são conhecidos e interpretados. E, principalmente, as tradições são explicitadas e perpetuadas pelas representações iconográficas, principalmente as Folias de Reis. Não existe Folia de Reis sem bandeira: ela é o Grande Avatar, a encarnação viva dos Reis que percorrem os bairros e casas, criando outro avatar, o giro das folias, quando sacraliza os espaços e faz deles um duplo, uma outra dimensão onde o sagrado caminha.

E, portando, as Festas estudadas explicitaram sua característica: a de produzir uma constante evolução e adaptação no tempo e no espaço. E sustentam a produção, a troca, a circulação dos bens materiais e imateriais de uma comunidade em diferentes momentos da história, bem como na atualidade. Gerando bens culturais que são apropriados e utilizados pelos diferentes meios de comunicação atuantes.

As festas exigiram o uso de diferentes ciências para compreendê-las e seu estudo produziu um texto interdisciplinar, em que diferentes problematizações tiveram que dialogar; também foi importante ancorar as propostas apresentadas preferencialmente em pesquisadores que pensam a cultura no e do Brasil, bem como a latinidade e o subalterno. Deste modo, foi possível apresentar a proposta de que as manifestações imagéticas e iconográficas podem sustentar a permanência das festas populares, principalmente nas Folias de Reis, e estas manifestações iconográficas podem ser depositárias do ethos das festas populares, propiciando uma outra via de compreensão das culturas subalternas, ainda pouco explorada nas Ciências Sociais: os registros visuais do povo como documento das culturas populares subalternas. 
Também foi demonstrado que a festa é um acontecimento coletivo composto de um conjunto formal de procedimentos e atitudes que refletem as formas de pensar e agir de uma comunidade, ocasionando uma configuração de semelhanças e diferenças marcantes.

Foi igualmente possível demonstrar que:

a) as Folias de Reis mantêm em seu núcleo atitudes e elementos imutáveis - elementos avatárticos - que podem ser detectados em diferentes épocas e lugares, e que esses elementos iconográficos avatárticos auxiliam no entendimento e perpetuação das práticas ritualísticas e simbólicas aglutinadoras dos grupos geradores das culturas populares subalternas; e

b) é necessário ampliar as reflexões sobre as inúmeras conceituações empregadas para compreender e classificar os artistas populares e suas produções como expressão artística brasileira.

O trabalho apresentado indica, ainda, que uma região formada no surgimento das bases do que se chamou modernidade pode abrigar um objeto de estudo para se compreender o sentido de brasilidade - mesmo quando os processos modernizadores apresentam-se como mais fortes - e, principalmente, que esses processos não são suficientemente fortes para descaracterizar o ethos do que poder-se-ia chamar, neologisticamente, brasíndio, brasiafro, brasimestiço ou brasilíbrido, enfim, nosso ethos popular nacional.

No trabalho exposto, é possível perceber ainda que: o sentido de brasilidade se dá pelo povo, pelo popular, pelo subalterno, de dentro para fora, do interior do ser e da espacialidade para o exterior, para a cidade, para a 
metrópole - tão descaracterizada pelo global, pelo massivo e universal midiatizado.

O subalterno está no ser (no avatar), está na/no (festa, objetos), está em (uma comunidade, espacialidade), está com (o contemporâneo), apesar de ser visto como um apêndice cultural.

As manifestações do popular e do subalterno, urbano ou rural, abrigam tradições ainda pouco visitadas pela academia e pelas ciências; mas abrigam a identidade, o cerne da brasilidade, para que a academia compreenda o sentido da formação da cultura brasileira. Assim como apontam para uma capacidade de comunicação pouco notada, mas estruturada e portadora de uma metodologia que pode nortear pesquisas e avanços para a compreensão da atualidade.

Na era do império do visual -tão antigo como o próprio homem que, desde seus primeiros processos comunicativos usou a imagem e as representações visuais para transpor o tempo, relacionar-se com 0 incognoscível e com o cognoscível-, o que se propõe é que, nesse império do visual, as manifestações populares imagéticas possam ser vistas como um processo comunicativo e que, ao entendê-las como veículo comunicacional, seus elementos possam ser compreendidos e que esta compreensão contribua para ampliar o entendimento das culturas populares subalternas. 


\section{REFERÊNCIAS BIBLIOGRÁFICAS}

ALVES, Paulo. Ourinhos: uma perspectiva histórica (1905-1994). Material elaborado pelo Departamento de História da Unesp de Assis, 1990.

AMARAL, Aracy. Tarsila, sua obra seu tempo, vol. I. São Paulo: Perspectiva, 1975.

ARDIES, Jacques. A arte naif no Brasil. São Paulo: Galeria Jacques Ardies, 1998.

ARENDT, Hannah. Entre o passado e o futuro. 5ed. São Paulo: Ed. Perspectiva, 2005.

ARGOLLO, André. Arquitetura do café. Campinas: Unicamp, 2004.

As Estradas de Ferro do Estado de São Paulo. Disponível em: $<w w w$.brasilferrovias.com.br>, <www.estacoesferroviarias.com.br>. Acesso em: 2 de agosto de 2007.

ASSIS. Machado. A parasita azul. Disponível em:

<http://www.dominiopublico.gov.br/download/texto/bv000186.pdf>. Acesso em: 26 de outubro de 2008.

AVANCINI, José Augusto. Arte e Cultura da América Latina. Ano II, $n^{\circ} 3-$ Setembro, 1992. São Paulo: Sociedade Científica de Estudos da Arte - CESA.

AYALA, Walmir. O museu dos primitivos de Assis. Jornal do Comércio. Rio de Janeiro, 6-7 Fev. 1983, Leilão: Artes Plásticas. Documento do arquivo CEDAP

BARBOSA, Ana Mae. A imagem no ensino da arte. São Paulo:

Perspectiva, 1991.

BARDI, Pietro Maria. Os heróicos museus do Interior: Esperanças para uma atividade maldita. Senhor. Assis: Chateaubriand; Museu de Arte de São Paulo, v. 11,1983. Documento do arquivo CEDAP.

BASTIDE, Roger. As religiões africanas no Brasil. São Paulo, Pioneira, 1985 [1960].

BATISTA. Raimunda B.; DOMICIANO, Regina M. G. (Orgs.); HADDAD, Rosangela R.; UEDA, Ruth H. S. Catálogo da Correspondência Ativa de George Craig Smith. Disponível em:

<http://www.uel.br/museu/complementares/colonizacao.html>. Acesso em: 10 de agosto de 2007. 
BERLO, David K. O processo da comunicação. São Paulo: Ed. Martins Fontes, 1991.

BÍBLIA Sagrada. 149a. ed. São Paulo: Editora Ave Maria, 2002.

BIROU, Alain. Dicionário das Ciências Sociais. 2.ed. Lisboa: Dom Quixote, 1966.

BOFF, Leonardo. A águia e a galinha: uma metáfora da condição humana. 27.ed. Petrópolis, RJ: Vozes, 1997.

BOSCARIOL, Renan Amabile. Formação sócio espacial e urbana na cidade de Ourinhos/ SP. Disponível em:

<http://www.ourinhos.unesp.br/gedri/publica/gedri/2048.pdf>. Acesso em: 17 de agosto de 2007.

BOSI, Alfredo. Dialética da colonização. São Paulo: Companhia das Letras, 1992.

Reflexões sobre a arte. São Paulo: Ática, 1989.

BOSI, Eclea. Memória e Sociedade: lembranças de velhos. 3.ed. São Paulo: companhia das Letras, 1994.

BRANDÃO, Carlos R. A memória do sagrado: Estudos de religião e ritual. São Paulo: Edições Paulinas, 1985.

BRUÑEL, Pierre (org). Dicionário de mitos literários. Trad. Carlos Sussekind et al. 2.ed. Rio de Janeiro: José Olympio, 1998.

BURKE, Peter. Hibridismo Cultural. RS: Unisinos, 2003.

CAES, André Luiz. A Devoção a Sathya Sai Baba e a Integração de Aspectos do Hinduísmo ao Universo Religioso Brasileiro e Ocidental. Revista Eletrônica Rever - ISSN 1677-1222. n.4, ano 6, 2006. SP: PUC.

CALVINO, Ítalo. A palavra escrita e a não-escrita. in: FERREIRA, Marieta de Moraes; FIGUEIREDO, Janaina P. Usos \& Abusos da História Oral. 6.ed. Rio de Janeiro: FGV, 2005.

CANCLINI, Nestor G. As culturas populares no capitalismo. São Paulo: Brasiliense, 1983.

CASCUDO, Luis da Câmara. Dicionário do Folclore Brasileiro. 10.ed. São Paulo: Global, 2001. 
CELESTINO, Antonio. Cardoso e Silva: Gente da Terra. São Paulo: Martins Fonte, 1972.

CHEVALIER, Jean; GHEERBRANT, Alain. Dicionário de símbolos. 11.ed. Rio de Janeiro: José Olympio, 1997.

CHRISTO, S.L. Maria. Fogão de lenha: Quitandas e quitutes de Minas Gerais. São Paulo: Editora Vozes, 1977.

COÊLHO, Plínio Salgado (Org e Trad.). Goya: os desastres da guerra. São Paulo: Imaginário, 2003.

COMISSÃO Pró Índio de São Paulo. Índios no Estado de São Paulo. Disponível em <http://www.cpisp.org.br/indios/index_all.html>. Acesso em: 9 de agosto de 2007.

COSTA, Soledade M.; BARROS, Jorge. Festas e Tradições Portuguesas: Ritos, Memória e Identidade. Portugal: Editora Círculo de Leitores, 2002.

CUNHA, D. C.Tereza. Memórias de São Pedro do Turvo. São Pedro do Turvo: Prefeitura Municipal de São Pedro do Turvo, 1996.

D' AMBRÓSIO, Oscar (Org.). Conto, canto e encanto com minha história: Ourinhos um século de história. São Paulo: Nhoova América, 2004.

DANTAS, Arruda. Memória do Patrimônio de Assis. 2.ed. São Paulo: Pannartz, 1980.

DEL RIOS, Jefferson. Ourinhos: memórias de uma cidade paulista. São Paulo: IMESP, 1992.

ELIADE, Mircea. O conhecimento sagrado de todas as eras. São Paulo: Mercuryo, 1995.

Fontes, 1992.

O sagrado e o profano. Trad. Rogério Fernandes. São Paulo: Martins

FERREIRA, Maria Nazareth (Org.). A tradição e seu significado para o turismo cultural: o Vale do Paraíba. São Paulo: CELACC- ECA/USP, 1999.

(colab.) Globalização e Identidade Cultural na América Latina. Centro Brasileiro de Estudos Latino Americanos - CEBELA: São Paulo, 1995.

(org.). Comunicação, resistência e cidadania: as festas populares. Comunicação\&política, v.24, n². Rio de Janeiro: Centro Brasileiro de Estudos Latino-Americanos - Cebela, 2006. 
(Org.). Cultura subalterna e neoliberalismo: a encruzilhada da América Latina. São Paulo: CELACC- ECA/USP, 1997.

(org.). Identidade cultural e turismo emancipador: a experiência italiana. São Paulo: CELACC- ECA/USP, 2005.

Alternativas Metodológicas para a produção científica. São Paulo: CELACC - ECA/ USP, 2006.

Os antigos rituais agrários itálicos e suas manifestações na atualidade. Comunicação e Política. São Paulo: CEBELA, v. $7, n^{\circ} 1$, nova série, jan-abr, 2000.

FREIRE, Gilberto. Sobrados e Mucambos. 14.ed.São Paulo:Global, 2003.

GARBOSI, Francisco. História, mensagens e embaixadas de Folia de Reis. Londrina: Francisco Garbosi, 2002.

GENEROSO, Geraldo P. Forças Vivas de Ipaussu - I.Ipaussu: Prefeitura Municipal de Ipaussu, 2006.

GONÇALVES, Maria Célia S. Folia de Reis: O eco da memória na reconstrução da performance e identidade dos foliões em João Pinheiro, estado de Minas Gerais. IV ENECULT - Encontro de Estudos Multidisciplinares em Cultura. Faculdade de Comunicação/UFBa, 2008. Disponível em:< http://www.cult.ufba.br/enecult2008/14437-04.pdf>. Acesso em: 23 de junho de 2008.

GRAMSCI, Antonio. Cadernos do Cárcere. Vol. 1 a 6. Trad. COUTINHO, Carlos N. Rio de Janeiro: Civilização Brasileira, 2002. Coleção em 6 volumes.

HAUSER, Arnold. Teorias da Arte. 2.ed. Lisboa: Editora Presença, 1998.

HELLER, Agnes. O cotidiano e a história. 2.ed. Rio de Janeiro: Ed. Paz e Terra, 1985 ,

HOBSBAWN, Eric e RANGER, T. (orgs.). A invenção das tradições. Tradução de Celina Cardim Cavalcante. Rio e Janeiro, Paz e Terra, 1984.

ISA - Instituto Socioambiental. Povos Indígenas no Brasil. Disponível em: <http://www.socioambiental.org/pt/index_html >. Acesso em: 10 de agosto de 2007.

ITANI, Alice. Festas e calendários. São Paulo: Unes, 2003.

JEUDY, Pierri H. Memórias do social. Tradução de Márcia Cavalcanti. Rio de Janeiro: Forense Universitária, 1990.( Ensaio e Teoria) 
JOLY, Martine. Introdução á Análise da Imagem. $2^{a}$ ed. São Paulo: Papirus Editora. 1999

JUNG, Carl G. O homem e seus símbolos. Tradução Maria Lúcia Pinho. Rio de Janeiro: Nova Fronteira, 1964.

JUNQUEIRA, José M. Santa Cruz do Rio Pardo: memórias. Santa Cruz do Rio Pardo, 1994. Editado pelo autor.

JURKEVICS, Vera I. Festas religiosas: A Materialidade da Fé. História: Questões \& Debates. Curitiba, n. 43, p. 73-86, 2005. Editora UFPR. Disponível em: $<$ http://ojs.c3sl.ufpr.br/ojs2/index.php/historia/article/viewFile/7863/5547>. Acesso em: 15 de maio de 2007.

KANTOR, Íris (Org.) et al. Festas e Sociedades na América Portuguesa. v.2.São Paulo: Hucitec, 2001.

LEITE, Serafim. Os jesuítas na Vila de São Paulo. Antologia. São Paulo: Departamento do Patrimônio Histórico, v.202, p.29-61, 2004.

MADRÍZ, Maria Fernanda. La Cultura Popular en Gramsci, Caracas, Anuário ININCO, n² 2, 1989, UCV.

MAGNANI, José Guilherme Cantor. Festa no pedaço: cultura popular e laser na cidade. 3.ed. São Paulo: Hucitec, 2003.

MAISTRO, Vitório P. Memórias de Ipaussu. Ipaussu: Câmara Municipal de Ipaussu, 1995.

MANGUEL, Alberto. Lendo imagens: uma história de amor e ódio. São Paulo: Cia das Letras, 2001.

MAPA das estradas de ferro do Estado de São Paulo. Disponível em: <pt.wikipedia.orgwikiFerrovia_Paulista1987_SA>. Acesso em: 17 de agosto de 2007.

MARCONDES FILHO, Ciro. Até que ponto, de fato, nos comunicamos?: uma reflexão sobre o processo de individuação e formação. São Paulo: Paulus, 2004.

MARTINS, José de Souza. Capitalismo e Tradicionalismo. São Paulo: Pioneira, 1978.

MASSEI, Roberto. As inovações tecnológicas e o acaso dos oleiros: A mecanização das olarias em Ourinhos: 1950-1990. 175f. Dissertação de Mestrado em História Social, Pontifícia Universidade Católica, São Paulo, 2001. 
MASSIMI, Mariana; GUEDES, Maria C. História da Psicologia no Brasil: Novos estudos. São Paulo: Cortez Editora, 2004.

MIMESSI, José Nazareno. Pintura Primitiva (Naïve) - Resultados de uma pesquisa. Assis, 1991.

MONTES, Maria Lúcia A. Entre O Arcaico e o Pós-Moderno, Uma Cultura da Festa. Revista Sexta-Feira, São Paulo, v.2, 1998. Disponível em:

$<$ http://www.antropologia.com.br/tribo/sextafeira/pdf/num2/entre_o_arcaico.pdf>Ac esso em: 15 de maio de 2008.

MORAES FILHO, Mello. Festas e tradições populares no Brasil. Belo Horizonte: Ed. Itatiaia; São Paulo: Ed. da Universidade de São Paulo, 1979.

MORAES, Denis de (org). Por uma outra comunicação: mídia, mundialização cultural e poder. 2. ed. Rio de Janeiro: Record, 2004.

MOREIRA, Maria de Fátima S. A organização do processo de trabalho: sua dimensão política na estrada de ferro Sorocabana (1920-1940). 1989. 300f. Dissertação (Mestrado em História) - Faculdade de Ciências e Letras, Universidade Estadual Paulista, Assis, 1989.

MOTA, C.F. Lucio Tadeu. Os índios Kaingang e seus territórios nos campos do Brasil meridional na metade do século passado. In: UriWãxi: estudos interdisciplinares dos Kaingang. Londrina, Eduel, 2000.

MUSEU DE PINTURA PRIMITIVA DE ASSIS (Assis, SP). Catálogo comemorativo do $2^{\circ}$ Aniversário do Museu de Pintura Primitiva de Assis: catálogo. Assis, 1985. Catálogo $n^{\circ} 4$.

NOVAIS, Fernando A. (Coord.). Contraste da intimidade contemporâneo. São Paulo: Companhia das Letras, 1998 (História da Vida Privada - 4).

(Coord.). Cotidiano e vida privada no Brasil. São Paulo: Companhia das Letras, 1997 (História da Vida Privada - 1).

(Coord.). Império - a corte e a modernidade nacional. São Paulo: Companhia das Letras, 1997 (História da Vida Privada - 2).

(Coord.). República - da Belle Époque à era do rádio. São Paulo: Companhia das Letras, 1998 (História da Vida Privada - 3).

ORTIZ, Renato. Cultura Popular: Românticos e Folcloristas. São Paulo: Olho D’água, 1985.

PENÇO, D. C. F. Célia. A evaporização das terras devolutas no Vale do Paranapanema. Tese de doutorado em Geografia - Instituto de Geografia Humana, Universidade de São Paulo, São Paulo, 1981. 
PEREZ, Léa F. Breves notas sobre a religiosidade brasileira. Brasil 500 anos, Belo Horizonte, p. 40-58, 01 jun. 2000. Disponível em:< http://www.antropologia.com.br/arti/colab/a8-Ifreitas.pdf >. Acesso em: 20 de junho de 2008.

Dionísio nos trópicos: festa religiosa e barroquização do mundo. Espaço virtual da internet: comunidade virtual de antropologia, 2003 (Textos publicados). Disponível em:< http://www.antropologia.com.br/arti/colab/a12-Ifreitas.pdf >. Acesso em: 20 de junho de 2008.

PINHO, Diva B. A Arte como Investimento. A dimensão econômica da pintura. São Paulo: Nobel/EDUSP, 1988.

PRADO JÚNIOR, Caio. Formação do Brasil contemporâneo. São Paulo: Publifolha, 2000.

PREFEITURA Municipal de Ourinhos. Disponível em: <www.ourinhos.sp.gov.br> Acesso em: 12 de janeiro de 2006.

RAMOS, Duílio. História da Civilização Brasileira. 6.ed. São Paulo: Saraiva, 1969.

RIBEIRO, Darcy. O povo brasileiro - a formação e o sentido do Brasil. 2.ed. São Paulo: Companhia das Letras, 2003.

RIOS, R. José. Coronel Tinoco Lista - o perfil de uma época. Santa Cruz do Rio Pardo: Debate, 2004.

RIOS, Sebastião. Os cantos da festa do reinado de Nossa Senhora do Rosário e da Folia de Reis. Sociedade e Cultura, vol.9, n.1, jan/jun. 2006, p.65-76.

Disponível em: <http://revistas.ufg.br/index.php/fchf/article/view/215/185>. Acesso em: 20 de julho de 2008.

ROMERO, Fernanda S.; MORAES, Rosemary R. Um espaço para lembranças de Ourinhos. Ourinhos: Prefeitura Municipal de Ourinhos, 2004.

SAES, Flávio A.M. As ferrovias de São Paulo 1870-1940: Expansão e declínio do transporte ferroviário em São Paulo. São Paulo: HUCITEC, 1981.

SALIBA, Elias T. As Utopias Românticas. São Paulo: Estação Liberdade, 2003.

SANTAELLA, Lúcia. Culturas e Artes do Pós-Humano: cultura das mídias à ciber-cultura. São Paulo: Paulus, 2004.

SANTOS, Milton. Por uma Geografia Nova, Rio de Janeiro: 1974, p.174. 
SCHECHNER, Richard. O que é performance. 2002. Disponível em:

$<$ http://hemi.nyu.edu/course-

rio/perfconq04/materials/text/OqueePerformance_Schechner.htm>. Acesso em: 22

- Dez - 2008.

SILVA, Dilma M. Arte e Cultura da América Latina. Ano II, nº 2 - Julho, 1991.

São Paulo: Sociedade Científica de Estudos da Arte - CESA.

SILVA, Francis P. L. Misticismo popular na poética mineira. In: V Congresso de Letras - Discurso e Identidade Cultural, 2005, Caratinga. V Congresso de Letras Discurso e Identidade Cultural - CD Rom. Caratinga: UNEC, 2005. v.1. Disponível em:

<http://bibliotecadigital.unec.edu.br/ojs/index.php/unec02/article/viewFile/248/326>. Acesso em: 15 de março de 2007.

SILVA, Rubens Alves da. Entre "artes" e "ciências": a noção de performance e drama no campo das ciências socias. Horiz. antropol.,- Porto Alegre,- v. 11,- n. 24, Dec.- 2005 .- Disponível em:

$<$ http://www.scielo.br/scielo.php?script=sci_arttext\&pid=S0104-

$71832005000200003 \&$ Ing=en\&nrm=iso>. Acesso em: 22 de dezembro de 2008. doi: 10.1590/S0104-71832005000200003.

SILVEIRA, Ênio (Org.). Encontros com a civilização brasileira. RIBEIRO, Darcy. Sobre o óbvio. Rio de Janeiro: Civilização Brasileira, v.1, p.9-23, 1978.

SOUZA, Jessé. Gilberto Freire e a singularidade cultural brasileira. Tempo Social. V.12, n¹, maio, p 69-101, 2000.

THOMPSON, Edward P. Costumes em comum: estudos sobre a cultura popular tradicional. São Paulo: Companhia das Letras, 1998.

TINHORÃO, José R. As festas no Brasil colonial. São Paulo: Editora 34, 2000.

TURNER, Victor W. The Anthropology of Performance. New York: PAJ

Publications, 1988.

VANNUCHI, Aldo. Cultura Brasileira: o que é, como se faz. 3.ed. São Paulo: Loyola, 1999.

VICENTE, Gil. Obras de Gil Vicente. Portugal, Porto: Lello \& Irmão Editores, 1965.

ZANONI, M.J.C.O. Santa Cruz do Rio Pardo: nossa terra, nossa gente. Bauru, SP: Ed. Osmare, 1976. 
ANEXO A - Transcrição das cantorias da Cia. dos Faceiros, Palmital/SP

Canto -1

Santos dos Reis, ai, ai

Santos Reis vai dar saúde, ai, ai

Pra cantar o resto do dia, ai, ai

Pra cantar o resto do dia, eh...

Em nome de Santos Reis, ai, ai

Agradece a companhia, ai, ai

Agradece a companhia, eh...

Santos Reis Ihe pede oferta, ai, ai

Quantia que possa dar, ai, ai

Quantia que possa dar, eh...

Coração que vai mandar, ai, ai

Coração que vai mandar, ai, ai, eh...

Canto - 2

Santos Reis, ai, ai

Agradece a boa oferta, ai, ai

Ofertada em alimento, ai, ai

Ofertada em alimento, eh...

A mensagem que nos deu

De hoje vir no sacramento, ai, ai

De hoje vir no sacramento, eh...

Segurando essa bandeira, ai, ai

De apoio e agradecimento, ai, ai

De apoio e agradecimento, eh...

Canto - 3

Isso vem de geração, ai, ai

Isso vem de geração, eh...

Isso nunca vai acabar, ai, ai

A bonita religião, ai, ai

A bonita religião, eh...

Agradece a boa oferta, ai, ai

Nessa hora de alegria, ai, ai

Nessa hora de alegria, ai, ai, eh...

Vou pedir pra Santos Reis

Abençoar sua família, ai, ai

Abençoar sua família, ai, ai, eh...

Essa bença vem do céu

De Jesus, Santa Maria

De Jesus Santa Maria, ai, ai, eh...

Santos Reis te abençoa ai

$\mathrm{Na}$ hora da cantoria

Na hora da cantoria, ai, ai, eh...

Canto - 4

Dia primeiro de janeiro do ano 2006
Eu recebi um convite pra cantar pra

Santos Reis

$\mathrm{Na}$ cidade de Palmital

Um povo muito cortês

Peguei a minha viola

E não cantei duas vez

Terceiro Anjo da mente

Este convite me fez

$\mathrm{Na}$ hora que eu fui chegando

Momento de alegria

Cumprimentei os amigos

Rojão pro arto sendia

Os foliões reunidos

Numa linda cantoria

Batia, caixa, e pandeiro

Violão e viola que mia

E a bandeira dos Treis Reis

Sua flor resplandecia

Até o Faceiro cantava

Fazendo nova embaixada

O Zé Gordo ajudava com sua viola

Com sua viola afinada

O Circinho no contrato

Puxando a companheirada

O Rubinho e o Robson

A sete voz completava

$A$ bandeira viajou

Durante os doze dias

Visitou sítio e fazenda

Muita prenda recebia

Pra cumprir uma promessa

De uma graça alcançada

De um grande mal que sofria

Louvamos Jesus Menino

Filho da Virgem Maria

Hoje a bandeira vai se embora, ai, ai

Pra voltar o ano que vem, ai, ai

Pra voltar o ano que vem

Canto - 5

Santo dos Reis

Pai trazei um ano bom, ai, ai, eh...

E também muita saúde, ai, ai

Toda sua geração

$E$ também muita saúde

Mais toda sua geração, ai, ai, eh...

Esperamos por notícia

Mas seu bondoso coração, ai, ai, eh...

Nóis esperamos por notícia 
Mas seu bondoso coração, ai, ai, eh...

Levando a esperança

Para manter a tradição

Pra manter a tradição, ai, ai, eh...

Com a fé em Jesus Cristo ai,ai

$\mathrm{E}$ amigo dos folião

Com a fé em Jesus Cristo

E amigo dos folião, ai, ai, eh...

No dia 6 de janeiro, ai, ai

Encontramo cidadão

No dia 6 de janeiro

Encontramo cidadão, ai, ai, eh...

Encontramo sorridente

Muita salva de rojão

Encontramo sorridente ai

Muita salva de rojão, eh...

Como vai sua família?

E a sua geração?

Como vai sua família?

E a sua geração, ai, ai, eh...

Boa tarde minha senhora

Tão feliz tão todos bão?

Boa tarde minha senhora

Tão feliz tão todos bão? ai, ai, eh...

Eu vou fazer um pedido

Mas não vai dizer que não

Eu vou fazer um pedido

Mas vóis não vai dizer que não, ai, ai, eh...

Leva a bandeira na frente

Da chegada ao folião

Leva a bandeira na frente

Ai da chegada ao folião, eh....

Então vamos caminhando

Acompanhando o cidadão

Caminhando, caminhando

Acompanhando o cidadão, ai, ai, eh...

No final que foi encontrada

Nosso pai da salvação

No final que foi encontrada

Pai nossa da salvação, ai, ai, eh...

Abençoai o cidadão

Abençoai o cidadão, ai, ai, eh...

Ele tá muito orgulhoso

Ele ta muito orgulhoso, ai, ai, eh...

Caminhando, caminhando

Acompanhando o cidadão

Caminhando, caminhando

Acompanhando o cidadão, ai, ai, eh...

Os Três Reis do oriente
Sorria de alegria

Os Três Reis do oriente

Sorria de alegria, ai, ai, eh...

Encontrou o Menino...

Filho da Virgem Maria

Encontrou o Menino

Filho da Virgem Maria, ai, ai, eh...

Eu vou fazer um pedido

Mas não vai arreparar

Eu vou fazer um pedido

Mas vóis não vai arreparar, ai, ai, eh...

Por favor acende a vela

Por favor acende a vela

Os Três Reis do Oriente

Viajando sem parar

Os Três Reis do Oriente

Viajando sem parar, ai, ai, eh...

Procurando o Menino

Foram todos encontrar

Procurando o Menino

Foram todos encontrar, ai, ai, eh...

$O$ verdadeiro Menino

O Anjo na Galiléia

$O$ verdadeiro Menino

O Anjo na Galiléia, ai, ai, eh...

Canto - 7

Agradecemos a Deus pela graça do Carpinteiro

Que quando foi iluminado da graça recebeu

Naquela cidade que ali também

existia

Uma Virgem abençoada com o

nome de Maria

No tempo de Jerusalém se ajuntaram em casamento

Recebeu o matrimonio do Divino sacramento

Vivendo tão inocente por muitos anos passaram

Até que a paixão bendita Deus a eles realizaram

Aquela Virgem inocente

Deus a Ela contemplou

Desceu o Anjo do

Céu e para a Virgem assim falou ....

Maria, Deus me mandou e contigo vim falar

Se tu queres receber o Divino Rei celestial

Maria muito assustada vendo o que o Anjo falava 
Se me acha suficiente

Eis aqui a sua Escrava

De joelho com a mão posta

De joelho a Deus Ela implorava

Entraram até minha vida

Para cumprir sua palavra

Que é mandado por Deus e em

sua presença estou

Desceu o Espírito Santo

E o Rei ai escarnou

25 de Março Maria concedeu

No ventre da Virgem Santa

Nove meses se escondeu

Maria estava esperando

Quando o Rei mandar chamar

Para irecenciar os Árabes

Todos no geral

Esse Rei era da Síria e

A Síria governava

Para ir se alistar

Todo mundo ele obrigava

Sair de Jerusalém

Virgem Maria e José

Para dar seu nome rude na

matriz de Israel

Chegando nessa cidade

Não encontraram hospedagem

Então ficaram contemplados

De tão cansado da viagem

Os hotéis tavam lotados

Não havia mais lugar

Sairão então procurando

Um jeito de se agasalhar

Ali perto da cidade onde as

ovelha pastavam

Os pastor do rebanho ali por perto estavam

Aquela Virgem amorosa o pastor perguntava

Onde está sua casinha que eles

descansava

O pastor disse para a Virgem

Daqui a senhora vê

Mas a choupana e pequena

É capaz de não caber

A Virgem olhou para o pastor

com um sorriso de alegria

Para dar exemplo ao mundo

Que qualquer lugar lhe servia

Isso que já era de tarde

A noite escura já vinha

Mas ainda chegou em tempo de limpar sua casinha

Maria lá do lado a Seu José ela dizia
Se encostasse num cantinho

Deitasse ele dormia

25 de dezembro foi um dia de

alegria

E nasceram o Rei do mundo

Filho da Virgem Maria

No ponto da meia-noite

Hora que o galo cantou

Jesus menino era nascido

Quando Seu José acordou

Desceram milhares de Anjo

$\mathrm{Na}$ hora do nascimento

Mandado pelo Pai Eterno

Do Divino Sacramento

Até os animais fizeram

entendimento

Adorar Jesus na hora do nascimento

O Menino para ele dar o seu calor

Até os brutos sabiam que Ele era o

Salvador

$\mathrm{Na}$ hora que Jesus nasceu apareceu

no firmamento

Uma Estrela no oriente

Anunciando o seu nascimento

Na Média, na África e na Arábia

Viam os Reis religiosos

Acreditavam que haveria

O Príncipe Rei poderoso

Eles estavam dormindo

Tiveram um sono profundo

Que na terra já havia

O suplente Rei do mundo

Eles se levantaram

Tiveram uma só idéia

Pegaram seus camelos

E viajaram para Galiléia

Saíram de seus países

Cada um saiu sozinho

Depois de viajarem muito

Se encontraram no caminho

Eles eram astrólogo

Tudo os astros eles sabiam

Por isso foram avisados

A hora que Jesus nascia

A viagem dos Três Reis

Pela estrada foi guiada

Vou falar agora do encontro na

estrada

O Gaspar saiu sozinho nessa longa

caminhada

Foi encontrar o Baltazar

Na segunda encruzilhada

Os dois Reis se encontraram

Essas palavras faladas

Vamos encontraram o Belchior 
$\mathrm{Na}$ terceira encruzilhada

Os Três Reis se encontraram

Perante a Estrela guia

Vamo visitar Jesus, José e Maria

Vamo!

Quando chegaram em Herodes

A Estrela desapareceu

Por qual motivo era os Três Reis

não percebeu

Foram perguntar a Herodes se por acaso ele sabia

Onde tava o Rei do mundo

Que o Eterno Pai prometia

Vai vim uma só estrela com seu raio anunciar

Sendo essa cidade santa viemos aqui procurar

Com as palavras dos magos

Herodes se indignou

Dizendo para os Três Reis

O mundo eu quem sou

Herodes chamou o povo da corte

Um sábio adivinhador

Se acaso ele sabia onde tava o redentor

Veio da corte um sábio com a sua teoria

Foi em Belém de Judá

Assim o profeta dizia

Herodes disse aos Três Reis

Irem em Belém procurar

Se encontrarem o Menino

Voltem aqui para me avisar

Informe bem do Menino

E me traga informação

Eu também quero adorar esse

Rei da Salvação

Os Três Reis não sabiam da sua má intenção

Saíram todos contentes

Cheios de satisfação

Saíram de Herodes a Estrela despontou

No peito da Virgem Santa muito raio de luz brilhou

Desceram serra abaixo quando

em Belém chegaram

Foram parando seus camelos

De todos os três arriaram

Os Três Reis se admiraram por ver tanta pobreza

Não sabendo que Ele era o dono de toda riqueza

A choupana era pequena

Que nem os Reis cabia
Para dar os seus presentes

Que pro Menino trazia

Ele não tinha agasalho

De nada disso Ele tinha

E o frio era tanto

Que o coitadinho até tremia

O boi bento abafejava vinha a mula

e descobria

Ela foi amaldiçoada por sua má intenção

Sendo filha das égua

Não aumentando a produção

Foi os Três Reis de joelho para

fazer as oração

Beijaram o pé do Menino e pediram

a santa benção

Na presença de Jesus os Três Reis

do oriente

Foram abrindo os seus cofres

$E$ ofertando seus presentes

O presente que levavam era coisa

de valor

Ouro, incenso e mirra que ofertaram

a seu senhor

Ouro por ele ser Rei

Ora a Ele pertencia

Incenso por seu humano

E mirra porque morria

Os Três Reis vindo de volta

Por um sonho o Anjo avisou

Que não passasse em Heródes

Que ele era uma traidor

Os Três Reis se levaram

Chorando se despedia

A emoção era tanta que choraram de alegria

Despediram de Jesus, São José e de Maria

Mas pra passar em Herodes não sabia como fazia

O Anjo saiu na frente fazendo uma

meia lua

Enganando o Rei Herodes

Passaram por outras duas

Herodes viu-se enganado

Muito mais se indignou

Soltou a cavalaria e a espada

entregou

Toda mãe que for Maria

Vocês saem para informar

$\mathrm{E}$ os meninos até dois anos

São obrigado a matar

As pobres mães que choravam

Mas os juDeus não temiam

Chegavam nos seus berçinhos 
Os meninos até sorriam

Pegavam pelo braçinho

E para cima suspendiam

A espada atravessavam

Nem viam do que morriam

O Anjo São Gabriel a José ele dizia

Ocês fogem pro Egito

Que Herodes perseguia

Pra matar o menino Deus

$E$ era isso que ele queria

José pegou o Menino

Com Maria fugia

Mas a longa viagem

De encontro à tropa já vinha

Maria virou uma árvore

Que ali não respondia

A árvore cobriu de flores

O judeu não percebia

Depois que a tropa passou

De novo a Virgem seguia

Logo adiante no pé da Serra

De novo a tropa já vinha

O Anjo virou uma pedra

Que a ele respondia

Chegaram lá no Egito

Ficaram livres do Judeus

E lá ficaram morando até que

Herodes morreu

Um dia bem de tardinha

O Anjo veio avisar

Pode voltar para Belém

A sua terra natal

Viva o Menino Deus

E a Companhia dos Três Reis

Viva!

Muito obrigado Rubinho

Que bonita a saudação

Muito obrigado Rubinho

Mas que bonita a saudação, eh...

Deus que lhe abençoa

E lhe dê tanta benção

Outro Rei te dê benção

Vem aqui o meu palhaço

Fazes tua obrigação

Vem aqui meu palhaço, ai, ai

Vêm de carrerinho não

Dobre o joelho no chão

Esse carrerinho...

Dobre o joelho no chão, ai, ai, eh...

Pai nosso e ave Maria

Pai nosso rezar por devoção

Faz uma ave Maria
Pai nosso rezar por devoção, ai, ai, eh...

E ao nosso Pai cristão

Ele é o Rei do mundo

E ao nosso Pai cristão, ai, ai, eh...

Alevante pecador

Tira o joelho do chão

Alevante pecador

Pois tira o joelho do chão, ai, ai, eh...

Vai cumprir nosso dever, ai, ai

E a nossa obrigação, ai, ai

Vai cumprir nosso dever

E a nossa obrigação, ai, ai, eh...

Cada um põe sua deixa

Mas chega folião

Cada um põe sua deixa

Mas chega folião, ai, ai, eh...

Canto - 8

Meus amigos dá licença

E vou fazer deposição

Primeiro peço saúde

Pra todos que aqui estão

Primeiro peço saúde

Pra todos que aqui estão, ai, ai, eh...

Pro senhor e pra senhora

Ouvir,ei... preste atençã

O senhor e a senhora

Ouvir,ei... preste atenção, ai, ai, eh...

Em nome do Trêis Reis santo

Lhe pede o folião

Em nome dos Três Reis santo

Lhe pede o folião, ai, ai, eh...

Pra rezar o santo terço

Bendita refeição

Pra rezar o santo terço

Bendita refeição, ai, ai, eh...

Terminar nossa jornada

Encontrei uma intenção

Terminar nossa jornada

Encontrei uma intenção, ai, ai, eh

Lhe peço de novo a benção

Não vai arreparar

Lhe peço de novo a benção

Vai não vai arreparar, ai, ai, eh...

Intenção de Santos Reis

O que nos vamos rezar

Intenção dos Santos Reis, ai, ai, eh...

Nós vamos rezar, ai, ai, eh...

$\mathrm{E}$ depois da refeição

Retornaremo a cantar

$\mathrm{E}$ depois da refeição

Retornaremo a cantar , ai, ai, eh...

E agradecer oferta 
Quem quiser em lhe oferta

E agradecer a oferta

Quem quiser Ihe ofetar, ai, ai, eh...

Pra rezar Santo Reis

É hora de nóis parar

Pra rezar pra Santos Reis

É hora de nóis para, ai, ai, eh...

Vou fazer uma despedida

Pra todos que aqui estão

Vou fazer a despedida, ai, ai, eh...

Canto - 9

Cheia de graça

Senhor é bondoso

Bendita sois

Entre as mulheres

Bendito é o Fruto

Do vosso ventre

Nasceu Jesus

Santa Maria de Deus

Olhai a Deus por nós

Mãe dos pecadores

Agora e na hora

Da nossa morte

Amém Jesus

Maria, José

Viva São José

Da Virgem Maria

Viva ó Pai eterno

$E$ Jesus the guia

O dono da casa

Lhe dê alegria

Ele e a Bandeira

Pra toda a companhia

Anjos lá do céu

Cantam...

Na faltar na mesa

O pão de cada dia

Viva São José

Da Virgem Maria

Abençoado filho teu

da família amém

Canto - 10

Esse é o primeiro verso, ai, ai

Que eu canto nesse dia

Esse é o primeiro verso, ai, ai, eh...

Ai que eu canto nesse dia ai, ai, eh...

Viajando sobre...

Os foliões e companhia
Viajando na...

Ai os foliões e companhia, ai, ai, eh...

Nóis vem vindo de tão longe

Visitar sua família

Nóis vem vindo de tão longe

Ai visitar sua família, eh...

Dos meninos de Maria

Ai o Menino de Maria

Senhor dono da casa

Foi fazer filho estudar

Meu senhor dono da casa

Mas foi fazer filho estudar, ai, ai,

eh...

Por favor, acende a vela

Pra clareá a cantar

Por favor, acende a vela

Pra clareá noís a cantar, ai, ai, eh...

O silencio...

Tá feliz nesse momento

Está feliz nesse momento, ai, ai, eh...

Vamos cantar uma música

E falar do nascimento

Vamos cantar uma música

Ai e falar o nascimento, ai, ai, eh...

E o Menino foi nascido

Do mais puro coração

O Menino foi nascido

Ai do mais puro coração, ai, ai, eh...

Ai... a Virgem Maria

Ai... a Virgem Maria

O Menino foi nascido

De uma bela criatura

O Menino foi nascido

Ai de uma bela criatura, ai, ai, eh...

Os profetas escreveu ai

O que está nas escrituras

Os profetas escreveu

Ai o que ta nas escrituras, ai, ai, eh...

O senhor me dá licença

A cantoria vai parar

O senhor me dá licença

A cantoria vai para, ai, ai, eh...

Canto - 11

Venha cá o meu palhaço, ai, ai

Fazer sua obrigação

Venha cá o meu palhaço

Ai fazer sua obrigação, ai, ai, eh...

E cumprir o seu desejo

Da chegada os folião

Já cumpriu o seu desejo 
Ai da chegada os folião, ai, ai, eh...

Cada um com sua tarefa

Fazer nossa obrigação

Cada um com sua tarefa

Ai fazer nossa obrigação, ai, ai, eh...

Meu menino dá licença

Vamos estar em posição

O menino dá licença

Ai vamos fazer posição, ai, ai, eh...

Endireita... e ajuelha

Pra todos que aqui estão

Endireita..... e ajuelha

Ai pra todos que aqui estão, ai, ai, eh...

Meu senhor dono da casa

Por direito essa canção

Meu senhor dono da casa

Ai por direito essa canção, ai, ai, eh...

Os Três Reis lhe pede oferta

O que mandar seu coração

Os Três Reis lhe pede oferta

Ai o que mandar seu coração, ai, ai, eh...

Eu vou dar um cabrito!

Vamo agradecer a oferta

Dada de bom coração

Pra agradecer a oferta

Ai dada de bom coração, ai, ai, eh...

Pra ajudar na nossa festa

De oferta uma criação

Pra ajudar na nossa festa

Ai de oferta uma criação, ai, ai, eh...

Deus que ajude o senhor

$E$ toda a sua geração

Deus que ajude o senhor

Ai toda a sua geração, ai, ai, eh...

$E$ amém em Jesus Cristo

Deus lhe pague cidadão

Amém em Jesus Cristo

Ai Deus lhe pague cidadão, ai, ai, eh...

Eu vou dar um frango!

Vamo agradecer a oferta

Em louvor dessa senhora

Vamo agradece a oferta

Ai em louvor dessa senhora, ai, ai, eh...

Que oferta pros Três Reis

Canto pra ela agora
De oferta pros Três Reis

Ai canto pra ela agora, ai, ai, eh...

Os Três Reis que lhe acompanha

De dia e toda hora

Os Três Reis que lhe acompanha

Ai todo dia e toda hora, ai, ai, eh...

Vamo agradecer a oferta

Que foi dada nessa hora

Vamo agradecer a oferta

Ai que foi dada nessa hora, ai, ai,

eh...

Em louvor do nosso Pai

Em louvor do nosso Pai, ai, ai

Que foi embora, ai, ai, eh...

Nos deixou aqui na terra

Para morar no Reino da glória

Nos deixou aqui na terra

Ai mora no Reino da glória, ai, ai, eh...

Dê um beijo na bandeira

Que a hora já chegou

Dê um beijo na bandeira

Ai que a hora já chegou, ai, ai, eh...

Folião tá despedindo aia

Da senhora e do senhor

Folião ta despedindo

Aia da senhora e do senhor, ai, ai,

eh...

Que o senhor teja com vós

Ai... Por favor

Que o senhor esteja com vóz

Ai... por favor, ai, ai, eh...

Ele marco a presença

Que a família do senhor

Ele marcou a presença

Que a família do senhor, ai, ai, eh...

Vamo agradece oferta

Dada de bão coração

Vamo agradecê de coração

Ai dada de bão coração, ai, ai, eh...

Que louvou nossa bandeira

De sua explicação

Que louvou nossa bandeira

Ai de sua explicação, ai, ai, eh...

$E$ pediu que nois cantasse

Em nome da saudação

$E$ pediu que nois cantasse

Ai em nome da saudação, ai, ai, eh...

$\mathrm{O}$ perigo que passou

$\mathrm{O}$ da solidão

O perigo que passou, ai, ai, eh...

Ele foi internado, ai, ai

Mais em operação

Ele foi internado, ai, ai, 
Em nome da operação, ai, ai, eh...

Jesus cristo lá do céu

O senhor não sofre não

Jesus cristo lá do céu

Ai o senhor não sofre não, ai, ai, eh...

Ele vem embora pra casa

Com toda satisfação

Ele vem embora pra casa

Ai com toda satisfação, ai, ai, eh...

Canto - 12

Veja aqui hora são essas

Que os Três Reis apareceu

Veja qui hora são essas

Ai que os Três Reis apareceu, ai, ai, eh...

Viajando desde cedo

Longe percorreu

Viajando desde cedo

Ai longe percorreu, ai, ai, eh...

Essa chegada foi tão linda

Que o senhor arrecebeu

Essa chegada foi tão linda

Ai que o senhor arrecebeu, ai, ai, eh...

Inté a porta do céu abriu

O Anjos do céu desceu

Inté a porta do céu se abriu

Ai os Anjos do céu desceu, ai, ai, eh...

Nóis viemo visitar

Pra trazer a benção de Deus

Nóis viemo visitar

Ai pra trazer a benção de Deus,

ai, ai, eh...

Vim pedir a sua oferta

O que mandar seu coração

Vim pedir a sua oferta

Ai que mandar seu coração, ai, ai, eh...

Nessa hora de alegria

Nessa hora de alegria

Viva no céu e na terra

Viva no céu e na terra, ai, ai, eh...

Pra abençoar os Santos Reis

Que atraiu a decisão

Pra abençoar os Santos Reis

Ai que atraiu a decisão, ai, ai, eh...

No dia do aniversário

Santos Reis manda benção

No dia do aniversário
Ai Santos Reis manda benção, ai, ai, eh...

Esse dia é tão lindo

De oferta de criação

Esse dia é tão lindo

Ai de oferta de criação, ai, ai, eh...

Fez jurar pro Santos Reis

Pra cumprir sua intenção

Fez jurar pro Santos Reis

Ai pra cumprir sua intenção, ai, ai, eh...

Abençoai o seu pomar

Toda sua plantação

Abençoai o seu pomar

Ai toda sua plantação, ai, ai, eh...

Santos Reis vai abençoar

O São Sebastião

Santos Reis vai abençoar

Ai ó São Sebastião, ai, ai, eh...

Nóis recebe a boa sorte

Do bendito Santo bão

Nóis recebe a boa sorte

Ai do bendito Santo bão, ai, ai, eh...

Pra ajuda na nossa festa

Pra faze um grande festão

Pra ajuda na nossa festa

Ai pra fazê um grande festão, ai, ai, eh...

E também esse povão

Ai também esse povão, ai, ai, eh...

Viva no céu e na terra

Nessa hora de alegria

Viva no céu e na terra

Ai nessa hora alegria, ai, ai, eh...

Oi... folião

Ta fazendo a cantoria

Oi... folião

Ai ta fazendo a cantoria, ai, ai, eh...

Os Três Reis da benção

Pra cantar o resto do dia

Os Três Reis dá benção

Ai pra cantar o resto do dia, ai, ai, eh...

Nóis estamo agradecendo

A bonita melodia

Nóis estamo agradecendo

A bonita melodia

Ao nóis estamo agradecendo, ai, ai, eh...

Santos Reis dá benção

Pro senhor e pra sua família

Santos Reis dá benção

Ai pro senhor e pra sua família, ai, ai, eh...

Em nome de Santos Reis 
Você deu a decisão

Em nome dos Santos Reis

Ai você deu a decisão, ai, ai, eh...

Hei...Três Reis santos

Que vai dar a direçãoh

Hei... Três Reis santos

Ai que vai dar a direção, ai, ai, eh...

Hei... O menino Deus

De toda contradição

Hei... O menino Deus

Ai de toda contradição, ai, ai eh...

Santos Reis Ihe abençoa

Com amor no coração

Santos Reis lhe abençoa

Ai com amor no coração, ai, ai, eh...

Segurou esta bandeira

Na sua mão

Segurou esta bandeira

Ai na sua mão, ai, ai, eh...

Com o lenço no pescoço

Pra ganhar a proteção

Com o lenço no pescoço

Ai pra ganhar a proteção, ai, ai, eh...

Vou pegar na sua mãos, ai, ai

Na nossa despedida, oia, oia

Santos Reis já vai embora, oia, oia

Pra nossa festa, oia, oia

Vocês fica aí com Deus, oia, oia

Os Três Reis já vai seguir, oia, oia

Quando for o ano que vem, oia,

oia

De novo nóis vorta aqui, oia, oia

Dê um beijo na bandeira, oia, oia

Ela agora vai sair, oia, oia

Ai Dê uma salva de rojão, ai, ai, eh...

Em nome de Santos Reis

E de todo folião

Em nome de Santos Reis

Ai de todo folião, ai, ai, eh...

Eu vou fazer um pedido

O senhor presta atenção

Vou fazer um pedido

Ai o senhor presta atenção, ai, ai, eh...

Vou pedir licença

Pra chegar no seu terreiro

Vou pedir licença

Ai pra chegar no seu terreiro, ai, ai, eh...
Leva a bandeira na frente

Pra chegada ao folião

Leva a bandeira na frente

Ai pra chegada ao folião, ai, ai, eh...

Encontrou Jesus Menino

E a Virgem Imaculada

Encontrou Jesus Menino

Ai e a Virgem Imaculada, ai, ai, eh...

E agora Menino seu

Da Virgem Maria

Agora Menino seu

Ai da Virgem Maria, ai, ai, eh...

E o Menino foi nascido

Lá em Belém, Judá

E o Menino foi nascido

Ai em Belém, Judá, ai, ai, eh...

Nasceu pobre, peregrino

Tentando se salvar

Nasceu pobre, peregrino

Tentando se salvar

Ai nasceu pobre peregrino, ai, ai, eh...

Agora nesse momento

Os Três Reis ficou contente

Agora nesse momento

Os Três Reis ficou contente

Ai agora nesse momento, ai, ai, eh...

Chegamos cantando a música

$E$ falar do nascimento

Chegamos cantando a música

Ai e falar do nascimento, ai, ai, eh...

Viva a Nossa Senhora

E o nosso celestiá

Viva a Nossa Senhora

Ai e o nosso celestiá, ai, ai, eh...

Pra falar a profecia

Cantoria vou parar

Pra falar a profecia

Ai, cantoria vou parar, ai, ai, eh...

O Rubinho apreparado

Pra falar no meu lugar

O Rubinho apreparado

Ai pra falar no meu lugar, ai, ai, eh...

Canto - 13

Vem trazer muita saúde

Paz senhor, e alegria

Ai meu Deus paz

Pra toda minha família, ai, ai, eh...

Ele que vem do Oriente pra nos abençoai

Ai,ai, meu Deus abençoai

Traz saúde, fé, oferta

Pra nossa festa ajuda

Ai ai, meu Deus 
Pra nossa festa ajuda eh...

Ai,ai, meu Deus

$\mathrm{Ai}$, vamo agradecer a oferta

Dada de bão coração

Ai,ai, meu Deus

Dada de bão coração

Pra vender sua porcada

Os Anjos desceu no chão

$\mathrm{Ai}$, ai, meu Deus

Os Anjo desceu no chão

Acompanhando Deus da criação

$\mathrm{Ai}$,ai, meu Deus

Da criação, eh...

Também a família

Dê a senhora abençoada

Com esta bandeira na mão, oi, ai

Ai,ai, meu Deus com a bandeira

na mão

Já começa a diversão

$\mathrm{Ai}$,ai, meu Deus

Já começa a diversão

Deus abençoa a senhora

$\mathrm{Ai}$, ai, meu Deus

Companhia vai embora

Santos Reis vai viajar, oi, ai,

$\mathrm{Ai}$, ai, meu Deus

Santos Reis vai viajar

Vamo indo...

Passa pra e convidar, oi, ai,

$\mathrm{Ai}$, ai, meu Deus

Passa pra e convidar

$\mathrm{Ai}$, ai, meu Deus

Abençoa o vosso lar

$\mathrm{Ai}$,ai, meu Deus

Paz, saúde pra vocês

Aa,ia meu Deus

Abençoa o vosso lar, ai, ai

Com todo seu pessoá

$\mathrm{Ai}$, ai, meu Deus

Com todo seu pessoá

Deixamos nosso convite

Para junto festejar, ai, ai

$\mathrm{Ai}$,ai, meu Deus

Para junto festejar, ai, ai

Ai... Aqui senhor

Nessa hora de benção

Ai nessa hora de benção, ai, ai, eh...

Fico alegre e satisfeito

Encontro o folião

Muito alegre e satisfeito

$\mathrm{Ai}$, ai, encontrou o folião, ai, ai, eh...

E abraçou os Santos Reis, ai, ai Uma salva de rojão
Abraçou o Santos Reis

Ai, ai, uma salva de rojão, ai, ai, eh...

Os Três Reis do oriente ai, ai

Também pede permissão

Os Três Reis do oriente, ai, ai

$\mathrm{Ai}$, ai também pede permissão, ai, ai, eh...

Caminhamos cidadão

Ai, ai, caminhamos folião, ai, ai, eh...

Os Três Reis

Pra vocês um ano bão

Os Três Reis

Ai, ai, ai, pra vocês um ano bão

Com licença minha senhora

Pra entrar nesse portão

Com licença minha senhora

Pra entrar nesse portão, ai, ai, eh...

A licença está tirada

Entra, entra, folião

A licença está tirada

Entra, entra folião, ai, ai, eh...

Os Três Reis fica contente

Nesta vida cidadão

Os Três Reis fica contente, ai, ai, eh...

Nóis viemos por notícia ai

Do bondoso coração

Nóis viemos por noticia

Mais o bondoso coração, ai, ai, eh...

$\mathrm{Na}$ casa que o senhor mora

É ponto de recepção

$\mathrm{Na}$ casa que o senhor mora

Mai é ponto de recepção, ai, ai, eh...

Todo o ano o senhor ai

Alimenta o folião

Todo ano o senhor ai

Ai alimenta o cidadão, ai, ai, eh...

Meu senhor dono da casa

Que vive nesse lar

Meu senhor dono da casa

Ai que vive nesse lar, eh...

Folião estão cantando ai

Precisamo lhe cantar

Folião estão cantando

Ai precisamos lhe cantar, ai, ai, eh...

E se for de vosso gosto, ai, ai

Você também pode cantar

E se for do vosso gosto ai

Ai cê pode cantá, ai, ai, eh...

$E$ os nossos instrumentos

Por favor venha buscar

$E$ os nossos instrumentos

Ai, por favor venha buscar, ai, ai, eh...

$\mathrm{E}$ depois da refeição 
Nóis retornaremo cantar

$E$ depois da refeição aia

Ai nóis retorneremo a cantar, ai, ai, eh...

Os Três Reis vai vir

Nessa hora de benção

Os Três Reis vai vir...

Ai nessa hora de benção, ai, ai, eh...

Veio Ihe fazer visita ai

$E$ também uma oração

Veio Ihe fazer visita ai

Ai também uma oração, ai, ai, eh...

Ele vem pedir oferta

O que mandar seu coração

Ele vem pedir oferta

Ai o que mandar seu coração, ai, ai, eh...

Eu vou dar um leitão

Vamo lhe agradecer a oferta

Dada de bão coração

Vamo agradecer a oferta

$\mathrm{Ai}$, dada de bão coração, ai, ai, eh...

Pra ajudar na nossa festa

De oferta uma criação

Pra ajuda na nossa festa

$\mathrm{Ai}$, de oferta uma criação, ai, ai, eh...

Nois vai cantar em louvor

Pela sua geração

Nois vai cantar em seu louvor

Ai pela sua geração, ai, ai, eh...

Um frango da madrinha!

Vamo agradecê a oferta

Num momento

Vamo agrade a oferta

Nóis estamo agradecendo

Em nome do padroeiro

Nóis estamo agradecendo

Ai em nome do padroeiro, ai, ai, eh...

Mais um frango da madrinha!

Tenha fé nos Santos Reis ai

A bandeira tem virtude

Tenha fé nos Santos Reis

Ai, a bandeira tem virtude, ai, ai, eh...

Em louvor da juventude

Deus lhe dê muita saúde

Durante a sua vida

Deus lhe dê muita saúde

Ai durante a sua vida, ai, ai, eh...
Canto - 14

Os Três Reis que aqui chegaram

Nesta hora de alegria ai, ai

Nesta hora de alegria, ai, ai, eh...

Vim fazer uma visita

Pra senhora e pra família ai

Pra senhora e pra família, ai, ai, eh...

Também vim lhe pedir oferta

E o desejo pro seu dia ai, ai

O desejo pro seu dia, ai, ai, eh...

Eu vou dar um bezerro!

Vamo agradece a oferta

Dada de bão coração ai

Dada de bão coração, ai, ai, eh...

Em louvor desta senhora

Que está com os Três Reis na mão

ai

Que está com os Três Reis na mão,

ai, ai, eh...

$E$ também os seus dois filhos

Que tem muita estimação ai

Que tem muita estimação, ai, ai, eh...

Pra ajudar na nossa festa ai

Deu oferta uma criação ai

Deu oferta uma criação, ai, ai, eh...

Os Três Reis lhe faz promessa ai

O senhor veio chegando

Disse adeus ao folião ai

Disse adeus ao folião, ai, ai, eh...

Deu um beijo na bandeira

E abraçou de coração ai

E abraçou de coração, ai, ai, eh...

Em nome do Santos Reis

Jesus cristo daí benção ai

Jesus cristo daí benção, ai, ai, eh...

Com todo seus folião

Com todo seus folião

oi lá.....

Santo Reis vem chegando

Santos Reis vem chegando, ai, ai,

eh...

Pra encontra essa família

Pra encontra essa família

oi lá....

Chega mais gente cantando

Chega mais gente cantando

Olé, ola, olará,

Vem trazer saúde e sorte

Vem trazer saúde e sorte

oi lá...

Vem pra dar um bão novo ano

Pra dar um bão novo ano

Olé, ola, olará,

E pra ajuda fazer a festa 
Pra ajudar fazer a festa

Olé, ola, olará,

Oferta tamo juntando

Oferta tamo juntando

Olé, ola, olará,

Vamo agradece a oferta

Vamo agradece a oferta

Que sempre ajudaram

Que sempre ajudaram

Olé, ola, olará,

Ele vem do Oriente

Ele vem do Oriente

Olé, ola, olará,

Todo ocêis abençoai

Todo ocêis abençoai

Olé, ola, olará,

Vou dar 30,00 de oferta em

dinheiro!

Por vontade da senhora

Por vontade da senhora

Olé, ola, olará,

A Juliá mandou cantar

A Juliá mandou cantar

Olé, ola, olará,

O divino Espírito Santo

O divino Espírito Santo

Olé, ola, olará,

A família abençoai

A família abençoai

Olé, ola, olará,

A benção de Nossa Sonhara

Benção de Nossa Senhora

Olé, ola, olará,

10,00

Por conta desse casal

Por conta desse casal

Olé, ola, olará,

Pra vocês vamo cantar

Olé, ola, olará,

Pra família abençoai

Pra família abençoai

Olé, ola, olará,

Abençoa o presente

Abençoa o presente

Olé, ola, olará,

Por conta de uma família

Por conta de uma família

Olé, ola, olará,

Em seu louvor vamo cantar

Em seu louvor vamo cantar

Olé, ola, olará,

Nossa Senhora Aparecida

Nossa Senhora Aparecida
Olé, ola, olará,

Ela vai te abençoar

Ela vai te abençoar

Olé, ola, olará,

Em nome do Santo Rei

Em nome do Santo Rei

Olé, ola, olará,

A saúde vai deixar

A saúde vai deixar

Olé, ola, olará,

Que vocês sejam felizes

Que vocês sejam felizes

Olé, ola, olará,

É o que vamo desejar

É o que vamo desejar

Olé, ola, olará,

20,00 pra mim, pro meu marido e

pro meu filho

Pra senhora e seu marido

Pra senhora e seu marido

Olé, ola, olará,

De novo vamos cantar

De novo vamos cantar

Olé, ola, olará,

E pede pro seu filhinho

E pede pro seu filhinho

Olé, ola, olará,

Pro Santos Reis abençoar

Pro Santo Reis abençoar

Olé, ola, olará,

Por conta dessa família

Por conta dessa família

Olé, ola, olará,

Santos Reis a abençoa

Santos Reis a abençoa

Olé, ola, olará,

Nossa Senhora Aparecida

Nossa Senhora Aparecida

Olé, ola, olará,

Dê saúde e proteção

Dê saúde e proteção

Olé, ola, olará,

Vem os Anjos perulando

Vem os Anjos perulando

Olé, ola, olará,

Um pacote de macarrão, 1 litro de

óleo e um kilo de sal

Mas que senhora abençoada

Que senhora abençoada

Olé, ola, olará,

Tá com essa bandeira na mão

Tá com essa bandeira na mão

Olé, ola, olará,

Mas os Três Reis do Oriente

Os Três Reis do Oriente 
Olé, ola, olará,

Tão coberto de benção

Tão coberto de benção

Olé, ola, olará,

Dê um beijo na bandeira

Dê um beijo na bandeira

Olé, ola, olará,

Ela vai se arretirá

Ela vai se arretirá

Olé, ola, olará,

Vai aceitá um convite

Vai aceitá um convite

Olé, ola, olará,

Ele vai Ihe convidar

Ele vai lhe convidar

Olé, ola, olará,

Santos Reis já se despede

Santo Reis já se despede

Olé, ola, olará,

Deixando...

Os cidadão tão convidado

Os cidadão tão convidado

Pra vocês acompanhar

Pra vocês acompanhar

Olé, ola, olará,

Mais veja que horas são essas, oi, ai,

Que Santos Reis apareceu, oi, ai,

Que Santos Reis apareceu, ai, ai eh...

Vai visitando a região

Um monte de terras percorreu

Vai visitando a região, ai, ai eh...

Ai esse encontro tão bonito

Que o senhor arrecebeu

$\mathrm{Oi}$, ai, que o senhor arrecebeu, ai, ai eh...

E a porta do céu abriu

Os Anjo do céu desceu
Ai os Anjos do céu desceu, ai, ai eh...

As roseira floreceu

As roseira floreceu, ai, ai eh...

Ai nóis viemo em sua casa

Pra trazer a benção de Deus

Ai pra trazer a benção de Deus, ai, ai eh...

Ai Santos Reis lhe pede oferta

O que mandar o coração seu

O que mandar o coração seu, ai, ai eh...

Agradece a oferta

Quantia de 10 real

Ai quantia de 10 real, ai, ai eh...

A senhora e sua esposa

Representam um grande pessoal

Representam um grande pessoal, ai, ai eh...

Ai Santos Reis lhe dá a benção

Do nosso pai celestial

Ai do nosso pai celestial, ai, ai eh...

Ai vai ganhar um ano novo

Como ganhou o Natal

Ai como ganhou o Natal, eh...

Canto - 15

Noís vamos começa a cantar

Nois vamos começa a canta, ai, ai eh...

Vou saudar a todos...

Vamos saudar o prefeito

Que veio nos prestigiar

Ai veio nos prestigiar, ai, ai eh...

E o Bispo também

$A i$ veio à missa rezar

Ai veio à missa rezar, ai, ai eh...

Vou saudar nossa família

Ai que veio se apresentar

Ai que veio se apresentar, ai, ai eh...

Vou saudar as autoridades 


\section{ANEXO B - Coroação de um Rei Negro}

A Coroação de um Rei Negro em 1748

Em 1742, fundou-se no campo de São Domingos a Capela de Nossa Senhora da Lampadosa, sendo bispo do Rio de Janeiro D. Fr. Antônio do Desterro.

O terreno para a fundação foi cedido pelo Senado da Câmara à irmandade da mesma Senhora, que, por funcionar no Rosário, isso requere e obteve. sobre pedra.

Do primitivo templo, bem raras são as relíquias; quase que não existem pedra

Como preciosidades históricas há a imagem da excelsa padroeira, a do Santo Rei Baltazar, um Apóstolo do Mestre Valentim, e um admirável retrato a óleo do Marquês de Pombal, obra-prima da arte antiga.

O mais o vandalismo destruiu...

A lendária capela, como todo o Brasil nos felizes tempos da colônia, teve seus dias cor-de-rosa, suas glórias no apogeu.

Não obstante serem as irmandades possuidoras do velho tempo compostas de negros d' África e crioulos, na maior parte escravos, o ledor de traçadas crônicas ainda pode descobrir, no pouco que existe de seu arquivo - que nos foi franqueado pelo inteligente, zeloso e atual ecônomo, o Sr. José Rodrigues da Costa Soares, que salvou e o conserva, vestígios de seu esplendor de outrora, de uma grandeza extinta.

Dentre as petições existentes em manuscritos originais, algumas referentes ao nosso motivo, depara-se a seguinte que, com as demais, nos serviram de facho sideral, que levantaremos para caminhar na escuridão do passado.

Aos seus luares tépidos e ao respirar agonizante da tradição oral, vejamos desfilar a turba negra que extravazava no templo e fremia no campo São Domingos e na cidade, antecipando-se à festa e celebrando-a condigna.

O documento, ei-lo:

"II. ${ }^{\text {mo }}$ e Ex. ${ }^{\text {mo }}$ Sr. Desembargador Ouvidor Geral do Crime: - Dizem o Imperador, o Rei, a Rainha e mais adeptos da nação do Santo Rei Baltazar, que eles costumam, em os domingos e dias santos festivos, tirar as suas esmolas por meio de danças e brinquedos que fazem com todo o recato e sossego, sem inquietação e perturbação alguma como é notório, cujas esmolas são aplicadas com o necessário às festividades do Santo Rei: e porque do mesmo modo têm alcançado do Ex.mo Sr. Conde Vice-Rei, como se vê no documento junto, e como querem também a concessão de $V$. Ex. ${ }^{a}$ para o mesmo fim acima descrito, e assim também querem no dia dos Reis próximo coroar para rei da nação Rebolo a Antônio, fâmulo do mesmo II. ${ }^{\text {mo }}$ e Ex. ${ }^{\text {mo }}$ Sr. Conde Vice-Rei, e que nesse dia pretendem sair com seus instrumentos e danças da mesma nação, para ser feito com maior obséquio e dançar - pelo que pedem, etc."

Datada de 3 de dezembro de 1748, a esta petição, seguida das assinaturas em cruz dos requerentes, acompanha favorável despaço, e a Irmandade do Santo Rei Baltasar entregava-se ao gozo preparativo da licença do magistrado.

E pelas ruas, pela cidade, internando-se nas fazendas do Engenho Velho, do Engenho Novo, do Macaco, de Santa Cruz, nos limites da autorização concedida, levas de pretos, dançando e cantando, rufavam caixas de guerra, tangiam instrumentos músicos de seus climas natalícios, recebendo esmolas profusas, dádivas valiosas, que entravam para 0 cofre da irmandade, por conta da qual corria a despesa da festa.

A esses bandos tumultuários, a esses homens esculturais, nus da cintura para cima, de rosto deformado ou tatuado, segundo os estilos de suas nações, sucediam-se avultadas turmas de outros negros, de mulheres e crianças de diversas tribos, que se associavam a alheios prazeres. 
E os foliões africanos, de calça e suspensórios, de fachas encarnadas e azuis a tiracolo, com a cabeça adornada de penas e o peito listrado de tiras vistosas, tamborilavam em seus tamborins de dança, faziam evoluções com a perna no ar, cantavam suas cantigas bárbaras, que repercutiam avolumadas ou esvaecidas, na proporção das distâncias.

Enquanto essas levas ambulantes amontoavam o cabedal para o régio festejo de seus maiorais, na Capela da Lampadosa erigia-se o trono para a coroação, armava-se o altar do santo Rei Mago, assentava-se uma pequena varanda para o séqüito real, ficando para a véspera de Reis o cuidado da capinagem do terreno fronteiro à igreja, que amanhecia limpo, coberto de areia finíssima, esmaltado de folhas e flores, para bailados e comemorações externas do monarca eleito.

Apenas amanhecia o Dia de Reis, o campo de São Domingos, nas proximidades da capela, opulentava-se de um espetáculo variado e estranho em que Moçambiques, Cabundás, Benguelas, Rebolos, Congos, Cassanges, Minas, a pluralidade finalmente dos representantes de nações d' África, escravos no Brasil, exibiam-se autênticos, cada qual com seu característico diferencial, seu tipo próprio, sua estética privativa.

Homens, mulheres, e crianças, em largo regozito a liberdade de um dia, esqueciam por intantes as palmeiras de sua terra, os fetiches de seus país, aguardando a cerimônia da coroação do soberano, e rendendo culto ao santo Rei Baltasar, que Ihes recordava, pela cor que tinha, a cor de sua pele e de seu destino.

E o capelão da Lampadosa, percorrendo com vista a igreja pomposamente adereçada, dirigia-se à sacristia, tomava o Compromisso da Irmandade, lavrando os termos que deviam ser autenticados pelo Rei e pela Rainha na terminação do ato.

Quase às dez horas acendiam-se os altares, o capelão revestia-se, os sinos repicavam, e os irmãos do Santo Rei Baltasar, com suas opas de seda, esperavam no corpo da igreja, dobrando língua, batendo boca entre si.

Em breve, a vozeria confusa que se escutava lá fora, calava-se; os sinos repicavam mais vibrantes e rápidos, produzindo esta mudança do efeito o rolar surdo das caixas de guerra, o som de rapa das macumbas em grande número, a queda sonoramente uniforme dos chocalhos enfeitados da bárbara marcha precedendo o préstito.

De braços erguidos, pulando e revirando sobre as mãos, vestidos de penas e estofos coloridos, quatro muanas (negrinhos) serviam de batedores ágeis, fazendo negaças, cantando, gritando...

Atrás da música caminhavam majestosamente e Neuvangue (rei), a Nembanda (rainha), os Manafundos (príncipe), o Endoque (feiticheiro), os Uantuafunos (escravos, vassalos e vassalos do rei), luzido e vigoroso grupo daquelas festas tradicionais e genuinamente africanas, celebradas no Rio de Janeiro no século passado.

O Rei e a Rainha, com seus mantos de belbutina escarlate recamados de estrelas, com suas vestiduras cintilantes de lentejoulas e agaloadas, aquele com seu cetro dourado, e está com seu diadema resplandecente, pisavam garbosos à frente de sua corte, levando dois vassalos a duas coroas, vestido de capa e espada, ostentando na cabeleira carapinhada e no pontudo topete fios de corais e miçanga, que lhes desciam em volta como um casco de capacete.

Ao feiticeiro, enrolando e desenrolando em torno do pescoço enorme cobra, envergando vestimentas de peles e rubro cocar, olhando misteriosamente, volteavam-lhes 0 antebraço e o colo fieiras de miçangas e de pequenos búzios, entremeadas de figas e talismãs de rosário e bentinhos.

A turba-multa que os acompanhava fechava o magno cortejo, do qual somente o Rei, a Rainha, os príncipes e os vassalos entravam, sendo aqueles para serem coroados na Igreja.

Uma vez entronizados, o capelão, que os recebia à porta do templo, coroava-os ritualmente, conduzindo-os depois à sacristia, onde ouviam ler, marcavam em cruz e assinavam o documento oficial da coroação.

Do mesmo arquivo da Lampadosa, no citado Compromisso da Irmandade do Santo Rei Baltasar, encontrava-se entre muitos, este termo, que reproduzimos e que demonstra que 
na referida capela esses costumes conservaram-se até muito mais tarde, como pode ser verificado:

"Termo de coroação do Rei e da Rainha de nação Cabundá. - Aos seis dias do mês de outubro de 1811, neste Capela de Nossa Senhora da Lampadosa, tiveram posse e se coroaram de Rei, Caetano Lopes dos Santos, e de Rainha, Maria Joaquina, ambos de Nação Cabundá, por estarem eleitos pela sua nação e por terem licença do II. ${ }^{\text {mo }}$ Sr. Intendente Geral de Policia, e para constar-se se Ihes mandou passar este termo, no dia, mês e ano acima declarado. - Padre Tomás Joaquim de Melo, capelão da irmandade"

Seguiam-se sinais ou assinaturas dos reis coroados e de outros de diversas nações que testemunharam o ato.

Reatando a descrição interrompida por este curioso autógrafo, tratando dos tradicionais festejos de 1748, asseguramos que o quadro era completo, a cena pitoresca e nativamente instrumentada.

Concluída a solenidade religiosa, o Rei, a Rainha e os demais figurantes vinham incorporar-se ao séqüito deixado; e perdendo-se no dilatado campo de São Domingos, arrastavam após a si a massa popular, atraída pela música estridente, pela balancear aéreo e variado de surpresas dos muanas, que tanto realce davam nas avançadas do majestático préstito.

Á tarde, com a assistência dos régios personagem da manhã, havia as festas públicas comemorativas, os clássicos batuques realizados por negros de diferentes tribos, tendo como teatro o areal de improviso preparado na frente do templo, formando um quadrilátero guarnecido por semicírculos de folhagens, que pendiam do alto de bambus fincados.

Esta segunda festa era mais concorrida e popular; os negros das fazendas dos jesuítas, os escravos das casas fidalgas, alcançando para isso consentimento, avultavam aos bandos, no campo de São Domingos, em alegre algazarra, postando-se nas imediações do amplo quadrado, os rufos das caixas de guerras batidas ao longe.

Esquisitos no trajar, no semblante, nos gestos, negras e negros novos irrompiam de dada lado, entregues à obediência de seus chefes, à vigilância nunca iludida da polícia, que os espreitava.

E os pandeiros, os tambores, as macumbas, os canzás, as marimbas, precedendo a multidão, anunciavam estrugindo a entrada triunfal dos Congos nos festejos profanos da coroação de um Rei negro.

Da capelinha, de portas fechadas, o capelão à janela recreava-se do selvagem espetáculo, e os negros de nação, em pleno dia de Reis, julgavam-se venturosos de sua sorte, esquecendo-se dos desertos de sua terra e das travessias do mar. 
ANEXO C - Cópias de Documentos do Arquivo de José Nazareno Mimessi

- CEDAP, Assis/SP 